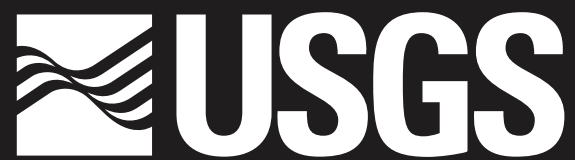

U.S. Geological Survey Actintices Related to American lindians and Alaska Natives

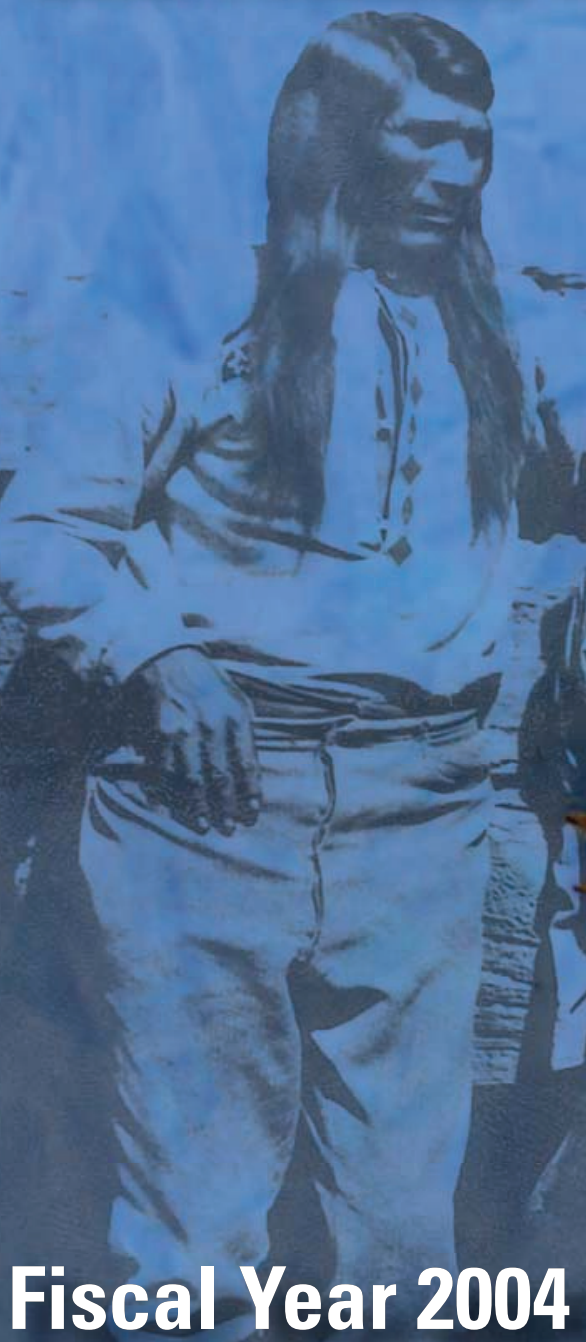

Circular 1296 


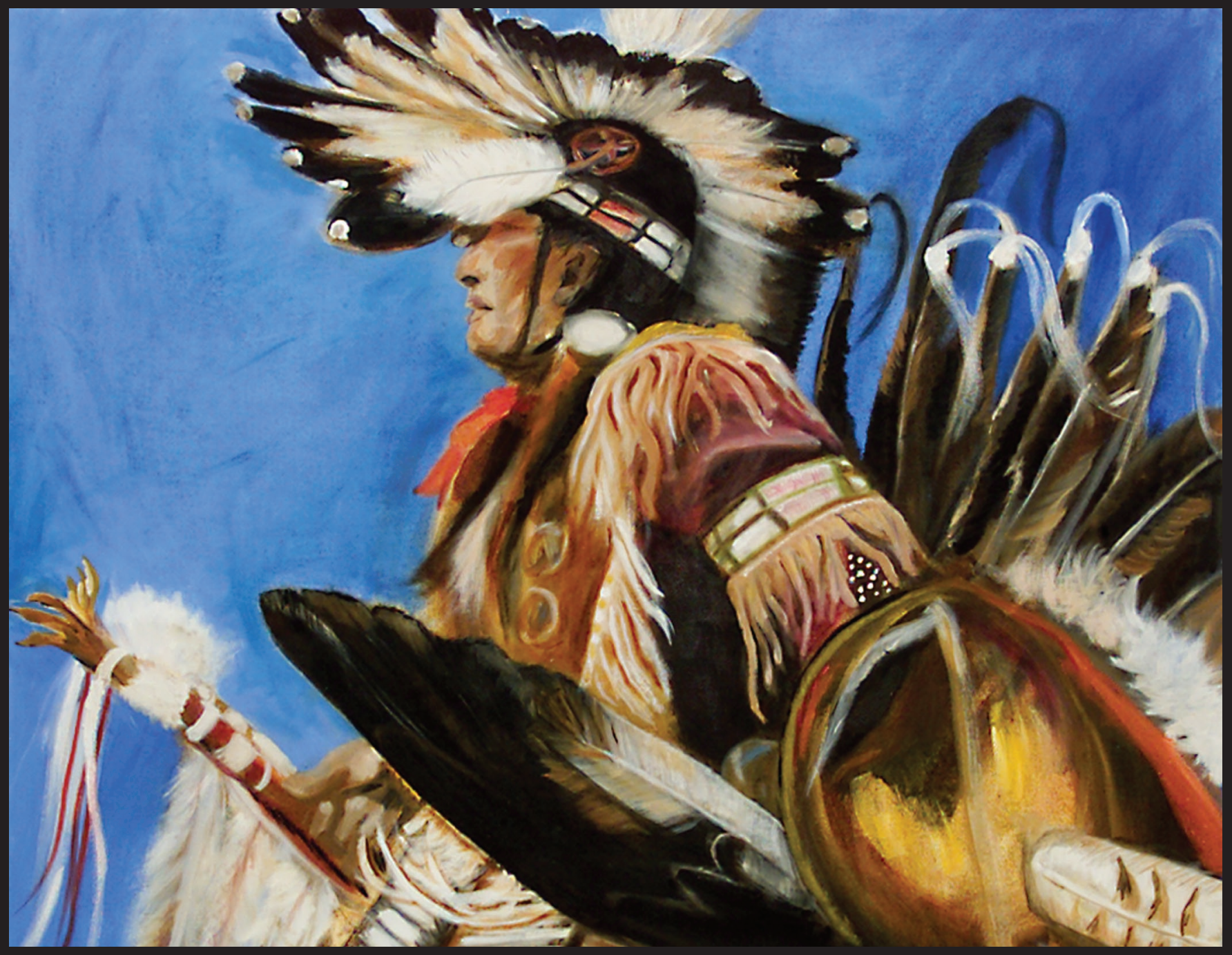

(Cover) "Lakota Dancer" artwork by Regina One Star, Sicangu (Rosebud) Lakota. Historical photograph shows Tau-gu, a Chief of the Paiute Indians, and Major John Wesley Powell, second Director of the U.S. Geological Survey, in southern Utah, about 1870. Powell was a great friend of Native Americans, working tirelessly for their fair treatment and on their behalf. During the 1860s, he led scientific explorations throughout Colorado and climbed both Pikes Peak and Longs Peak. He grew up in an abolitionist family, and he was a Civil War veteran, college professor, and Director of the U.S. Geological Survey for 3 years. USGS Photographic Library; date and photographer unknown. 


\section{U.S. Geological Survey Activities Related to American Indians and Alaska Natives}

Fiscal Year 2004

Circular 1296 


\section{U.S. Department of the Interior \\ P. Lynn Scarlett, Acting Secretary}

\section{U.S. Geological Survey \\ P. Patrick Leahy, Acting Director}

U.S. Geological Survey, Reston, Virginia: 2006

For product and ordering information:

World Wide Web: http://www.usgs.gov/pubprod

Telephone: 1-888-ASK-USGS

For more information on the USGS--the Federal source for science about the Earth, its natural and living resources, natural hazards, and the environment:

World Wide Web: http://www.usgs.gov

Telephone: 1-888-ASK-USGS

Any use of trade, product, or firm names is for descriptive purposes only and does not imply endorsement by the U.S. Government.

Although this report is in the public domain, permission must be secured from the individual copyright owners to reproduce any copyrighted materials contained within this report. 


\section{Contents}

List of Tribes or Tribal Governments Mentioned in the Report

Organizations or Events Related to American Indians or Alaska Natives

Mentioned in the Report

States Mentioned in the Report

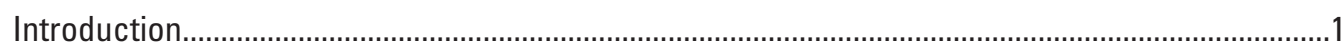

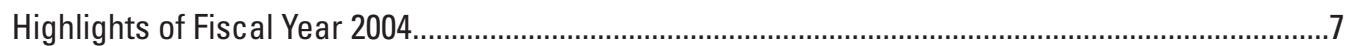

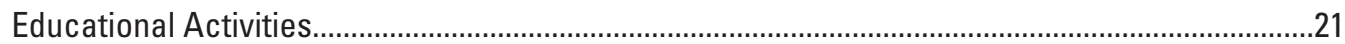

Resource and Environmental Activities .........................................................................................3

Technical Assistance ...................................................................................................................93

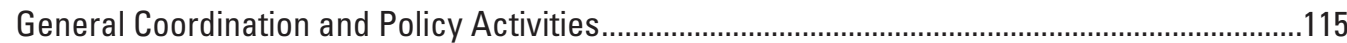

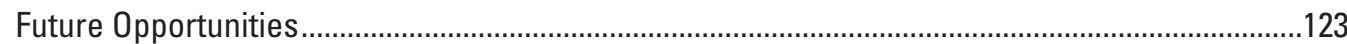

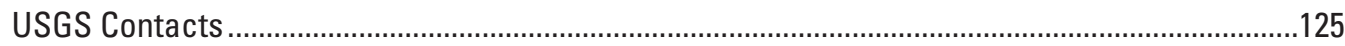

\section{Figures}

Map of USGS FY 2004 Activities on American Indian and Alaska Native Lands .iv

\section{Tables}

1. Fires mapped by USGS EROS for DOI Emergency Response Burn Severity Mapping Project, FY 2004

Tables showing water and sediment monitoring stations

This report is organized in the following manner: east to west, north to south. General information is followed by information on work in the northeastern United States; information about Alaska is at the end of each section. V

(1)

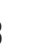
3 5 25 


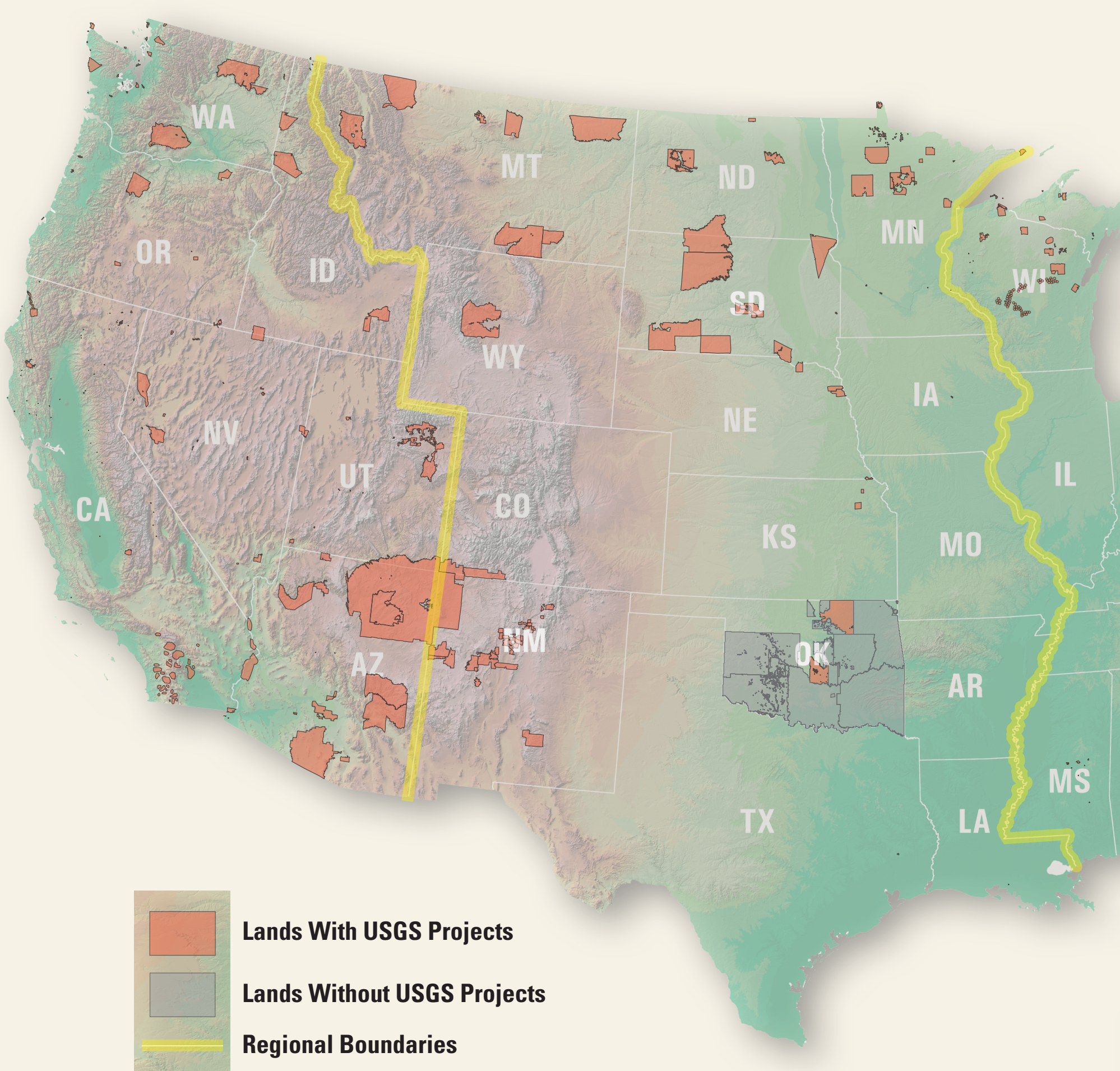




\section{Activities on American Indian and Alaska Native Lands}

\section{U.S. Geological Survey}

Fiscal Year 2004

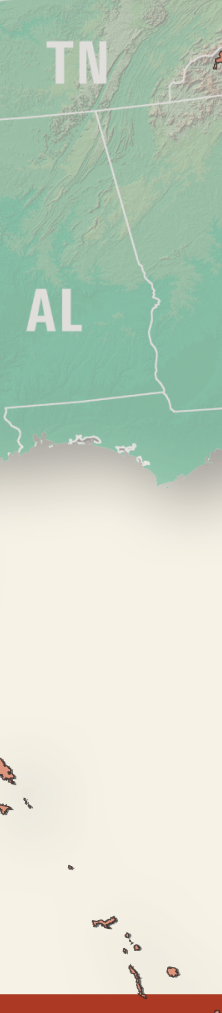




\section{List of Tribes or Tribal Governments Mentioned in the Report}

Names in this report are the most accurate that could be readily determined from several sources. Any inaccuracies are unintentional. Corrections are welcome and may be submitted to Susan Marcus (U.S. Geological Survey National Center, MS 104, 12201 Sunrise Valley Dr., Reston, Virginia 20192; 703-648-4437; fax 703-648-5470; smarcus@ usgs.gov)

\section{Tribal Name}

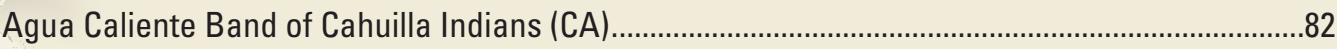

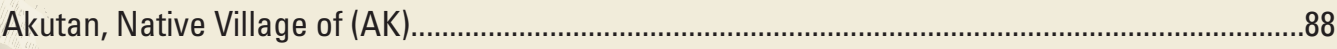

Arikara Tribe (see Three Affiliated Tribes) (ND) ………..............................................................108

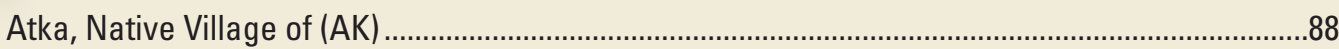

Bad River Band of Lake Superior Chippewa Indians (WI) .............................................37, 38, 108

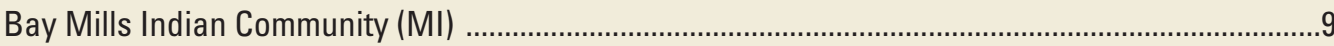

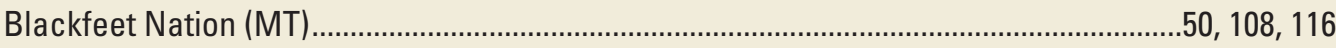

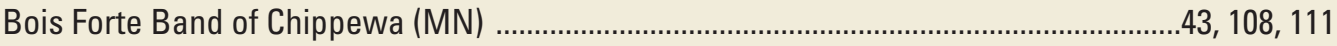

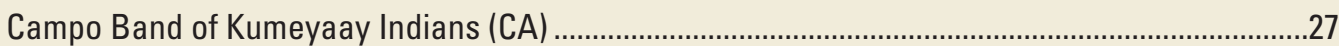

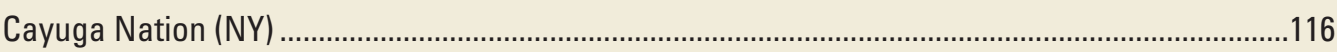

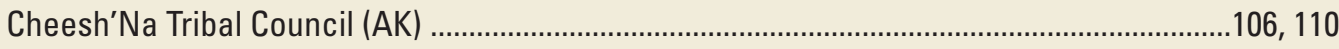

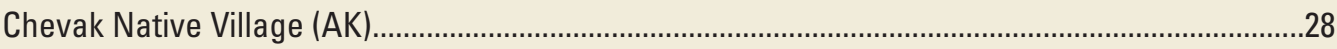

Cheyenne River Sioux Tribe (SD) .........................................................................................

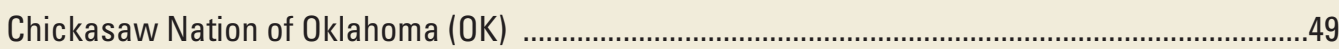

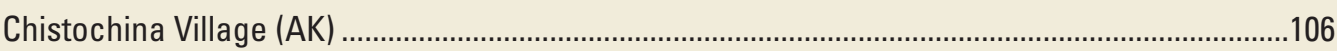

Chippewa Cree Tribes of the Rocky Boy's Reservation (MT) ……...........................................108

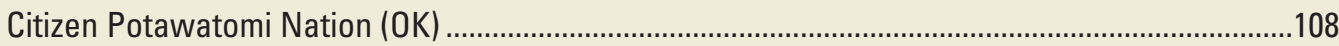

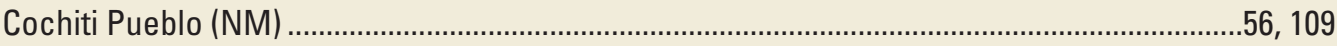

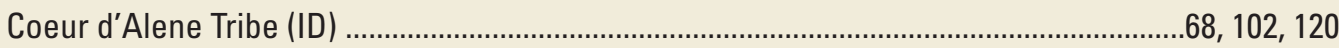

Confederated Salish and Kootenai Tribes (MT) ......................................................50, 52, 108, 116

Confederated Tribes of the Colville Reservation (WA) ........................................................71, 72

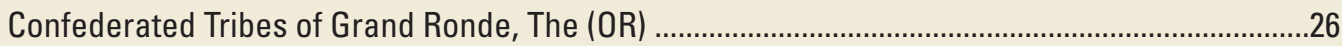

Confederated Tribes of the Umatilla Indian Reservation (OR)..............................79, 80, 81, 110, 111

Confederated Tribes of the Warm Springs Reservation (OR) ..............................79, 81, 110, 120, 124

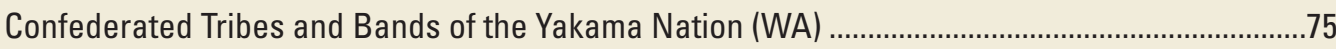

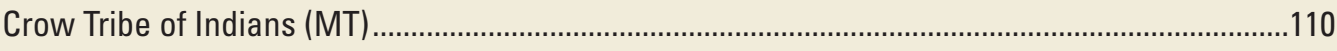

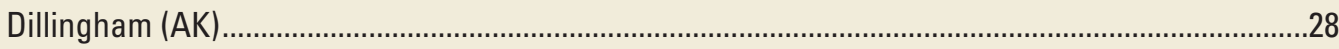

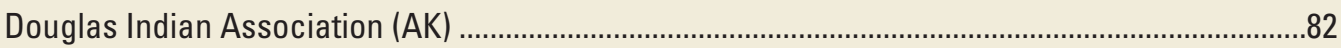

Eastern Shoshone Tribe (Wind River Reservation) (WY) .....................................................100, 109

Eklutna Native Village (AK) .............................................................................................106, 110

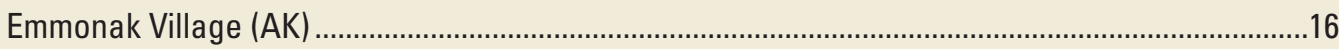

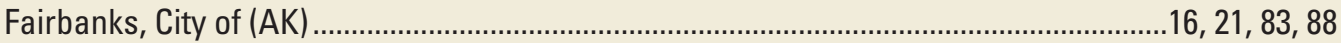

Fallon Paiute Shoshone Tribe (Fallon Colony) (NV) ...................................................................

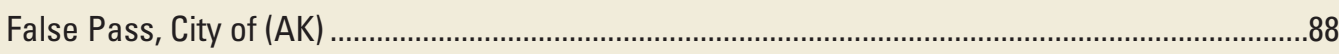

Flathead Reservation (see Confederated Salish and Kootenai Tribes) (MT).............................50, 52

Fond du Lac Band of Lake Superior Chippewa (MN) ........................................................42, 43

Fort Apache (see White Mountain Apache Tribe) (AZ) ..........................................26, 104, 109, 111

Fort Berthold Reservation (see Three Affiliated Tribes) (ND) _..............................................97, 108

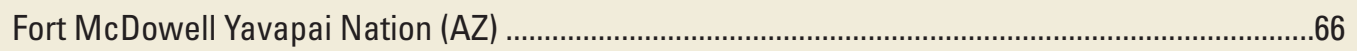

Fort Peck Assiniboine and Sioux Tribes (MT) .......................................................50, 108, 110 
Fort Totten (see Spirit Lake Nation/Tribe) (ND) ………........................................................96, 97

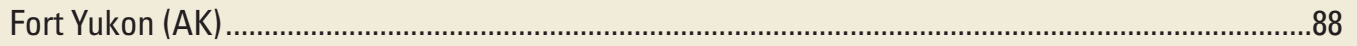

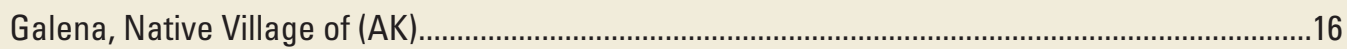

Gila River Indian Community (AZ) ....................................................................................62, 67

Grand Portage Band of Lake Superior Chippewa (MN) ..............................................42, 43, 108

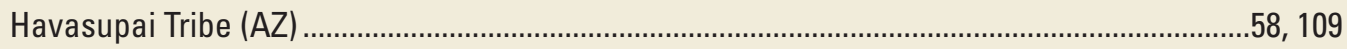

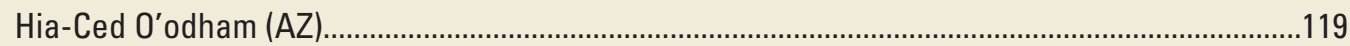

Hidatsa Tribe (see Three Affiliated Tribes) (ND) ....................................................................108

Ho-Chunk Nation (WI) ...................................................................................22, 23, 32, 41, 95

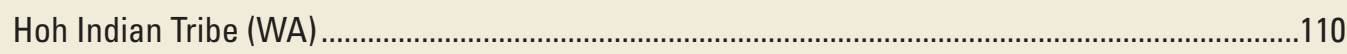

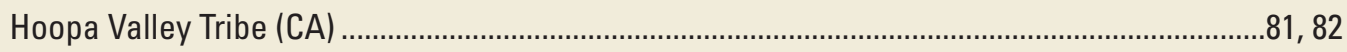

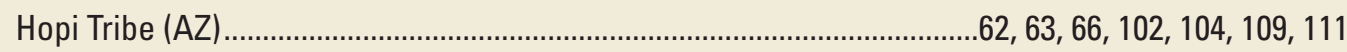

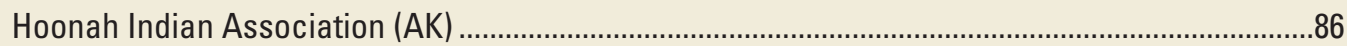

Houlton Band of the Maliseet Indians (ME) ….................................................. 34, 108, 112

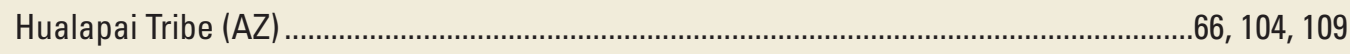

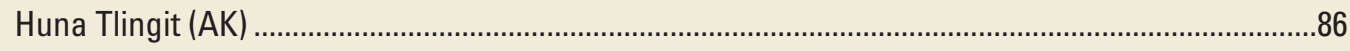

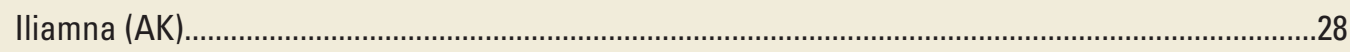

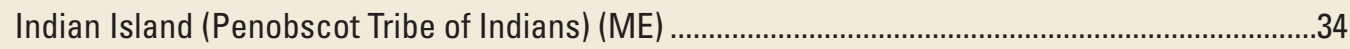

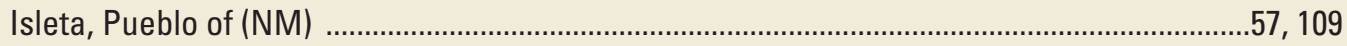

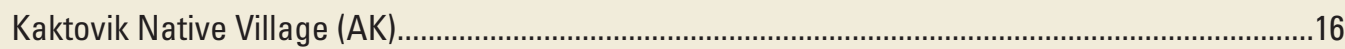

Kaibab Band of Paiute Indians (AZ) ..................................................................60, 66, 67, 111

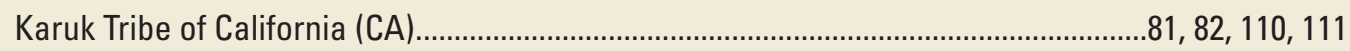

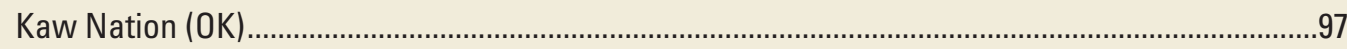

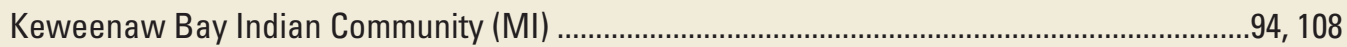

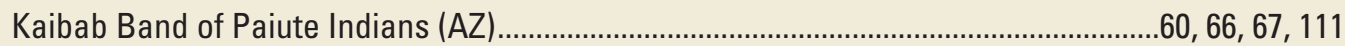

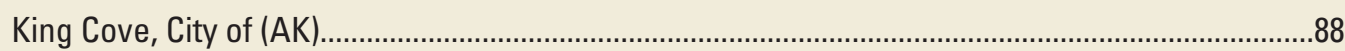

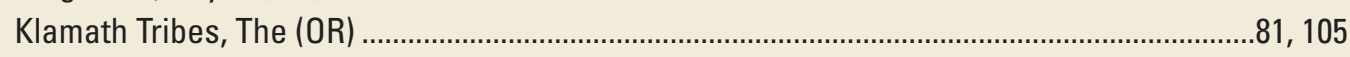

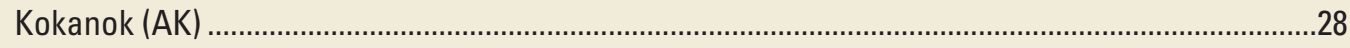

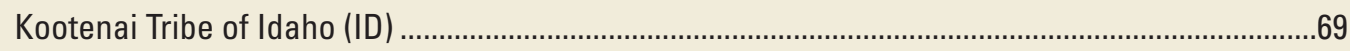

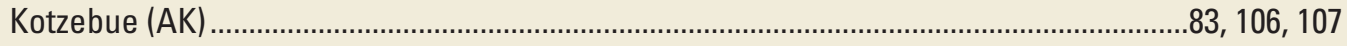

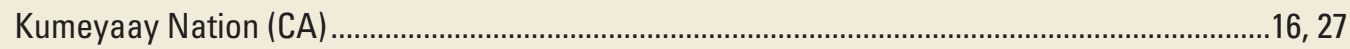

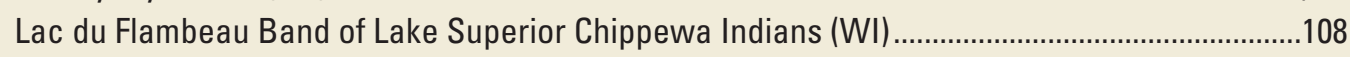

Lac Vieux Desert Band of Lake Superior Chippewa (MI) ..........................................................95

Lower Brule Sioux Tribe (SD) ................................................................................... 110

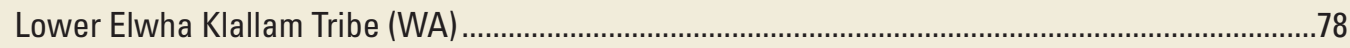

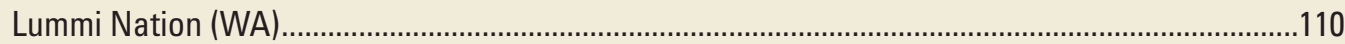

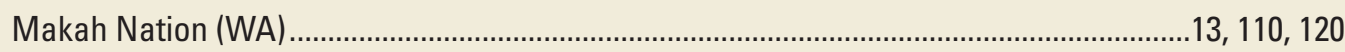

Maliseet Tribes (see Houlton Band of Maliseet Indians (ME) ...................................33, 34, 108, 112

Mandan Tribe (see Three Affiliated Tribes) (ND) .....................................................................

Menominee Indian Tribe of Wisconsin (WI)..........................................................38, 40, 108

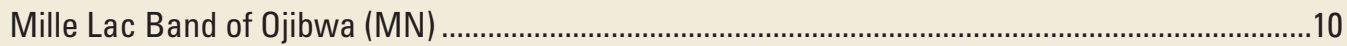

Mole Lake Reservation (see Sokaogon Chippewa Community) (WI) .........................................108

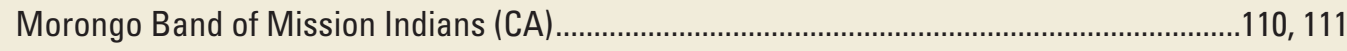

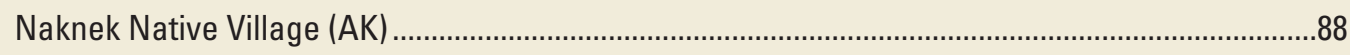

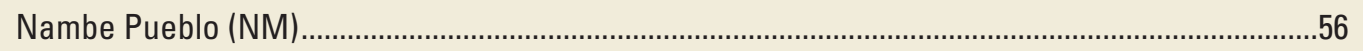


Nanwalek, Native Village of (AK) 107

Navajo Nation (AZ, NM, UT) $12,13,25,26,57,58,59,60,61,62,63,66,102,103,109,111,124$

Nelson Lagoon (AK) .. .88

Nenana Native Village (AK).

16

Nez Perce (Ni Mii Pu) Tribe (ID)

$93,109,110$

Nisqually Indian Tribe (WA)

77,110

Nondalton Village (AK). .28

Nooksack Indian Tribe (WA)

71,110

Northern Arapaho Tribe (Wind River Reservation) (WY)

100,109

Northern Cheyenne Tribe (MT)

$53,108,110$

Nottawaseppi Huron Band of Potawatomi (MI)

46,108

Oglala Sioux Tribe (Pine Ridge Reservation) (SD)

13,56

Ohkay Owingeh (NM) .108

Omaha Tribe of Nebraska and lowa (NE) .116

Oneida Nation (NY)

95,108

Oneida Tribe of Wisconsin (WI) 116

Onondaga Nation (NY)

$48,98,99$

Osage Nation (OK)

$64,65,66$

Paiute Indian Tribe of Utah (UT)

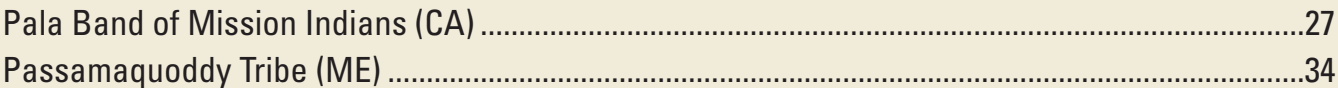

Pauma Band of Luiseno Indians.................................................................................................

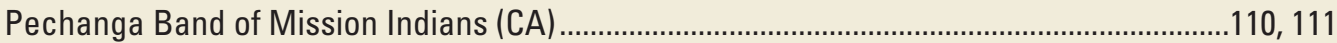

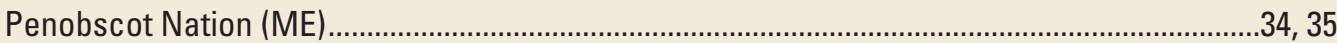

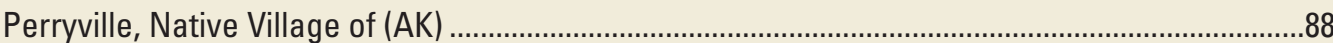

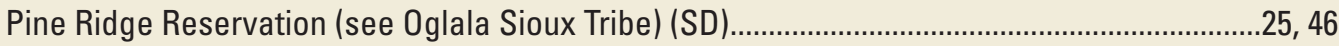

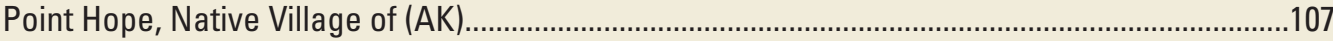

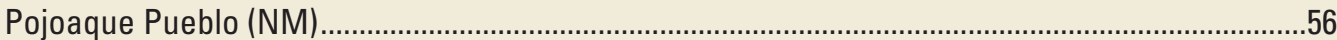

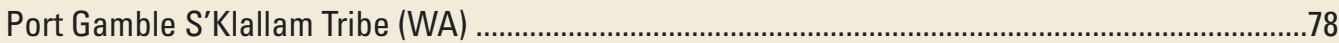

Port Madison Indian Reservation (see Suquamish Tribe) (WA) ..................................................120

Prairie Band of Potawatomi Nation (KS) ...................................................................................

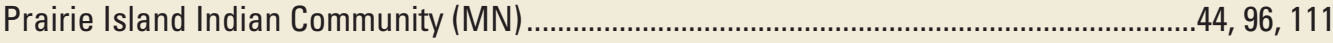

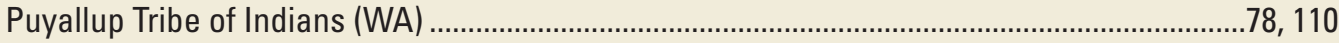

Pyramid Lake Paiute Tribe (NV) ................................................................... 108, 110, 111

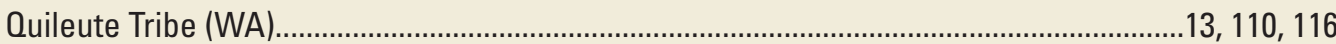

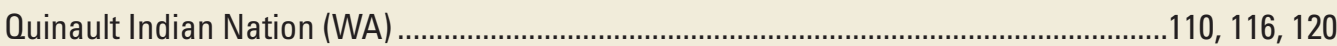

Rainy River First Nations (Canada) .........................................................................................42

Red Lake of Chippewa Indians (MN) .................................................................................10

Rosebud Sioux Tribe (SD) ............................................................................11, 46, 108, 118

Rocky Boy's Reservation (see Chippewa Cree Tribes of the Rocky Boy's Reservation) (MT)......108

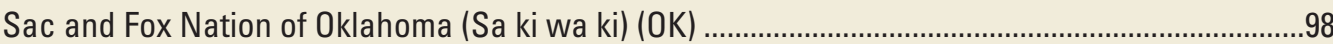

Saginaw Chippewa Indian Tribe of Michigan (MI) ....................................................................

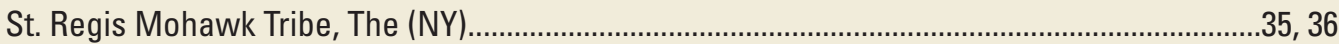

Salish and Kootenai Tribes (see Confederated Salish and Kootenai Tribes) (ID) ......50, 52, 108, 116

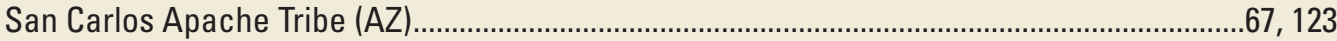

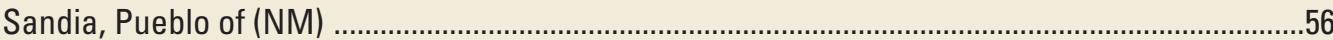

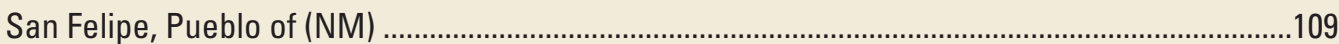

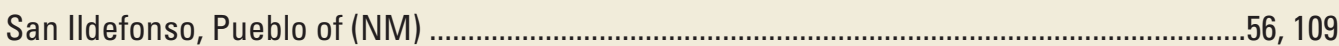

San Juan Pueblo (see Ohkay Owingeh) (NM) ................................................................. 35,5

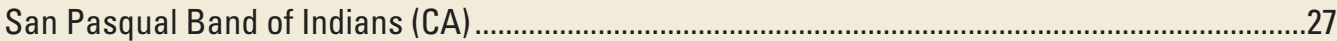




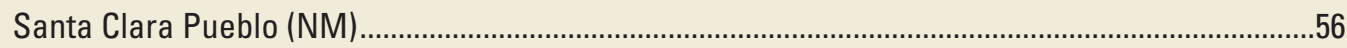

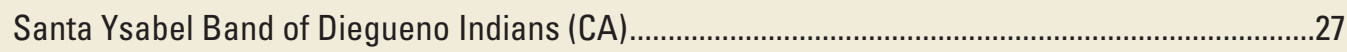

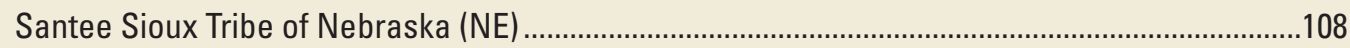

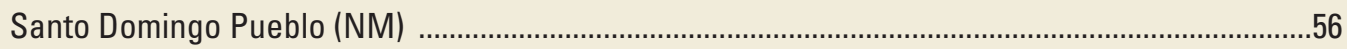

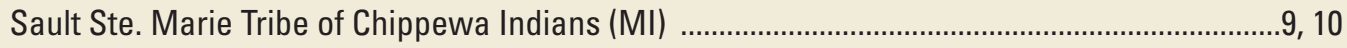

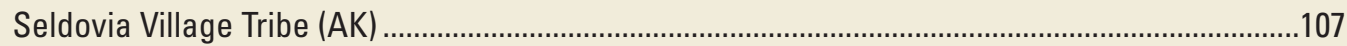

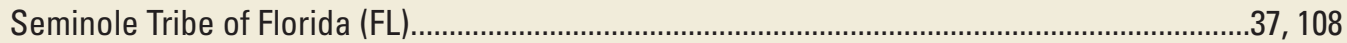

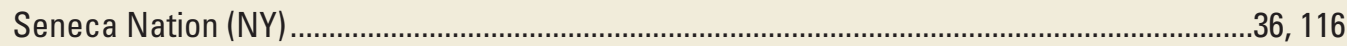

Shakopee Mdewakanton (Dakota) Sioux Community (MN) ...........................................................4

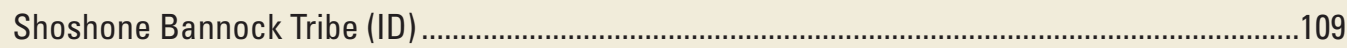

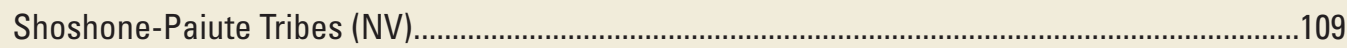

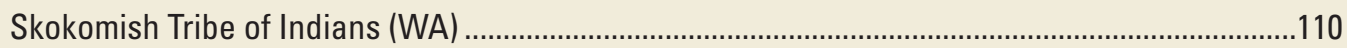

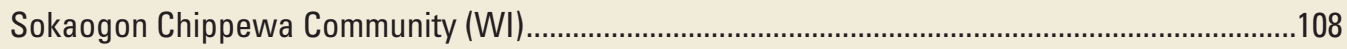

Southern Ute Indian Tribe (CO) ..................................................................................100, 109

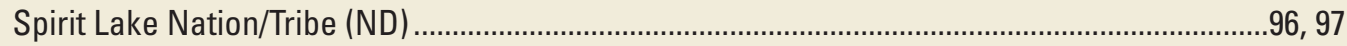

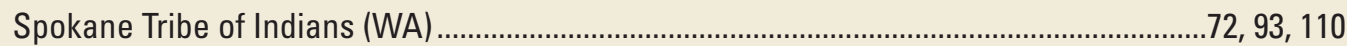

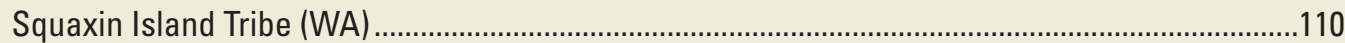

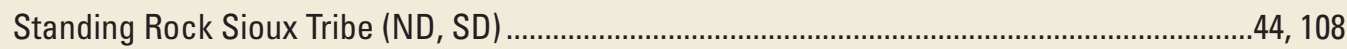

Stockbridge-Munsee Band of Mohican Indians (WI) ………............................................41, 108

Summit Lake Paiute Tribe (NV) ...........................................................................................

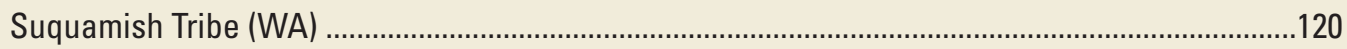

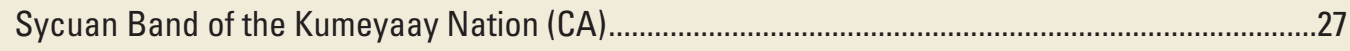

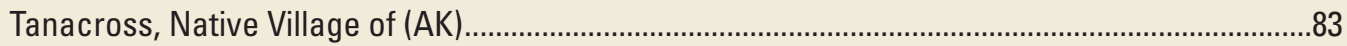

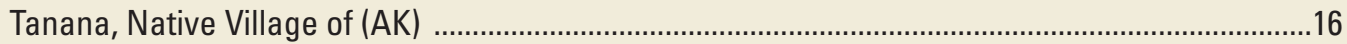

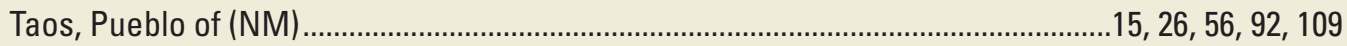

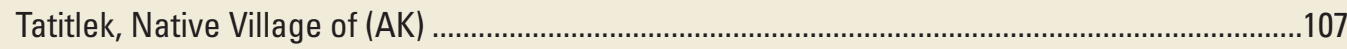

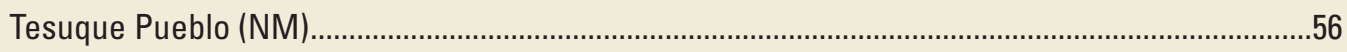

Three Affiliated Tribes of the Fort Berthold Reservation (ND) ...................................................108

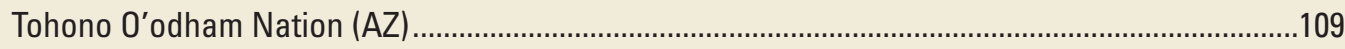

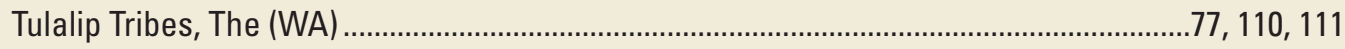

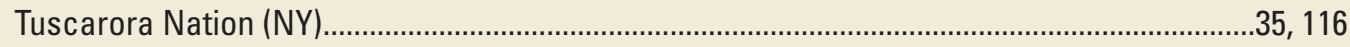

Umatilla Tribes (see Confederated Tribes and Bands of the Umatilla Reservation) (OR) .....................................................................79, 80, 81, 110, 111

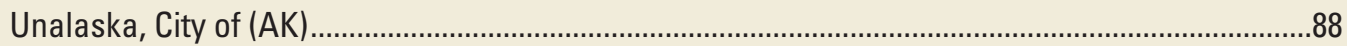

Upper Sioux Community (MN) ..................................................................................................

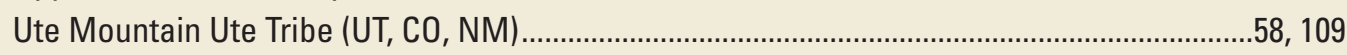

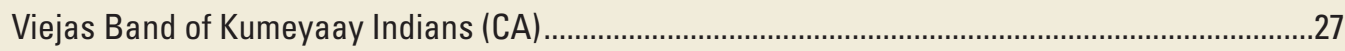

Walker River Paiute Tribe (NV) .............................................................70, 100, 105, 109, 110, 111

Warm Springs Tribes (see Confederated Tribes and

Bands of the Warm Springs Reservation) (OR) ................................79, 81, 110, 116, 120, 124

White Earth Band of the Minnesota Chippewa Tribe (MN) ..........................................................4

White Mountain Apache Tribe (AZ) ................................................................ 104, 109, 111

Wind River Reservation (Northern Arapaho Tribe or Eastern Shoshone Tribe) (WY)............100, 109



Yakama Nation (see Confederated Tribes and Bands of the Yakama Nation) (WA).

$.74,75,77,79,110,120$

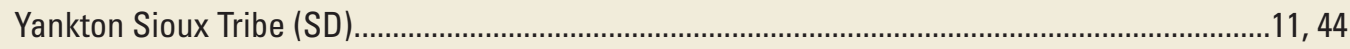

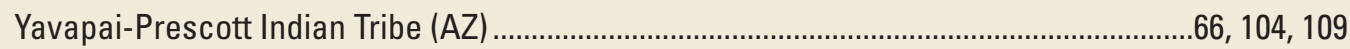

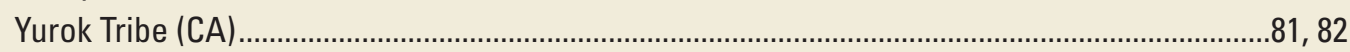

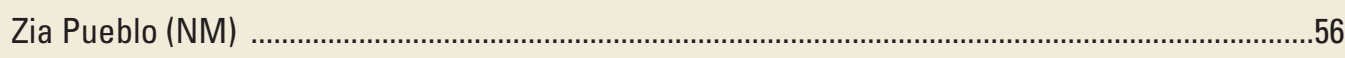

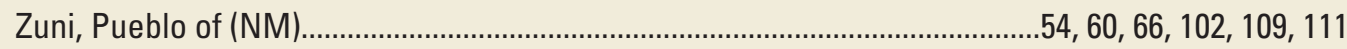




\section{Organizations or Events Related to American Indians or Alaska Natives Mentioned in the Report}

Names in this report are the most accurate that could be readily determined from several sources. Any inaccuracies are unintentional. Corrections are welcome and may be submitted to Susan Marcus (U.S. Geological Survey National Center, MS 104, 12201 Sunrise Valley Dr., Reston, Virginia 20192; 703-648-4437; fax 703-648-5470; smarcus@usgs.gov)

\section{Organization/Event}

1854 Authority 42,43

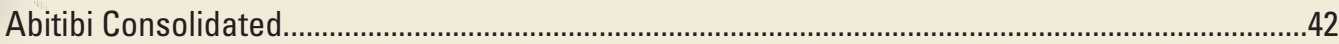

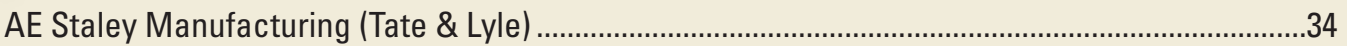

Agency for Toxic Substances and Disease Registry

(U.S. Department of Health and Human Services) ....................................................12, 34

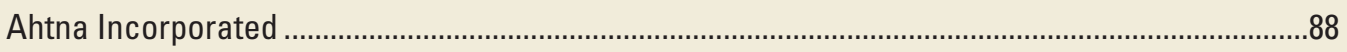

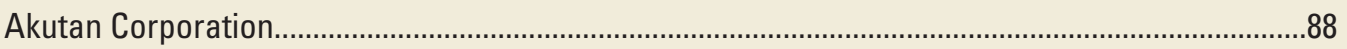

Alaska Department of Environmental Conservation ...........................................................................82

Alaska Division of Geological \& Geophysical Surveys ......................................................................88

Alaska Maritime National Wildlife Refuge .........................................................................................107

American Indian Science and Engineering Society (AISES) ........................................................2

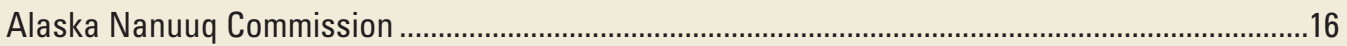

Alaska Sea Otter and Steller Sea Lion Commission, The .............................................................107

Albuquerque, City of .............................................................................................13, 56, 57, 102, 109

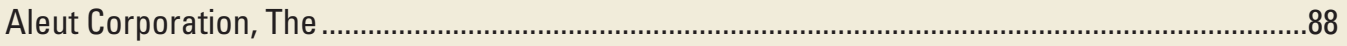

Alliance of Tribal Tourism Advocates .................................................................................10, 11, 118

American Fisheries Society ................................................................................................................79

American Indian Science and Engineering Society (AISES) ............................................................

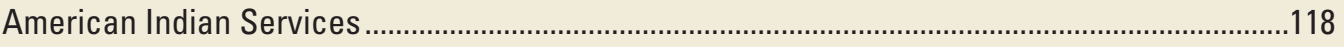

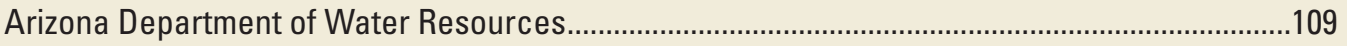

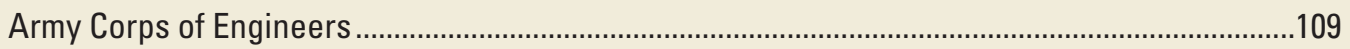

Bacterial Cold Water Disease Research Group ..............................................................................70

Big Cypress National Preserve...........................................................................................................37

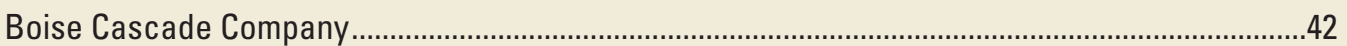

Blue Cloud Abbey......................................................................................................8, 38, 45, 77, 118

Bonneville Power Administration ...................................................................................................72

Bristol Bay Native Corporation (AK) ...................................................................................84, 120

British Broadcasting Corporation .................................................................................................13

Bureau of Indian Affairs (BIA) .....1, 7, 21, 34, 48, 53, 59, 67, 105, 108, 109, 110, 111, 118, 119, 120, 123

Bureau of Indian Affairs Annual Pacific Northwest GIS Conference...........................................120

Bureau of Land Management (BLM) ................................................................67, 83, 88, 124

Bureau of Reclamation ..........................................................62, 66, 70, 74, 81, 100, 103, 105, 109

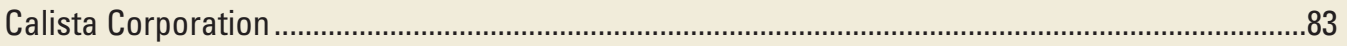

Canyon De Chelly National Monument .............................................................................26, 58, 62

Chippewa Ottawa Resource Authority.............................................................................8, 9, 116

Chippewa Township (MI) ......................................................................................................... 10

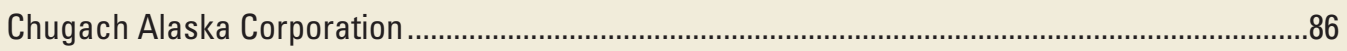

Chugach Regional Resources Commission.................................................................................107 
Columbia River Inter-Tribal Fish Commission......................................................................

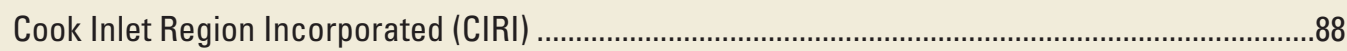

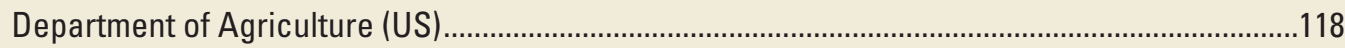

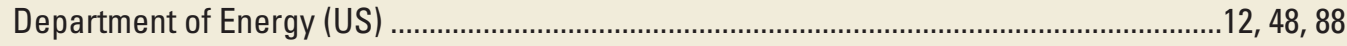

Department of Health and Human Services (US) _..................................................................12

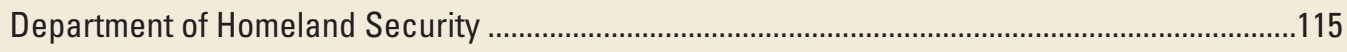

Deschutes River Basin Conservation Planning ......................................................................124

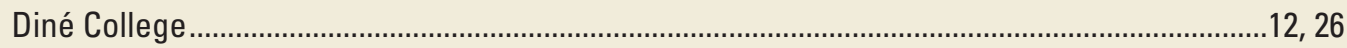

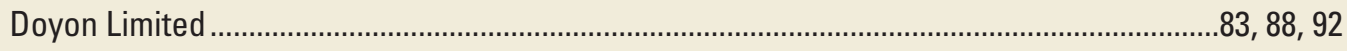

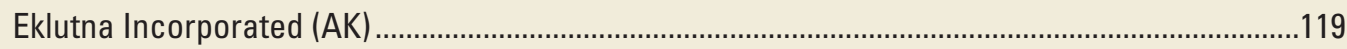

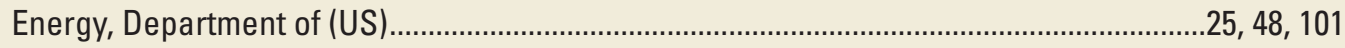

Environmental Protection Agency (US) ............................ 10, 11, 25, 34, 44, 48, 82, 98, 104, 116, 118

Environmental Systems Research Institute, Inc. (ESRI) .........................................................16

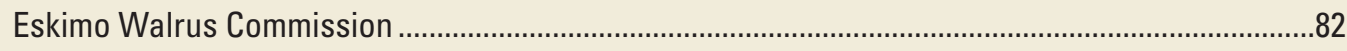

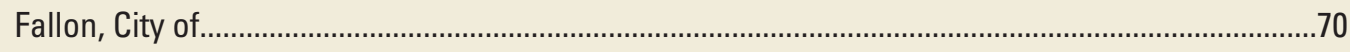

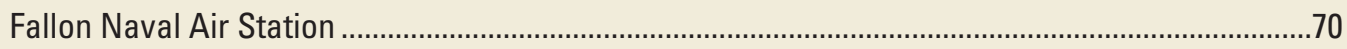

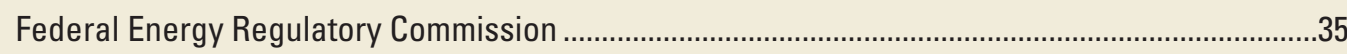

Federal Geographic Data Committee ..................................................................21, 22, 115, 120

Federal Subsistence Management Program (joint DOI and USDA)............................................16

Fish and Wildlife Service (US) ..................................22, 37, 38, 42, 56, 77, 79, 81, 82, 86, 93, 102, 105

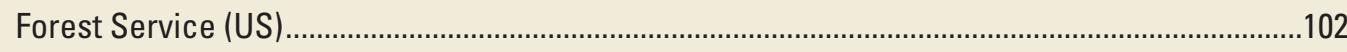

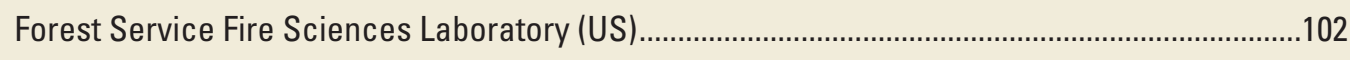

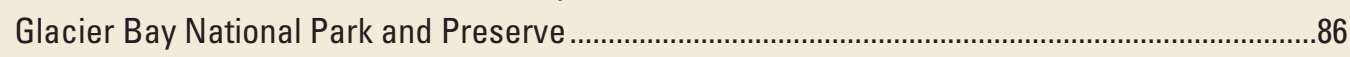

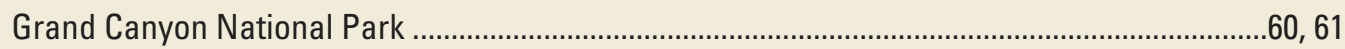

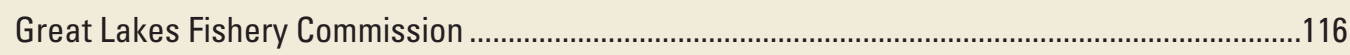

Great Lakes Indian Fish \& Wildlife Commission ....................................................................116

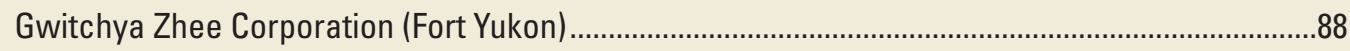

Haskell Indian Nations University ..................................................................................25, 47

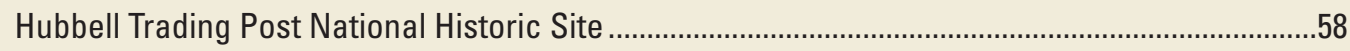

Haudenosaunee Environmental Task Force ............................................................................116

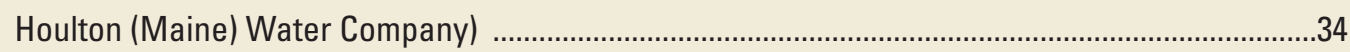

Incorporated Research Institutions for Seismology ...............................................................57

Indian Health Service ................................................................................ 10, 12, 103, 118

Indigenous Knowledge Center for Education and Science Impacts, Sinte Gleska University.......24

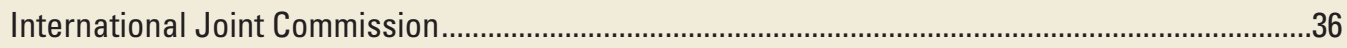

Inter-Tribal Council of Michigan..........................................................................................

Kawerak, Inc. Natural Resources Department............................................................................106

Keweenaw Bay Indian Community Environmental Department......................................................94

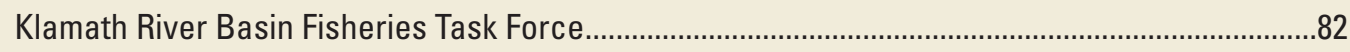

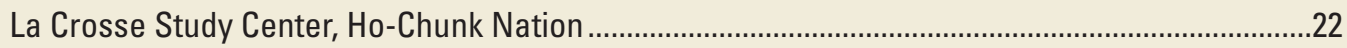

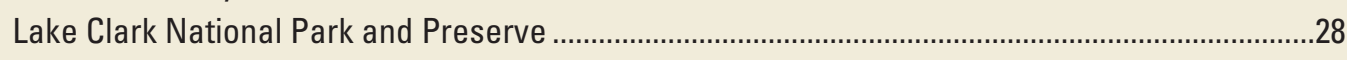

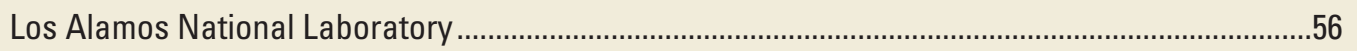




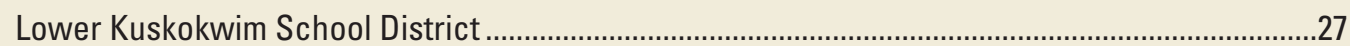

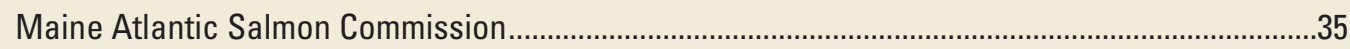

Maine Department of Environmental Protection.............................................................................33

Maniilaq Association Subsistence Program..........................................................................107

Menominee Reservation Lake Sturgeon Enhancement Committee ………….................................38

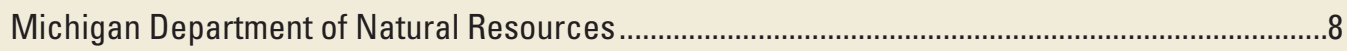

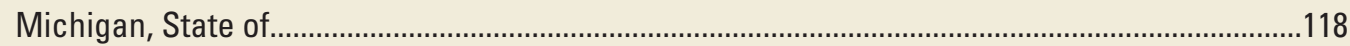

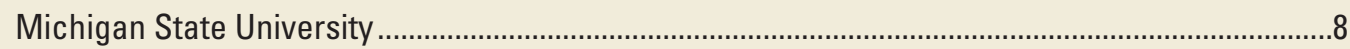

Michigan Tribal Environmental Group .................................................................................18

Minnesota Department of Natural Resources................................................................... 42, 43

Mohawk Council of Akwesasne.................................................................................................

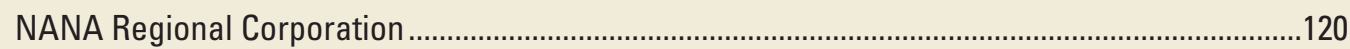

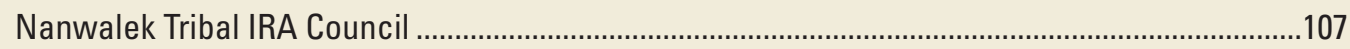

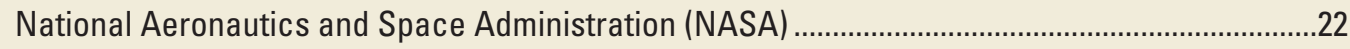

National Conservation Training Center, U.S. Fish and Wildlife Service............................................22

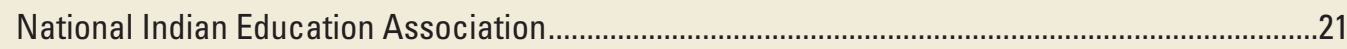

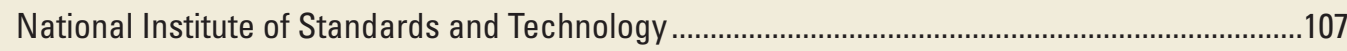

National Oceanic and Atmospheric Administration (NOAA) …........................................21, 57, 59

National Park Service ........................................................ 13, 28, 42, 58, 60, 61, 62, 72, 86, 119

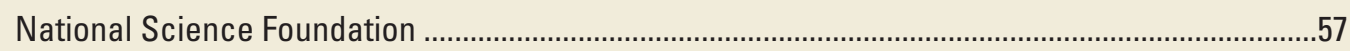

Native American Fish and Wildlife Society ..................................................................... 116

Natural Resources Conservation Service (USDA) ....................................................................124

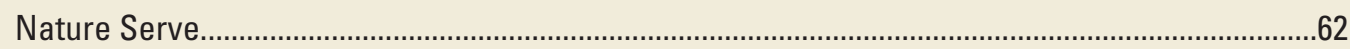

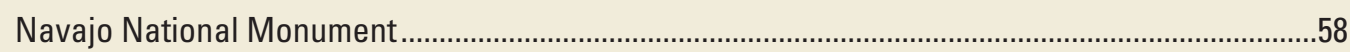

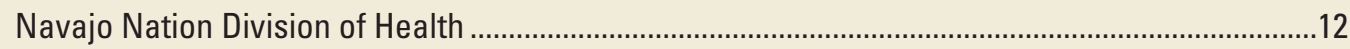

Navajo Nation Environmental Protection Agency ……………...................................................

Navajo Nation Historic Preservation Department …….............................................................12

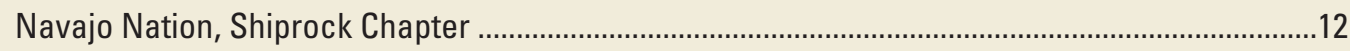

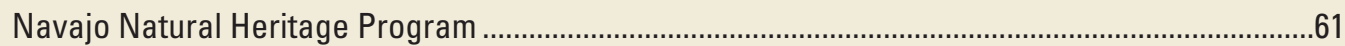

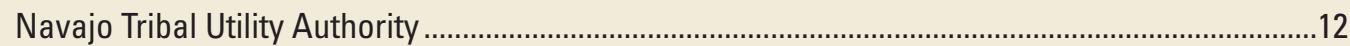

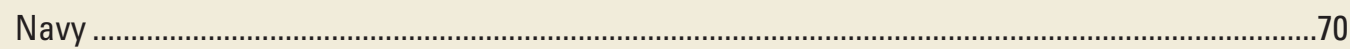

New Mexico Bureau of Geology and Mineral Resources ..........................................................56

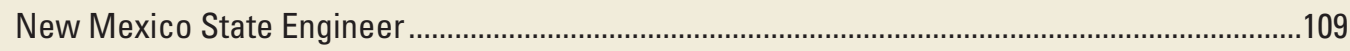

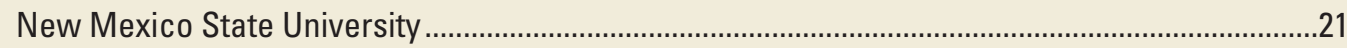

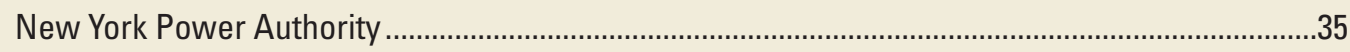

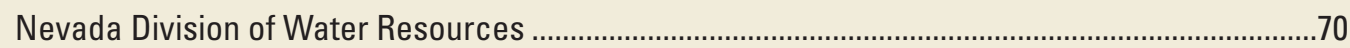

Northern Arizona University......................................................................................25, 26, 66

North Slope Borough Department of Wildlife Management............................................16, 17, 106

Northwest Indian Fisheries Commission ................................................................13, 70, 93

Oceti Sakowin Experience ..................................................................................................118

Oklahoma Department of Agriculture, Food, and Forestry (ODAFF) ............................................98

Oklahoma Department of Wildlife Conservation ............................................................................49

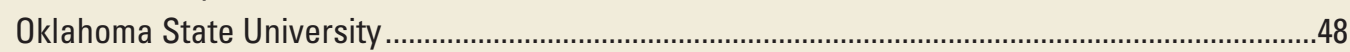

Onondaga County (New York) Soil and Water Conservation District .............................................116

Ontario (Canada) Ministry of Natural Resources ..........................................................................42

Oregon Department of Fish and Wildlife...............................................................................

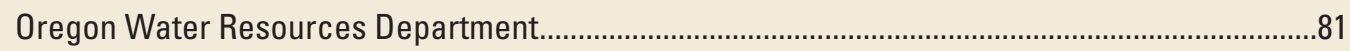

Osage Nation Environmental and Natural Resource Department .....................................................48 


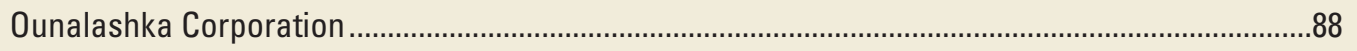

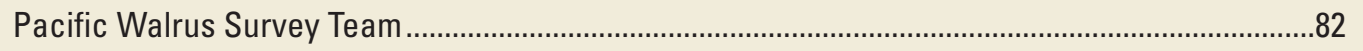

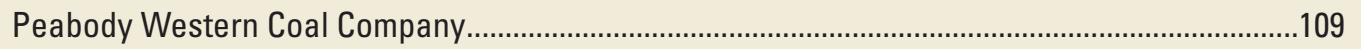

Petrified Forest National Monument ..........................................................................................62

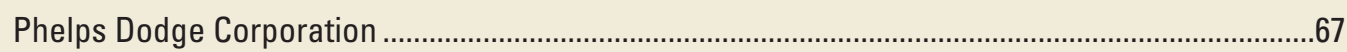

Pipe Spring National Monument...............................................................................................60

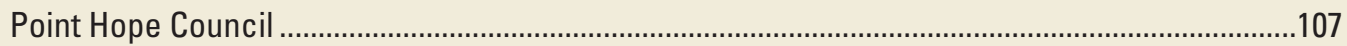

Pueblo of Zuni Fish and Wildlife Department................................................................................60

Rainy Lake and Namakan Reservoir Water Level Monitoring Committee ......................................42

Rainy River First Nations (Anishinaabe and Ojibwa peoples) ........................................................42

Rosebud Sioux Water Resources Department ...............................................................................

Rural Geospatial Innovations in America (RGIS) .....................................................................115

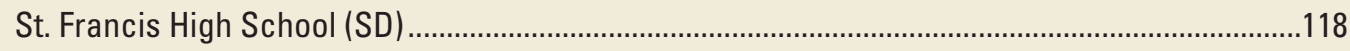

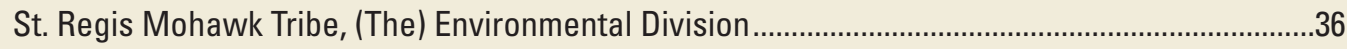

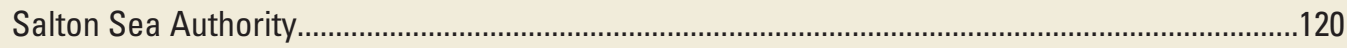

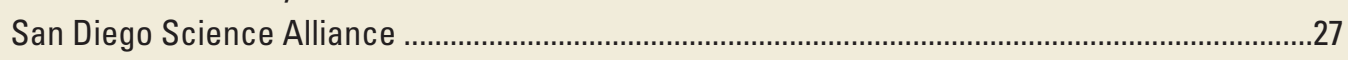

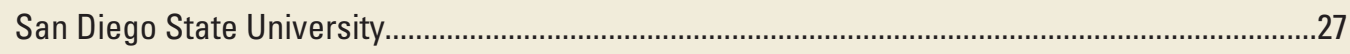

Satus Wildlife Area

Science Application International Corporation (SAIC) .................................................................11

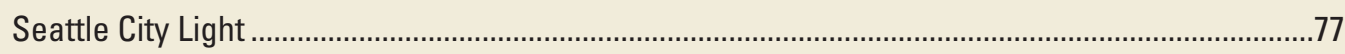

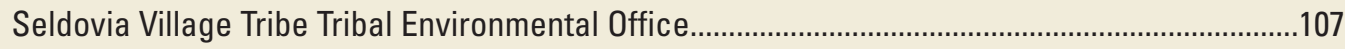

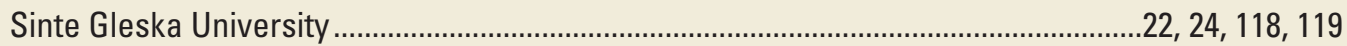

Skagit System Tribal Cooperative (composed of the Sauk-Suiattle, Swinomish, and Upper Skagit Tribes) (WA) .......................................................................................

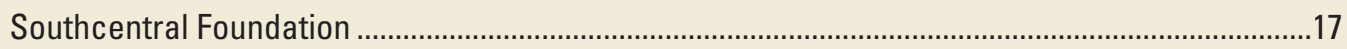

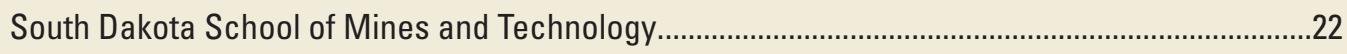

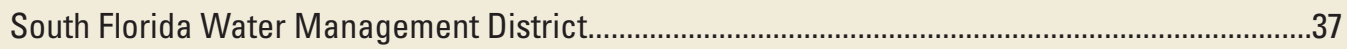

Southern Paiute Consortium (see Kaibab Paiute Tribe and the Paiute Indian Tribe of Utah)...60, 66

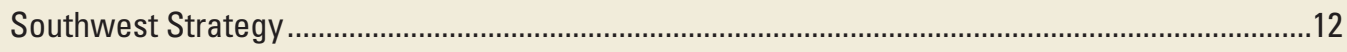

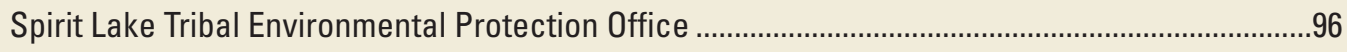

Summer of Applied Geophysics Experience .............................................................................

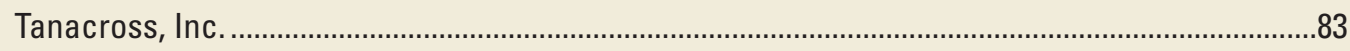

Tate \& Lyle

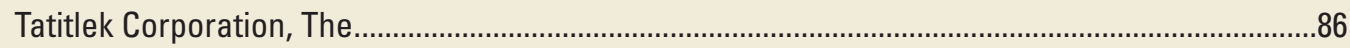

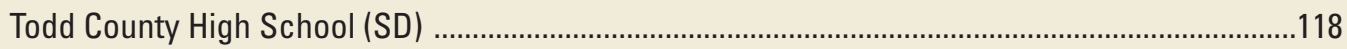

Toppenish National Wildlife Refuge ......................................................................................

United Sioux Tribes Development Corporation............................................................................123

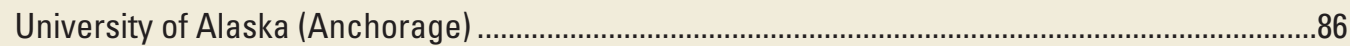

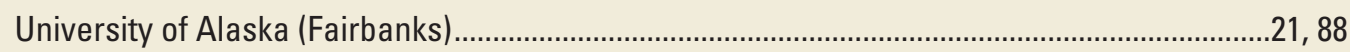

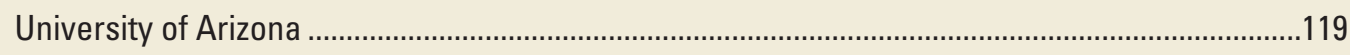

University of Maine Analytical Environmental Chemistry Laboratory .............................................34

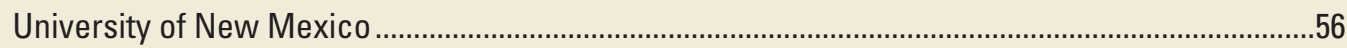

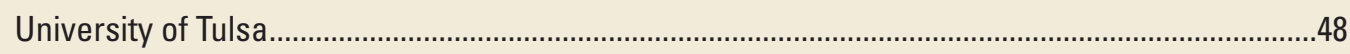

Upper Columbia River White Sturgeon Recovery Team...................................................................72

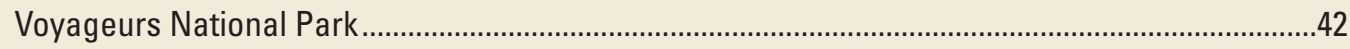

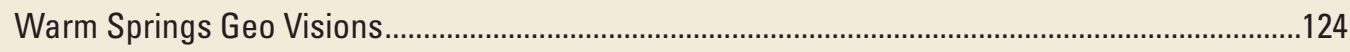

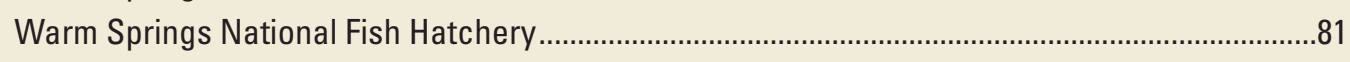

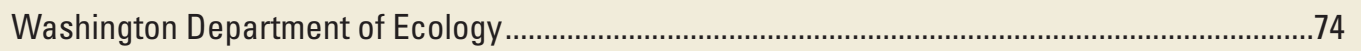


Washington Department of Fish and Wildlife .79

White House Initiative on Tribal Colleges and Universities...........................................................16

White Salmon Watershed Management Council..............................................................................75

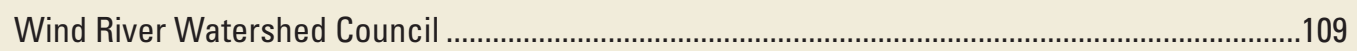

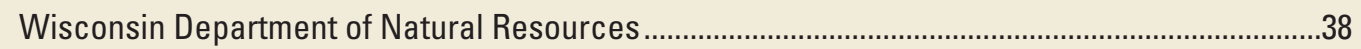

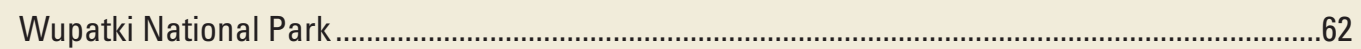

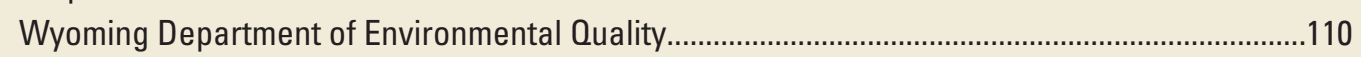

Yakama Nation Department of Natural Resources .....................................................................

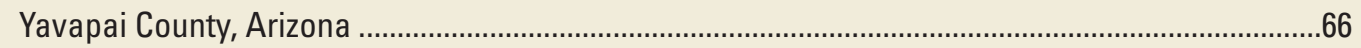

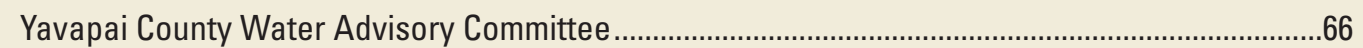

\section{States Mentioned in the Report}

\section{State}

Alaska ... 1, 2, 4, 16, 17, 21, 26, 27, 28, 29, 82, 83, 84, 85, 86, 87, 88, 92, 93, 105, 106, 107, 110, 118, 120, 125 Arizona......................12, 13, 25, 26, 58, 59, 60, 61, 62, 63, $66,67,102,103,104,109,111,119,123,124$ California ....................................................................................... $27,81,82,110,111,133$ Colorado ................................. 12, 13, 25, 26, 48, 56, 58, 59, 62, 63, 66, 69, 100, 102, 103, 114, 123

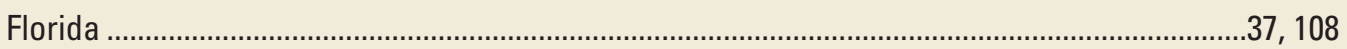

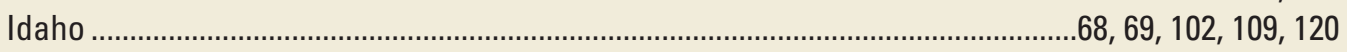

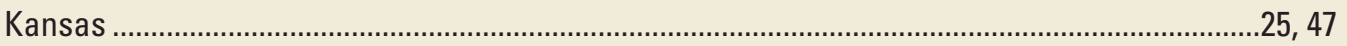

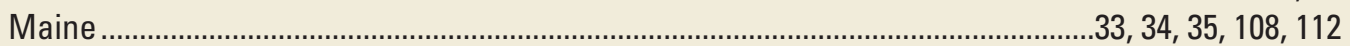

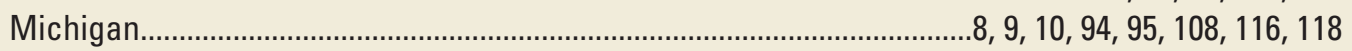

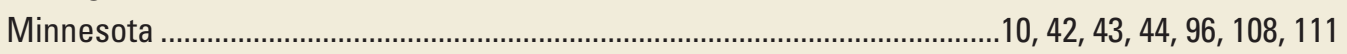
Montana ….............................................................................. $50,51,52,53,69,102,108,110,116$

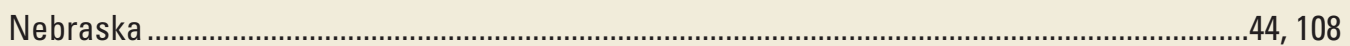

Nevada $69,70,100,105,109,110,111$ New Mexico.............................. 12, 13, 21, 25, 26, 54, 56, 57, 58, 59, 62m, 63, 102, 103, 109, 119, 123

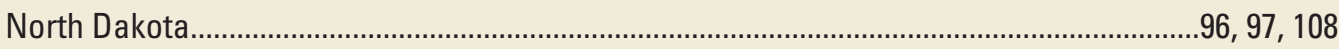

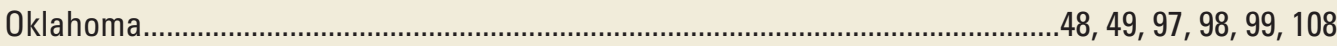
Oregon .............................................. 26, 70, 75, 79, 80, 81, 82, 105, 110, 111, 118, 119, 120, 124

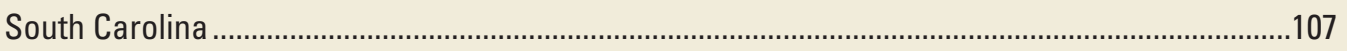

South Dakota ….................................... $10,10,11,22,24,25,38,44,45,46,56,77,108,118,119,125$

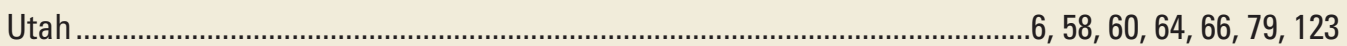

Washington ......................................13, 70, 71, 72, 74, 75, 77, 78, 79, 93, 110, 111, 116, 119, 120, 125

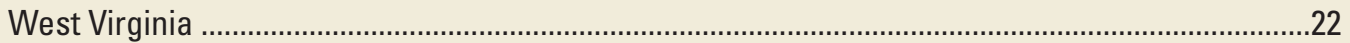

Wisconsin................................................................................... $7,22,37,38,40,41,95,108$

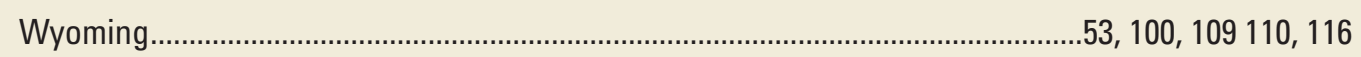




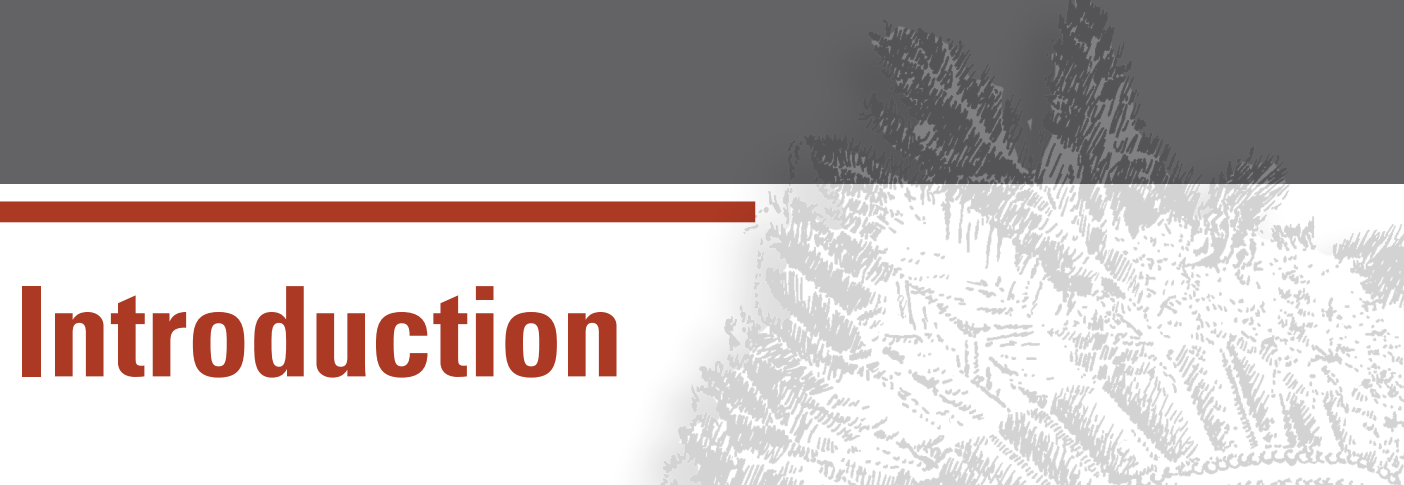


ars

is

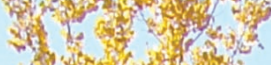

Non,

in. $3,5 \%$

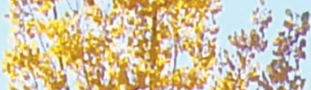

and

and

a

2.

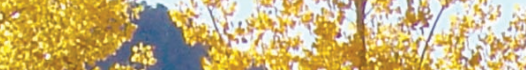

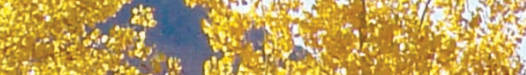

17.

(1)

6.

3. 17.

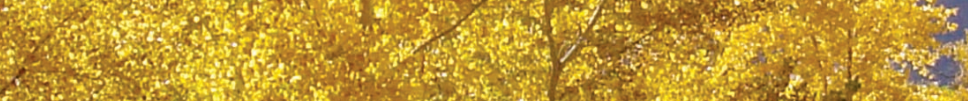
670

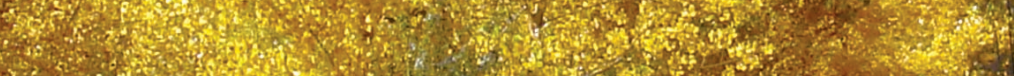

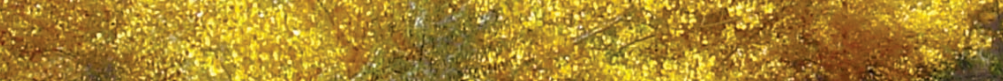
7.

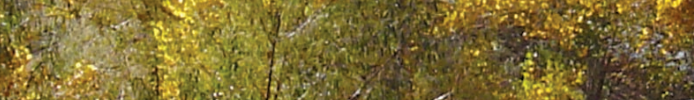

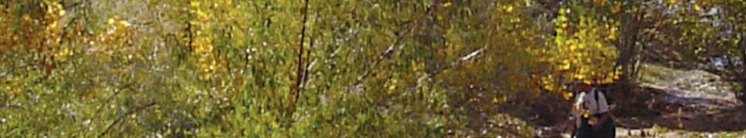

(10.6.

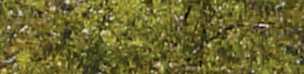

(5)

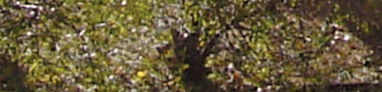

$\rightarrow$ H $n$
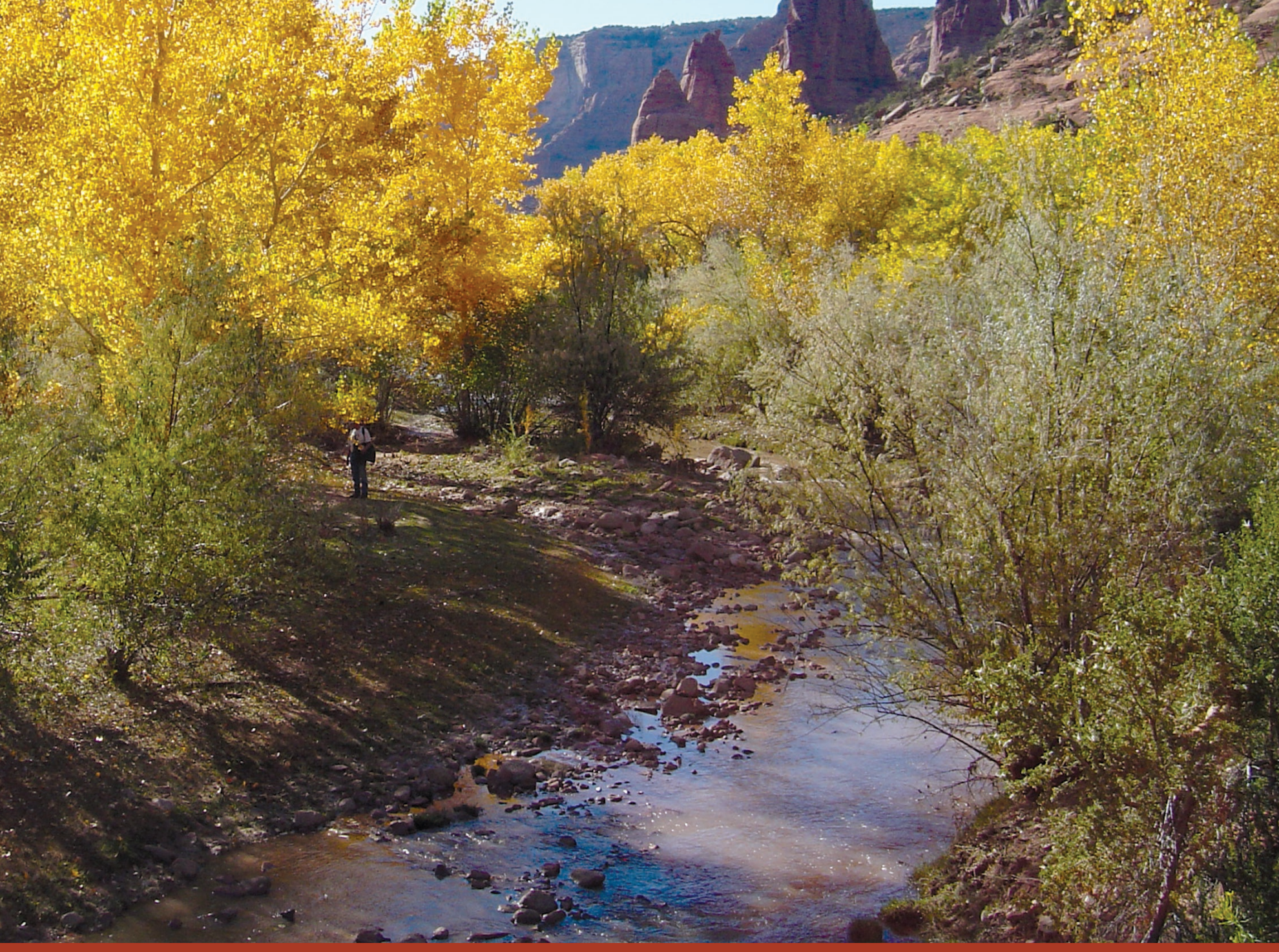
$\frac{1}{20}+2$

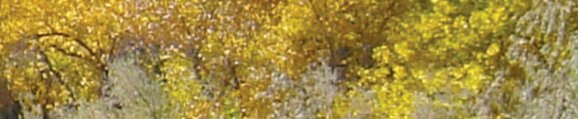

10

36

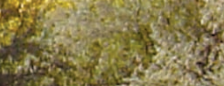

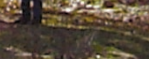

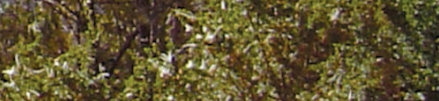

Fall in Canyon de Chelly, Arizona. Photograph by Rob Klotz, USGS. 


\title{
U.S. Geological Survey Activities Related to American Indians and Alaska Natives Fiscal Year 2004
}

\author{
By U.S. Geological Survey
}

\section{Introduction}

Information is a resource for Native American governments, communities, organizations, and people. The U.S. Geological Survey (USGS) provides technical expertise, reports, and other impartial information that Native Americans can use for making decisions about issues such as traditional and other resources, water, land use, and the health of the environment. Native American decisions based on USGS data and analyses support the goals of Native American self-sufficiency, economic development, and conservation.

The USGS works in cooperation with American Indian and Alaska Native governments, conducting research on (1) water, energy, and mineral resources, (2) animals and plants that are important for traditional lifeways, or have environmental or economic significance, and (3) natural hazards. Digital data about cartography, energy and mineral resources, streamflow, biota, and other topics are available to American Indian and Alaska Native individuals and institutions. The USGS also recognizes the need to learn from and share knowledge with Native peoples. This report describes most of the activities that the USGS conducted with American Indian and Alaska Native governments, educational institutions, and individuals during Federal fiscal year (FY) 2004. Most of these USGS activities were collaborations with Tribes, Tribal organizations, or professional societies. Other activities were conducted cooperatively with the Bureau of Indian Affairs (BIA) or other Federal entities.

Tribal governments, educational institutions, and other Tribal organizations that use Geographic Information Systems (GIS) and other digital technologies can rely on USGS data for specific purposes. Using these technologies provides Tribal governments with additional means of managing lands and resources for the benefit of current and future generations. The USGS recognizes the need to make its information available to Tribal governments and to work with those governments and other institutions to improve data management capabilities.

Tribal institutions have varying needs, interests, and capacities. The USGS is responding to those needs by transferring scientific information to American Indian and Alaska Native governments and by training employees of those governments to conduct scientific studies and to improve scientific data management. Other USGS goals are (1) to encourage American Indians and Alaska Natives to pursue careers in the natural sciences and information technology, (2) to create internships, and (3) to develop other means of providing jobs for these students. The USGS is striving to increase the job opportunities for Native American students by identifying, improving, and disseminating information about available hiring mechanisms and by alerting USGS managers to the pool of qualified Native American students. USGS works with Tribal colleges and universities to fulfill these goals.

The USGS is the Federal science bureau within the Department of the Interior (DOI). The USGS does not have regulatory or land management responsibilities. As described in this report, there are many USGS activities that are directly relevant to American Indians, Alaska Natives, and to Native lands. A USGS Web site, dedicated to making the USGS more accessible to American Indians, Alaska Natives, their governments, and institutions, is available at www.usgs.gov/indian. This Web site includes information on how to contact USGS American Indian/Alaska Native Liaisons, training opportunities, and links to other information resources. This report and previous editions are also available through the Web site. 


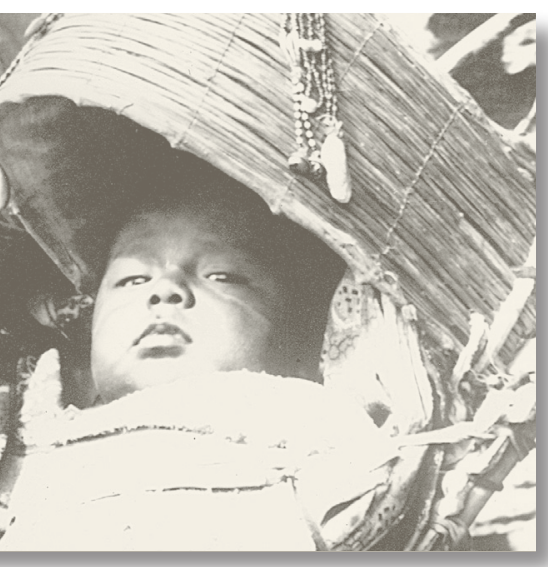

The USGS realizes that Native American knowledge and cultural traditions of living in harmony with nature result in unique Native American perspectives that enrich USGS studies. The USGS seeks to increase the sensitivity and openness of our scientists to the breadth of Native American knowledge, expanding the information on which our research is based.

One type of USGS activity described in this report occurs in the course of formal studies, conducted through existing USGS programs, that involves collection of specific types of data as well as investigative and research projects. These projects typically last 2 or 3 years, although a few are parts of longer-term activities. Some projects are funded through cooperative agreements between the USGS and individual Tribal governments, or are funded by the BIA. The USGS provides matching funds for some cooperative projects. These projects may also receive funding from the U.S. Environmental Protection Agency (EPA), the Indian Health Service (part of the Department of Health and Human Services), or other Federal agencies. The USGS routinely works with its sister bureaus in the Department of the Interior to provide the scientific information and expertise needed to meet the Department's science priorities.

Another type of USGS activity is less formal. These activities are designed by USGS employees and are usually conducted as collateral tasks that result from one or more USGS employees identifying and responding to an observed need. These endeavors are prompted by employee interests and frequently involve educational projects. Such projects are often reciprocal learning and teaching experiences for both USGS employees and Native participants. Through these activities, USGS employees expand their approaches to observations and interpretations of natural science. Increasingly, some of the educational activities are becoming parts of formal USGS projects.

USGS employees have also taken the initiative to assist American Indians and Alaska Natives through participation in several organizations that were created to promote awareness of science career opportunities among Native peoples and to help build support and communication networks. One such group is the American Indian Science and Engineering Society (AISES). USGS employees can join this organization on a voluntary basis, bringing the benefits of this expanded network to the USGS.

Each major organizational unit of the USGS has identified an American Indian/Alaska Native liaison. The USGS is organized geographically into the Western, Central, and Eastern Regions. The regions work in concert with five scientific disciplines (Biology, Geography, Geographic Information, Geology, and Water Resources) to conduct the scientific mission of the USGS. A list of USGS contacts is provided at the end of this report. 


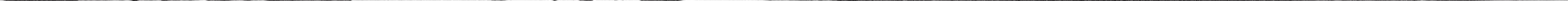




\section{How to Use this Report}

In the following pages, diverse USGS activities related to American Indians and Alaska Natives are grouped into several categories: Highlights of Fiscal Year 2004; Educational Activities; Resource and Environmental Activities; Technical Assistance; General Coordination and Policy activities; and Future Opportunities. If you find an interesting activity that you think might be appropriate to conduct in your area, contact the person(s) listed to learn more about the activity and to find out about other USGS employees who could assist you in developing a similar activity in your area. If you are unsure of what to do, please contact the USGS employees listed in the "USGS Contacts" section of this report. Within the USGS, this report will help our staff develop outreach, educational, and program documents for future use. The report is intended to stimulate USGS employees, American Indians, and Alaska Natives to adapt these activities to new settings and use the USGS contacts to expand collaboration.

This document was prepared by Susan Marcus, USGS American Indian/Alaska Native Liaison, in cooperation with the Regional and Discipline Liaisons:

Gayle Sisler, Eastern Region

Gene Napier, Central Region and Geography Discipline

Cyndee Matus, Western Region

Bonnie Gallahan, Geographic Information Discipline

Kevin Whalen, Biological Resources Discipline

Lynne Sendejo, Office of Equal Opportunity

Sharon Swanson, Geologic Discipline

Glenn Patterson, Water Resources Discipline

The USGS has a Web site dedicated to Native American contacts, activities, and information. Please visit this site at: http://www.usgs.gov/indian/

A general point of contact is Susan Marcus, Director's Office, 703-648-4437; smarcus@usgs.gov 


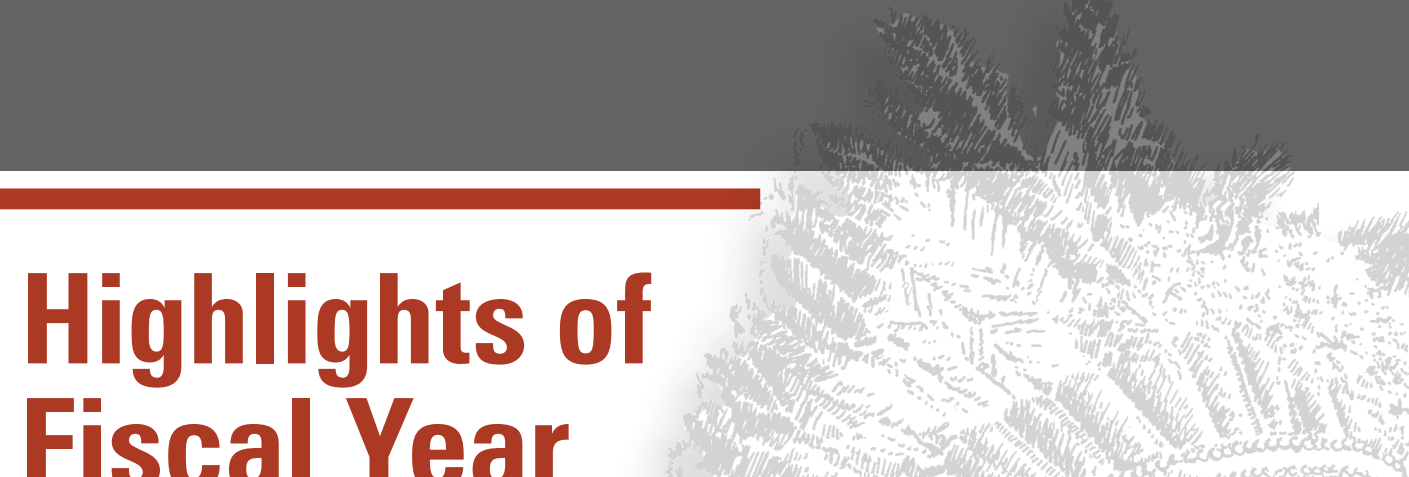
2004

$$
+\cdots+\infty
$$
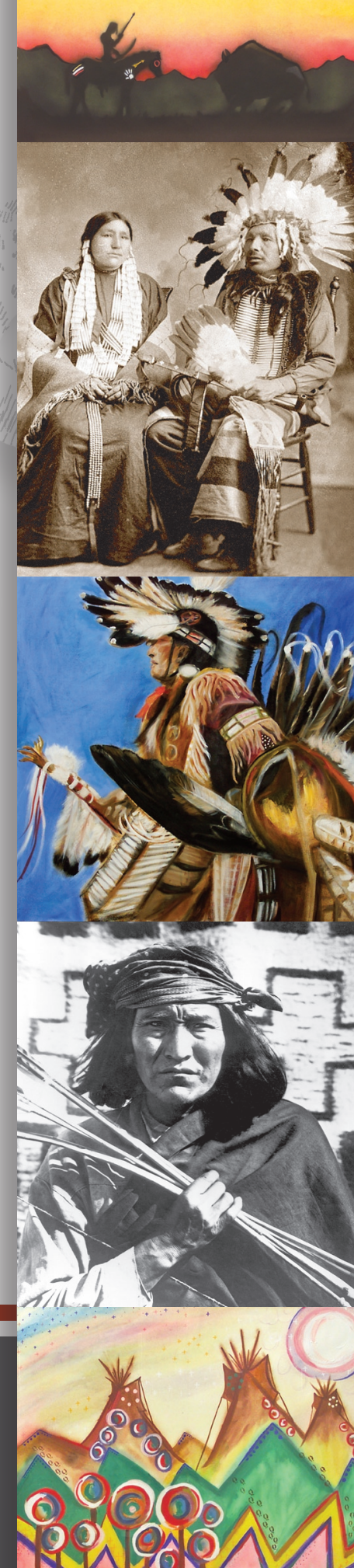


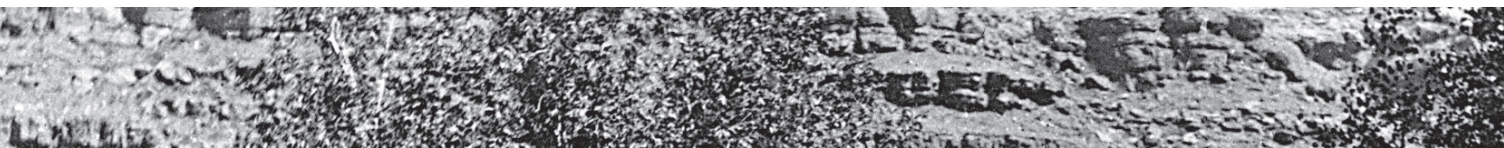

s.t.

L

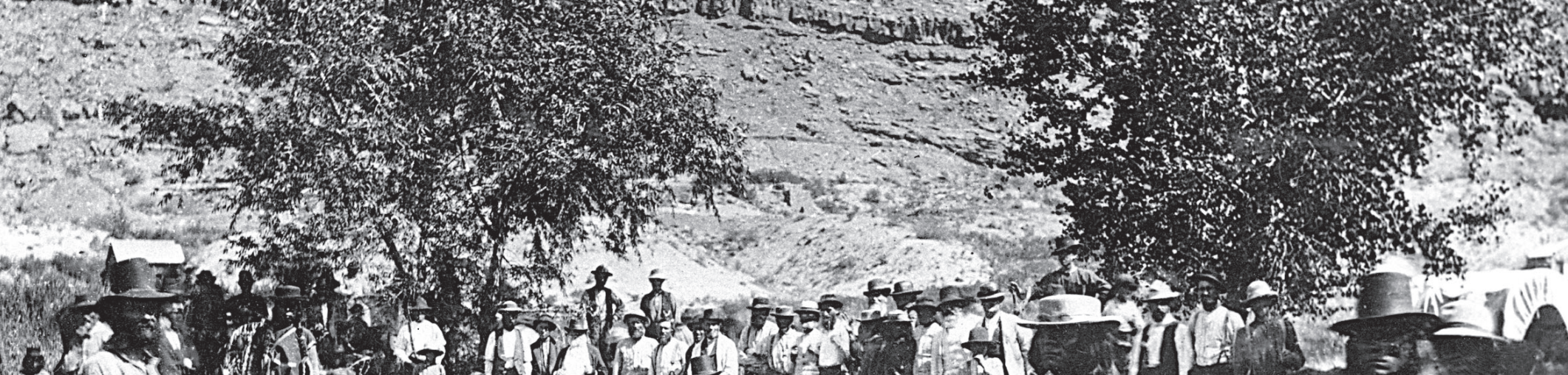

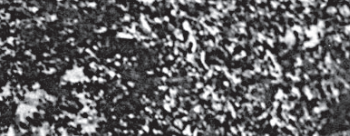

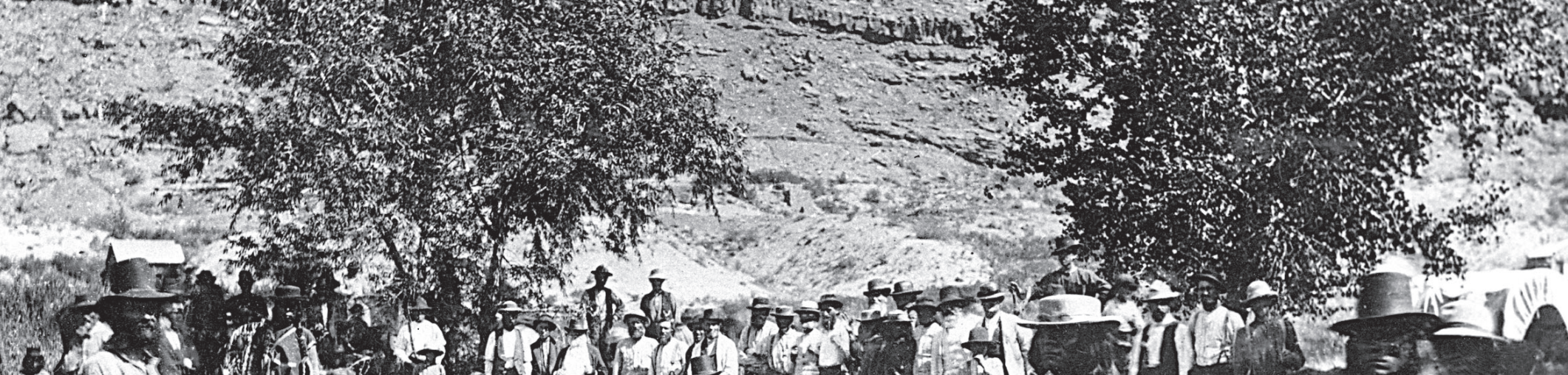

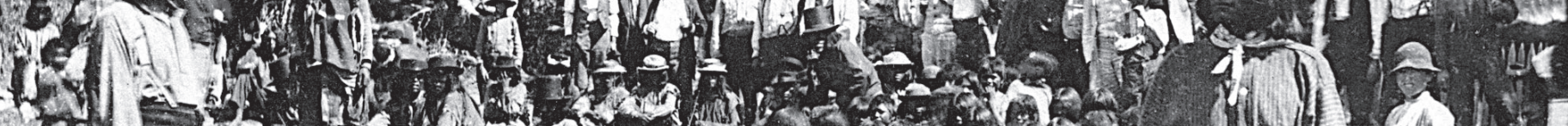

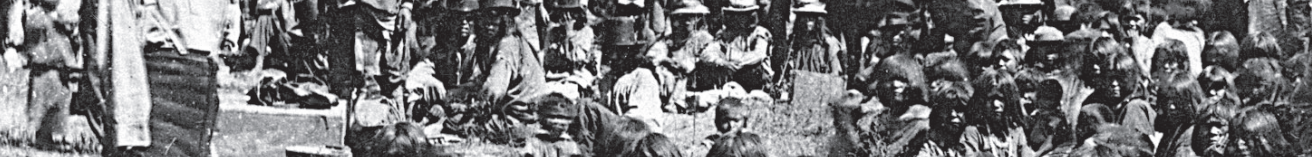

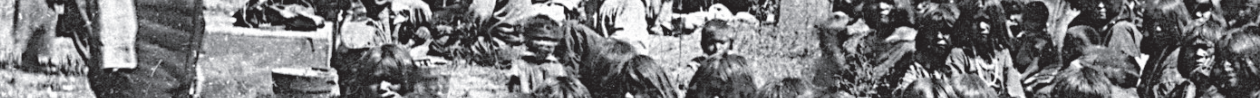

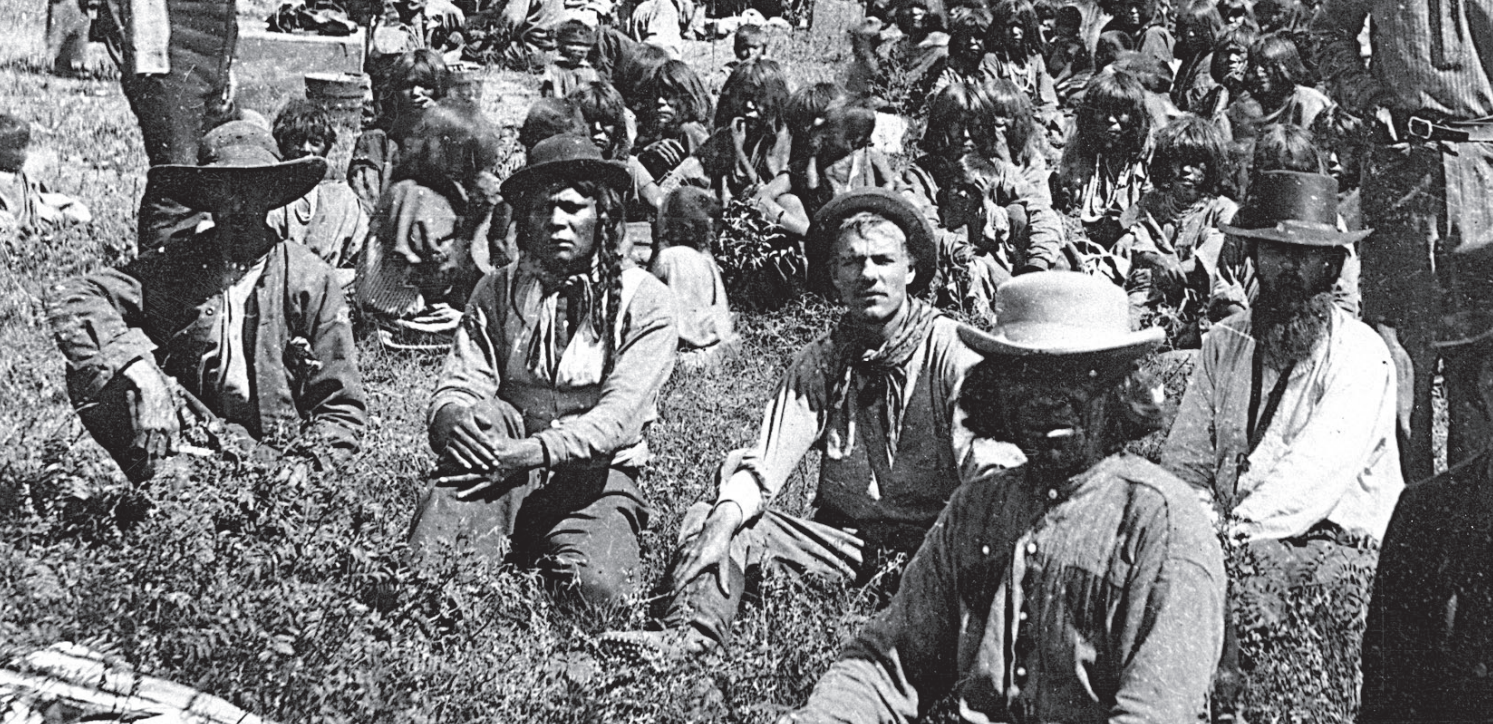



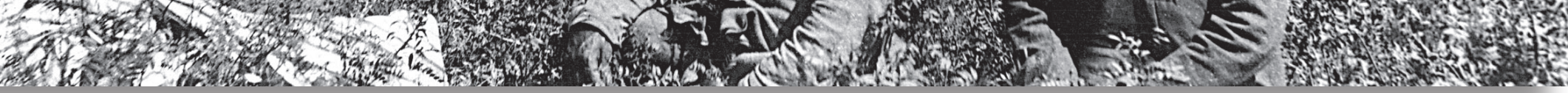

The Powell-Ingalls Special Commission meeting with the Southern Paiutes near St. George, Utah, in 1873. Standing figure at far left is Major John Wesley Powell. USGS Photographic Library; photograph by J.K. Hillers. 


\section{Highlights of Fiscal Year 2004}

\section{Wildlife Health Bulletins and Other Information on Wildlife Diseases}

The USGS National Wildlife Health Center (NWHC) in Madison, Wisconsin, distributes Wildlife Health Bulletins to Federal, Tribal, and State natural resource and conservation agencies, including the Bureau of Indian Affairs. Wildlife Health Bulletins provide and promote an exchange of information on important threats to wildlife health. They are issued for specific wildlife diseases. The Bulletins were issued in 2004 for Hanta virus, Avian Influenza, and Avian Vacuolar Myelinopathy, and the mailing list for the Bulletins was updated to include the Native American Fish and Wildlife Society and other Tribal contacts. The NWHC will continue distributing the Bulletins as they are issued in FY 2005. Tribal governments are encouraged to contact the USGS to be added to the automated announcement list. Contact: Paul Slota, 608-270-2420,paul_slota@usgs.gov

\section{USGS Tribal Relations Training}

During FY 2004, The USGS presented a tribal relations training course in each of the three regions. The course was developed and presented by the USGS Office of Equal Opportunity in cooperation with the Director's Office. The goals of the training were to facilitate USGS interactions with Tribes by informing USGS employees about the unique aspects of Tribal sovereignty; laws, regulations, and policies relating to Native Americans; and some of the cultural issues that may affect relations with Tribal employees. Native Americans were featured during each session, presenting their experiences and perspectives in ways that helped USGS employees understand some of the issues of sovereign, culturally distinct governments and peoples within the United States. The sessions gave all the participants an opportunity to ask questions about etiquette and other issues when working with individual Tribes. Sessions were hosted by USGS offices in Portland, Oregon; Denver, Colorado; and Madison, Wisconsin. USGS employees in other offices joined the Denver session through video conferencing. Contact: Susan Marcus, 703-648-4437,smarcus@usgs.gov or John Szemraj, 703-648-7011, jszemraj@usgs.gov

\section{Chronic Wasting Workshop for the Native American Fish and Wildlife Society}

USGS National Wildlife Health Center (NWHC) employees conducted a 2-day, technical workshop on chronic wasting disease (CWD) for officials and biologists of the Native American Fish and Wildlife Society (NAFWS). The goal of this workshop was to train the CWD coordinators of the NAFWS who will be training the employees of Tribal nations on CWD surveillance and sample collection. The workshop included presentations on ungulate biogeography, populations, and disease; Transmissible Spongiform Encephalopathies; training, manuals, submission forms, and standardized protocols; and surveillance plans and strategies. A tour of the Wisconsin Veterinary Diagnostic Laboratory was conducted to demonstrate how CWD samples are tested; a video was played on sample collection for CWD; and a NWHC laboratory demonstration and hands-on CWD sample collection training took place. Seven NWHC staff members presented detailed information at the workshop. Contact: Kathy Converse, 608-2702445. Kathy_Converse@usgs.gov 


\section{In-Situ Determination of Depth and Temperature Preferences of Great Lakes Fish}

Scientists at the USGS Great Lakes Science Center, Hammond Bay Biological Station, in Millersburg, Michigan, are conducting a study of the daily and seasonal temperature and depth preferences of various types of Great Lakes fish. The data from these studies will greatly increase the understanding of seasonal species overlap and will benefit management and restoration programs in numerous Tribal agencies, U.S. States, Canadian provinces, and other Federal agencies throughout the Great Lakes basin. USGS scientists obtained the fish for the study with assistance from the Chippewa/Ottawa Resource Authority (CORA). The fish are tagged with archival tags that record both depth and temperature, producing daily and seasonal records of the habitats occupied by each fish. During 2004, USGS staff obtained and tagged 79 lake whitefish from Tribal commercial trap nets and six lake whitefish from trap nets set by fishermen from the Sault Ste. Marie Tribe of Chippewa Indians and the Bay Mills Indian Community. The Native American fishermen were under contract with CORA to provide fish for CORA research. Tribal fishermen have also been very responsive in returning fish tags to USGS scientists and in providing parasitic phase sea lampreys for research. Contact: Roger Bergstedt, 989-734-4768, roger_bergstedt@usgs.gov

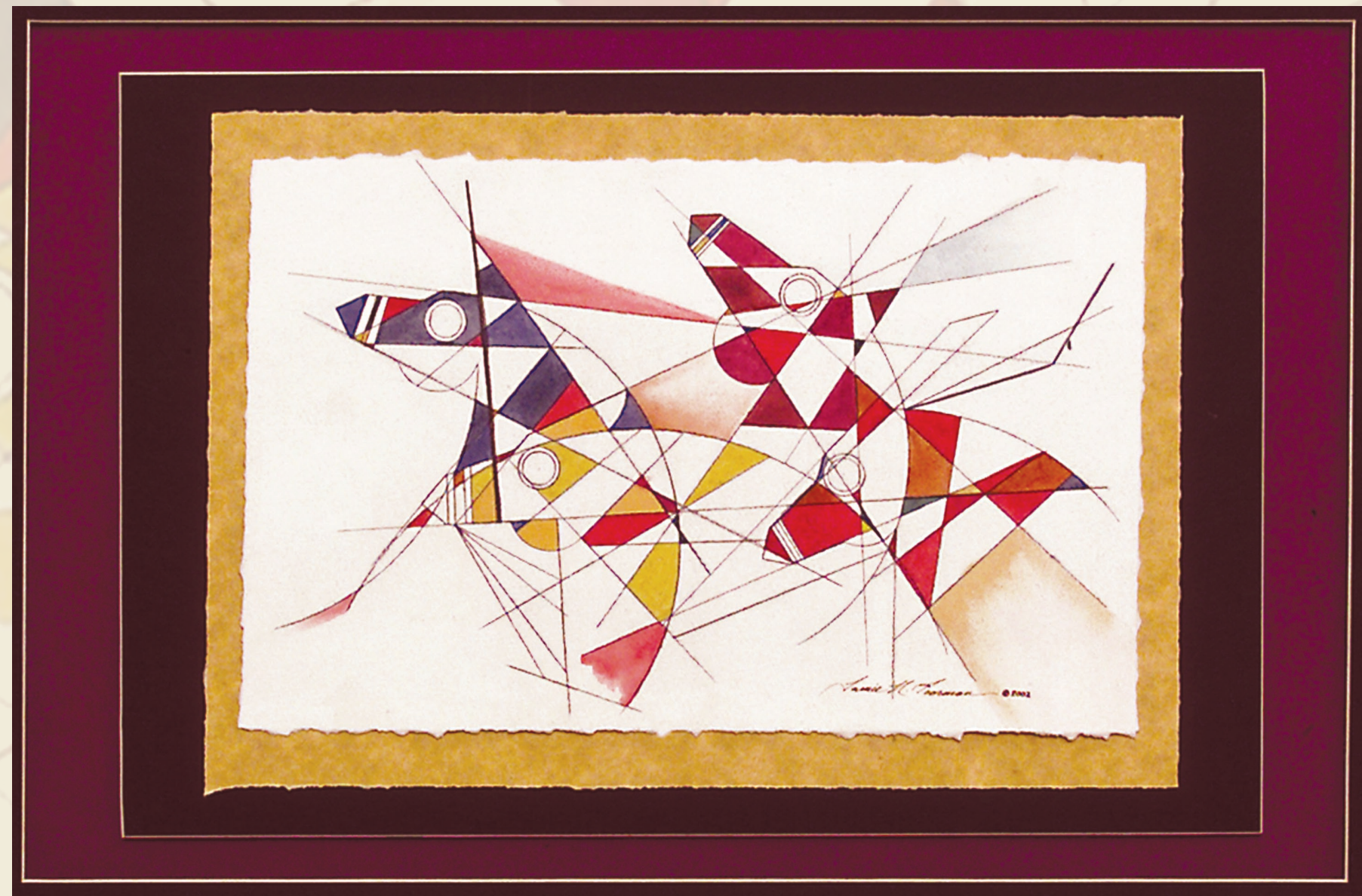

Artwork by Jamie Poorman, Sicangu (Rosebud) Lakota. 


\section{Hydrogeologic Analysis of Current and Future Ground-Water Availability in Chippewa Township, Michigan, Saginaw Chippewa Indian Tribe (Michigan)}

Chippewa Township, in the central Lower Peninsula of Michigan, encompasses tribal lands and buildings belonging to the Saginaw Chippewa Tribe. The Tribe and neighboring communities have a significant need for drinking water, which is obtained exclusively from ground-water wells. The hydrogeology in this area is complex and good-quality water can be difficult to obtain. In an effort to monitor ground-water resources, the USGS installed water-level recorders on two monitoring wells in 2003. In 2005, additional wells will be installed and instrumented with water-level recorders. Contact: Chris Hoard, 517-887-8949, cjhoard@usgs.gov

\section{Public Water Supply Wells, Sault Ste. Marie Tribe of Lake Superior Chippewa Indians (Michigan)}

The Sault Ste. Marie Tribe of Lake Superior Indians and the Indian Health Service discovered the toxic contaminant, ethylene dibromide (EDB) in a recently installed public water-supply well (PWS) at a Tribal housing development during routine testing. Quantities of EDB exceeded U.S. Environmental Protection Agency (EPA) drinking water standards in the well water. In FY 2003, after a series of meetings among Tribal, EPA, Indian Health Service, USGS, and other officials, the USGS assisted EPA in determining whether EDB-contaminated agricultural materials were buried near the PWS wells. The determinations were made using geophysical instruments and a direct-push soil-sampling device. No buried contaminated materials were found. In FY 2004, the USGS provided oversight of test-well drilling at the site and helped design and conduct an aquifer test to determine hydraulic properties of the bedrock aquifer. Analysis of available data indicates that the productive part of the aquifer is a narrow, east-west-trending corridor where the current PWS wells are located. Alternate water sources are being investigated. Contact: Dave Westjohn, 517-887-8921,westjohn@usgs.gov orTom Weaver,906-786-0714, tlweaver@usgs.gov

\section{Mille Lacs Band of Ojibwa and Red Lake Band of Chippewa (Minnesota)}

The Upper Midwest Environmental Sciences Center transferred an assortment of equipment to various Native American governments in the Midwest. Items include two snowmobiles that were transferred to the Mille Lacs Band of Ojibwa Indians and six vehicles and various pieces of office furniture that were transferred to the Red Lake Band of Chippewa Indians. Contact: Randy Hines, 608-781-6398, rkhines@usgs.gov

\section{Alliance of Tribal Tourism Advocates and USGS Sign Agreement (South Dakota)}

The Alliance of Tribal Tourism Advocates (ATTA) and the USGS signed a Memorandum of Understanding (MOU), September 3, 2004, at Eagle Butte, Cheyenne River Sioux Reservation. Robert Cournoyer, President of ATTA, and Thomas Casadevall, USGS Central Region Director, signed the document for their respective organizations. The objectives of the partnership are to leverage USGS and ATTA resources to strengthen ATTA's natural science capabilities to assist their member Tribes in educational and community development. Activities conducted through the agreement include applying geospatial and earth science information to community based issues while respecting Tribal approaches, values, and traditions. The partnership will ensure that this information is disseminated to the Tribes through channels that will optimize its potential value and use to Native American communities. Contact: Gene Napier, 605-594-6088,enapier@usgs.govor Daphne Richards-Cook,605-341-2382,dcook.atta@ midconetwork.com 


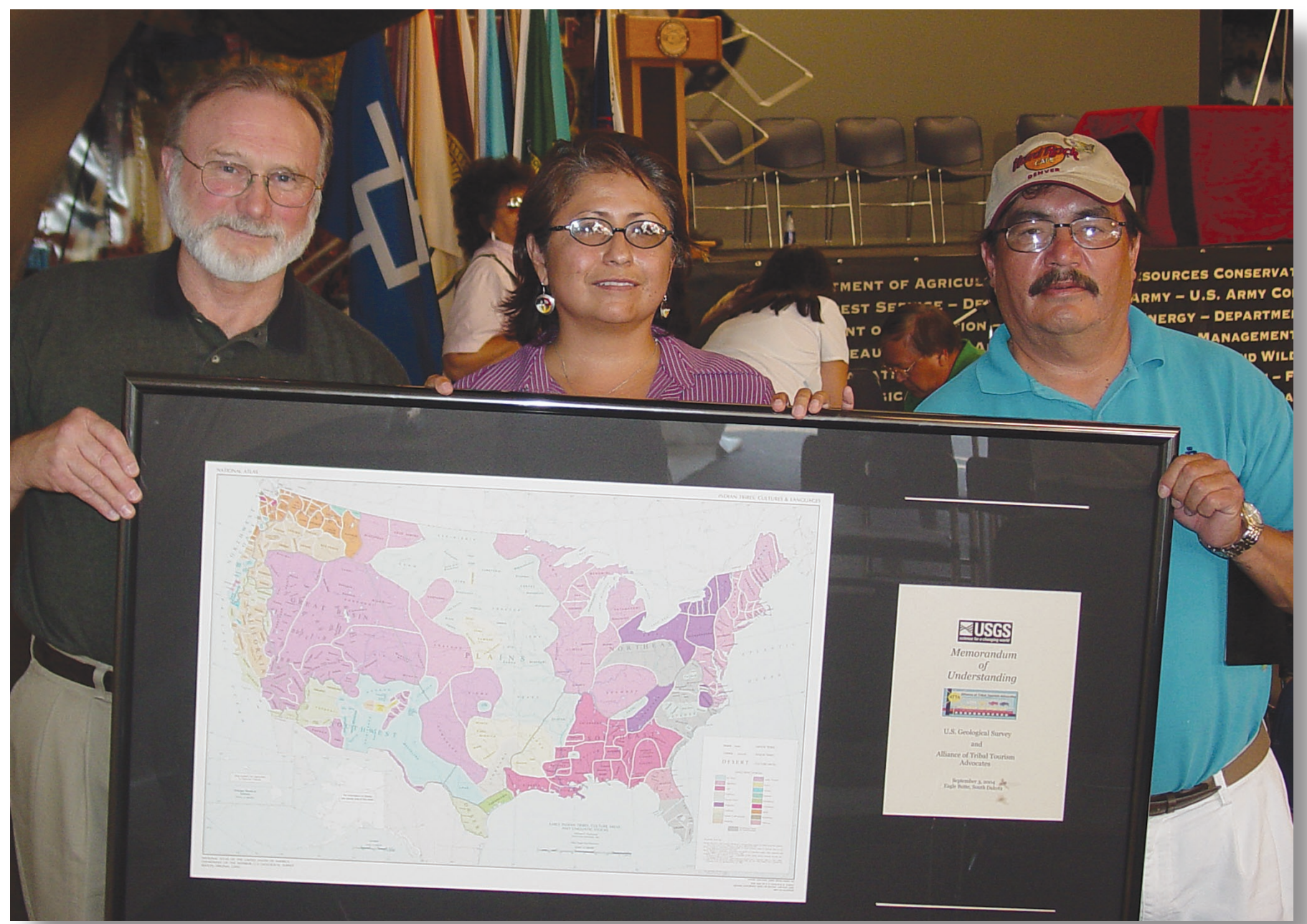

Gene Napier (USGS) and Alliance of Tribal Tourism Advocates (ATTA) representatives Daphne Richards-Cook (Executive Director) and Robert Cournoyer (President) celebrate the signing of an agreement between ATTA and USGS. Photograph by Myrna Leader Charge, Rosebud Sioux Tribe, ATTA representative.

\section{Supporting Yankton Sioux Pesticide Management Plan (South Dakota)}

The USGS, in cooperation with the U.S. Environmental Protection Agency, completed a compilation and analysis of data to provide background information for a Pesticide Management Plan for the Yankton Sioux Tribe. Numeric and geospatial datasets include: pesticide use in the area, pesticide concentrations in surface water, topographic data, geohydrologic features, land cover and land use, precipitation, irrigation, and orthophotographs. The report is available online at http://water.usgs.gov/pubs/ of/2004/1032. The Yankton Sioux Tribe will use the assembled information to develop a Pesticide Management Plan for their lands. Contact: Bryan Schaap, 605-352-4241, bdschaap@usgs.gov

\section{Outreach in the Sioux Falls Schools, Native American Connections Class (South Dakota)}

Throughout FY 2004, a USGS contractor working for Science Applications International Corporation (SAIC) at the USGS National Center for Earth Resource Observation Science (EROS) in Sioux Falls, South Dakota, made weekly visits to a classroom in Sioux Falls to mentor Native American students. Many of the kids lack positive role models and are at high risk for dropping out of school. By supporting his work, the USGS and EROS, showed their commitment to the future of these young people. The USGS contractor prepared lesson plans that were relevant and interesting to the youth. In addition, he talked about the mission of EROS and the USGS and what education and skills were needed to work for those agencies. Contact: Michael Choate, 605-594-2829, mchoate@usgs.gov 
Mountain peak about 8 miles south of Indian Wells, Navajo Indian Reservation, Navajo County, Arizona. The horizontally banded slopes are composed of sandstone of the Wingate Sandstone, and dark basaltic rock caps the mountain. USGS Photographic Library; photograph taken in 1957 by J.W. Harshbarger.

\section{Southwest Strategy}

The USGS is an active partner in the Southwest Strategy (SWS). SWS is an intergovernmental process that provides a forum for diverse entities to collaborate and resolve natural resource conservation, management, and community development issues affecting Arizona and New Mexico. Through cooperative planning and improved decision making, SWS strives to maintain, restore, and enhance the cultural, economic, and environmental quality of life for the people of Arizona and New Mexico. SWS brings together Federal, Tribal, State, and local governments, as well as private landowners and other stakeholders, in a problem solving process. USGS continues to sponsor the SWS Tribal Relations Support Team (TRST). The TRST brings together Federal, Tribal, and State managers to build relationships and identify mechanisms for working together. Contact: Randy Updike, 303-236-5440, updike@ usgs.gov or Wes Ward, 520-670-5584,wward@usgs.gov

\section{Navajo Nation and USGS Sign Official Approval for Human Health/ Coal Research (Arizona, Colorado, New Mexico)}

The Navajo Nation officially approved a USGS research project titled: "Relationship of Indoor and Ambient Air Quality to Respiratory Diseases in the Navajo Nation.” Groups participating in negotiating the agreement and expected to participate in the future research include the USGS, the Navajo Nation Environmental Protection Agency, the Navajo Nation Division of Health, Diné College, the Indian Health Service, the Shiprock Chapter of the Navajo Nation, the Navajo Nation Historic Preservation Department, and the Navajo Tribal Utility Authority. Funding to support Navajo collaborators on the project has been secured from the U.S. Department of Energy and the Agency for Toxic Substances and Disease Registry (U.S. Department of

Health and Human Services). This research project is particularly important because it will examine connections between residential and industrial coal usage by

Navajo people and health issues. Results of the study will provide information that will assist the Navajo Nation in developing policies and practices to improve healthful use of this energy source for the benefit of their people. Contact: Joe Bunnell, 703-648-6497, jbunnell@usgs.gov

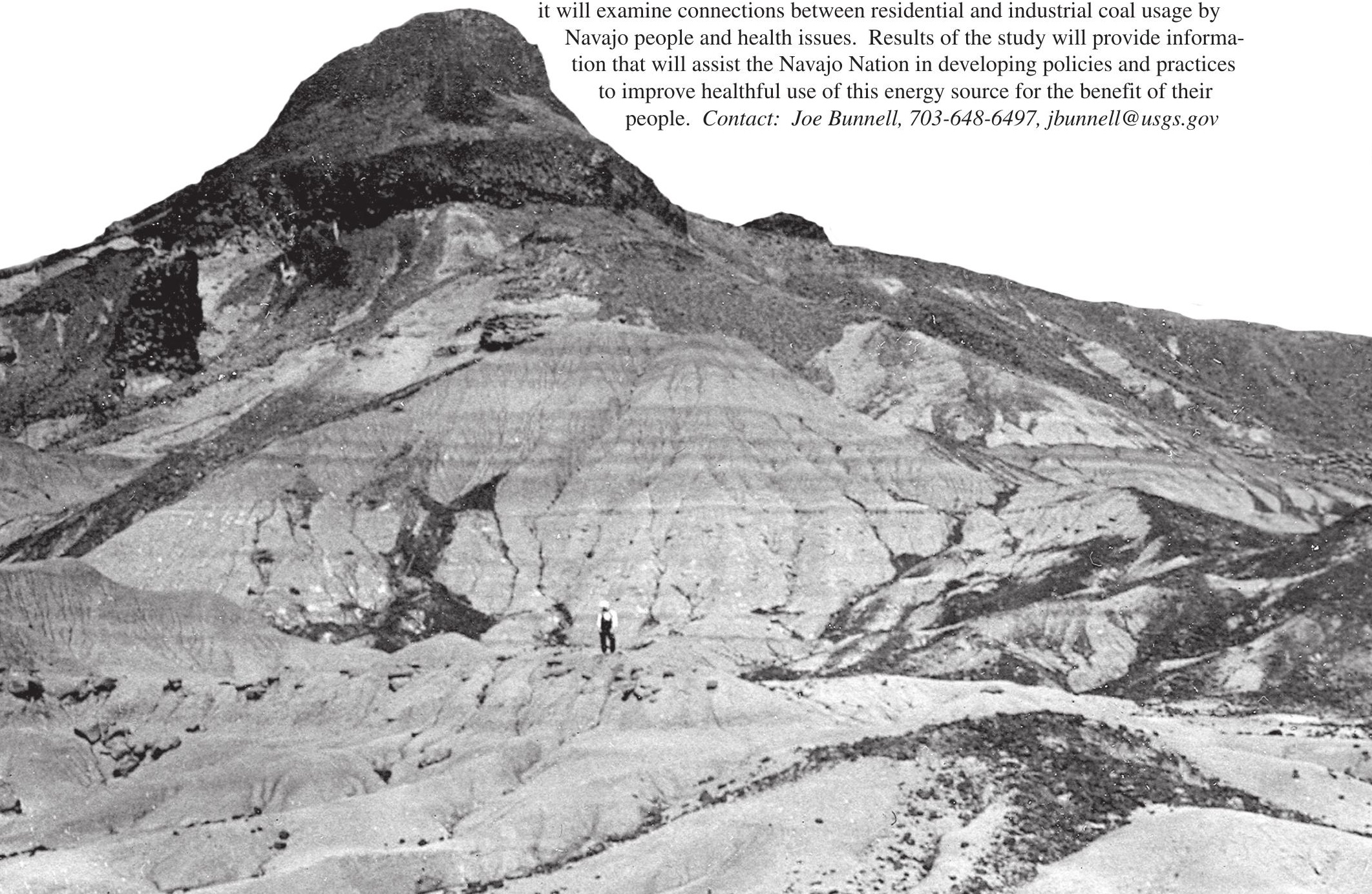




\section{Strontium-Isotope and Trace-Element Sourcing of Pre-Hispanic Maize from Chaco Canyon, Navajo Nation (Arizona, Colorado, New Mexico)}

The Navajo Nation's Office of Historic Preservation wants to determine (1) the source of maize consumed by pre-Hispanic American Indians that occupied Chaco Canyon, New Mexico, and (2) the pre-historic productivity of the Chaco Canyon core area. USGS scientists from the Arid Regions Climate Project are cooperating with the Navajo Nation and the National Park Service by examining strontium in water and in mice. The chemistry of the mice bones will help characterize the strontium isotope composition of the fields in and near the canyon. The mice range over a few to several hundred yards, and they eat plants and insects that extract strontium from the soils, so the mice bones integrate the strontium isotope signature from a fairly wide area. The scientists use the strontium isotopic composition of waters absorbed through the soil into the plants to determine field sites where ancient corn was grown. The mice should provide better information on the composition from an integrated area as opposed to taking a few discrete soil samples. Contact: LarryBenson, 303-541-3005, lbenson@usgs.gov

\section{Dating Alluvial Fans and Pre-Columbian Cornfields in the Española Area, New Mexico, Near San Juan Pueblo (Ohkay Owingeh)}

Scientists from the USGS Luminescence Dating Laboratory in Denver, Colorado, and the BIA in Albuquerque, New Mexico, formed a collaborative partnership to attempt to date alluvial fan development in a small, unnamed arroyo just north of Española, New Mexico, by using Optically Stimulated Luminescence (OSL). Cornfields created by pre-Columbian tribes were discovered on and within the fans. Water appeared to have been diverted to terraces for use in growing corn, and several fallow periods were noted in the fields by episodes of eolian sand deposition. The exact periods of occupation were not known, due to the dearth of pottery and suitable organic remains at the site. Use of OSL to directly date the last time the eolian sediment was exposed to sunlight before being buried helped determine an age on the timing of the fallow periods. During field collection of the samples in August 2003 several members of the San Juan Pueblo (Ohkay Owingeh) joined the scientists to view the trenches and sampling techniques and to learn about the science involved. Ages of the oldest periods of occupation were about 705 years ago (radiocarbon) to possibly 1,740 years ago (OSL ages to be confirmed), and the youngest periods of occupation were about 555 to 565 years ago. Contact: Shannon Mahan 303-236-7928, smahan@usgs.gov or Chris Banet, 505-563-3403, cebanet@msn.com

\section{Scientific Plan to Assess Pacific Northwest Tribal Water Resources}

Native American governments in western Washington need comprehensive water data in order to protect, restore, and manage their water resources. To understand the factors affecting water quality and quantity on a regional scale, the data must be collected and managed through a systematic, coordinated approach. To help the Northwest Indian Fisheries Commission (NWIFC) design a coordinated scientific plan for Tribal studies of the impacts of environmental factors on water resources and habitat, the USGS is providing the NWIFC with guidance for Tribal water and habitat studies. This project will result in a written report. Contact: Chris Konrad,253-428-3600,ext.2634, cpkonrad@usgs.gov

\section{Pacific Northwest Earthquake and Tsunami Hazards (Washington)}

A USGS earthquake specialist met representatives of the Quileute Nation and the Makah Nation at tsunami and earthquake hazards workshops in Clallam County, Washington. The workshops were sponsored by State and county emergency management agencies and featured information about potential earthquake and tsunami hazards as well as public safety measures and methods. The British Broadcasting Corporation recorded some of the workshop proceedings to use in a documentary on Cascadia earthquake hazards. Contact: Brian Atwater, 206553-2927,atwater@usgs.gov 

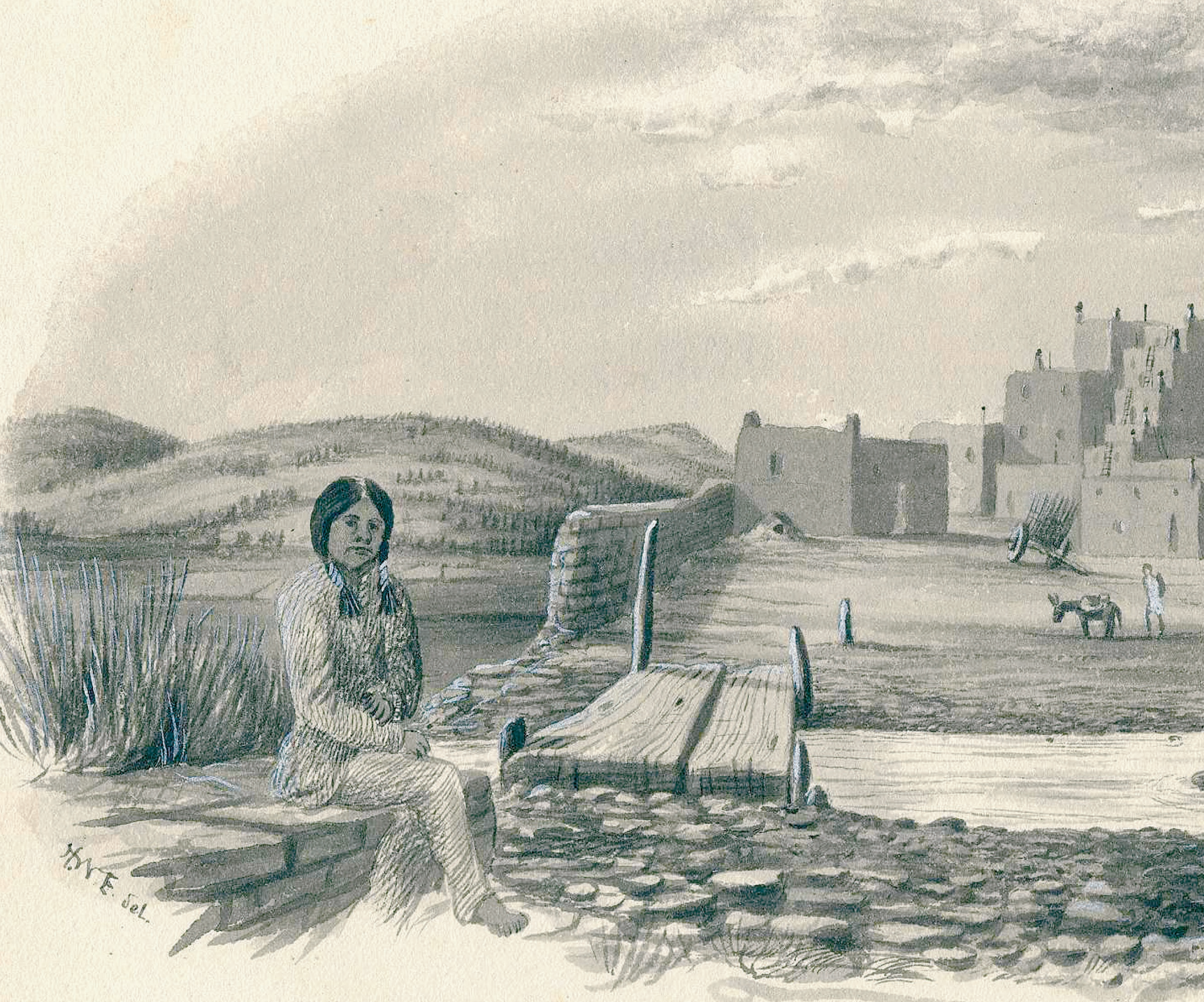
Taos Pueblo as depicted by Henry W. Elliott in a drawing dated September 13,1869 . These remarkable dwellings are thought to have appeared before 1400. Taos Pueblo is a U.S. World Heritage site, a distinction shared by less than 30 sites in the U.S. Henry W. Elliott was an artist employed by the F.V. Hayden survey. The Hayden survey was combined with the King, Powell, and Wheeler surveys in 1879 to form the U.S. Geological Survey. USGS image courtesy of Kevin C. McKinney.

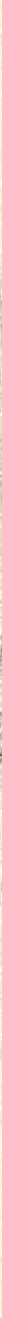




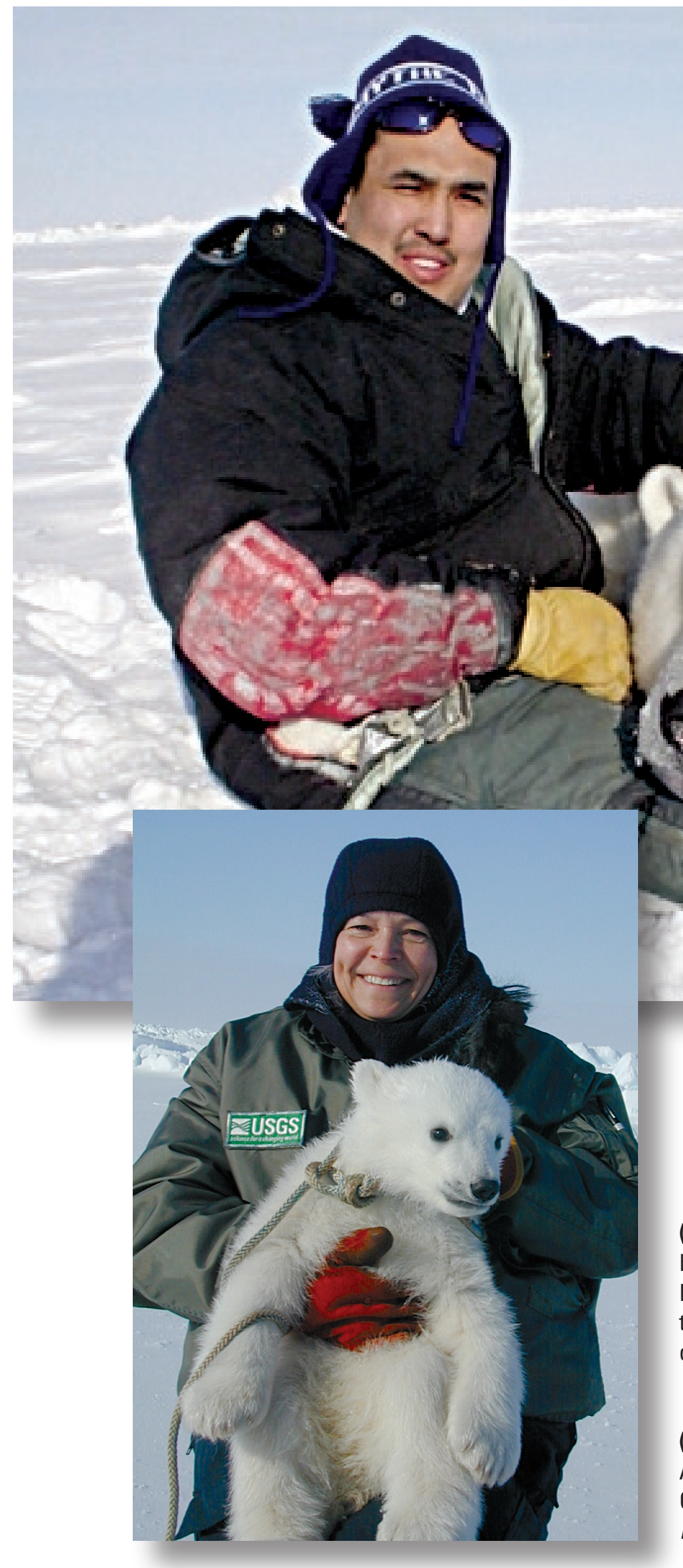

(Above) Tommy Olemaun (Alaska Native), subsistence biologist with the North Slope Borough Department of Wildlife Management in Barrow, Alaska, works with a temporarily tranquilized bear. He worked with the USGS as an aerial spotter during polar bear captures. Photograph by George Durner, USGS.

(Left) Lia Parker, who works for Southcentral Foundation in Anchorage (and is part Chippewa), holds a polar bear cub. Capturing a polar bear family was part of a USGS project. Photograph by George Durner, USGS. 


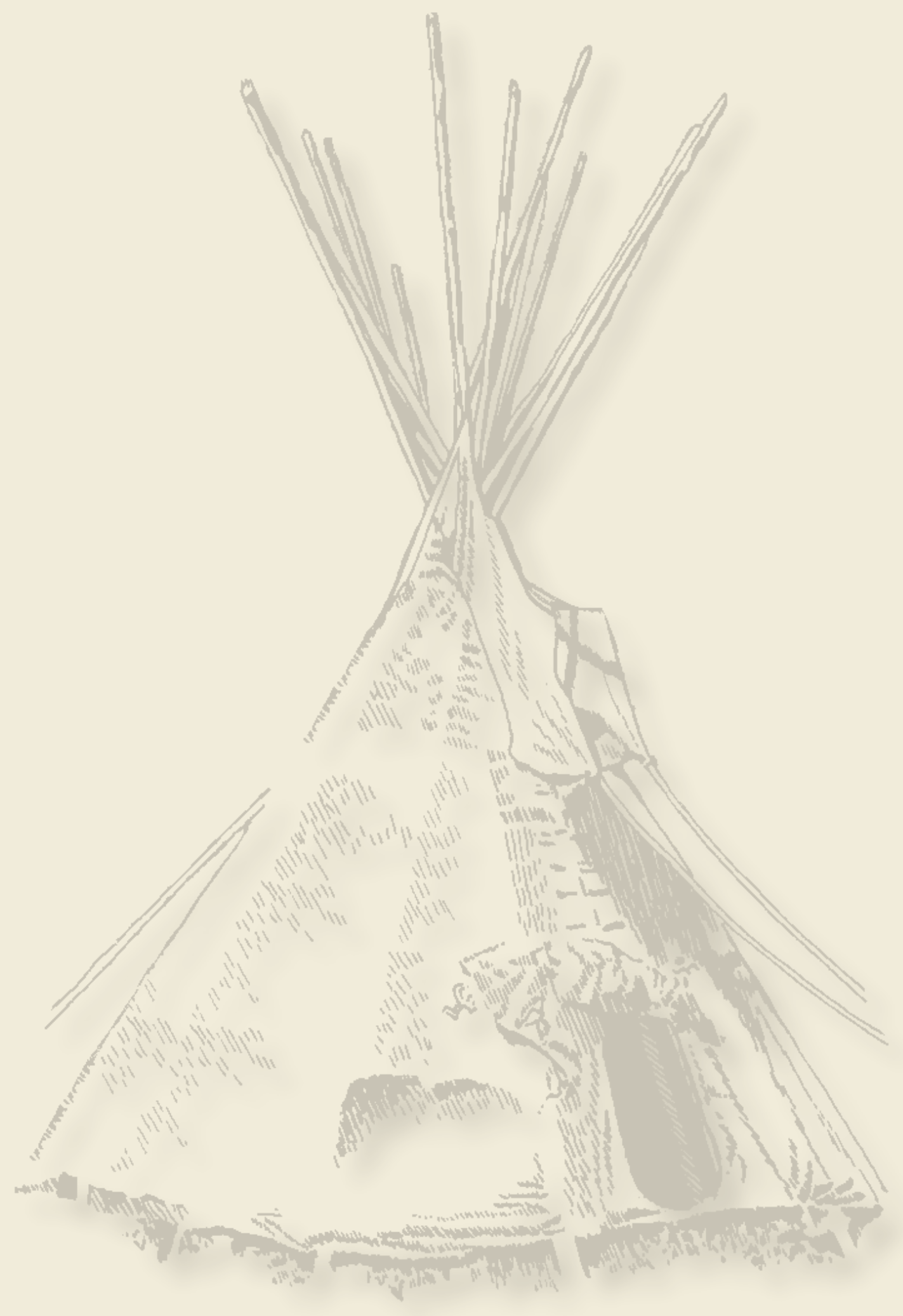




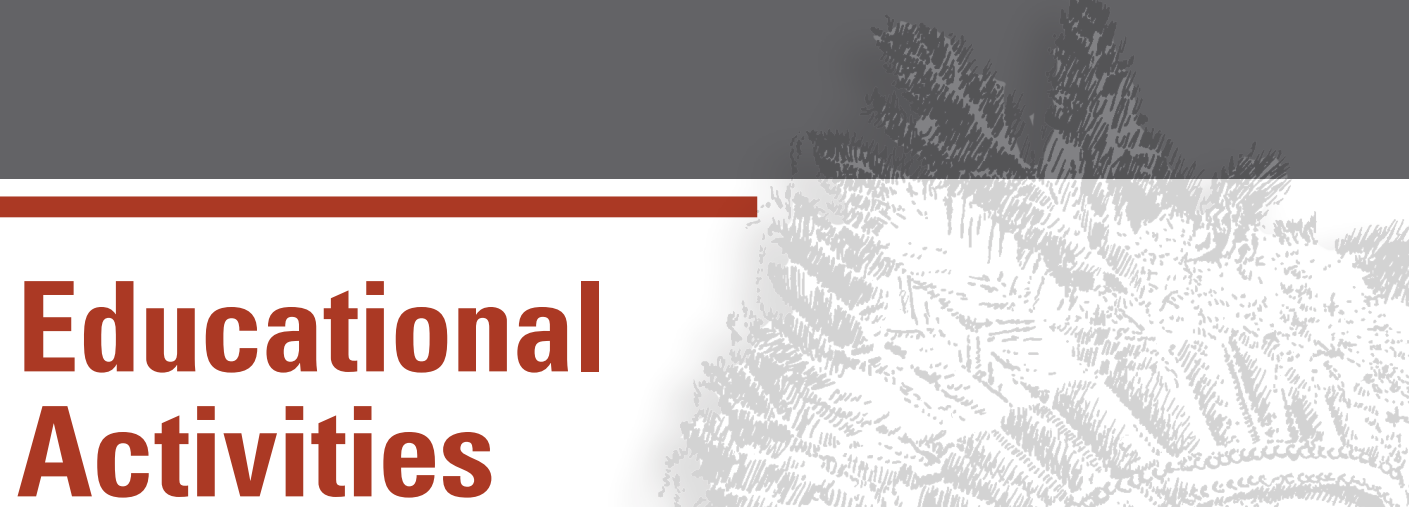

$$
\text { to } 4 \text { का }
$$
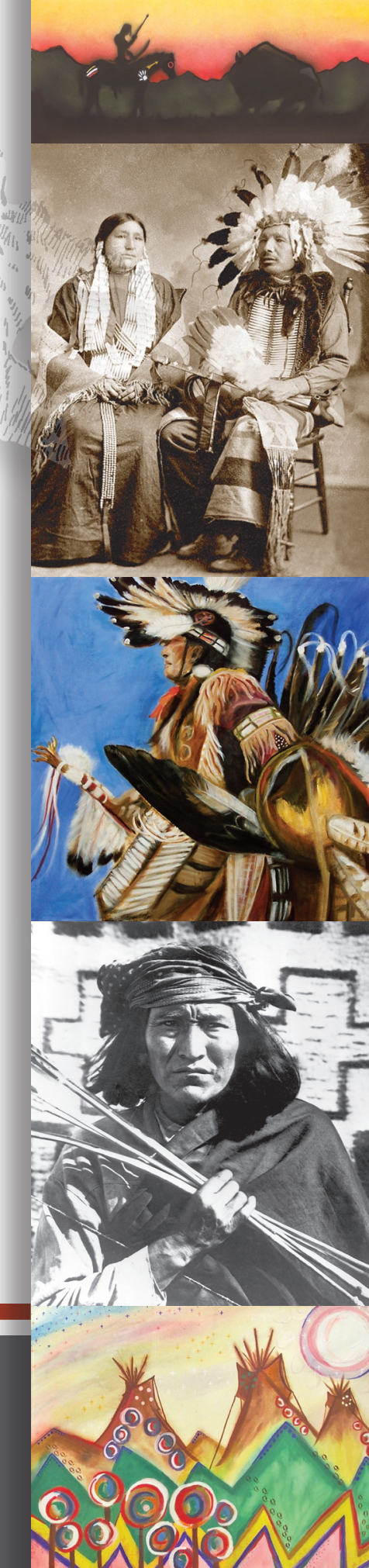


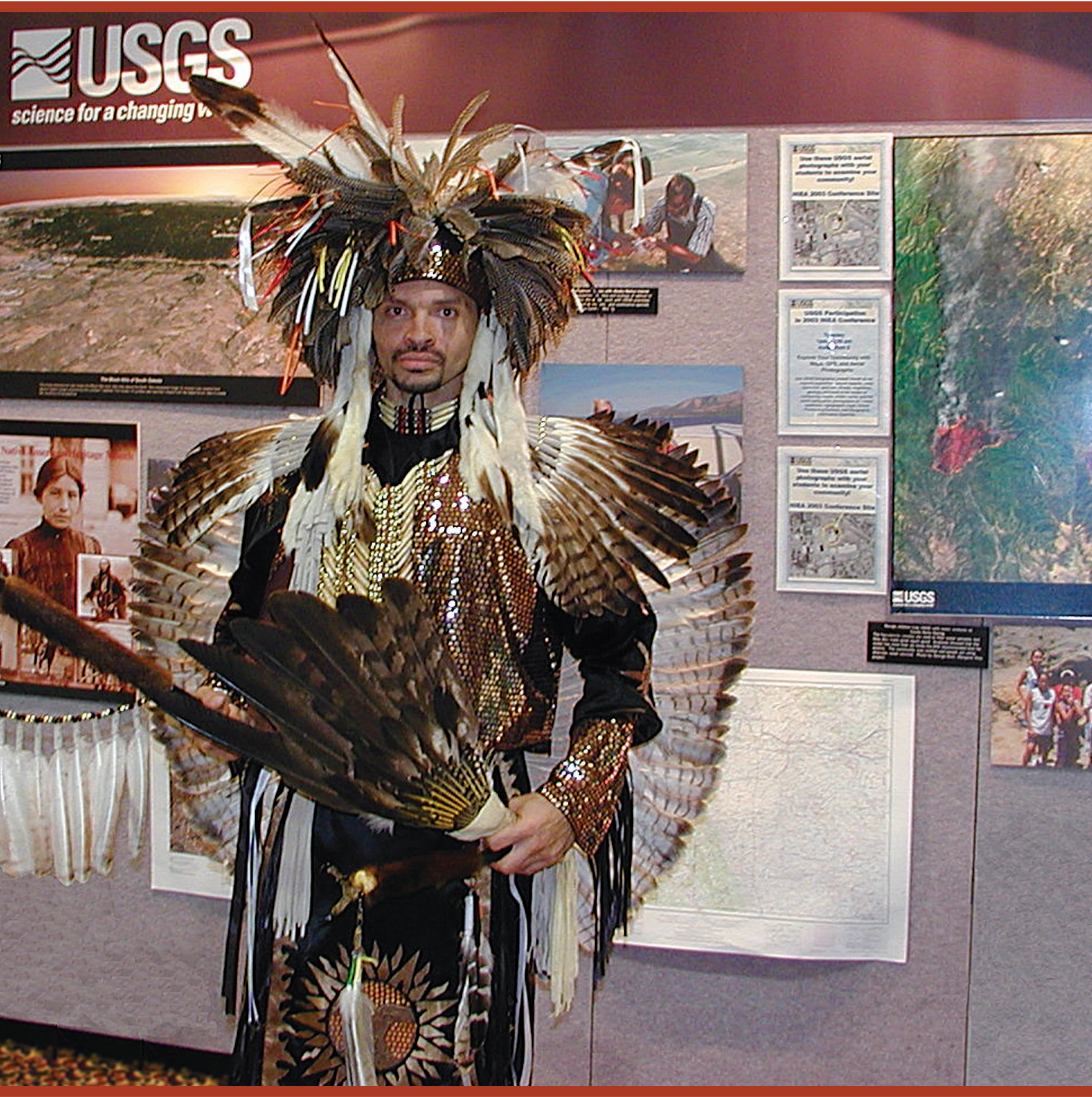




\section{Educational Activities}

\section{National Indian Education Association}

The USGS continued to expand its involvement in the annual conference of the National Indian Education Association (NIEA) by providing a hands-on mapping workshop. Participants in this workshop, conducted by a USGS geographer, explored how to use USGS maps, aerial photographs, and satellite images to teach and learn about Native American population distribution, landforms, river systems, history, natural hazards, land use, and biodiversity. Emphasis was placed on how students can use these resources in history, geography, economics, environmental studies, cultural studies, and science classes to analyze patterns and linkages from a local to a global scale to encourage critical thinking. The USGS also hosted an exhibit at the NIEA conference in Greensboro, North Carolina, which attracted over 3,000 attendees. USGS staff distributed maps, teaching materials, and information. For the full report and photographs, see http://rockyweb.cr.usgs.gov/outreach/reports/niea03t.pdf Contact: Gene Napier, 605-5946088, enapier@usgs.gov or Joseph Kerski,303-212-4315, jjkerski@usgs.gov

\section{National Oceanic and Atmospheric Administration Coastal GIS and Metadata Training for American Indians}

The National Oceanic and Atmospheric Administration (NOAA) and the USGS, through its support of the Federal Geographic Data Committee (FGDC), presented an annual training session on GIS/metadata and coastal issues for American Indians at the USGS Training Center in Denver, CO. Topics include the National Spatial Data Infrastructure, water quality, and flora and fauna monitoring. The training session helps assure Tribal investment in data collection and maintenance and provided Tribal access to public data catalogs and clearinghouses. The course accommodates 15-20 American Indian students at each session. Contact: Bonnie Gallahan, 703-648-6084, bgallahan@usgs.gov

\section{Water Technician Training Course}

The Bureau of Indian Affairs sponsored its annual Water Technician Training Course sessions in Las Cruces, New Mexico, and in Fairbanks, Alaska. Tribal representatives from throughout Indian Country participate in the course. Twenty-seven students participated in the New Mexico session. The four-week earth sciences session was coordinated by New Mexico State University utilizing instructors from several Federal agencies and academia. USGS personnel taught a three-day module entitled, "Introduction to Hydrologic Data Collection Techniques." Instruction included classroom and field activities on ground-water concepts and data collection, as well as surface-water data-collection techniques. The field-oriented training program is based on hands-on experience to develop basic data collection skills. The Alaska session was held during July 2004 in Fairbanks, Alaska, as part of a two-week course coordinated by the University of Alaska, Fairbanks. The USGS provided three days of classroom training in surface-water hydrology, water quality, and ground-water monitoring techniques to about 15 Alaska Natives from the Yukon River basin. Contact: Steven Frenzel (Alaska), 907-786-7100, sfrenzel@usgs. gov or Edward (Nick) Nickerson (New Mexico), 505-646-7618, nickerso@usgs.gov

(Facing Page) Native dancer at the USGS exhibit at the 2003

National Indian Education Association (NIEA) conference,

Greensboro, North Carolina. Photograph by Susan Marcus, USGS. 


\section{Introduction to Metadata and GIS Courses for American Indian Conservation Professionals}

The USGS, through its support of the Federal Geographic Data Committee (FGDC), and the U.S. Fish and Wildlife Service (FWS) continue to offer two training sessions that introduce American Indian students to the uses of GIS. The Native American students include Tribal, State, and Federal employees. Topics of the sessions include the National Spatial Data Infrastructure, Geospatial One Stop, The National Map, metadata, spatial data themes and layers, constructing queries, and cartographic principles. The sessions offer best practices used and describe the effect of scale on mapped data. The courses are offered several times per year at the FWS National Conservation Training Center in West Virginia. Contact: Bonnie Gallahan, 703-648-6084,bgallahan@usgs.gov

\section{Ho-Chunk Nation Students (Wisconsin)}

In July 2004, a USGS Upper Midwest Environmental Sciences Center scientist gave a tour of the Center's science and educational resources to two teachers, five parents, and 20 students from the Ho-Chunk Nation's La Crosse Study Center in La Crosse, Wisconsin. The Study Center is sponsored by the Ho-Chunk Nation to facilitate Native American educational success in the La Crosse public school system. The first through eighth grade students in this summerschool program learned of USGS science and career opportunities, and they had the opportunity to touch live invasive and native species of fish. USGS scientists also explained the relevance of unbiased USGS science to preservation of natural resources and to Native American cultural values. Contact: Randy Hines, 608-781-6398, rkhines@usgs.gov

\section{USGS and South Dakota School of Mines and Technology Collaborate on Native American Student Summer Camp (South Dakota)}

The USGS, through an Earth Resources Observation \& Science (EROS) staff person stationed at the South Dakota School of Mines \& Technology (SDSM\&T), Rapid City, South Dakota, worked with 15 Native American students in the Wind Cave National Park area during 2004. The group used Global Positioning System (GPS) units as a part of SDSM\&T advanced placement program for gifted students. The USGS staffer showed the students how remote sensing technology can be used in many earth science applications including fire science. Contact: Gail Schmidt, 605-394-2292, gschmidt@usgs.gov

\section{USGS EROS Supports Sinte Gleska University Tribal Rangeland Management Project (South Dakota)}

Under a NASA Earth Science Research, Education, and Applications Solutions Network Cooperative Agreement Notice (REASoN CAN) grant awarded to Sinte Gleska University (SGU), the USGS National Center for Earth Resources Observation \& Science (EROS) is collaborating and providing support to the project entitled, "Using Geospatial Information to Enhance Tribal Rangeland Management Through Education and Understanding." Building on an existing USGS-SGU Memorandum of Understanding for cooperative activities, USGS EROS provides geographic information systems (GIS) and applied science support to this planned multi-year project. The goals of this effort are to understand the impact of tribal rangeland management practices on vegetation resources utilizing GIS tools and applied science. A second key goal is to educate and engender practical management applications to benefit the tribal community and resource managers in economic capacity building and enhanced stewardship of tribal lands. Fiscal years 2004 and 2005 activities focused on the development of rangeland observational components, including satellite and aerial remote sensing and ground field measurements. Included within this effort is the implementation of GIS-ready Nexrad meteorological data sets for incorporation into a rangeland production model. Contact: Eugene Napier,605-594-6088,enapier@usgs.gov or David Meyer,605-594-6046.dmeyer@usgs.gov 

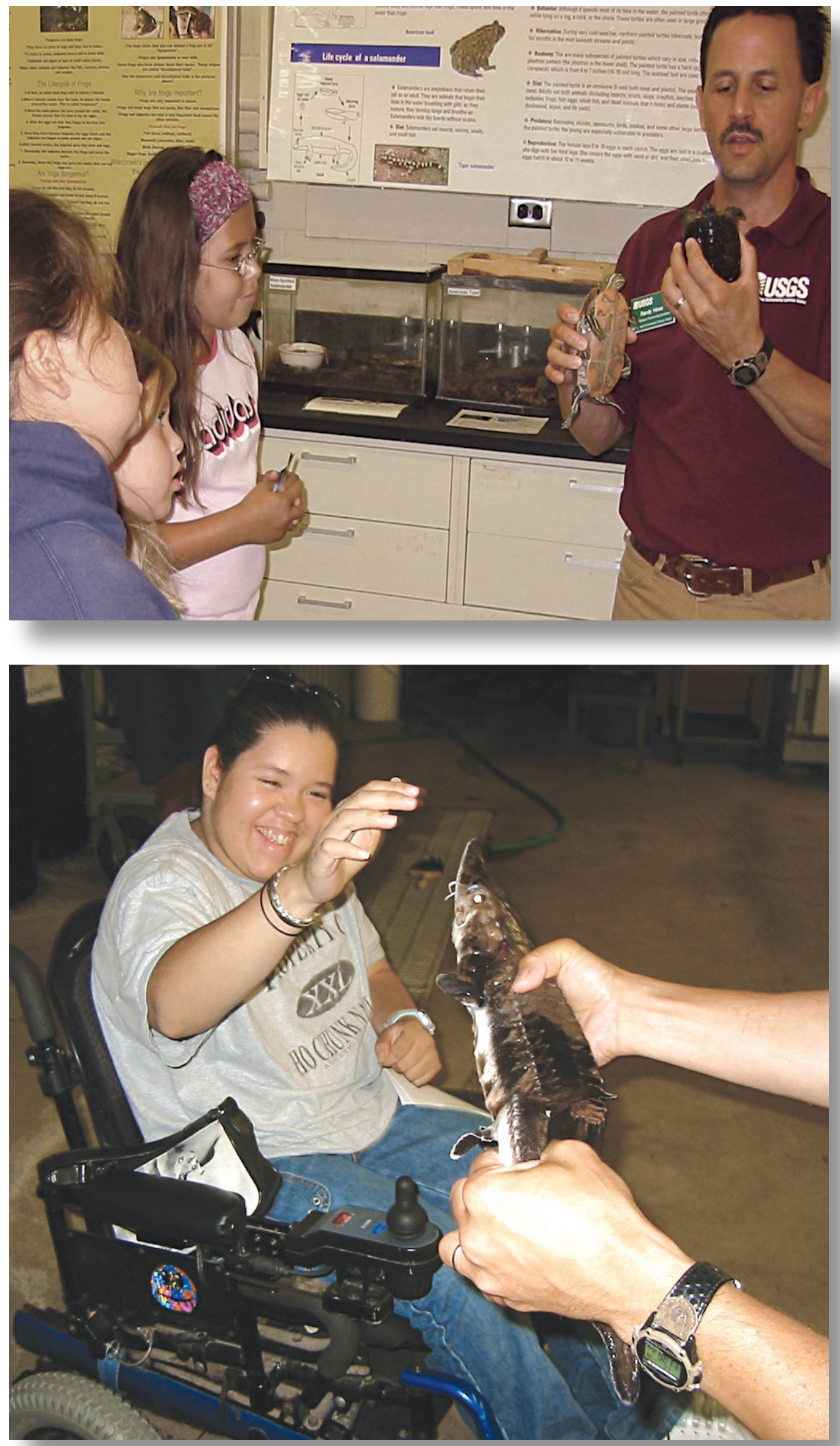

Randy Hines, USGS, talks to Ho-Chunk students about research at the USGS Upper Midwest Environmental Sciences Center, La Crosse, Wisconsin. Photograph by Bob Kratt, USGS.

A Ho-Chunk student learns about USGS sturgeon research at the USGS Upper Midwest Environmental Sciences Center, La Crosse, Wisconsin. Photograph by Bob Kratt, USGS. 


\section{Science Impacts (South Dakota)}

The USGS National Center for EROS is supporting the Indigenous Knowledge Center for Education and Science Impacts (IKCE SI) at Sinte Gleska University (SGU). IKCE SI, a collaboration between SGU and the USGS, is developing a framework for using indigenous knowledge in natural and social sciences to view human activities as an integral part of nature. The first year of the collaboration will use Northern Plains indigenous life ways to develop methods and tools that can be extended across North America and ultimately to indigenous cultures around the world. The project will evaluate the social memory learning tools required to translate indigenous views of the landscape into scientific descriptors. Another effort is to develop knowledge management tools; for example, identifying methods to "record" things like oral histories that intrinsically resist being recorded. Ultimately, these tools will be used by the USGS to improve scientific research and communication of research results. Contact: David Meyer,605-594-6046,dmeyer@usgs.gov

\section{Enhancing Earth Science Curricula at Sinte Gleska University (South Dakota)}

This collaborative effort continued into its second year, providing expertise from across USGS disciplines to augment Sinte Gleska University's earth science curricula and resource management activities within tribal agencies. FY 2004 topics included water resource management, alternative energy resource development, and cultural resource preservation. USGS collaboration is part of a Central Region Integrated Science Project (CRISP). Contact: David Meyer, 605-594-6046, dmeyer@usgs.gov

\section{Information Technology Infrastructure to Sinte Gleska University (South Dakota)}

USGS Water Resources personnel conducted a workshop for Sinte Gleska University (SGU) professors and students and local high school teachers and students in May 2004. Participants were trained to use the National Water Information System (NWIS) online database and to integrate the data from this and other sources into a GIS. In addition, possible grant mechanisms for Tribal colleges to strengthen their earth science programs were researched and provided to SGU professors. USGS Water staff met with key SGU and Rosebud Sioux Water Resources Department staff on several occasions to discuss ways to develop a hydrologic information partnership. Contact: Janet Carter, 605-394-3215,jmcarter@usgs.gov

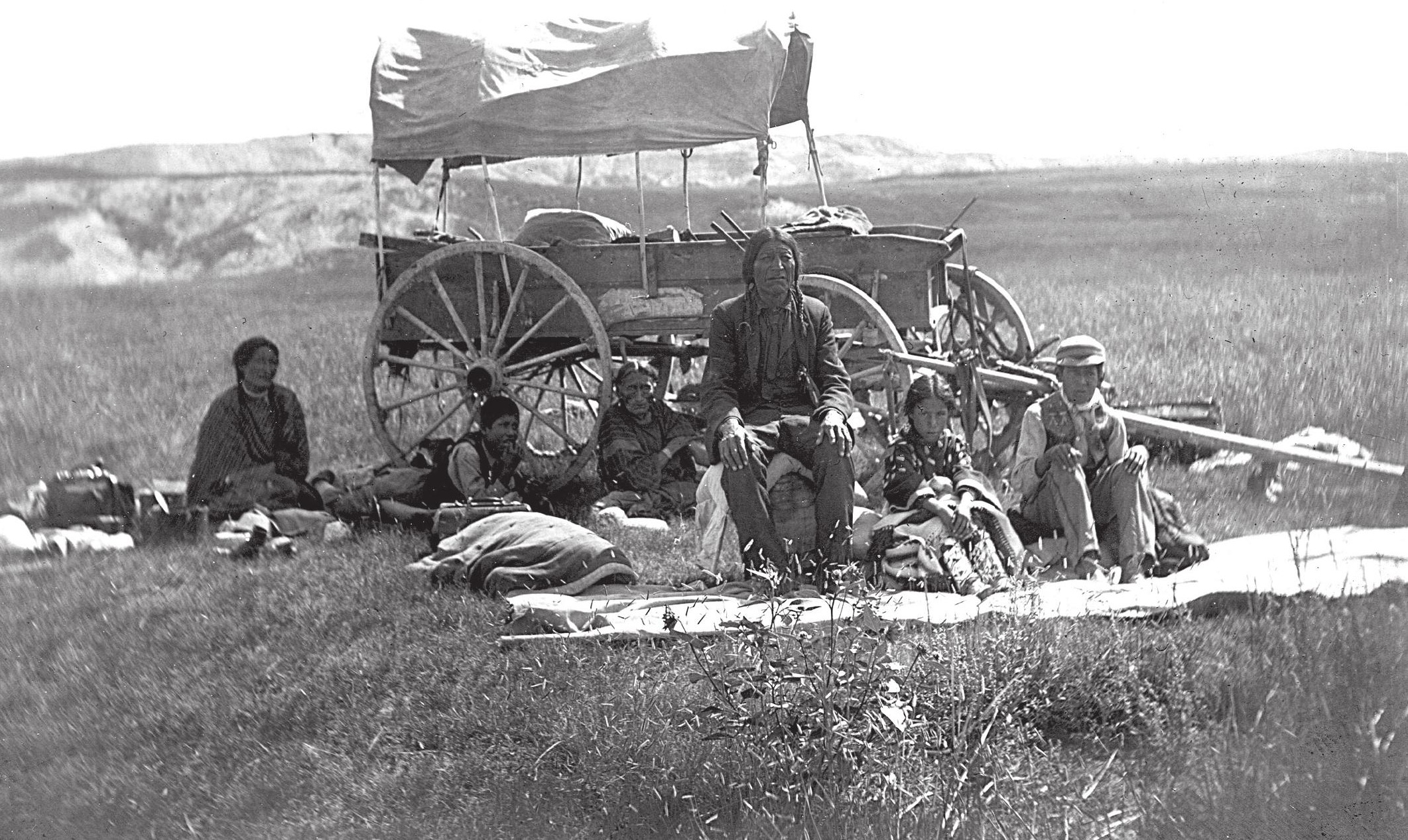




\section{Technical Assistance to Haskell Indian Nations University (Kansas)}

The USGS, through the Kansas Water Resources District Office, serves on the Haskell Indian Nations University's Natural Resources Advisory Board and advises Haskell on pertinent academic programs. In FY 2004, the USGS provided technical assistance and informal water quality sampling training to Haskell for their mobile water quality lab (purchased with U.S. Environmental Protection Agency grant funds). The lab will be used with nearby Tribes. Contact: Walt Aucott, 785-832-3505,waucott@usgs.gov

\section{Soil Conservation Outreach (Arizona, Colorado, New Mexico)}

Soil conservation is an important resource issue on lands of the Navajo Nation where soilstabilizing vegetation has been impacted by a combination of drought and grazing by domestic livestock. In October 2004, ecologists with the USGS Canyonlands Research Station met with a Navajo student at Northern Arizona University (NAU) in Flagstaff to discuss the student's observations of soil-erosion problems on the Navajo Nation. As a result of the meeting, the USGS scientists introduced the student to NAU faculty involved in resource-conservation work on the Navajo Nation and provided him with additional information concerning principles and methods of soil conservation. Contact: Jayne Belnap, 435-719-2333, Jayne_Belnap@usgs.gov or Mark Miller,435-719-2340,Mark_Miller@usgs.gov; Native American Contact: Delton Lester, dll8@ dana.ucc.nau.edu

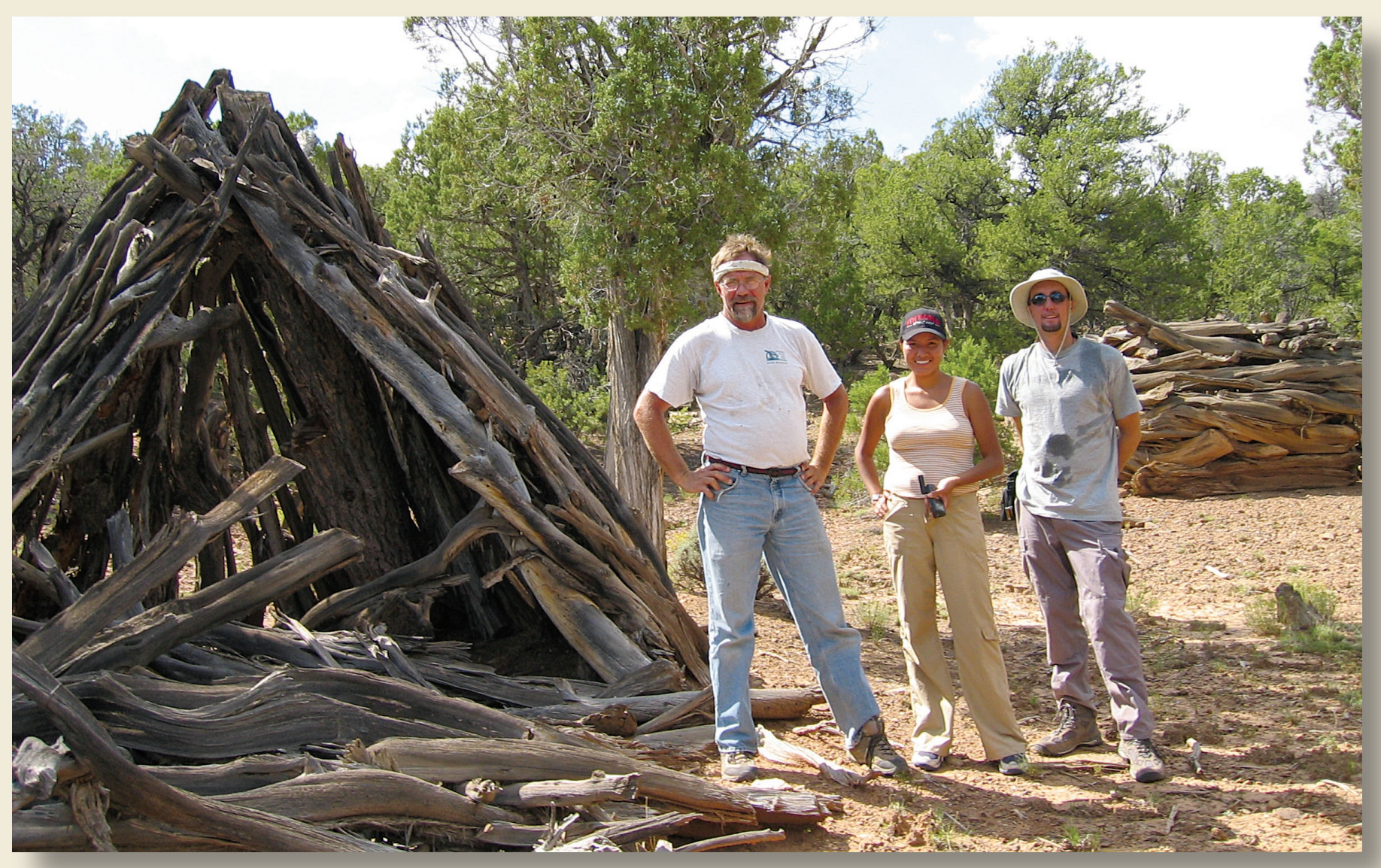

(Above) USGS volunteers working on vegetation mapping projects at Canyon de Chelly, New Mexico, on July 30, 2004 (from far left: Rob Hunt, Nasbah Ben, and Rob Klotz). The remnants of historic Navajo hogans are shown on the left. Photograph by Monica Hansen.

(Facing Page) Sioux Chief Wild Horse and family on the Pine Ridge Reservation, South Dakota, 1909. USGS Photographic Library; photograph by V.H. Barnett. 


\section{Explorer's Club-Outdoor Science Education Outreach on San Diego County Reservations (California)}

A retired USGS scientist has channeled her enthusiasm for earth science education into an outreach project for Indian Tribes in southern California. Working in partnership with the Tribes, the USGS, San Diego State University, and the San Diego Science Alliance, she has expanded a series of successful outdoor science activities originally developed under USGS auspices into a set of "Explorer's Club" programs for children whose ages range from 6 to 12 years. The format of each program is adapted to suit the needs of the Education Director or Recreation Director of each Tribe. Tribal elders are invited to participate as program instructors. The programs include activities such as panning for gold and magnetite, collecting rocks, coring soil, and learning outdoor photographic techniques. Water-related activities are particularly important to help the students understand water issues in their semi-arid area that has suffered six years of drought. Equipment from prior USGS funding is shared with children from the Campo Band of Kumeyaay Indians, Pauma Band of Luiseno Indians, Pala Band of Cupeno Indians, San Pasqual Band of Indians, Santa Ysabel Band of Diegueno Indians, Sycuan Band of the Kumeyaay Nation, and Viejas Band of Kumeyaay Indians. Contact: Eleanora I. (Norrie) Robbins,619-303-9095,norrierobbins@cox.net

\section{Anchorage, Alaska, ESIC Explains USGS Mapping to Alaska Native Students (Alaska)}

The Alaska Earth Science Information Center (ESIC) provided an opportunity for Native children from the Lower Kuskokwim School District to learn about various aspects of the USGS Geography Discipline during their annual June and July "Road Science" field trips. Among the topics covered were aerial photography, stereo imaging, and understanding map contours. Experiential learning techniques and activities got the students actively involved in learning to use special data. Approximately 80 students were involved in the program. Contact: Greg Durocher, 907-786-7009, gfdurocher@usgs.gov

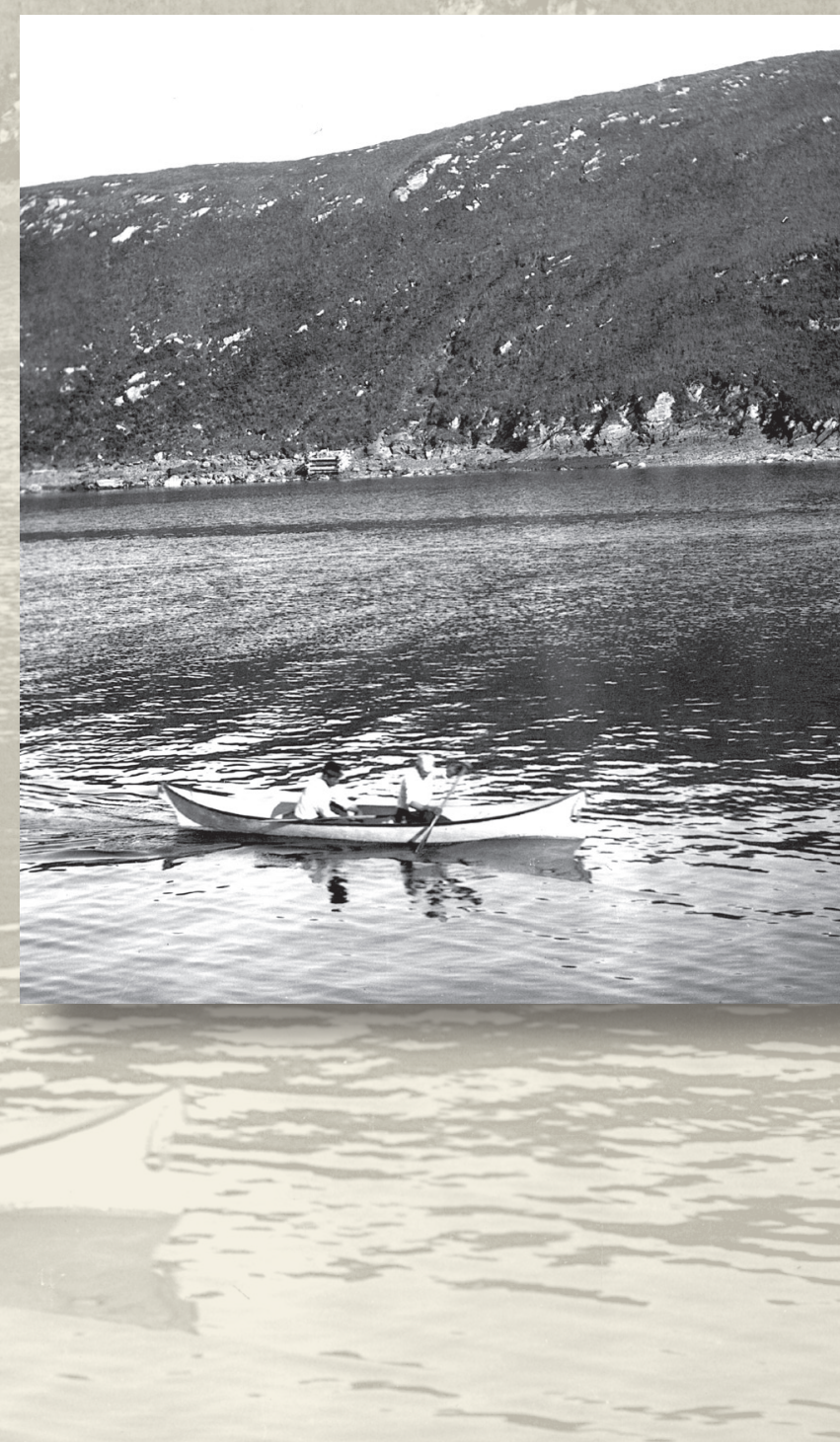




\section{Alaska Native Internship Program (Alaska)}

A USGS scientist continued a fisheries science internship program in the Bristol Bay region of Alaska during the summer of 2004. The focus of this 5-year program is to recruit Alaska Native students into the field of fisheries science through hands-on field experience. In 2004, over 10 students from Nondalton, Iliamna, Dillingham, and Kokanok, Alaska, learned what it was like to be a fisheries biologist. As part of a collaborative short-course with the National Park Service, students visited the USGS research site and learned how to estimate total salmon abundance, use a diverse array of scientific fishing gear, collect environmental data, enter data, and summarize and present their findings. Two students from previous years worked full time during the 2004 summer field season and assisted with all aspects of the research program, while another student continued to gain valuable work experience by serving as co-crewleader on a subsistence fishery sampling program. This experienced student acts as field crew leader on the otolith-sampling project. The other interns learned new skills such as aquatic habitat mapping, otolith collection, determining fish presence or absence in unsurveyed streams, preservation of samples for genetic analysis or aging, diverse fish capture methods, environmental monitoring techniques, and data entry and presentation techniques. The USGS coordinated the hands-on aspect of the internship program in partnership with the National Park Service at Lake Clark National Park and Preserve. This program has encouraged Alaska Natives to pursue college degrees and to consider careers in science. Contact: Carol Woody, 907-786-3512,carol_woody@usgs.gov

\section{Yupik Students Assist in Biological Research (Alaska)}

USGS scientists in Alaska are continuing to enhance communication between government researchers and Alaska Natives as they present career opportunities to Native youths. To demonstrate the kind of research being conducted, the USGS recruited 20 Yupik Eskimo students in 2004 to assist in a waterfowl study on the Yukon-Kuskokwim Delta in Alaska. The students experienced living at a remote site with biologists, and the students assisted the scientists in capturing geese and swans and fitting the birds with leg bands and neck collars. Movements of these waterfowl are being monitored as part of a large study to determine annual survival rates, migration pathways, and important staging and winter habitats. The year 2004 marks the 19th consecutive year of involvement by Alaska Native students from the Native village of Chevak in this important project. More than 180 Yupik youth have participated in this program since 1986. This effort supports a regional need for information on the population biology of species of interest to indigenous people, wildlife enthusiasts, and sport hunters. Contact: Craig Ely,907-786-3526,craig_ely@usgs.gov

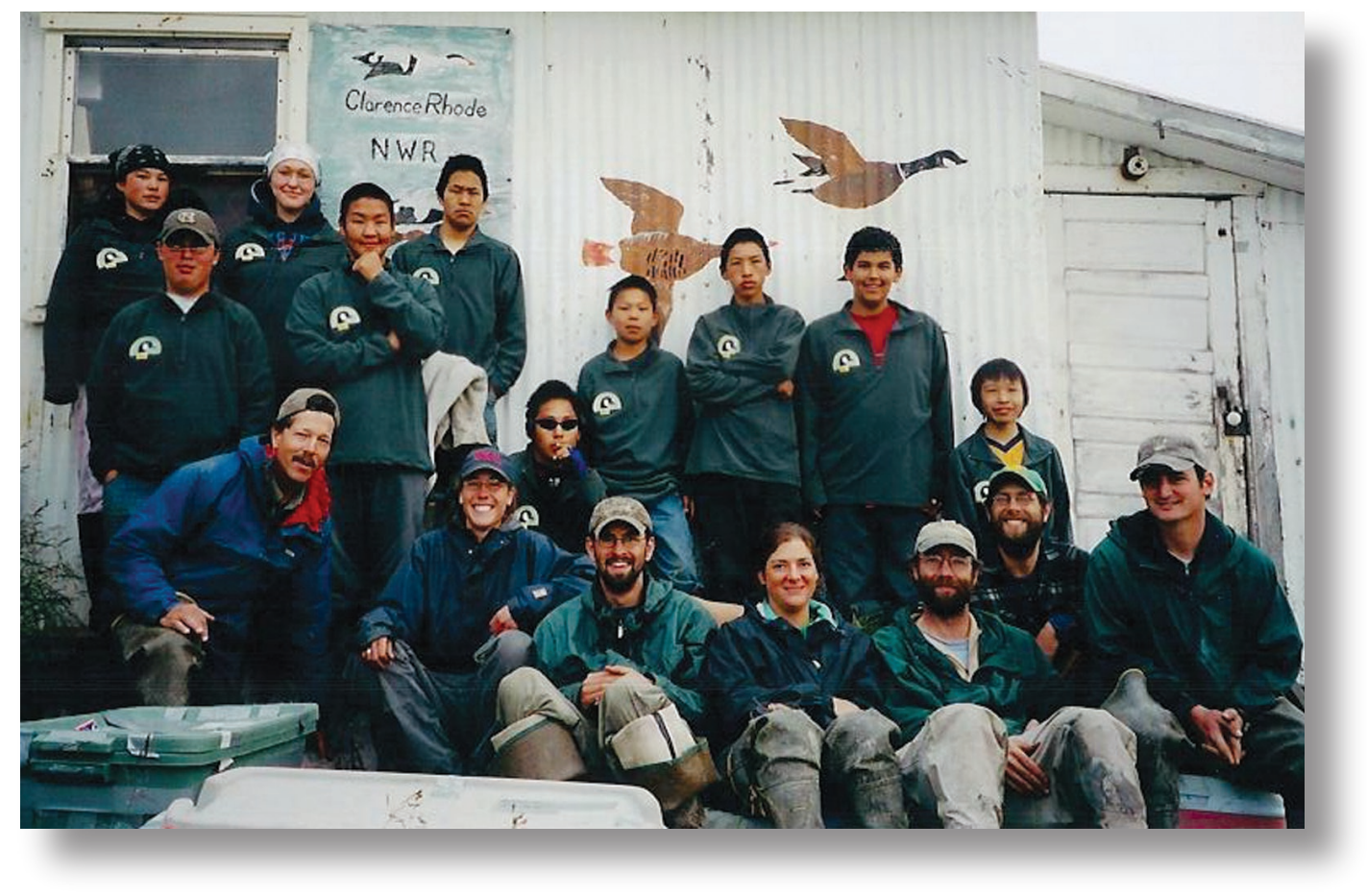




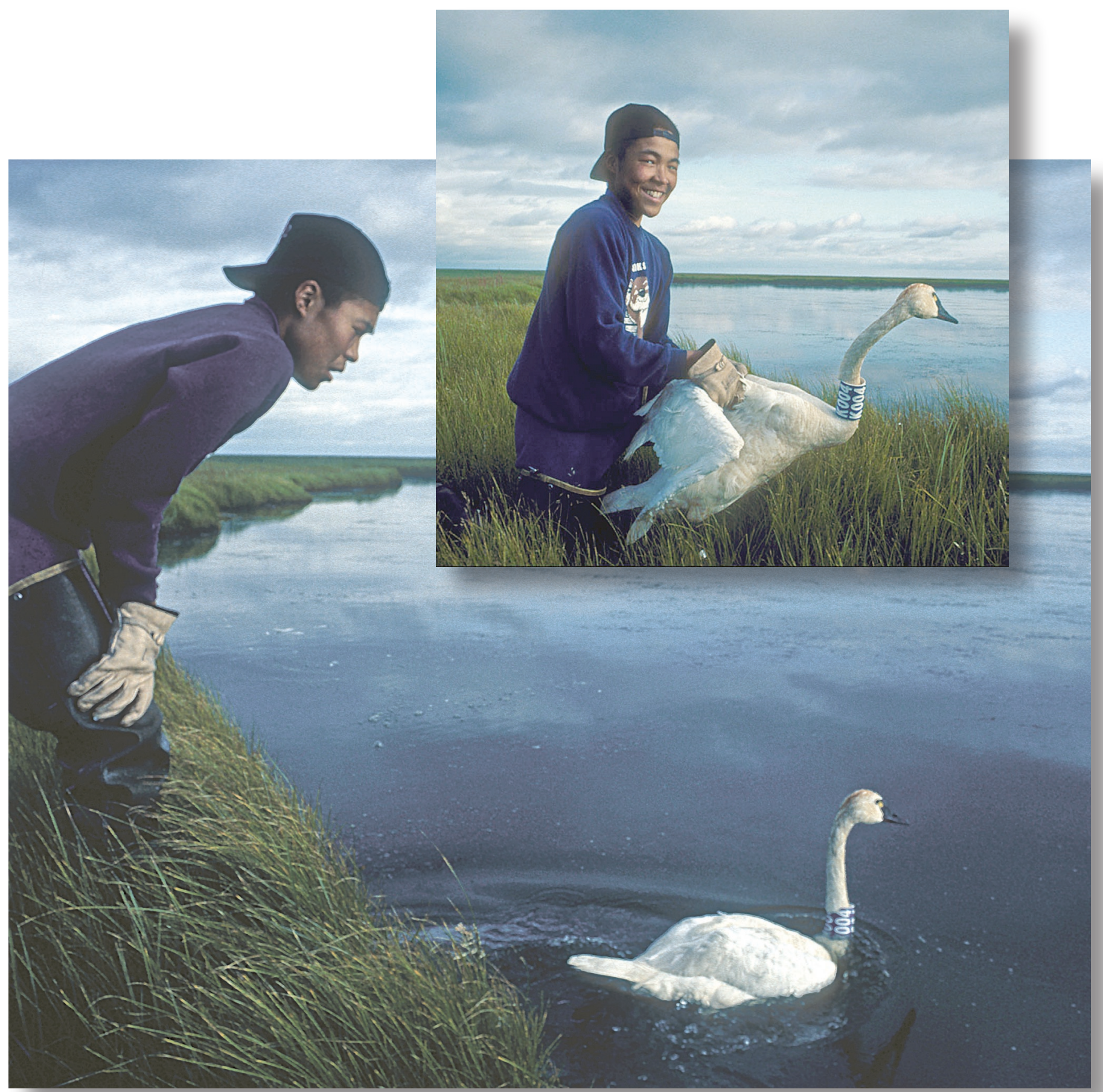

(Above) This Eskimo student is assisting USGS biologists in a waterfowl study on the YukonKuskokwim Delta in Alaska. He is holding a swan that has been fitted with a band and a collar. Photograph by Craig Ely, USGS.

(Left) Yupik students from Chevak, Alaska, helped band geese in the 19th year of this collaborative project. 








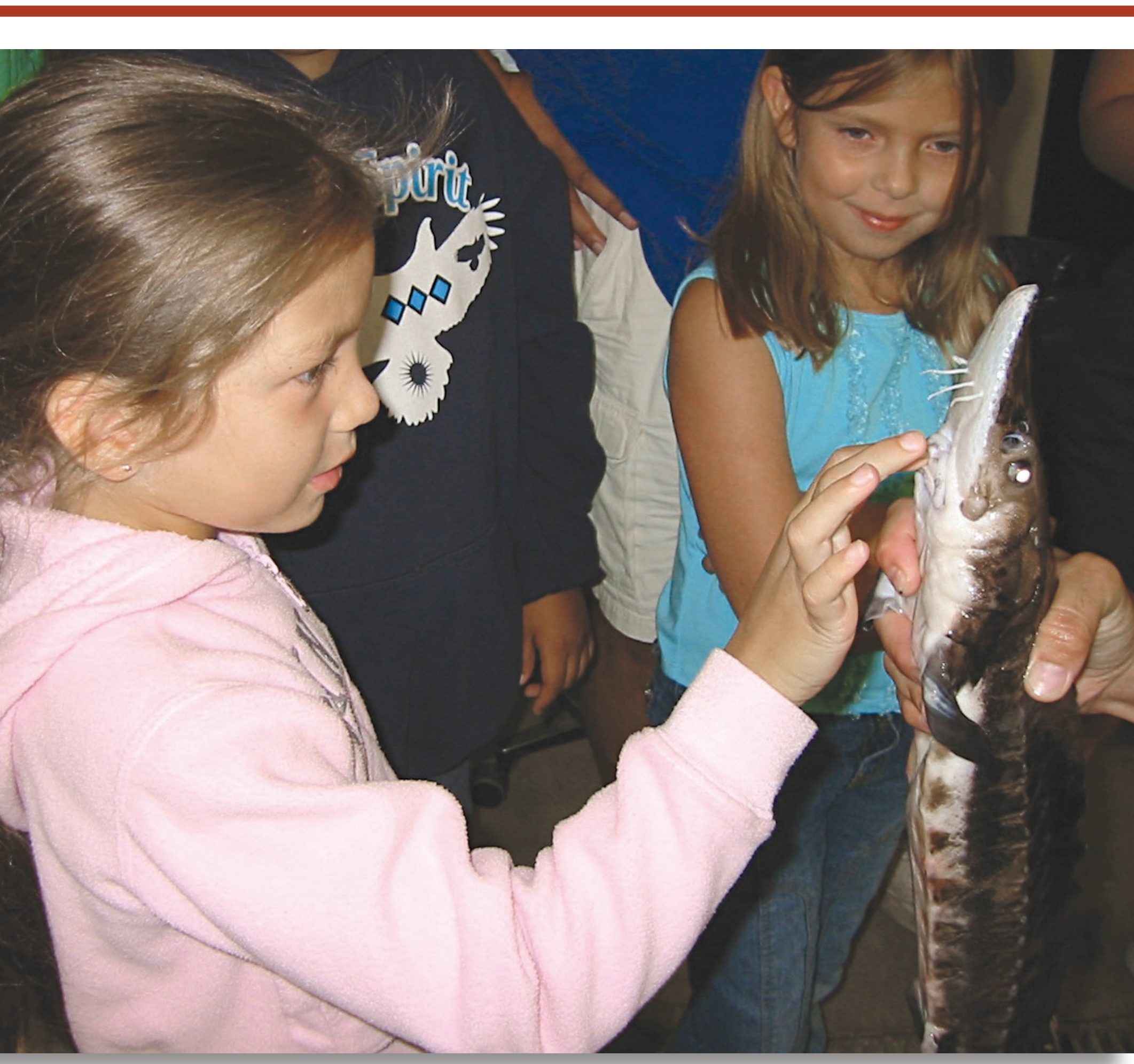

Ho-Chunk students learn about USGS sturgeon research. Photograph by Bob Kratt, USGS. 


\section{Nutrients, Organic Compounds, and Mercury in the Meduxnekeag River Adjacent to the Houlton Band of Maliseet Indians (Maine)}

While major point sources of nutrients in the Meduxnekeag River, Maine, have been reduced to levels permitted by the Maine Department of Environmental Protection, seasonal algal blooms in the river persist. One hypothesis is that seasonal algal blooms are driven by nutrients released from benthic sediments. Analyses of fish tissue samples in previous studies have indicated the presence of mercury, DDT, and other recalcitrant organic compounds. It is unclear whether these compounds are associated with stream-bottom sediments in the Meduxnekeag River. A USGS project was designed to establish the range of in-stream nutrient concentrations during the spring and summer of 2003 at sites upstream and downstream of Tribal lands. The study determined concentrations of nitrogen, phosphorous, mercury, and selected organic compounds in stream-bottom sediments at sites upstream and adjacent to the Maliseet lands. Additional project tasks included determining concentrations and ratios of carbon, nitrogen, and phosphorous in algal tissue collected from river samples at sites adjacent to tribal lands and assessing whether a relation exists between stream-water nutrients, sediments, and algal tissue. The project was completed and a report is being prepared. Contact: Charlie Culbertson,207-622-8201 ext.127, cculbert@usgs.gov

\section{Finding the Source of Fecal Coliform Bacteria in Water Used by the Houlton Band of Maliseet Indians (Maine)}

Contamination of water from human and animal waste is a major cause of deteriorating water quality in receiving waters and can have direct social and economic impacts to communities through the loss of sustenance and recreational activities. In recent years, fecal contamination of surface waters by nonpoint-source pollution (such as direct human and animal input, surface runoff, failing or inadequate septic systems, and sewer overflows or straight-pipes) has surpassed industrial and municipal point-source pollution. Mitigating this problem depends on knowing the ultimate source of the fecal contamination. Since many waterborne pathogens, including viruses, are extremely difficult to detect and quantify, information on the human or animal origin of the fecal pollution may give an indication of the types of pathogens that might be expected, the inherent risk of infection, and the subsequent treatment needed to control the transmission of disease. Recent developments in molecular biology and biochemistry have made it possible to use bacterial indicator organisms, such as fecal coliforms, to indicate the probable sources of pathogens. USGS scientists have begun a new study in cooperation with the Houlton Band of Maliseet Indians to identify the sources of fecal coliform bacteria in the Meduxnekeag River. The study is incorporating a deoxyribonucleic acid (DNA) fingerprinting technique (genotyping) to differentiate between human and non-human sources of coliform bacteria in water samples collected from the Meduxnekeag River, flowing through Maliseet Tribal land, near Houlton, Maine. The objectives of the research are to determine the occurrence, density distribution, and human or animal origin of fecal coliform bacteria from nonpoint-source pollution in a 6-mile stretch of the Meduxnekeag River, adjacent to and including the Houlton Band of Maliseet Indians Reservation. Contact: Charlie Culbertson, 207-622-8201 ext. 127, cculbert@usgs.gov 


\section{Support for Maliseet Water Quality Plan (Maine)}

The USGS Maine Water Resources District, in cooperation with the Houlton Band of Maliseets, Houlton Water Company, and Tate \& Lyle (formerly AE Staley Manufacturing Company) installed one new streamflow gage and restarted the historic streamflow gage on the Meduxnekeag River. The Meduxnekeag River Watershed is a Targeted Watershed under the U.S. Environmental Protection Agency's Targeted Watershed Program. These gages collect real-time streamflow information that is critical to ongoing USGS-Maliseet collaborations on water quality and quantity investigations, as well as addressing water-quality goals set-forth in the Targeted Watershed Program. Contact: Charles Culbertson, 207-622-8201 ext.127; cculbert@usgs.gov

\section{Aerial Infrared Remote-Sensing of Point- and Nonpoint-Source Discharge to the Meduxnekeag River (Maine)}

Point- and nonpoint-source inputs to rivers, lakes, and estuaries often occur via shallow water discharge zones and can contribute to elevated levels of organic and inorganic nutrients, algal blooms, low dissolved oxygen concentrations, and increased levels of bacterial contaminants, including fecal coliforms. Conventional methods of pollution source detection are time consuming and labor intensive, making effective surveillance of large geographic areas difficult and allowing many discharges to go undetected. We are using a remote-sensing technology, including aerial infrared imagery, to survey rivers and lakes. This technology can detect small temperature anomalies associated with aqueous inputs into receiving waters. Discharge zones identified by infrared imagery are GPS located and mapped for subsequent ground verification and sampling. Such a study is currently being conducted with the Houlton Band of Maliseets on Meduxnekeag River, Houlton, Maine. Contact: Charles Culbertson, 207-622-8201 ext.127; cculbert@usgs.gov

\section{Support for Passamaquoddy Water Management Plan (Maine)}

The USGS Maine Water Resources District is continuing to work with the Passamaquoddy Indians to collect real-time streamflow information critical to the development of a water management plan for Tribal land in southeastern Maine. The watershed includes important blueberry barrens and Atlantic salmon habitat. Careful stewardship of the land requires accurate streamflow information. The USGS is continuing to operate one stream gage to provide data for this work. Contact: Robert Lent,207-622-8201,rmlent@usgs.gov

\section{Ecological Health and Contamination in the Penobscot River (Maine)}

The Bureau of Indian Affairs (BIA), the USGS, the U.S. Environmental Protection Agency (EPA), the Agency for Toxic Substances and Disease Registry (ATSDR), and, initially, the University of Maine Analytical Environmental Chemistry Laboratory partnered to gather information regarding the occurrence, distribution, and ecological and human health risks associated with dioxins, furans, and PCBs in fish and sediment in the Penobscot River. A study was conducted to describe fish and sediment contaminant data from the Penobscot River's main channel from the Milford Dam impoundment in Old Town to Grindstone, Maine. The information produced was evaluated by the USGS, and a summary of the data quality was completed in 2003 . Due to the unreliability of the laboratory data, the data could not be used to determine the occurrence and distribution of these contaminants in the River. The USGS is continuing to work with the BIA, the lead agency, along with EPA and ATSDR, to propose a new study to assess human or ecological risks from potential contaminants in the river. A meeting was held at the Penobscot Indian Nation (Indian Island, Maine) in September 2003 to begin the proposal development process. Following that meeting a multi-agency proposal was developed. Contact: Carl Orazio, 573-876-1823,corazio@usgs.govor Susan Finger, 573-876-1850,sfinger@usgs.gov 


\section{Salmon Migration and the Penobscot Indian Nation (Maine)}

The USGS Conte Anadromous Fish Lab is participating in an adult Atlantic salmon migration project on the Penobscot River in cooperation with the Penobscot Indian Nation (PIN) and the Maine Atlantic Salmon Commission. The PIN has treaty-reserved sustenance fishing rights in a large part of the watershed. Thus, the PIN has great interest in the ongoing efforts to restore Atlantic salmon to the Penobscot River, including improving understanding of the current migration success of adult salmon through the multiple fish ladder system. This project was driven by a document produced by the Maine Atlantic Salmon Commission's Technical Advisory Committee and reflects the PIN's input to that document. The USGS role in this project has become more advisory while the Salmon Commission scientists analyze the data. The Penobscot's concerns about the passage rates, behavior, and performance of other migratory species, such as alewives, American shad, and American eels, will be considered as part of planning the future direction of this project. Contact: Alex Haro (USGS), 413-863-3806, Alex_Haro@usgs.govor Clem Fay (Penobscot Indian Nation), 207-827-7776,pinfish@penobscotnation.org

\section{Ground Water and the Tuscarora Nation (New York)}

The USGS assisted the Tuscarora Nation in assessing consultant reports dealing with ground-water conditions in the Lockport Dolomite bedrock on Nation lands. The New York Power Authority (NYPA) is renewing their Federal Energy Regulatory Commission (FERC) license for operations at the Robert Moses Hydropower Plants. The NYPA pump-storage reservoir is partially sited on the Tuscarora Nation and impacts local ground-water conditions. The assessment of this reservoir and other facilities of the Robert Moses complex indicated that while the reservoir does recharge local ground-water, the recharged water is drawn from the Niagara River. At least one source of contamination by the residual chemicals benzene, toulene, and xylene from the breakdown of petroleum was discovered on the Tuscarora Nation during this investigation though it was not related to NYPA activities. The Nation intends to build a public water supply system and will use a consultant's report to assess how to best achieve water supply development. The consultant's work was based on a regional model of ground-water flow developed by the USGS about a decade ago and on several other USGS reports developed for the Niagara Falls area. Contact: Bill Kappel, 607-266-0217 ext. 3013, wkappel@usgs.gov

\section{Tribal Fisheries Restoration and Enhancement in the St. Lawrence River Tributaries (New York)}

Scientists from the Great Lakes Science Center's Tunison Laboratory of Aquatic Science, in Cortland, New York, continued assisting Tribes in restoring and enhancing their fisheries. Tunison scientists continued assisting the St. Regis Mohawk Tribe by examining the feasibility of restoring Atlantic salmon in St. Lawrence River tributaries. Salmon restoration activities included stocking 25,000 salmon fry in tributaries of the St. Regis and Little Salmon Rivers and assessing survival through the fall. Survival of salmon fry in Hopkinton Brook, a tributary of the St. Regis River, was higher in 2004 than in previous years whereas survival in the Little Salmon River was similar to earlier years. Yearling Atlantic salmon were captured at each site, indicating over-winter survival. Contact: James H. Johnson, 607-753-9391 ext. 30, james_h_ johnson@usgs.gov 


\section{Sturgeon Enhancement in the Great Lakes (New York)}

Scientists of the Great Lakes Science Center's Tunison Laboratory of Aquatic Science, in Cortland, New York, and representatives of the Environment Division of the St. Regis Mohawk Tribe are conducting a comprehensive assessment of the presence, river distribution, habitat use, and size distribution of juvenile lake sturgeon stocked into the lower St. Regis River in 1998-2004. In this first season of the assessment, 67 sturgeon, representing all years in which the sturgeon were stocked, were captured throughout the target $32 \mathrm{~km}$ river section. Environmental quality characteristics were measured for the application of habitat suitability models. This research focuses on assessing an ongoing sturgeon restoration program in this tributary of the St. Lawrence River, but the results will be applicable to many historic sturgeon waters throughout the Great Lakes and will provide information and an assessment of techniques needed for the enhancement of this threatened native species in its historic habitat. Contact: Dawn E. Dittman, 607-753-9391 ext.23,ddittman@usgs.gov

\section{Aquatic Species and Habitat of the Akwesasne Marsh (New York)}

The St. Regis Mohawk Tribe, the Mohawk Council of Akwesasne, and scientists at the USGS Great Lakes Science Center Tunison Laboratory of Aquatic Science are conducting a study to provide a quantitative assessment of the ecological health of the Akwesasne Marsh system in relation to the hydrologic regime. Operation of the Moses-Saunders Dam and the associated alteration of the hydrologic regime, both upstream and downstream of the dam, are among the factors that may be degrading the marsh. The sampling design was developed in consultation with Canadian and U.S. Mohawk environmental experts. Field collections provided the necessary baseline data on fish assemblages and associated abiotic conditions, including hydrologic status (for example, water level). Field sampling was cooperatively performed by USGS scientists and technicians and St. Regis Mohawk Tribe Environmental Division wetland biologists and technicians. These data will provide information critical to effective management of the hydrologic regime in this large aquaticwetland system and will assist in potentially restoring the natural community of the Akwesasne Marsh. It will also contribute to model development by the International Joint Commission's Environmental Technical Work Group Integration Sub-group that may indicate the characteristics that would maintain optimal biotic conditions in the St. Lawrence River in general, and more specifically for the Akwesasne Marsh. Contact: James E. McKenna, Jr., 607-753-9391, jemckenna@usgs.gov

\section{Seneca Nation of Indians Water Supply Aquifer (New York)}

In FY 2003, the USGS New York Water Science Center signed a Cooperative Water Agreement with the Seneca Nation of Indians. The Seneca Nation is working with USGS hydrologists to locate an aquifer that will supply potable water for domestic uses. The USGS will assess the hydrogeology of an aquifer system that the Seneca Nation hopes to use as a new water supply. Initially, the Seneca Nation intended to drill a single water-supply well in a confined aquifer. The USGS seismic-refraction surveys identified a confined aquifer in that location that may have produced unacceptably high concentrations of barium. The Seneca Nation then refocused its efforts to find a new location for multiple wells in an unconfined sand and gravel aquifer that would provide better quality water. Without the USGS seismic information, drilling in the original planned location would have located unusable water. Data from additional seismic work at a different location indicated the presence of an unconfined aquifer. Test drilling, drawdown analyses, and water-quality sampling of the test wells drilled in this new area by the USGS indicated an acceptable aquifer, which could supply good quality water at an acceptable rate for the Seneca Nation's future water supply. The four test wells were sampled for basic cations and anions, nutrients, trace metals, and pesticides to ensure that the quality of the water in the unconfined aquifer is acceptable for future development by the Seneca Nation. The ground-water study is continuing. It will include developing a ground-water-flow model of the aquifer system. Information on the sources of recharge to the aquifer and estimates of pumping capacity will help the Seneca Nation better manage the ground-water resources for its citizens. Contact: Ed Bugliosi, 607-266-0217 ext.3005, ebuglios@usgs.gov 


\section{South Florida Ecosystem Program, Internal Surface Water Flows}

As part of the Everglades Restoration Programs, the U.S. Army Corps of Engineers and South Florida Water Management District propose modified water deliveries to The Seminole Tribe of Florida, Big Cypress National Preserve, and other parts of Florida's interior. The proposal is intended to provide net flood protection and water delivery to agricultural lands as well as partial restoration of historic ecosystem conditions within the Seminole lands. A baseline of current data is needed to help determine the effects that proposed water delivery changes will have on Seminole lands. The USGS has installed and is obtaining data from strategically located streamflow gaging sites to help define future surface-water flow requirements and decompartmentalization efforts through the Comprehensive Everglades Restoration Program. Subsequent studies based on accurate flow calibrations generated by data from these sites may then be used by other agencies for computation of nutrient and other contaminant loadings in the canal system. Data from continuous flow gages, at selected impact points for interior basins, will also complement the existing eastern flow canal discharge network and allow more accurately timed surface-water releases. USGS biologists are using the hydrological restoration of a wetland that had been drained for cattle pasture to test several hypotheses about the invasion of wetlands by non-native species, including methods that may discourage non-native species from invading such wetlands. Contact: Mitch Murray (USGS, water), 305-717-5827, mmurray@usgs.govor Bill Loftus (USGS,biology),305-242-7835Loftus@usgs.gov or Craig Tepper (Seminole Tribe of Florida),954-966-6300,ext.1120,water@gate.net

\section{Mapping Bottom Substrates in the Lower Bad River and Adjacent Areas of Lake Superior (Wisconsin)}

The USGS Great Lakes Science Center's Lake Superior Biological Station developed an agreement with the Bad River Band of Lake Superior Tribe of Chippewa Indians to conduct a benthic mapping survey of the lower 2 miles of the Bad River and adjacent 4 miles of lakeshore habitat in Lake Superior. Detailed data on the distribution of depths and bottom substrate composition were collected in GIS (Geographic Information System) mapping format during 2004, and will be used after project completion by the Bad River Band to assist in describing lower stream reach staging habitats for lake sturgeon. The U.S. Fish and Wildlife Service (USFWS) Ashland Fishery Resources Office is partnering with the USGS to carry out this project for the Bad River Band. Lake sturgeon have been designated as a species of concern by the USFWS. Understanding the relationship among habitat, lake sturgeon spawning, and survival of young lake sturgeon will provide Tribal natural resource managers information to protect these areas to enhance recovery of Lake Superior lake sturgeon populations. A final report co-authored by the USGS, USFWS, and the Bad River Band has been published (G. Cholwek, D. Yule, M. Eitrem, H. Quinlan, and T. Doolittle, 2005, Mapping potential lake sturgeon habitat in the lower Bad River complex: Ann Arbor, MI, Great Lakes Science Center, Technical Report). Contact: Dan Yule (USGS) 715-682-6163, dyule@usgs.gov or Mark Dryer (USFWS) 715-682-6185, mark_dryer@fws.govor Tom Doolittle 715-682-7111 (Bad River Band),wildlife@badriver.com 


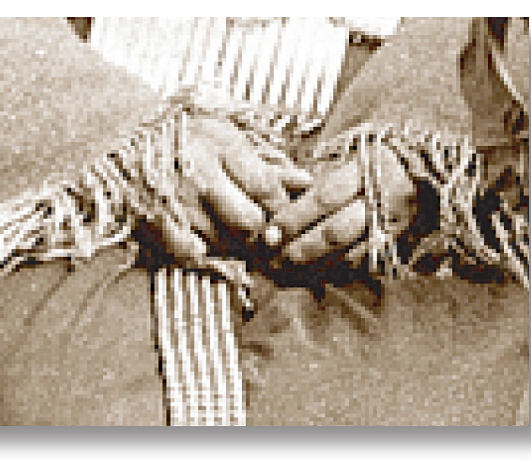

\section{Bad River, Wisconsin, Streamflow, Sedimentation, and Erosion Study}

The major objective of this study is to understand how streamflow, erosion, and sedimentation rates have changed in the Bad River and some of its key tributaries over time due to changes in land cover. The study began in FY 2002 in cooperation with the Bad River Band of Lake Superior Chippewa Indians. Historical aerial photographs and government land office survey maps were used to identify reaches with bluff or bank erosion, lateral migration, and bar formation. Partial valley cross sections were surveyed at seven locations along the Bad River and Marengo River, and 70 cores were collected and described from flood-plain, channel, and abandoned channel environments. In FY 2004, cores were collected and surveying was done at a site on the Marengo River and a site near the ancestral channel of the Bad River at the head of the Kakagon River. The core data, combined with elevation data from the valley surveys, are being used to determine relative differences between pre- and post-European settlement erosion and sedimentation rates. A USGS report is being prepared. Contact: Faith Fitzpatrick (USGS), 608-821-3818,fafitzpa@usgs.gov or Kirsten Cahow (Bad River Band), 715-682-7123,water@ badriver.com

\section{Freshwater Mussel Assistance to Bad River Band (Wisconsin)}

The Sea Lamprey Control Program of the U.S. Fish and Wildlife Service annually monitors sea lamprey populations and chemically treats tributaries on Tribal and non-Tribal lands throughout the Great Lakes basin to eradicate larval sea lamprey. The Bad River Band of the Lake Superior Chippewa Indians requested information on the effects of these pesticides on mussels in the White River, which flows through their lands. The USGS conducted cooperative assessment studies with Tribal staff to look at short- and long-term effects of lampricide treatments on two species of mussel in order to guide future management actions. The following scientific publication resulted: D.L. Waller, T.D. Bills, M.A. Boogaard, D.A. Johnson, and T.C.J. Doolittle, 2003, Effects of lampricide exposure on the survival, growth, and behavior of the unionid mussels Elliptio complanata and Pyganodon cataracta: Journal of Great Lakes Research 29, Supplement 1, p. 542-551. Contact: Mike Boogaard, 608-781-6238, mboogaard@usgs.gov

\section{Lake Sturgeon Enhancement in Menominee Waters Continues (Wisconsin)}

The Menominee Reservation Lake Sturgeon Enhancement Committee, composed of personnel from the Menominee Indian Tribe of Wisconsin, U.S. Fish and Wildlife Service, Wisconsin Department of Natural Resources, and the USGS, is coordinating ongoing efforts to re-establish lake sturgeon in waters on the Menominee Reservation. One of these efforts involves evaluating success of stocking juvenile and fingerling lake sturgeon in Reservation impoundments. The USGS fishery biologists at the Upper Midwest Environmental Sciences Center continue to provide assistance to Menominee employees in the monitoring of transmitters in adult lake sturgeon on the Wolf River near Keshena, Wisconsin. These efforts will help resource managers determine habitat requirements of stocked lake sturgeon in Reservation impoundments. Contact: Steve Zigler,608-781-6395, szigler@usgs.gov

(Facing Page) Historical image courtesy of the Blue Cloud Abbey at Marvin, South Dakota. 


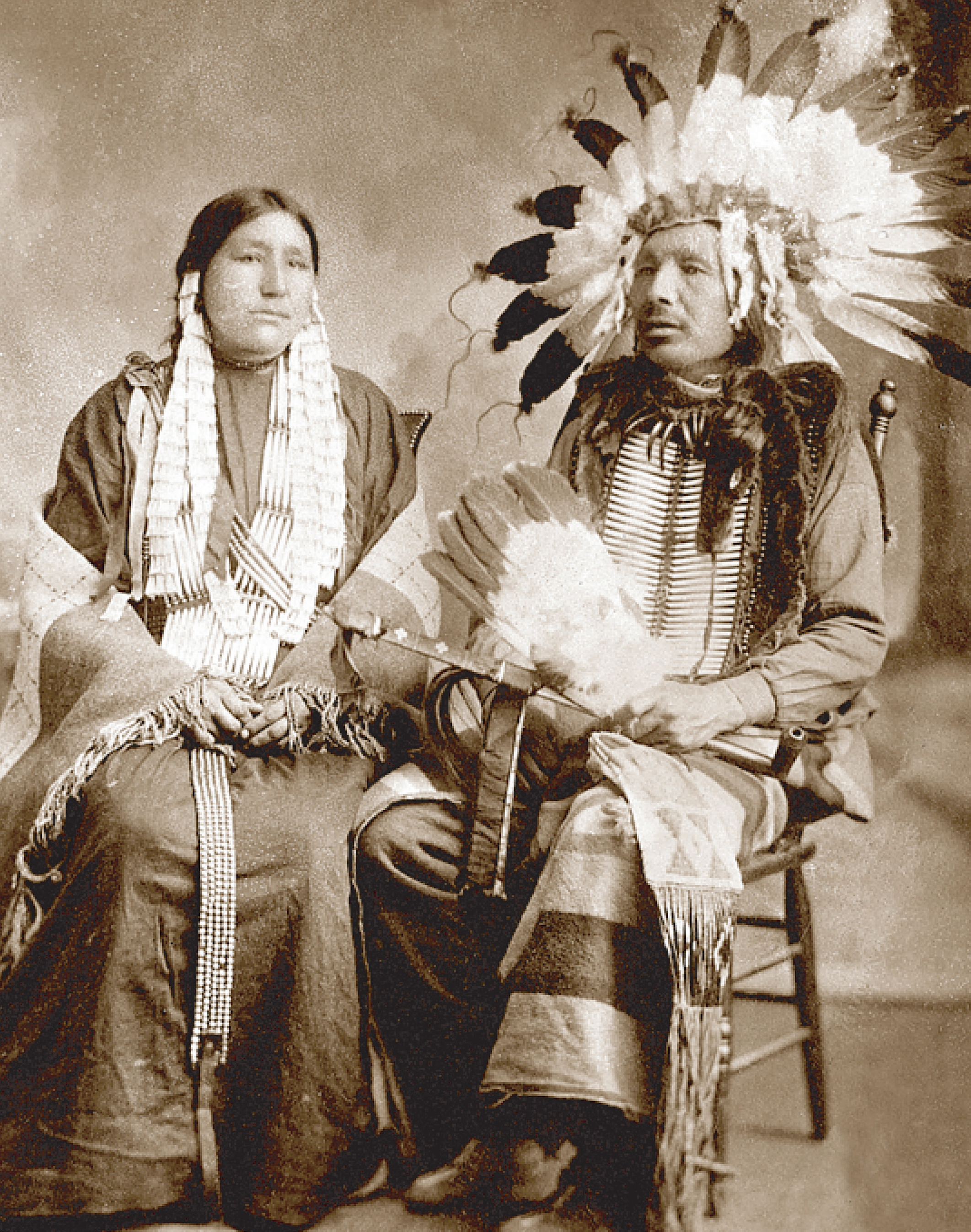




\section{Ground-Water Flow Studies with the Stockbridge-Munsee Indian Tribe of Wisconsin}

The Stockbridge-Munsee Indian Tribe of Wisconsin is interested in improving their understanding of the regional hydrogeology and shallow ground-water flow on their lands. The Tribe is specifically interested in shallow ground-water flow in the Red Springs area, where farm land will be developed for residential neighborhoods over the next several years. The Tribe is concerned that past farming practices may adversely affect water quality in private wells. To assist the Stockbridge-Munsee Tribe, the USGS constructed a single-layer analytic element (AE) ground-water flow model, the near-field of which covers all of the Stockbridge-Munsee Reservation. The calibrated AE ground-water model was used to characterize regional ground-water flow across the Reservation and also simulates ground-water flow paths at specific locations of interest in the Red Springs area. The AE ground-water-flow model has also been used to assist the Tribe in choosing a site for a new municipal well for Tribal properties along County Road A, including a health center and a casino. Model simulations were used to identify locations that would provide sufficient water supplies and whose recharge areas were within undeveloped Tribal lands. The flow model is currently being used to simulate the effect on the local water table of infiltrating return flow from the municipal system. A USGS Water Resources Investigation Report entitled, "Simulation of Shallow Ground-Water Flow on the Stockbridge-Munsee Indian Reservation, Wisconsin, Using Analytic Element Modeling" is being prepared. Contact: Charles Dunning (USGS), 608-821-3827, cdunning@usgs.gov or Greg Bunker (StockbridgeMunsee Indian Tribe of Wisconsin), 715-793-5118, gbunker@frontiernet.net

\section{Ho-Chunk Water Quality (Wisconsin)}

The USGS Wisconsin Water Science Center is assisting the Ho-Chunk Nation by assessing the hydrology and water quality of the streams on, and in close proximity to, Ho-Chunk lands. A Water Resource Investigations report entitled, "Surface-Water-Resource Information for the Ho-Chunk Nation Lands and Vicinity, Wisconsin," by M.W. Diebel and D.J. Sullivan, was published in 2003 (USGS Water Resources Investigation Report 02-4307). The report included an analysis of existing information on chemical, physical, and biological investigations. Additional water-quality and biologic data were collected in 2003 at Ho-Chunk Nation sites. A pesticide reconnaissance study was conducted during spring 2004. During the summer and fall of 2004, fish and benthic invertebrate samples were collected at several sites in the Kickapoo River area, Vernon County, Wisconsin. Contact: Judith Coffman Thomas USGS), 608-8213814, juthomas@usgs.govor Randy Poelma (Ho-Chunk Nation), 800-944-1652, Rpoelma@ ho-chunk.com

Ho-Chunk students learn to hold a corn snake at the USGS Upper Midwest Environmental Sciences Center. Photograph by Bob Kratt, USGS.

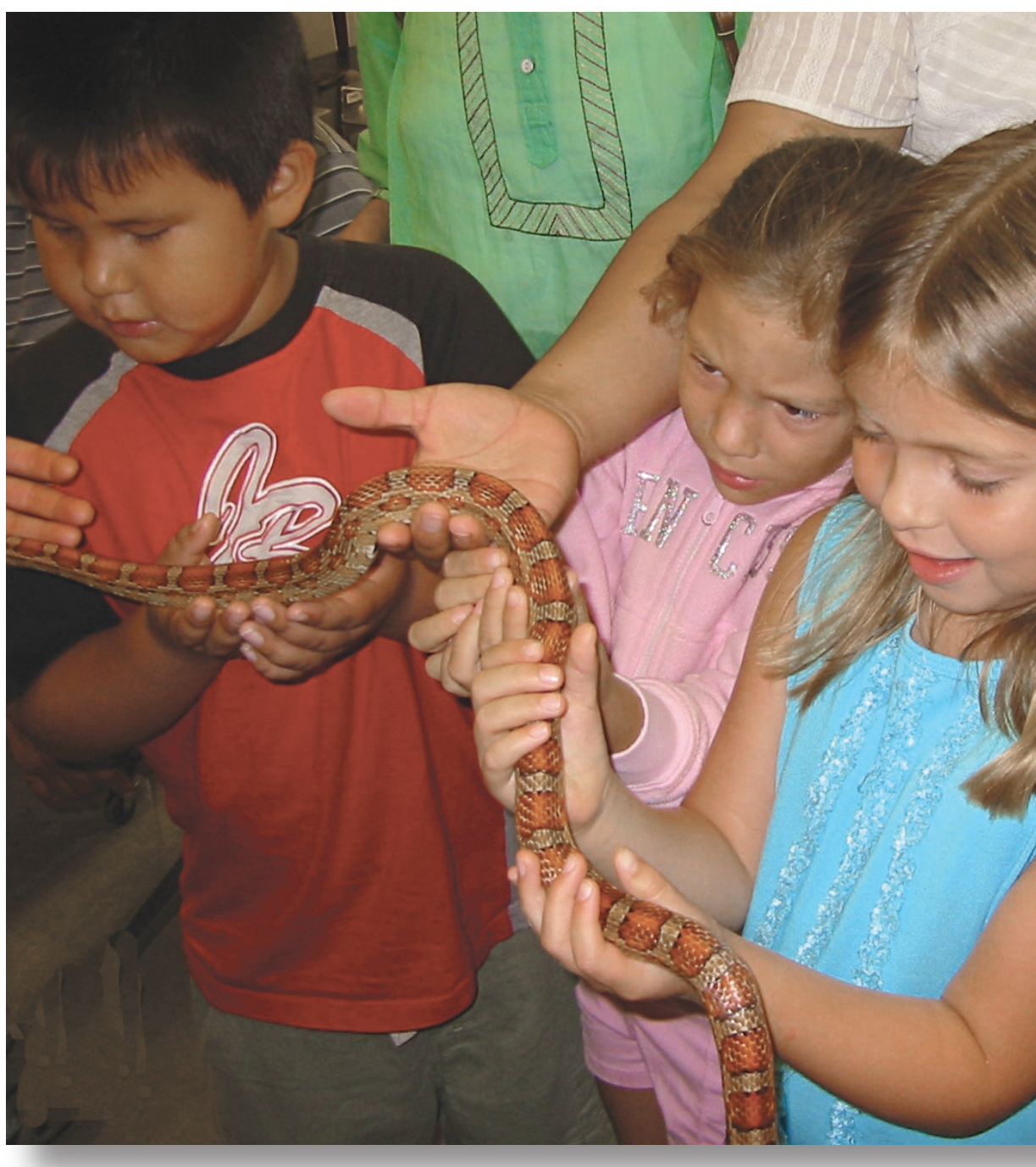




\section{Water-Level Management Assistance to Rainy River First Nations, Canada}

USGS biologists and geographers participated in a meeting of the Rainy Lake and Namakan Reservoir Water Level Monitoring Committee at Voyageurs National Park, International Falls, Minnesota, in January 2004. One USGS scientist has provided consultation to this group since 2000 and has been invited to participate in data analysis, integrative modeling, and publication of study results. Another USGS scientist presented a demonstration of decision support systems to the Committee. A third USGS scientist discussed the use of IKONOS multispectral satellite data in the water-level studies. Stakeholders in the water-level studies include the U.S. National Park Service, Minnesota Department of Natural Resources, Ontario Ministry of Natural Resources, Rainy River First Nations (Anishinaabe and Ojibwa peoples), and the Boise Cascade and Abitibi Consolidated paper companies. Contact: Steve Gutreuter, 608-7816222,sgutreuter@usgs.gov

\section{Delineating Critical Habitat for Young Lake Sturgeon in the Lower St. Louis and Pigeon Rivers (Minnesota)}

The USGS Great Lakes Science Center's Lake Superior Biological Station is supporting a cooperative project of the Grand Portage Band of Chippewa, the Fond du Lac Band of Chippewa, the 1854 Authority, and the U.S. Fish and Wildlife Service (USFWS). The Grand Portage Band of Chippewa recently received a USFWS Tribal Wildlife Grant to apply telemetry equipment to identify and delineate critical juvenile and sub-adult lake sturgeon habitat on a seasonal basis in the St. Louis and Pigeon Rivers, Minnesota. This work will augment existing evaluations of lake sturgeon rehabilitation programs within the 1854 Ceded Territory boundaries. The Lake Superior Biological Station is providing lake sturgeon length and seasonal distribution data and base habitat maps from their 15-year-monitoring program on the St. Louis River to help locate potential concentrations of young lake sturgeon for tagging purposes. Contact: Jason Stockwell (USGS) 715-682-6163, jstockwell@usgs.gov or Mark Dryer (USFWS) 715-682-6185, mark_dryer@fws.gov or Andy Edwards 218-722-8907 (1854 Authority), aedwards@1854authority.org

\section{Ground Water and Water Quality of Lakes and Springs on Lands of the Grand Portage Band of Lake Superior Chippewa (Minnesota)}

The USGS Minnesota Water District Office is delineating the direction of ground-water flow and sources of recharge water to lakes and wetlands on lands of the Grand Portage Band of Lake Superior Chippewa. The Grand Portage Band will use the information to help them evaluate potential land use in environmentally sensitive ground-water recharge areas. The study will also provide information regarding Tribal water resources. Contact: Don Hansen, 763-7833250,dshansen@usgs.gov 


\section{Moose Population Dynamics in Northeastern Minnesota}

The USGS Minnesota Field Station of the Northern Prairie Wildlife Research Center is conducting moose research with the Minnesota Department of Natural Resources, Fond du Lac Band of Lake Superior Chippewa, and the 1854 Authority (Grand Portage and Bois Forte bands of NE Minnesota Chippewa). The objectives of the study are to determine survival rates of adult moose, causes of mortality, and to improve aerial surveying of the moose population. In February 2004 (year three of the five-year study) 18 adult moose (12 females, 6 males) were captured and radio-collared, increasing the total number of radioed moose to 84 animals. These were radio-tracked aerially once per week, accumulating approximately 1,000 locations. From February through December 2004, 9 of 60 (15\%) have died, 2 from natural causes and 7 from human causes. Of the 84 total moose studied to date, 34 have died and 32 of those have been examined. The causes of death are: 15 unknown natural causes (not predation), 8 legally shot, 2 illegally shot, 1 train-kill, 2 road-kills, and 1 natural accident. This information will help the Tribes and the State improve moose management by providing information critical to the longterm welfare of moose in Minnesota. Thirty additional moose will be captured in FY 2005 to add to and replace the study animals that have died. They will be the last moose captured for this study. Contact: Michael Nelson,218-365-4505,_michael_nelson@usgs.gov

\section{Hydrologic and Lake-Level Changes, Long Lost Lake, White Earth Band of the Minnesota Chippewa Tribe (Minnesota)}

Long Lost Lake is a 480-acre landlocked lake within the boundaries of the White Earth Indian Reservation. The lake is approximately 6 miles west of Lake Itasca, the source of the Mississippi River, in northwestern Minnesota. The water level (stage) of Long Lost Lake has risen approximately 20 feet since about 1990. Twelve Tribal residences, several roads, and 50 acres of Tribal lands are submerged, and 30 Tribal members have been displaced from their homes. The USGS Minnesota Water Resources District is working with the Tribe to document historical changes in the stage of Long Lost Lake to determine the cause-and-effect relationships that have resulted in increased lake stage, and to develop a general understanding of the hydrology of lakes that experience rapid and dramatic changes in lake stage. Climatological changes and human modifications within the watershed were considered as potential contributing factors. Above-normal precipitation within the watershed during the late 1990's was the major factor contributing to the lake-level change. Project personnel also developed and implemented a monitoring network that was needed to understand the hydrologic setting and hydrologic budget of Long Lost Lake and to provide information about the lake's setting relative to other lakes in the area. The monitoring is continuing. The study began in FY 2002 and is expected to conclude in FY 2005. Contact: Don Hansen, 763-783-3250, dshansen@usgs.gov

\section{Ground-Water Resource Assessment for the Upper Sioux Community near Granite Falls (Minnesota)}

The USGS Minnesota Water District Office and the Upper Sioux Community environmental office are determining the availability of ground water to meet increased water supply needs for planned residential, commercial, retail, and tourist development for the Upper Sioux Community. Ten test holes and three observation wells were installed and real-time ground-water monitoring of municipal and observation wells is planned. Contact: Don Hansen, 763-7833250,dshansen@usgs.gov 


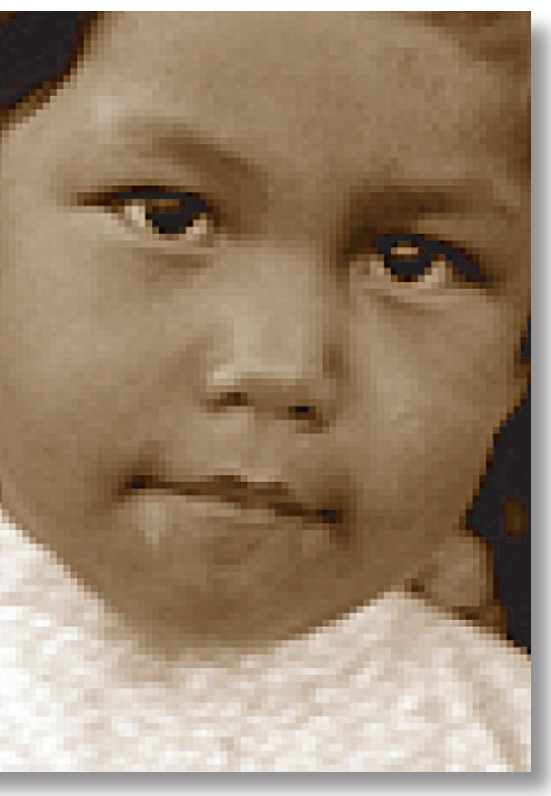

\section{Water Availability for the Franconia-Ironton-Galesville Aquifer, Shakopee Mdewakanton Sioux Community (Minnesota)}

Employees of the Shakopee Mdewakanton (Dakota) Sioux Community and the USGS Minnesota Water District Office conducted an aquifer test to determine the potential water availability from the Franconia-Ironton-Galesville aquifer. The Community is located in the southwest Minneapolis-St. Paul metropolitan area. The population of this area is growing rapidly and ground-water resources are in high demand. Results of the test will determine the source of water to the pumping well and the effects of additional withdrawals on nearby observation wells. Contact: Don Hansen, 763-783-3250,dshansen@usgs.gov

\section{The Prairie Island Indian Community and Sturgeon Lake (Minnesota)}

Employees of the Prairie Island Indian Community and the USGS Minnesota Water District Office conducted a bathymetric survey of Sturgeon Lake and collected bottom sediment samples from the lake. The Community is concerned about potential water-quality effects of dredging of the lake for pleasure boat traffic. Contact: Don Hansen, 763-783-3250,dshansen@usgs.gov

\section{Water-Quality Monitoring with the Yankton Sioux Tribe (South Dakota)}

The Missouri River in southeastern South Dakota constitutes the southern boundary of the Yankton Sioux Reservation (YSR) and is a valuable resource to the Yankton Sioux Tribe as well as to the States of South Dakota and Nebraska. Several miles downstream from the western boundary of the YSR, the flow of the Missouri River is impounded by Fort Randall Dam to form Lake Francis Case. Downstream from Fort Randall Dam, the river is free-flowing for several miles until it contacts backwater from Lewis and Clark Lake. Thus, within the YSR boundaries, the Missouri River is both impounded as well as free flowing, which results in a diversity of habitat critical to numerous fish and wildlife species. A water-quality monitoring program for Lake Francis Case and the Missouri River, within the boundaries of the Yankton Sioux Reservation, was initiated in FY 2002. This project is a long-term on-going cooperative effort between the Yankton Sioux Tribe (YST) and the USGS. The project consists of sampling one station on Lake Francis Case and two stations on the Missouri River for a comprehensive suite of waterquality properties and constituents. Samples are collected six times per year. Another aspect of this project involves assisting the YST in maintaining a long-term water-quality monitoring program for Lake Francis Case and the Missouri River within the boundaries of the YSR. The USGS provides training and assistance to the YST in water-quality sampling including collection methods, data processing and analyses, data archiving and data processing, and the publication of sampling results. Contact: Steven Sando,605-352-4241, sksando@usgs.gov

\section{Supporting Standing Rock Sioux Pesticide Management Plan (South Dakota)}

The USGS, in cooperation with the U.S. Environmental Protection Agency, completed a compilation of data to provide background information for a Pesticide Management Plan for the Standing Rock Sioux Tribe. Geospatial datasets include: delineation of buried valleys, approximate western extent of glaciation, surficial geology, and availability of shallow ground-water resources. The report is available online at http://water.usgs.gov/ds/ds102/. The Tribe will use the assembled information to develop a Pesticide Management Plan for their lands. Contact: Bryan Schaap,605-352-4241,bdschaap@usgs.gov 


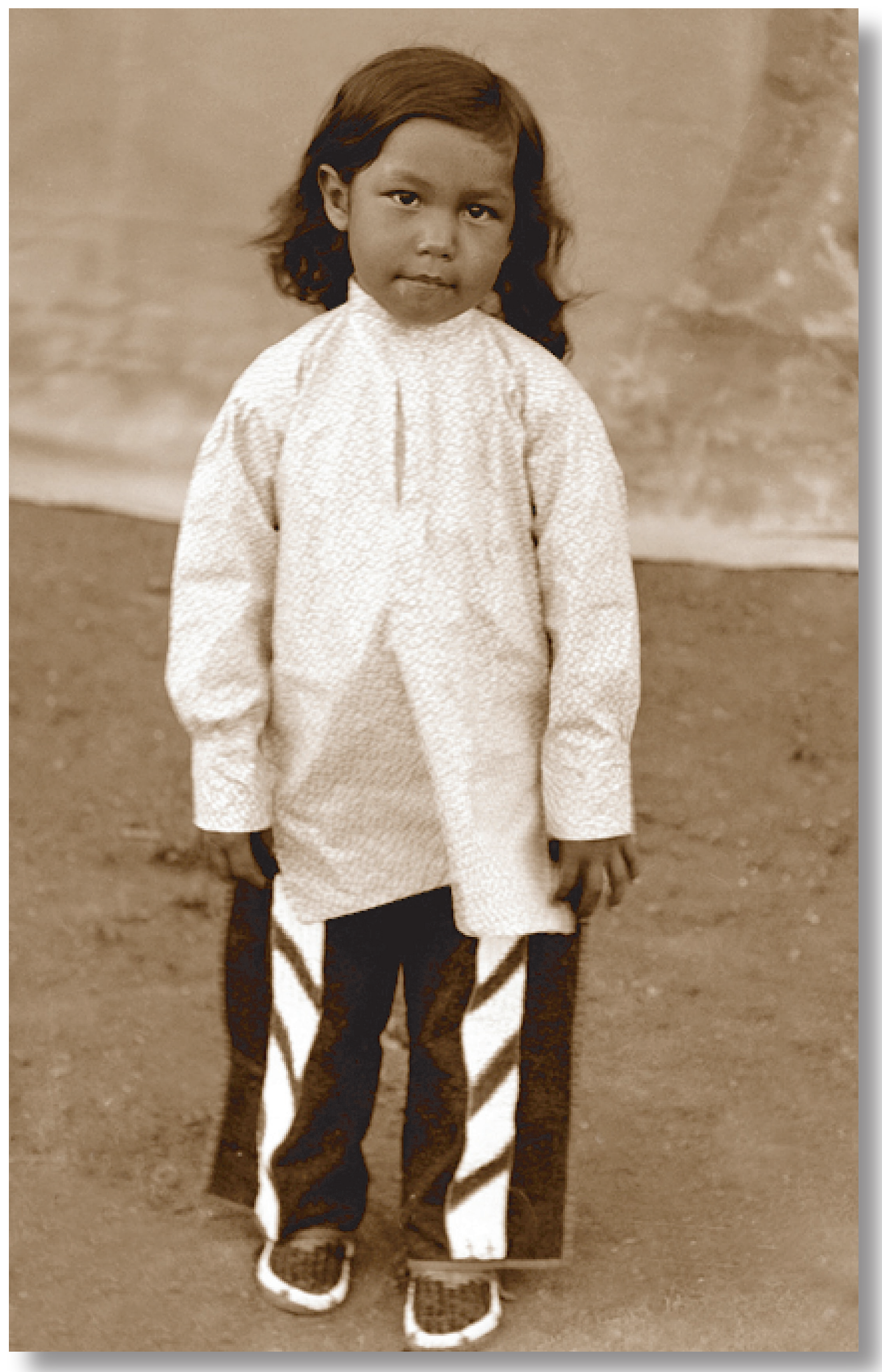

Historical image courtesy of the Blue Cloud Abbey at Marvin, South Dakota. 


\section{Rosebud Total Maximum Daily Load (South Dakota)}

The USGS South Dakota Water Resources District and the Rosebud Sioux Tribe are continuing to conduct a water-quality assessment in support of Total Maximum Daily Load (TMDL) development for the Little White River in Todd County, South Dakota. Historical data have been reviewed and compiled. USGS scientists collected new reconnaissance data to examine a wide variety of water-quality conditions including nutrients, trace elements, pesticides, and macroinvertibrates (for example, water insects). Project personnel are collecting more detailed data on suspended sediments and fecal coliform along the Little White River and its tributaries within Todd County, and they are analyzing and modeling selected data. The Rosebud Sioux Tribe will use the data and analysis to write a TMDL for the Little White River. Technology transfer, a major part of this project, will aid the Tribe with TMDL development for other streams within its lands. Contact: Joyce Williamson,605-355-4560, ext. 219, jewillia@usgs.gov

\section{Well Inventory for Abandoned Wells on Rosebud Lands (South Dakota)}

Abandoned wells are possible avenues for various surface contaminants to be introduced directly into ground-water systems. Petroleum products and other hazardous wastes have been detected by the Rosebud Sioux Tribe in several abandoned wells in Todd County, South Dakota. The Tribe is interested in plugging abandoned wells within the County. A previous well inventory to locate abandoned wells in the vicinity of community supply wells was conducted in Todd County; however, areas surrounding these community supply wells were not visited during that previous study. The current study involves evaluating existing data, inventorying wells in areas that had not been previously visited, and updating information stored in the USGS Ground-Water Site Inventory (GWSI) database relative to abandoned wells. The Tribe will use the results of this study to assist them in providing safe water to their Tribal members and residents. Contact: Kathy Neitzert605-352-4241,kmneitze@usgs.gov

\section{Potentiometric Map for the Arikaree Aquifer, Pine Ridge Reservation (South Dakota)}

The USGS South Dakota Water Resources District, in cooperation with the Oglala Sioux Tribe, is continuing a study to map the potentiometric surface of the Arikaree aquifer. The potentiometric surface is the "hydraulic head," (or upper water surface) of an unconfined aquifer (in other words, the water table); the potentiometric surface for a confined aquifer is the upper water surface in a well. The aquifer is present near the surface in approximately 80 percent of the Pine Ridge Reservation and is the single largest source of ground water for the Tribe. The objectives of this study are to provide the Oglala Sioux Tribe with a map depicting the potentiometric surface of the Arikaree aquifer and a separate data report containing a compilation of well locations and construction information. The map will be used by several Tribal departments and could help identify the best locations for new wells, predict ground-water movement, and assess aquifer vulnerability to contamination. Contact: Allen Heakin,605-394-3216,ajheakin@usgs.gov 


\section{Water Quality on the Lands of the Prairie Band of Potawatomi Nation (Kansas)}

Water quality is a major concern for the Prairie Band of Potawatomi Nation because creeks on their lands provide sources of subsistence hunting and fishing for Tribal members. Ground water is used in domestic wells on the reservation and is being considered as a source for water supply as the Tribe develops its economic base. Surface water on Tribal lands has been sampled by the USGS and Tribal personnel on a quarterly basis since June 1996 and ground-water samples have been collected annually since 2002. Tribal personnel, as well as students and personnel from Haskell Indian Nations University, assist USGS scientists with the Kansas Water Resources District in collecting and preparing samples for analysis in conjunction with the water-quality aspects of this study. Tribal personnel and personnel from Haskell Indian Nations University have also attended training courses at the USGS National Training Center. Two reports have been published as a part of this study, and a third report summarizing the surface- and ground-water quality on the reservation was released in early 2005 . The study is scheduled to continue through 2007 with a fourth interpretative report on the water quality of the Potawatomi lands to be released at the conclusion of the study. Contact: Heather Ross Schmidt,785-832-3575,hross@usgs.gov

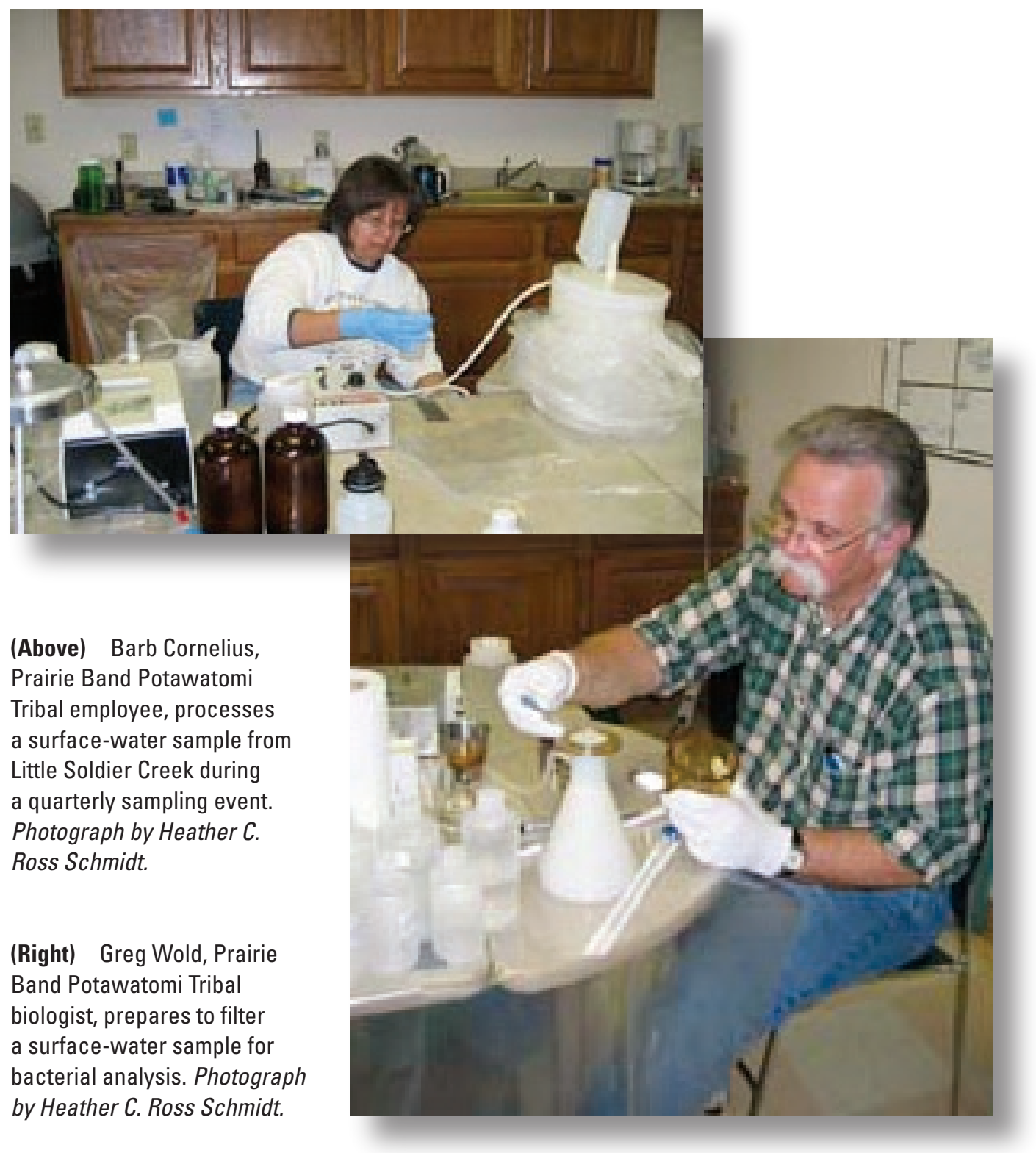




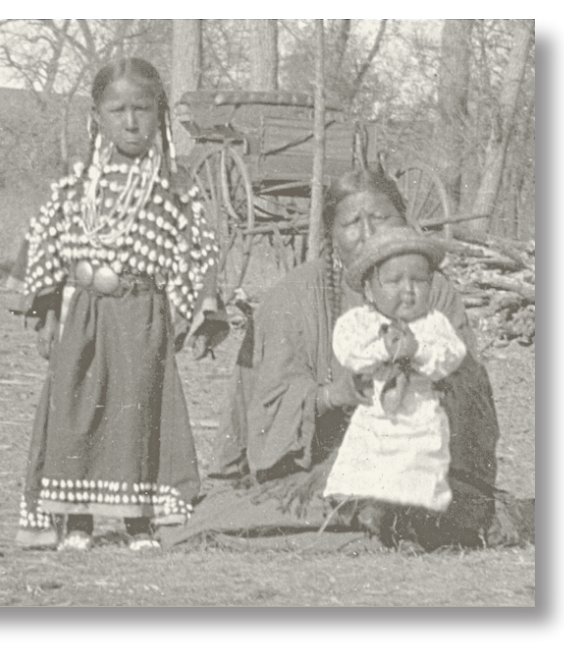

\section{Osage-Skiatook Petroleum Environmental Research Project (Oklahoma)}

USGS scientists are leading the Osage-Skiatook Petroleum Environmental Research (OSPER) Project in which research is being conducted to investigate the transport, fate, and biologic effects of saline produced water and hydrocarbon releases from oil production at two sites on Skiatook Lake, on the Osage Nation. Environmental research began in FY 2001 and continued in FY 2004 with geologic mapping, drilling of observation wells, geophysical surveys, microbial studies, geochemical sampling of soils, bedrock, ground and surface waters, plant surveys, and tree-ring dating of trees. A new stream gaging station has been established on Hominy Creek above Lake Skiatook in a related effort. This work focuses on the impacts of produced water and hydrocarbon releases from oil production on soils and ground and surface water and the oak forest and lake ecosystems they support. Skiatook Lake serves as flood control, water supply, and a major recreational fishery in the Tulsa, Oklahoma, metropolitan area. Personnel from the Osage Nation Environmental and Natural Resources Department have participated in the field investigations. The USGS provided training to Osage Nation personnel on surface-water flow measurement and sampling methods. Collaborating partners include the Osage Nation, U.S. Department of Energy, U.S. Environmental Protection Agency, U.S. Bureau of Indian Affairs, U.S. Army Corps of Engineers, University of Tulsa, Oklahoma State University, and USGS research scientists from Oklahoma, Colorado, and California. Initial results from these investigations can be found at: http://water.usgs.gov/pubs/wri/wri03-4260/. The project Web page can be found at: http://ok.water.usgs.gov/skiatook/ Contact: Jim Otton, 303-236-8020,jkotton@usgs.gov

\section{Water-Quality Concerns of the Seneca-Cayuga Tribe of Oklahoma}

Officials of the Seneca-Cayuga Tribe of Oklahoma, whose tribal jurisdictional area consists of about 70 square miles in northeastern Delaware County, are concerned about possible metals contamination of water and bed sediments in Grand Lake of the Cherokees, part of which is within their Tribal jurisdiction. In an April 2002 study, samples were analyzed for concentrations of lead, zinc, and cadmium. Elevated concentrations of the analyzed metals were detected in the water and bed sediment samples. In April 2004, the USGS Oklahoma District personnel collected surface water and bed sediment samples from the two sites in Grand Lake of the Cherokees for comparison with the 2002 data. Contact: Kelli DeHay, 918-254-6651, kdehay@usgs.gov

\section{Surface-Water Quality and Total Petroleum Hydrocarbon Loading into Skiatook Lake with the Osage Nation (Oklahoma)}

The purpose of this project is to investigate the impact of petroleum production on surfacewater quality near Skiatook Lake on the Osage Nation. Hominy Creek was impounded to form Skiatook Lake in 1984 for flood control and recreation. The lake is also used as a water supply for the cities of Sand Springs and Sapulpa. Past water-quality data collected on Hominy Creek have indicated the presence of variable but commonly high concentrations of major ions associated with surface- and ground-water discharges of produced waters. Objectives of the investigation are to determine (1) the general quality of water entering Skiatook Lake and (2) loads of constituents discharged by Hominy Creek and Wildhorse Creek into Skiatook Lake. The project began in September 2003 and will continue through 2005. The USGS provided training to the Osage Nation staff on bacterial-source tracking, making discharge measurements, and waterquality sampling as part of this project. USGS also installed a surface-water and water-quality monitoring station in FY 2003. Contact: Kelli DeHay, 918-254-6651, kdehay@usgs.gov 


\section{Reconnaissance Investigation of Pesticides and PCB's in Selected Fish Species from Lake Texoma (Oklahoma)}

The Chickasaw Nation of Oklahoma, whose jurisdictional area encompasses 13 counties in southeast Oklahoma, is concerned that Tribal members, other local residents, and recreational tourists may be exposed to hazardous amounts of pesticides and PCBs in commonly consumed fish from Lake Texoma. Personnel from the USGS Oklahoma District worked in cooperation with the Chickasaw Nation of Oklahoma and the Oklahoma Department of Wildlife Conservation to conduct a one-time sampling event of largemouth bass, channel catfish, and common carp from Lake Texoma during May 2004. Fish tissue samples were analyzed for 27 organochlorine pesticides and PCBs. Degradates of DDT and Chlordane were detected in the analyses. Contact: Shana Mashburn,405-810-4403, shanam@usgs.gov

Young Cheyenne woman with two children near Arapaho, Oklahoma, about 1910. USGS Photographic Library; photograph by T.W. Vaughan.

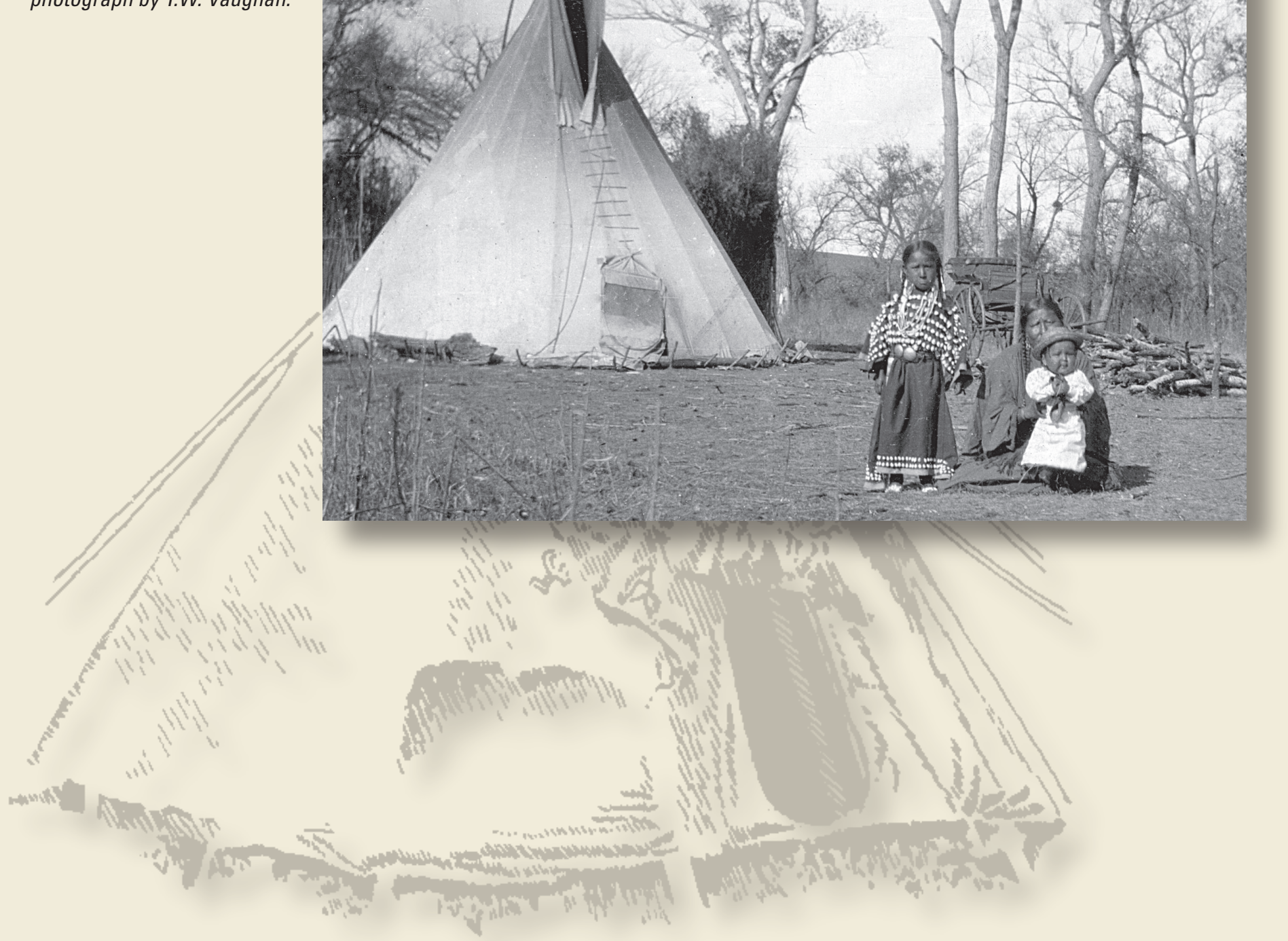




\section{Delineation of Brine Contamination in and Near the East Poplar Oil Field, Fort Peck Indian Reservation, Northeastern Montana}

Brine is a byproduct of crude-oil production. Handling and disposal of brine during the last 50 years in the East Poplar oil field has resulted in contamination of not only the shallow Quaternary aquifers, but also the Poplar River. Previous investigations have documented and delineated a portion of the extent of brine contamination in the East Poplar oil field during the early 1990s. In the 10 years since the last study, the entire extent of contamination has likely changed. Ground water in the contaminated Quaternary aquifers flows toward the nearby City of Poplar, Montana, which relies on the shallow Quaternary aquifers as its sole source of water. The objective of this project is to delineate brine contamination in the Quaternary aquifers in and near the East Poplar oil field. The project area includes the entire East Poplar oil field and extends south to include the City of Poplar. This project will provide the Fort Peck Assiniboine and Sioux Tribes with an updated delineation of brine contamination in the shallow Quaternary aquifers in and near the East Poplar oil field. The project will also enable the Tribes to determine more effective remediation of brine contamination within the oil field and provide the information that the Tribes need to evaluate the threat to the City of Poplar's water supply.

Contact: Joanna Thamke, 406-457-5900, jothamke@usgs.gov

\section{Northern Divide Grizzly Bear Project (Montana)}

The USGS Northern Rocky Mountain Science Center in Montana, in cooperation with the Confederated Salish and Kootenai Tribes, the Blackfeet Nation, and Federal and State agencies, is continuing a multi-year research project to determine the number of grizzly bears in the Northern Continental Divide Ecosystem of the United States through non-invasive measures. This project, requested by the Governor of Montana and supported by Montana Senator Burns, is designed to produce a scientifically valid estimate of the size of the grizzly bear population for the entire ecosystem. The immense study area encompasses 7.76 million acres, which extends from the Salish-Kootenai lands in the west to the Blackfeet Reservation lands in the east and from the Canadian border in the north to Montana Highway 200 in the south. Much of the project is on Tribal lands, and tribal participation contributed to a successful and productive 2004 field season. Representatives from both Tribal governments were actively involved in all stages of the planning process. They provided technical knowledge about bear activity patterns and facilitated field activities on their lands. A contract with the Blackfeet Tribe funded fieldwork conducted by Tribal members on the Blackfeet Reservation. Contact: Kate Kendall (USGS), 406-888-7994, kkendall@ usgs.gov or Dale Becker (Salish-Kootenai), 406-675-2700, daleb@cskt.orgorDan Carney (Blackfeet),406-338-2430,dcarney@3rivers.net

\section{Habitat Mapping With the Confederated Salish and Kootenai Tribes (Montana)}

Scientists from the USGS National Wetlands Research Center in Lafayette, Louisiana, are working with the Confederated Salish and Kootenai Tribes to create a community-level habitat classification system that will become an integral part of the Tribes' sophisticated Geographic Information System (GIS). The GIS system facilitates the Tribes' land use planning. The project included photointerpretation of very detailed color infrared aerial photography that formed the basis for community/association habitat types. The resulting maps were produced as a series of paper and digital base maps for 26 miles of the Flathead River below the Flathead Lake dam and for approximately 5,000 acres of wetlands on the southeastern shore of Flathead Lake. The photointerpretation was verified from light aircraft and on the ground from river access and vegetation transects. Digital products will be completed and delivered in FY 2005. A Tribal employee was trained in photointerpretation and mapping at the National Wetlands Research Center (NWRC) in Lafayette, Louisiana, for a month in FY 2004 and is applying that training on the Flathead Reservation of the Salish and Kootenai Tribes. The NWRC has provided the trainee with photointerpretation equipment for the project and potential future work. Contact: Larry Handley, 337-266-8691, larry_handley@usgs.gov 




Natural bridge in Fort Belknap Indian Reservation, Blaine County, Montana, July 30,1921 . USGS Photographic Library; photograph by W.C. Alden. 


\section{Methods for Estimating Mean- and Low-Flow Characteristics at Ungaged Sites (Montana)}

Information about the magnitude and variability of streamflow throughout Montana is required by water and land-use managers, planners, and administrators and by builders, engineers, recreationists, and the general public. The USGS has published various reports that describe methods for estimating streamflow characteristics at ungaged sites. None of these reports have been statewide in scope, none have been based on basin and climatic characteristics determined from a Geographic Information System (GIS), and none have presented methods for estimating low-flow frequency characteristics. The primary objective of this project is to develop methods for estimating mean- and low-flow characteristics in Montana based on updated streamflow and frequency data at streamflow-gaging stations. In particular, methods for estimating the mean annual and monthly discharge and annual 1-, 3-, 7-, and 14-day low flows having recurrence intervals of 2, 5, 10, 20, 50 and 100 years will be developed. In addition, methods for estimating seasonal 7-day low flows for the same recurrence intervals will be developed. The seasons will include winter (November through February), runoff-period (March through June), and summer-fall (July-October). The methods for estimating mean- and low-flow characteristics will be primarily based on regression analyses relating streamflow characteristics at gaged sites to basin and climatic characteristics at those gaged sites. Accordingly, a secondary objective of this project is to create a GIS to determine basin and climatic characteristics at gaged sites. The GIS will enable Federal, Tribal, State, and local users to more quickly and efficiently determine the required basin and climatic characteristics for application at ungaged sites. GIS-based methods for determining mean- and low-flow characteristics at ungaged sites throughout Montana will provide water managers, planners, and designers with much better tools for evaluating the adequacy of water plans and structures for mean and low-flow conditions. The Confederated Salish and Kootenai Tribes are helping to support this project. Contact: Charles Parrett, 406-457-5900, cparrett@usgs.gov

\section{Hydraulic Characteristics and Flood-Limit Delineation of the Jocko River on Part of the Flathead Reservation (Montana)}

The objective of this cooperative project is to delineate the flood limits and hydraulic floodway for 100- and 500-year events for a 20-mile reach of the Jocko River from near Arlee, Montana, to the river's mouth near Dixon on the Flathead Reservation of the Confederated Salish and Kootenai Tribes. USGS hydrologists from the Montana Water Resources District surveyed channel-geometry (cross-section) data for the Jocko River and are using the data in a hydraulic model to calculate water-surface profiles and other hydraulic parameters such as flow area, conveyance, flow widths, mean flow depths, and velocities. The hydraulic data will be used to delineate the flood plain and floodway. Determination of hydraulic characteristics is a prerequisite to the delineation of flood limits and a hydraulic floodway for the 100-year flood. The 100-year flood is commonly used as a regulatory flood for flood-plain management and flood insurance purposes. Adoption of flood-plain management regulations for the Jocko River would enable land-use and fishery managers for the Salish and Kootenai Tribes to better plan and guide future development to minimize riverine impacts and would also enable citizens to purchase subsidized flood insurance. Contact: Charles Parrett, 406-457-5928, cparrett@usgs.gov 


\section{Monitoring Ground Water in Potential Coal-Bed Methane Zones, Northern Cheyenne Tribe (Montana)}

Coal-bed methane (CBM) has a large potential for development in southeastern Montana. In order to release methane from the coal beds, large amounts of ground water must be withdrawn from these beds. On the Northern Cheyenne Reservation, many of the coal beds, which are important sources of water used for livestock and domestic supplies, are targeted for CBM development in areas near the Reservation. In FY 2002, the USGS Montana District, in cooperation with the Northern Cheyenne Tribe, installed six observation wells in the coal beds to monitor changes in water quality and water levels as CBM development proceeds near the Reservation boundary. In a related effort, the USGS Central Region Energy Resources Team, in cooperation with the U.S. Bureau of Indian Affairs, analyzed cores collected during the observation-well drilling for gas content. In FY 2003 and FY 2004, the USGS worked with the Tribe to monitor water levels monthly in four of the observation wells and operate water-level recorders in the other two wells. As a result of these efforts, the Tribe will have additional data to help them manage their natural resources. Contact: Mike Cannon, 406-457-5900, mcannon@usgs.gov or Jason Whiteman (Northern Cheyenne Tribe), 406-477-6503

\section{Evaluation of the Quantity of Ground Water in Coal-bed Aquifers in Parts of the Northern Cheyenne Reservation (Montana)}

The Powder River structural basin of Montana and Wyoming is the target of extensive exploration and development of coal-bed methane. Development of coal-bed methane on lands adjacent to the southern and southeastern boundaries of the Northern Cheyenne Reservation would likely have negative effects on valuable ground-water resources within the Reservation. Such effects include depletion of the water resource and lowering of water levels over large areas. The coal-bearing formation targeted for methane development supplies most of the domestic and livestock water used on the Reservation. This study, begun in September of FY 2004, is evaluating the quantity of ground water in parts of the coal-bed aquifers. Specific non-Reservation lands have high potential for development of coal-bed methane. The study is being conducted on adjacent Reservation lands that are most likely to be impacted by methane extraction. Determining current ground-water resources in coal beds within the Reservation will provide a baseline for evaluating whether off-Reservation coal-bed methane development affects the future availability and quality of the Tribe's drinking water and stock water. Existing observation wells completed in coal beds will be used for measuring water levels, hydraulic properties of coal beds, and water quality. Geologic cross-sections, constructed using coal outcrop, topographic, and drill-hole data, will be used to estimate the volumes of coal that comprise the aquifers. Volumes of ground water in coal-bed aquifers will be estimated using measured water levels, calculated volumes of coal, and local and regional values of specific yield and storage coefficient. Estimated water volumes will include water potentially recoverable from confined storage plus water that is contained in the coal fracture (cleat) system. Water levels in a network of wells will be measured to determine heads in confined coal-bed aquifers and the position of the water table in partially saturated coal beds. Water samples will be collected from a subset of the monitoring wells to define the quality of water in various coal beds at different depths. Contact: Mike Cannon,406-457-5900,mcannon@usgs.gov 


\section{Mapping Exotic Plants in the Southwest}

In conjunction with land managers, biologists at the USGS Forest and Rangeland Ecosystem Science Center's Colorado Plateau Field Station are developing a database on exotic plants in the Southwest. The database is an important regional tool for inventorying, monitoring, and sharing data on exotic (non-native) plant species that are invading the area. USGS scientists are gathering data on the plants and compiling it according to Federal standards. The database can also be used to generate maps of locations of the plants. The goals of this effort include developing and maintaining the Southwest Exotics Plant Database; maintaining a distribution system that integrates educational, management, and scientific information to aid in control of the exotic plant species; and facilitating a collaborative partnership among Tribal, Federal, State, and private land managers. The database is available on the Southwest Exotic Plant Information Clearinghouse (SWEPIC) Web site (http://usgssrv1.usgs.nau.edu/swepic/) and, as such, the data and the SWEPIC information are freely available to Tribal members and to the public. Contact: Kathryn Thomas, 520-556-7327, ext.235, kathryn_a_thomas@usgs.gov

South side of part of the Zuni Indian Pueblo in 1873 in what is now New Mexico. Today, residents of Zuni Pueblo are world famous for their beautiful art, including silver work, stone fetishes, and pottery. USGS Photographic Library; photograph by T.H. O'Sullivan.

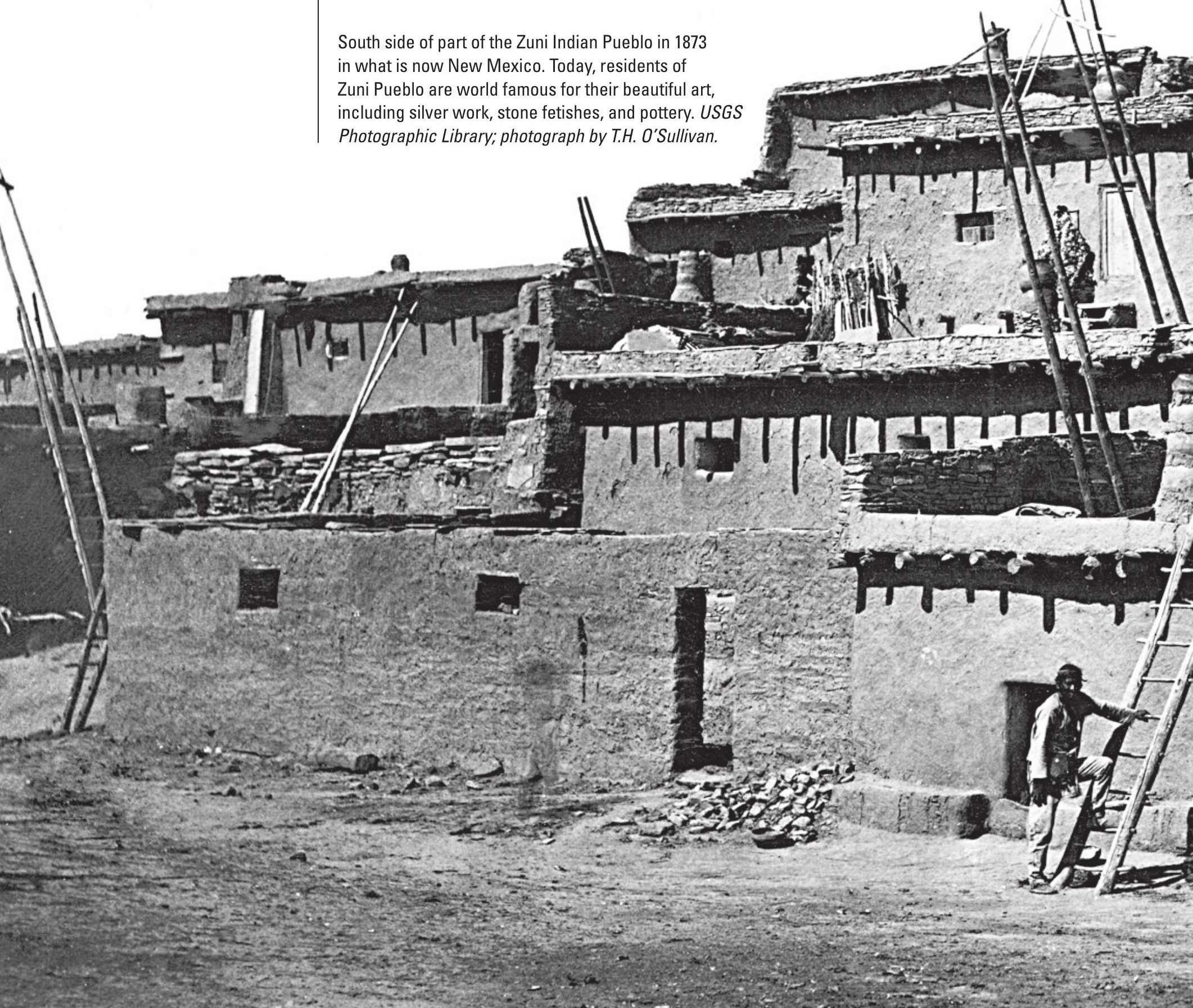




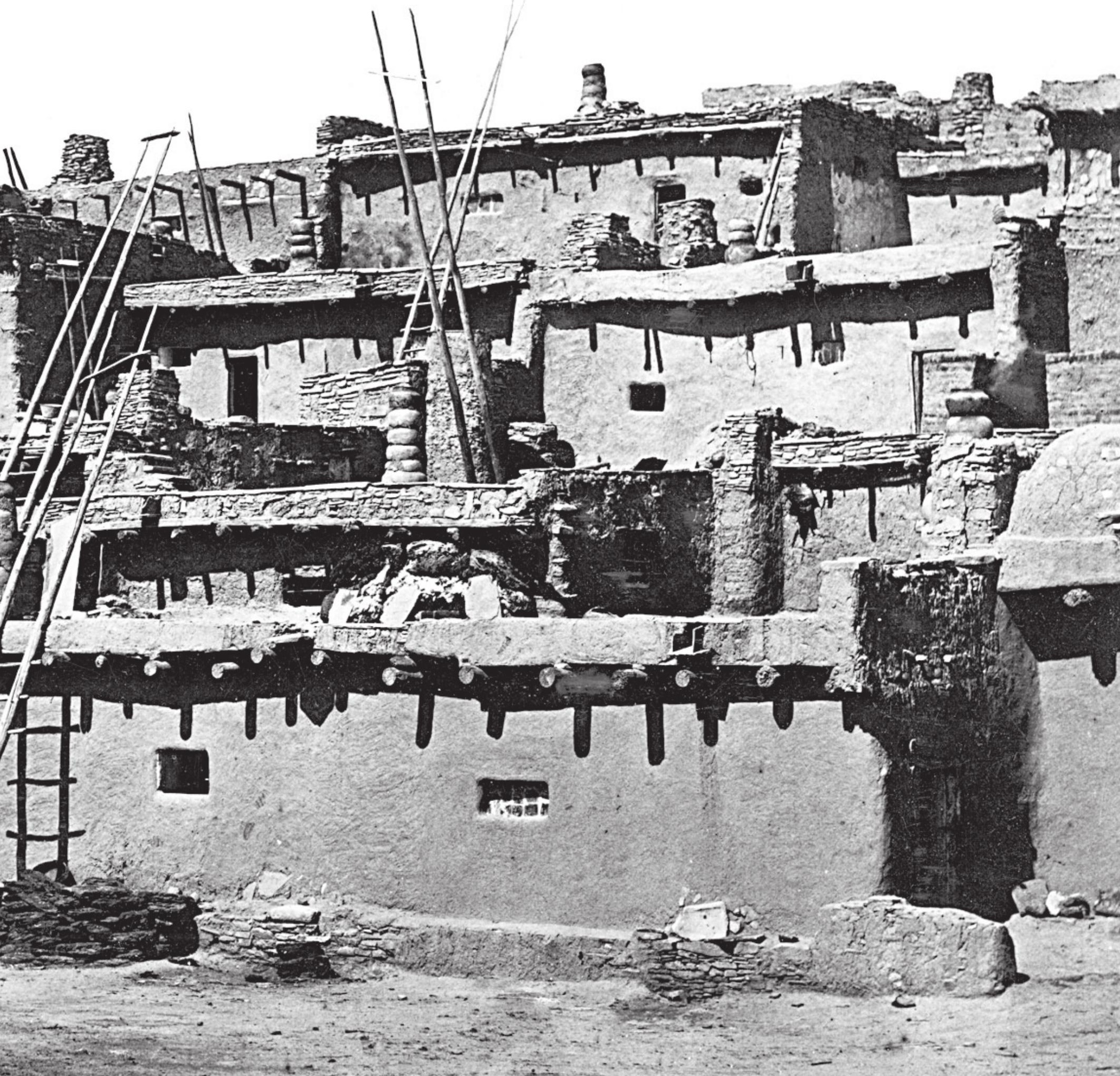




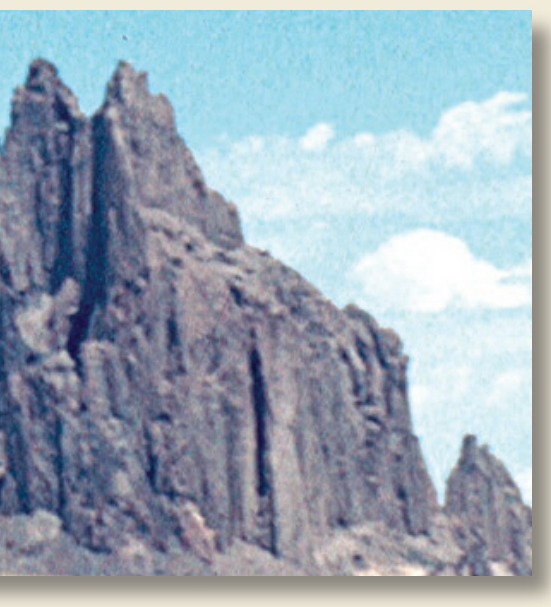

\section{Geologic Framework of Rio Grande Basins (New Mexico)}

The USGS is conducting geologic and geophysical studies to provide a framework for understanding aquifers in several critical ground-water basins along the Rio Grande, which extends from Colorado to Mexico. One focus of this project is the Española ground-water basin in the greater Santa Fe, New Mexico, region, which includes lands belonging to the Pueblos of Cochiti, Nambe, Pojoaque, Tesuque, San Ildefonso, San Juan (Ohkay Owingeh), and Santa Clara. A new focus of this project in FY 2004 was the San Luis Basin, which includes Taos Pueblo. An objective of the project is developing a better understanding of the three-dimensional form of the ground-water basins to improve the understanding of ground-water flow and resources. The project includes geologic mapping in cooperation with the New Mexico Bureau of Geology and Mineral Resources and the University of New Mexico; geophysical mapping of the subsurface in cooperation with Los Alamos National Laboratory and the Summer of Applied Geophysics Experience educational program; investigations into how faults affect the aquifer system; and studies of geologic history to predict the distribution of underground aquifers. Geologic and geophysical maps in the basin provide the Pueblos with information that aids in ground-water protection and assessment of water and other natural resources. Activities specific to FY 2004 included an annual public workshop, hosted by the USGS project scientists, where members of Pueblo Nations could learn about the studies in the Española basin and interact with scientists. New high-resolution aeromagnetic data were collected over the town of Taos and vicinity, which included large parts of Taos Pueblo. These data were distributed to Taos Pueblo Governor John A. Mirabal along with interpretative reports. Project scientists met informally with the Assistant Pueblo Administrator of Zia Pueblo to explain the project's progress in determining the influence of faulting on ground-water flow in one area of Zia Pueblo. Contact: Mark Hudson, 303-236-7446, mhudson@usgs.gov or Tien Grauch, 303-236-1393, tien@usgs.gov

\section{Rio Grande Water-Quality Conditions and the Endangered Rio Grande Silvery Minnow (New Mexico)}

USGS scientists from the USGS Yankton (South Dakota) Field Research Station of the Columbia Environmental Research Center have been conducting on-site assessments of the effects of major point sources discharges to the Middle Rio Grande, New Mexico, on the endangered Rio Grande silvery minnow. This research is part of a collaborative project with the U.S. Fish and Wildlife Service (FWS) to assess ambient water quality conditions in relation to habitats of the Rio Grande silvery minnow. During FY 2004, project scientists evaluated the toxicity of water and sediment in an embayment that receives municipal storm-water runoff from the City of Albuquerque, New Mexico. This embayment, which is on the Pueblo of Sandia, may be an important nursery habitat for silvery minnow eggs and larvae. River water was collected on the Santo Domingo Pueblo upstream of the embayment for use as the test control. Field studies in 2004 documented a large fish kill in the embayment. The toxic conditions were subsequently identified in the stormwater. The toxicity was caused by anoxic water with high oxygen demand that was stored in the lower part of the storm-water drainage system. The USGS scientists briefed representatives of the Sandia Pueblo about the fish kill and cooperated with their post-event sampling. The USGS provided water quality and biological data relating to storm-water management practices for two meetings of stakeholders. The meetings, attended by Sandia Pueblo representatives, were held to discuss monitoring requirements to reduce or eliminate the source of toxicity. Final reports will be shared with the Santo Domingo Pueblo and the Pueblo of Sandia. The results will be incorporated into the FWS multi-year investigation of water quality requirements of the Rio Grande silvery minnow in accordance with the objectives of the Rio Grande Silvery Minnow Recovery Plan. Contact: Kevin Buhl, 605-6659217,kevin_buhl@usgs.gov 


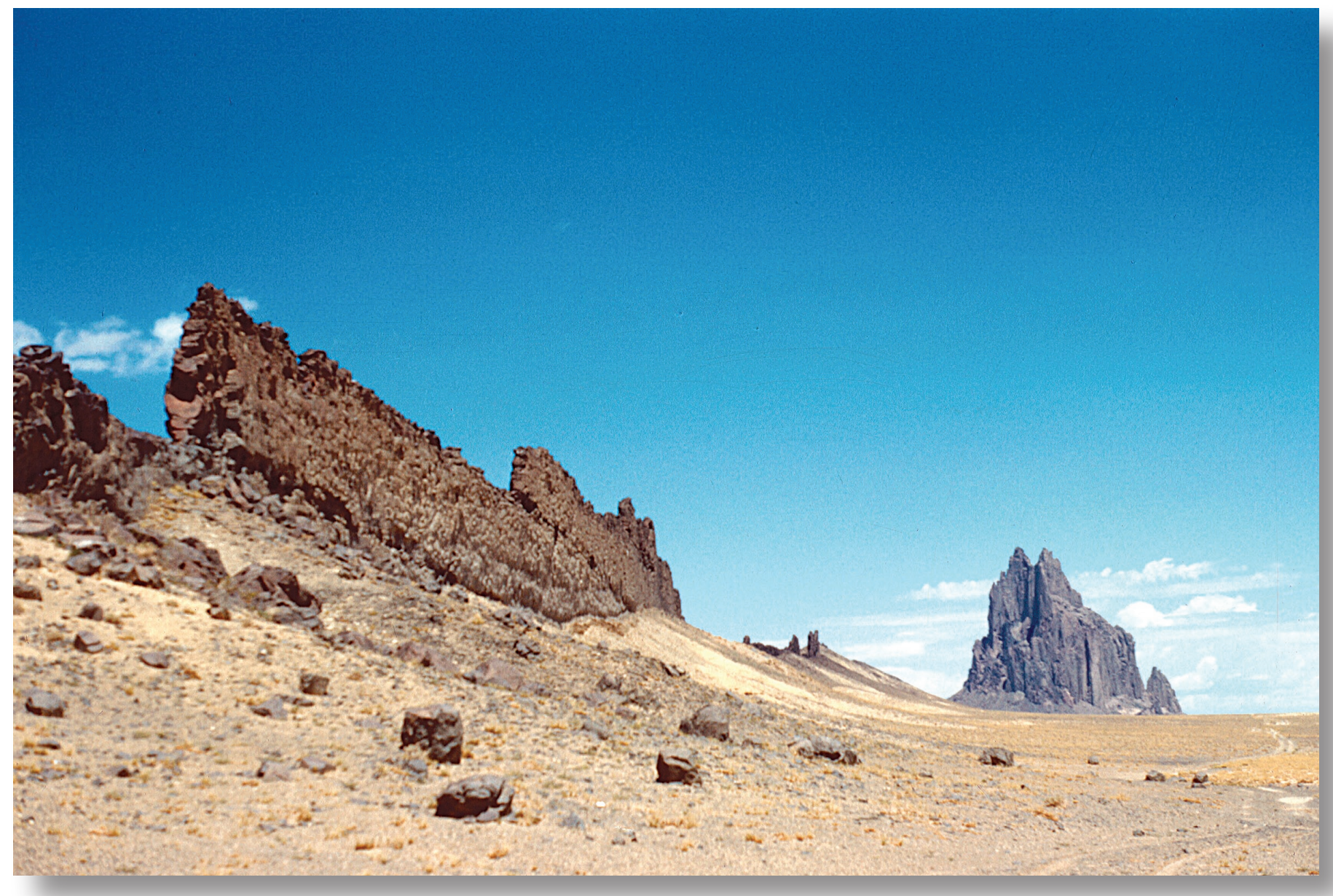

An eroded igneous rock dike dominates the left foreground; in the distance on the right is Shiprock, an eroded volcanic neck. Navajo Nation, New Mexico. USGS Photographic Library; photograph by E.D. McKee, date unknown.

\section{Seismological Laboratory Facility Serves the World from the Pueblo of Isleta (New Mexico)}

The USGS has a 5-year lease with the Pueblo of Isleta for the use of all buildings and facilities of the original USGS Albuquerque Seismological Laboratory (ASL). This locale includes seismometer test tunnels and boreholes on Isleta lands south of Albuquerque, New Mexico. The ASL has used these facilities, known as the ASL-Isleta site, since 1961 for a global network maintenance center, data collection center, and for low-noise testing of modern seismic instruments in support of global seismograph networks used for monitoring seismic activity worldwide. The USGS will continue to use the site for all of these purposes during the term of this lease. ASL's mission includes operation and maintenance of 89 seismic stations of the Global Seismograph Network (GSN) in 60 countries and the installation, operation, and maintenance of 35 Advanced National Seismic System/ USArray seismic stations in the U.S. that are part of the National Science Foundation-funded Earthscope Project. The site on the Pueblo of Isleta is notable for its low seismic noise characteristics. Seismic equipment manufacturers want their instruments to be tested here by the USGS as a key step in qualifying the instruments for use in seismic networks. The USGS/ASL also operates a standard GSN station at this location, one of 140 such stations operating worldwide in more than 80 countries and islands. Data received in real time and on tapes mailed from the GSN stations support earthquake monitoring and research at the USGS National Earthquake Information Center and the Incorporated Research Institutions for Seismology (IRIS), tsunami warning efforts by the National Oceanic and Atmospheric Administration, and nuclear test monitoring efforts for the Comprehensive Test Ban Treaty. The Pueblo of Isleta and the general public receive occasional educational talks and presentations on how the seismic equipment functions for monitoring earthquakes. The USGS appreciates the Pueblo of Isleta for permitting this globally significant scientific endeavor on their lands. Contact: Charles R. (Bob) Hutt, 505-846-5649, bhutt@usgs.gov Additional information: http://aslwww.cr.usgs.gov Live Seismograms: http://www.liss.org/ 


\section{Inventory of Vascular Plants and Vertebrate Animals, Southern Colorado Plateau (Arizona, Colorado, New Mexico, Utah)}

A broad area inventory of the southern Colorado Plateau is nearing completion. The project has been a collaborative effort of the National Park Service, the USGS Southwest Biological Science Center, and Native American Tribes of the area, including the Navajo Nation, Ute Mountain Ute, and the Havasupai. Inventory studies of vascular plants and vertebrate animals have been conducted in all of the National Park Service lands in the four-state region (northern Arizona, northwestern New Mexico, southwestern Colorado, and southern Utah). Some of these areas are partly or wholly on Tribal lands (Navajo National Monument and Canyon de Chelly National Monument are on Navajo lands), and most other areas border on Tribal lands. Navajo Natural Heritage staff had lead responsibility for some of the inventories (as at Navajo National Monument, Canyon de Chelly National Monument, and Hubbell Trading Post National Historic Site), while USGS researchers were primarily responsible for the remaining areas. The studies have yielded a more complete picture of the plant and animal communities of this poorly studied region, have added new records of species occurrence at all of the areas studied, and have produced substantial new information on the biology, ecology, and natural history of the region. Results of the studies to date are available at: http://www1.nature.nps.gov/im/units/scpn/inventories.htm Contact: Charles Drost, 928-556-7187, charles_drost@usgs.gov

\section{Mapping and Landscape Vulnerability on the Navajo Nation (Arizona, Colorado, New Mexico)}

USGS geologists, ecologists, and geochemists are working with archaeologists and educators of the Navajo Nation to establish relations of land use and climate change to changes in the land surface. Mapping of geology, stream erosion, sedimentation, flooding, and the distribution of native and invasive plants are being compiled with information on climate, land use, and geologic controls on the availability and quality of water. The results of this work are being produced as digital maps in a Geographic Information System (GIS), with bedrock and surficial mapping as a foundation to document land surface conditions. Current work is focused on the Winslow and Sanders 1:100,000-scale quadrangles. The Navajo Nation (roughly the size of West Virginia) has the largest land base and reservation population of all tribes in the United States. In addition, half the population is currently under the age of 23 (U.S. Census, 2000). The geologic information provided by USGS studies is crucial for planning urban development and infrastructure such as highways, buildings, bridges, and domestic septic and landfill systems. Our maps also provide information on geologic hazards, such as sand and dust storms and flood vulnerability, which will lead to a better understanding of ecosystem responses to land use and global warming. Mapping has been used to examine spatial relations of dune deposits on the Navajo Nation to wind erosion, by combining the distribution of surface deposits with climate information in a GIS. The map can be updated using equations that relate climatic factors to wind erosion, and it can be used to predict the current potential for sand-dune mobilization or the change in sand-dune mobilization with drought or global warming. Continuing severe drought conditions have produced diminishing soil moisture conditions during the past several years, leaving several areas without enough moisture to support stabilizing vegetation. See http://wrgis.wr.usgs.gov/wgmt/navajo/index.html, http://climchange.cr.usgs.gov/info/sw/ and http://climchange.cr.usgs.gov/hopibuttes/ Contact: Margaret Hiza (geologic studies), 928-5567366, mhiza@usgs.gov or Kathryn Thomas (vegetation studies), 520-670-5534, kathryn_a_ thomas@usgs.gov

(Facing Page) Navajos around a campfire, north-central Arizona, about 1905. USGS Photographic Library; photograph by N.H. Darton. 


\section{Navajo Nation: Flood-Flow Frequency Investigation (Arizona, Colorado, New Mexico)}

The United States Congress provided authorization for flood-plain mapping throughout the Navajo Nation by the U.S. Army Corps of Engineers (USACE). The U.S. Bureau of Indian Affairs, Navajo Nation, and USACE wanted an update of techniques for estimating floodflow frequency for ungaged sites on the Navajo Nation. New regression models are needed to improve understanding of the flood regions. The objectives of this investigation are to analyze and compile hydrologic data and then to use the analyses and compilations to create predictive models of flow frequency for selected streams on the Navajo Nation. Working with Navajo Nation staff, USGS hydrologists will develop a database of basin and climatic characteristics for the gaging stations. An existing database will be supplemented with new characteristics using a USGS Geographic Information System (GIS). Regional regression models of basin and climatic characteristics will also be added to the GIS to estimate flood-flow frequency at ungaged, unregulated stream sites. Research for new basin and climatic variables includes the use of a USGS GIS tool and data from the National Elevation Dataset. The National Oceanic and Atmospheric Administration (NOAA) published Atlas 2 and a more recent edition, Atlas14, both titled, "Precipitation-Frequency of the western U.S." Average basin values of 24-hour, 100-year, and 6-hour, 100-year maximum precipitation have been determined for NOAA Atlas 2 and 14. Other variables include slope, aspect, elevation, and winter and annual precipitation. Contact: Scott Waltemeyer, 505-830-7953, sdw@usgs.gov

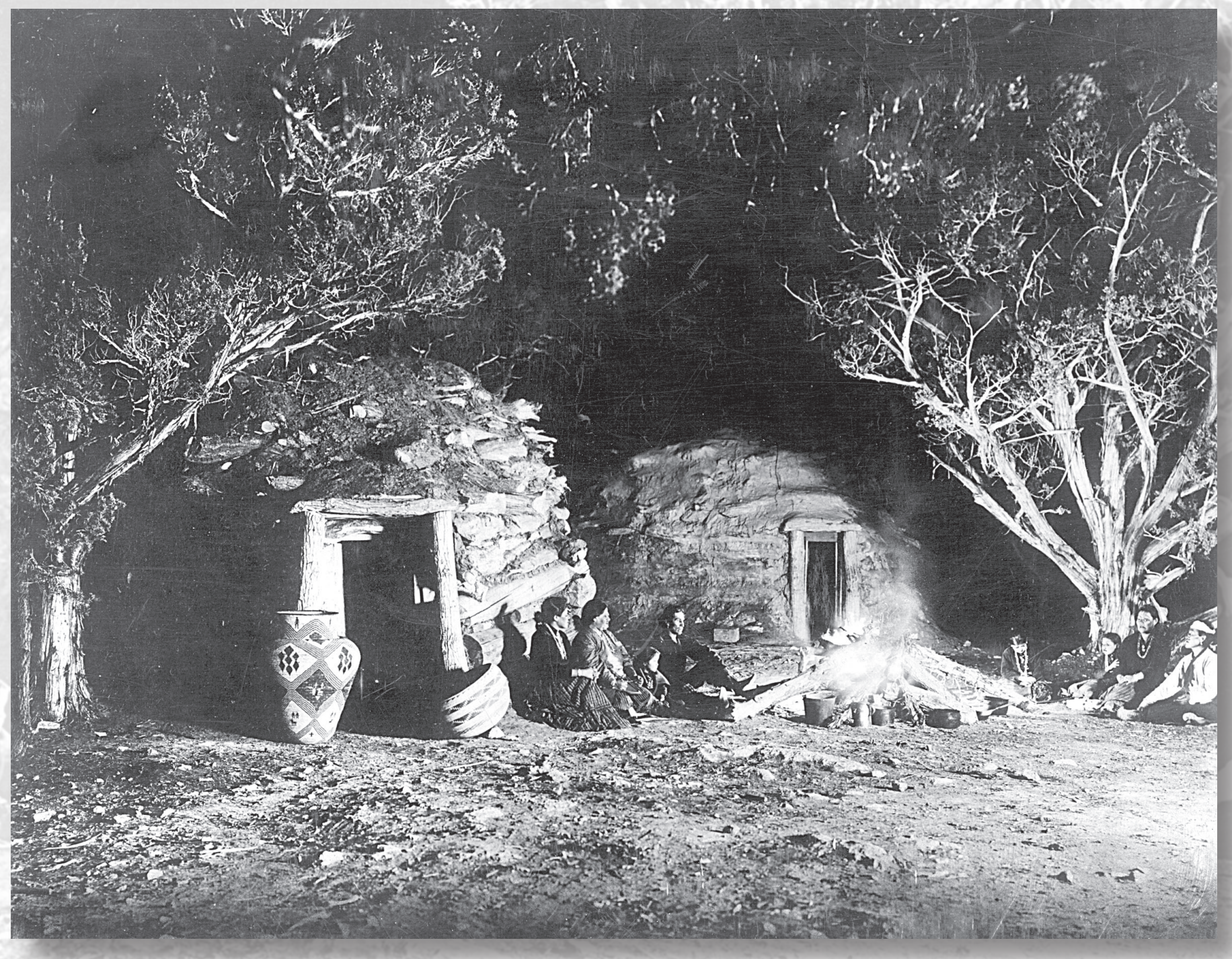




\section{Hydrogeologic Studies Near Pipe Spring National Monument and Lands of the Kaibab Paiute Tribe (Arizona)}

Pipe Spring National Monument in Arizona, near the border of Utah, includes several low-discharge springs that are the primary natural features of the monument. The National Park Service is concerned about the declines in spring discharge. Water resources are very limited near Pipe Spring National Monument and the Kaibab Paiute Reservation. Residents in the vicinity of the monument, Tribal members, and the local Arizona communities must share the limited water supply. A 3-year project began in FY 2002, with USGS scientists conducting geologic mapping and seismic imaging of the subsurface near and on Pipe Spring National Monument west of Fredonia, Arizona, and the surrounding lands belonging to the Kaibab Paiute Tribe. The mapping includes four USGS 7.5' quadrangles and encompasses the western two-thirds of the Kaibab Paiute Reservation. This USGS project was conducted in association with the National Park Service and in cooperation with the Kaibab Paiute Tribe. Seismicrefraction and frequency-domain electromagnetic-induction methods were employed in an attempt to better understand the relation between spring discharge and geologic structure. The particular method used for the seismic-refraction surveys was unable to resolve structural features in the monument. Electromagnetic surveys delineated differences in apparent conductivity of the shallow subsurface deposits. The differences are attributable to differences in saturation, lithology, and structure of these deposits. This was a follow-up study from previously completed work describing the local ground-water system in relation to springs in the monument and on Tribal lands. The geologic map was published in FY 2004 as Billingsley, G.H., Priest, S.S., and Felger, T.J., 2004, Geologic Map of Pipe Spring National Monument and the Western Paiute-Kaibab Indian Reservation, Mohave County, Arizona: U.S. Geological Survey Scientific Investigations Map SIM-2863, scale 1:31,680, $22 \mathrm{p}$. This publication is also available on the Web at http://pubs.usgs.gov/sim/2004/2863/. An initial report on the ground water hydrology was published in 2004 as Truini, Margot, Fleming, J.B., and Pierce, H.A., Preliminary investigation of structural controls of ground-water movement in Pipe Spring National Monument, Arizona, U.S. Geological Survey Scientific Investigations Report 2004-5082. The report is also available on the Web at: http://az.water.usgs.gov/pubs/online-sir.htm. The results of USGS geologic and hydrogeologic interpretations of the geologic mapping and seismic profiles will be used as the basis for possible additional studies. These studies provide land managers with information on the implications of ground-water use and availability in this area. Contact: George Billingsley (geology), 928-556-7198, gbillingsley@usgs.gov or Robert Hart (water), 928-556-7137,bhart@usgs.gov or Margot Truini (water),928-556-7352, mtruni@usgs.gov

\section{Geologic Mapping of the Eastern Grand Canyon Region (Arizona)}

A project that is cooperatively funded by the USGS and the National Park Service intends to improve understanding of the surficial and underground water resources of the eastern part of Grand Canyon National Park and adjacent Navajo lands. The 3-year project began in FY 2003 and encompasses an area of about 2,000 square miles. The project is being conducted with cooperation of the Cameron, Coalmine Canyon, and Leupp Chapters of the Navajo Nation. Contact: George Billingsley, 928-556-7198, gbillingsley@usgs.gov or Sue Priest, 928-5567148,spriest@usgs.gov

(Facing Page) Nelson Luna, Director, Pueblo of Zuni Fish and Wildlife Department, holding a non-native trout. Non-native fish are threatening the survival of an endangered native fish species, so the non-native fish are being mechanically removed from the Colorado River as part of a USGS project being conducted with assistance from Tribal personnel. Photographer unknown. 


\section{Parasites of Native and Non-Native Fishes in the Lower Little Colorado River (Arizona)}

Scientists from the USGS National Wildlife Health Center studied parasites in fish in the lower 14 miles of the Little Colorado River, Grand Canyon, Arizona, an area administered by the Navajo Natural Heritage Program (Navajo Nation) and the National Park Service (Grand Canyon National Park). Fish populations were sampled by the USGS in FY 2000 and FY 2001. In FY 2001, a total of 1,235 fish representing eleven species (all four native species and seven non-native species) were captured and examined for internal parasites. Results from both years indicate that between 50 and 60 percent of the endangered humpback chub (Gila cypha) were infected with the Asian fish tapeworm (Bothriocephalus acheilognathi). Such infections can cause disease and retard growth. The disease could be severe enough to cause mortality. A reduced growth rate could increase the time that fish are susceptible to predation and also cause the fish to be small when they enter the main stem of the Colorado River during monsoon season. Smaller fish do not survive as well as larger fish in the cold waters of the main stem. In addition, zooplankton (critical to tapeworm transmission) were collected, identified, and counted. Temperature was monitored in various tributaries of the Little Colorado River to evaluate environmental conditions involved in the transmission of the tapeworm. Laboratory studies of bony-tailed chub, a surrogate for the endangered humpback chub, were initiated in FY 2001 and were completed in December 2003. These experiments were designed to assess the impact of the Asian fish tapeworm on fish growth, body condition, and ability to withstand thermal stress. The results indicate that the tapeworm did affect growth, causing infected fish to grow more slowly. In some experiments with fish that were fed a ration of 0.5 percent body weight, 24 percent of exposed fish died as compared to 5 percent unexposed fish. Other parameters such as body condition and effects of thermal stress were not significantly different in the laboratory-infected fish than in the control fish. Contact: Rebecca Cole, 608-270-2468, rebecca_cole@usgs.gov

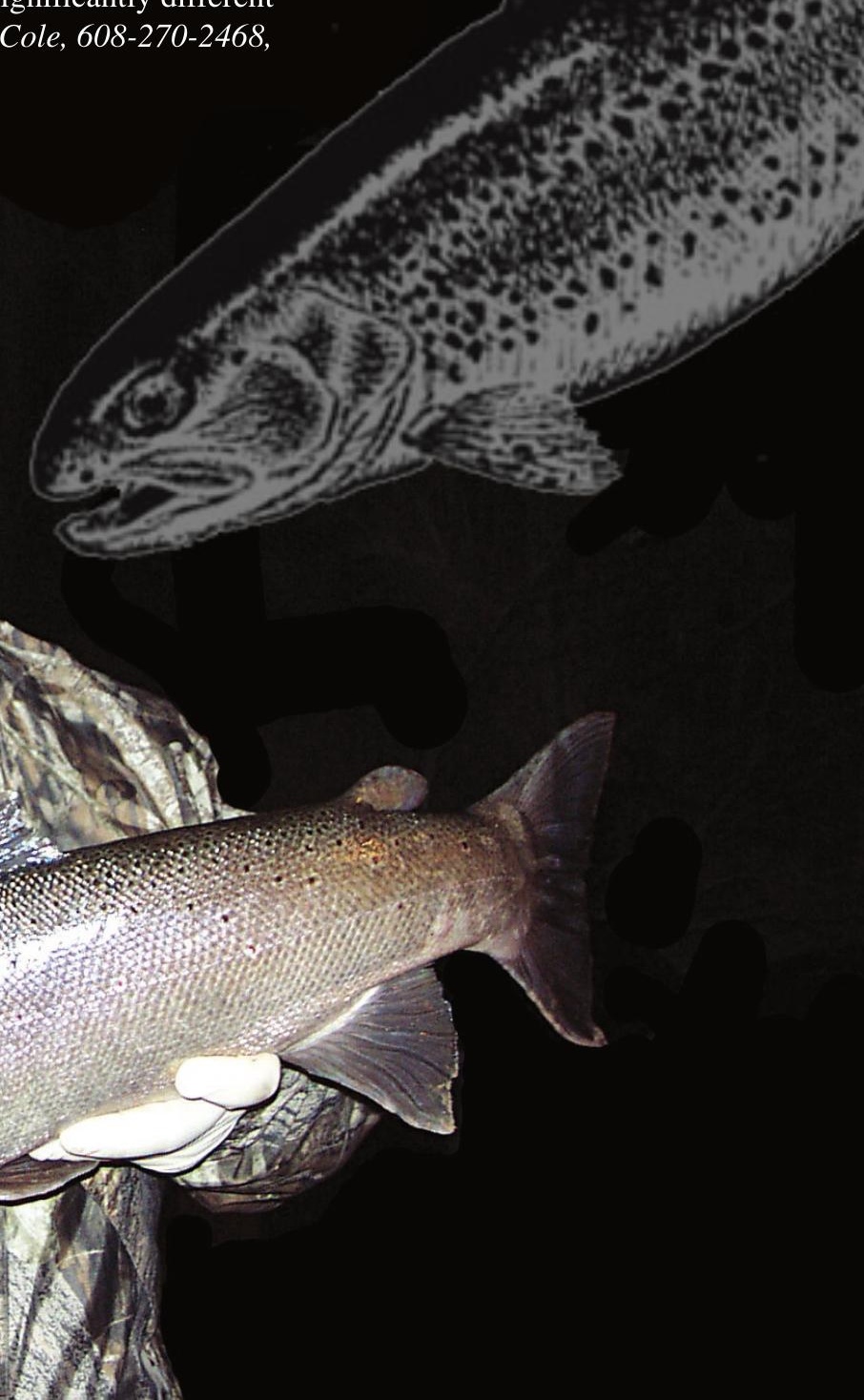




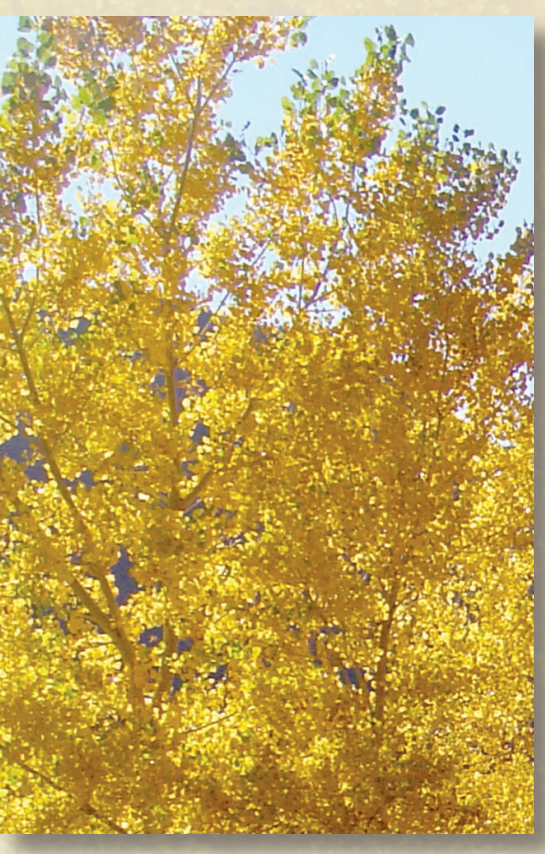

\section{Vegetation Surveys on Native Lands (Arizona)}

USGS scientists from the Southwest Biological Science Center/Colorado Plateau Field Station conducted vegetation surveys on the Navajo Nation, the Hopi Tribal lands, and the Gila River Indian Community in FY 2003. As part of the Southwest Regional Gap Analysis regional conservation assessment of biota, a land-cover map of the southwest is being developed. The USGS vegetation team is developing the land-cover map products for most of Arizona and some surrounding areas. Results and products of the studies will be shared with Tribal governments. The land cover maps and other products are in preparation. Contact: Kathryn Thomas, 520-670-5534,kathryn_a_thomas@usgs.gov

\section{Vegetation, Sand Sheet, and Dune Stability on the Navajo Nation (Arizona, Colorado, New Mexico)}

The Navajo Nation has experienced severe drought in the last few years. Much of the Navajo Nation consists of sand sheets and dunes. Concurrent with the drought have been reports of once stabilized sand becoming active dunes and of increasing infestation of Russian thistle on the more active sand sheets and dunes. Vegetation is known to stabilize sand but details of the characteristics and composition of native vegetation and the influence of non-native invasive species on native vegetation health have not been available. A biologist from the USGS Colorado Plateau Research Station of the Southwest Biological Science Center and a USGS geologist conducted an integrated study of vegetation on sand and dune sites in the southeastern Navajo Nation. Field measurements were made in 2004 and are being evaluated. The final report is in preparation. Results will be presented to the scientific community and to Navajo Nation chapter houses in the study area. Contact: Kathryn Thomas (vegetation), 520-670-5534, kathryn_a_ thomas@usgs.govor Margaret Hiza (geology),928-556-7366, mhiza@usgs.gov

\section{USGS and NPS Collaborate with the Navajo Nation in Colorado Plateau Vegetation Mapping (Arizona, Colorado, New Mexico)}

The USGS Colorado Plateau Research Station (CPRS) of the Southwest Biological Science Center has been a key team member in developing vegetation mapping for National Parks on the Southern Colorado Plateau. The Navajo Nation has been instrumental in the project implementation in three of these park units: Wupatki National Monument, Petrified Forest National Park, and Canyon de Chelly National Monument. Wupatki National Monument's vegetation mapping effort extended to 1-mile outside the boundary of the monument, with the eastern extension on Navajo Nation land. The project team, which included the USGS CPRS, USGS-NPS Park Vegetation Mapping Program, U.S. Bureau of Reclamation, and Nature Serve, completed the final report and vegetation map for Wupatki National Monument in November 2004. Petrified Forest National Park's vegetation mapping effort extended to 0.62 mile outside the monument, with the northern area of the project on Navajo Nation land. The USGS CPRS team completed vegetation field sampling in October 2003. Final reporting and map development is scheduled for 2006. The National Park Service works in partnership with the Navajo Nation to manage Canyon de Chelly National Monument, which is located on the Navajo Nation. Contact: Monica Hansen, 928-556-7466 ext.252, mlhansen@usgs.gov or Kathryn Thomas, 520-670-5534, kathryn_a_thomas@usgs.gov or Anne Cully, 785 539-5503, Anne_ Cully@nps.gov 


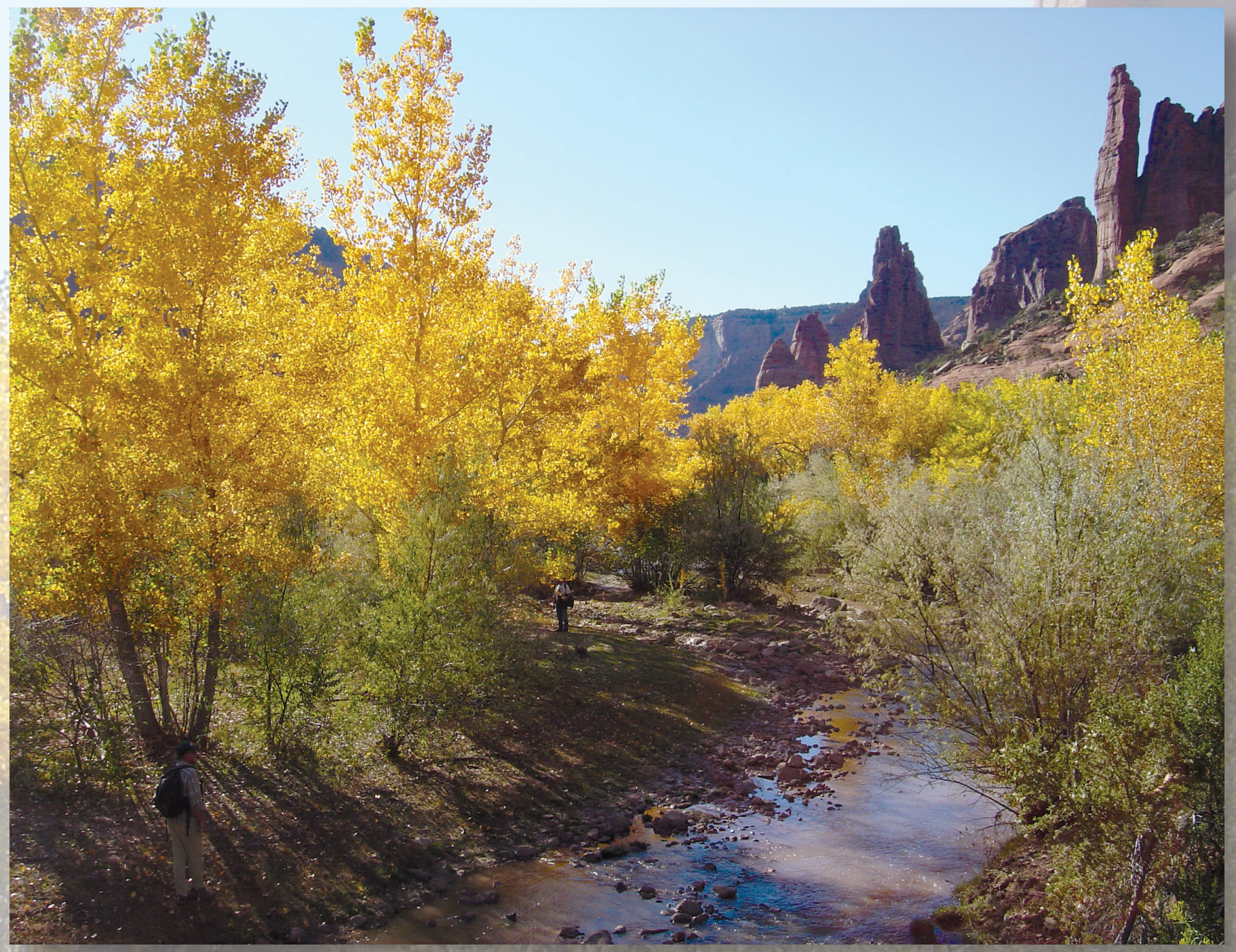

Fall in Canyon de Chelly, Arizona. Photograph by Rob Klotz, USGS.

\section{Land Cover Change and Analysis on the Navajo and Hopi Reservations (Arizona, Colorado, New Mexico)}

The USGS Southwest Geographic Science Team is working with Navajo and Hopi officials to evaluate land-cover change on the Navajo and Hopi Reservations. Officials of the respective Tribal governments will use the information to develop ecosystem management plans that use historic and current data to support informed utilization of the resources. The effects of human impacts, grazing density, drought conditions, and range recoverability are critical to the analysis of these data. The study is identifying land-cover change on the Navajo and Hopi Indian lands over an extended period of time, using a variety of products derived from Landsat MSS and TM imagery to help evaluate these effects. A complete analysis of all products will document changes to the Native lands due to human impact, prolonged grazing, fluctuating precipitation levels, and their effects on range recoverability. The results of the study and evaluation of products will be presented to Tribal officials. Contact: Jana Ruhlman, 928-556-7111,jruhlman@usgs.gov 


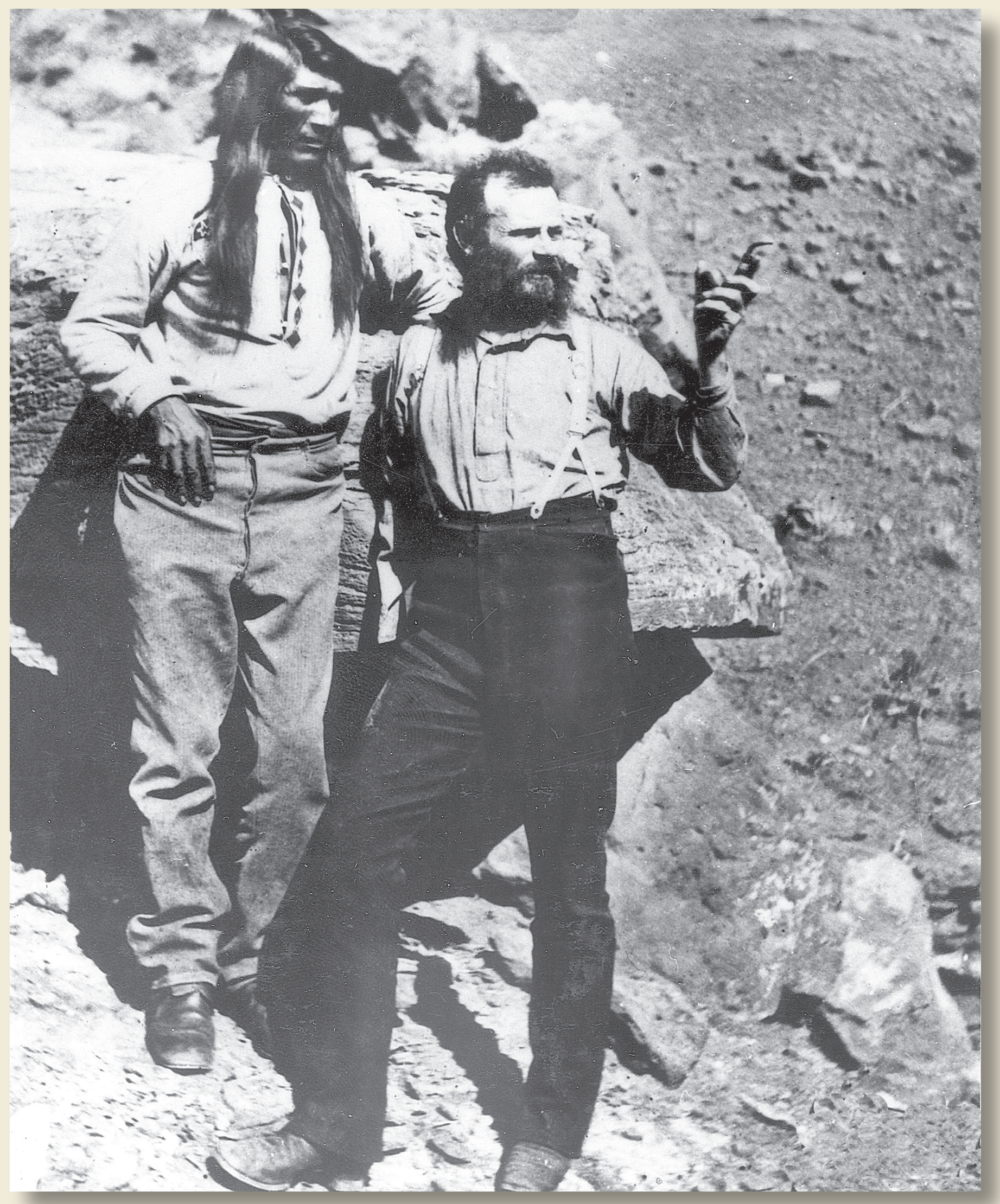

Tau-gu, a chief of the Paiute Indians, and Major John Wesley Powell, second Director of the U.S. Geological Survey, in southern Utah, about 1870. USGS Photographic Library; photographer unknown. 


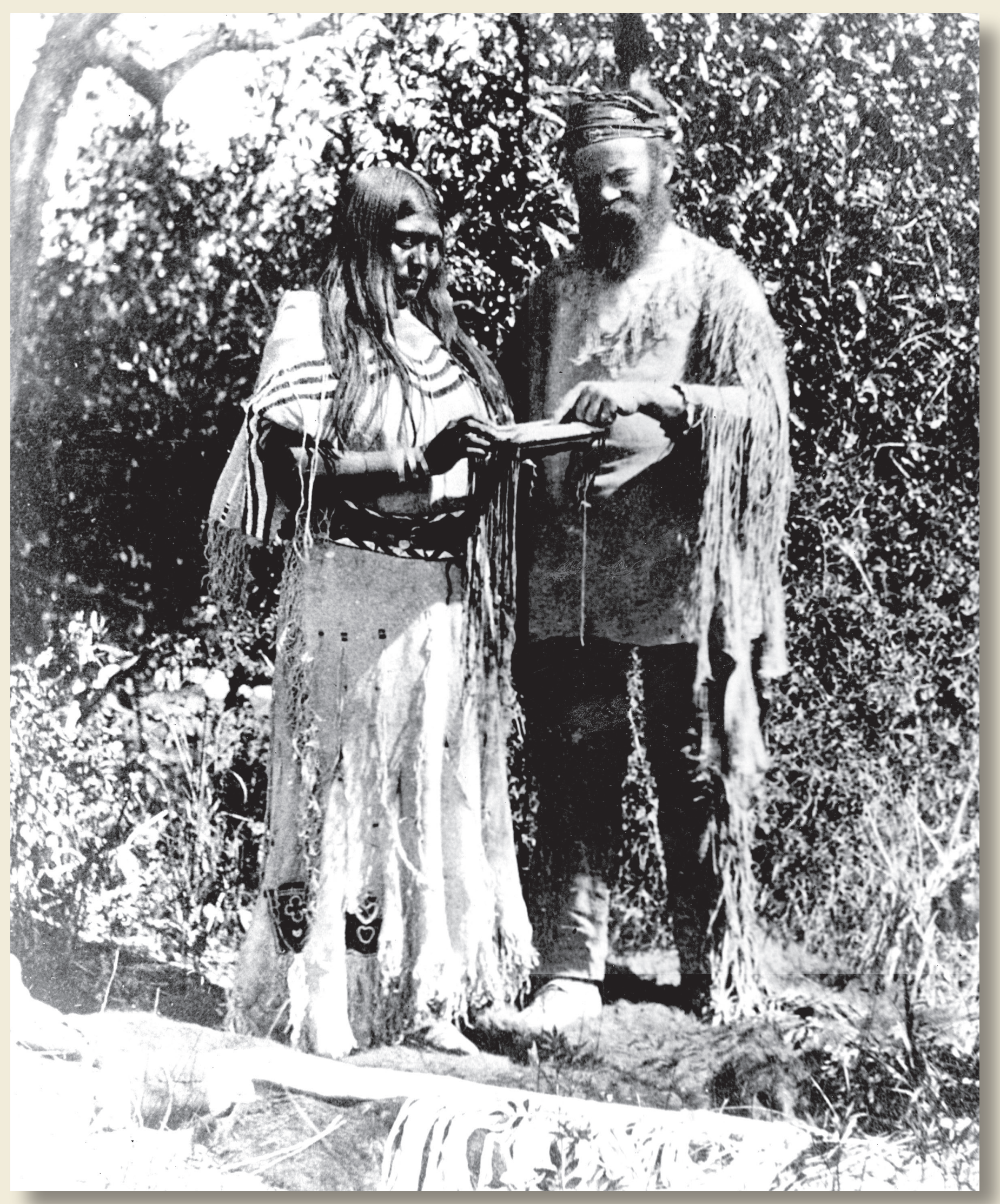

Tau-ruv, a member of the Paiute Indian Tribe, and Major John Wesley Powell. Photograph taken sometime during the 1870 s by J.K. Hillers. USGS and Smithsonian Institution photograph. 


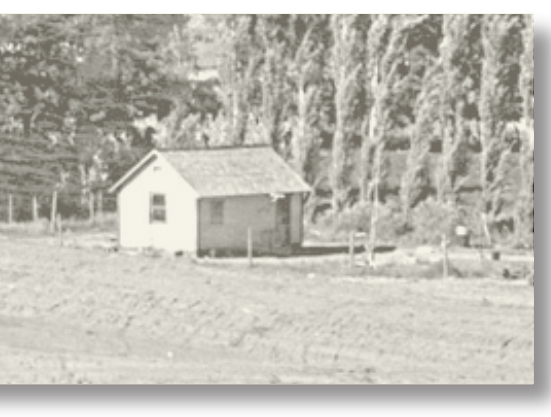

\section{Glen Canyon, Tribes, and the USGS (Arizona, Colorado, Utah)}

The Grand Canyon Monitoring and Research Center (GCMRC), within the USGS Southwest Biological Science Center, has a specific mission to provide science support to the Glen Canyon Dam Adaptive Management Program (GCD-AMP). The GCD-AMP is administered by the U.S. Bureau of Reclamation with guidance from a Federal Advisory Committee composed of representatives from six American Indian governments-Hopi Tribe, Hualapai Tribe, Kaibab Paiute Tribe, Navajo Nation, Paiute Indian Tribe of Utah, and Pueblo of Zuni-plus representatives from power, water, recreation, and conservation interests. The interests of the Paiute Indian Tribe of Utah are also represented in the program through the Kaibab Paiute Tribe. This stakeholder committee formulates recommendations to the Secretary of the Interior on science and management activities necessary to achieve the goals of the 1992 Grand Canyon Protection Act. The GCMRC then carries out the recommended science projects. The GCMRC works with all Native American Tribes in the GCD-AMP to accommodate traditional Native perspectives within the overall program. In FY 2004, the GCMRC continued agreements with four participating Tribes-Hopi, Hualapai, Kaibab Paiute Tribe, and Paiute Indian Tribe of Utah-to monitor the condition of terrestrial ecosystem resources in the Colorado River corridor that are of traditional importance to the Tribes. The GCMRC also established an agreement with the Hualapai Tribe in FY 2004 to provide part-time support for a Tribal technician to assist with hydrological gaging activities at the Diamond Creek gage on the Colorado River, adjoining the Hualapai Reservation. The GCMRC began planning an intertribal workshop to improve integration of traditional Native American perspectives in the GCMRC's ongoing science programs. The workshop was held in FY 2005 and was hosted by Northern Arizona University's Center for Sustainable Environments. Contact: Helen Fairley, 928-556-7285, hfairley@usgs.gov

\section{Hydrogeologic Study of the Upper and Middle Verde River Watershed (Arizona)}

The population of Yavapai County, Arizona, is growing rapidly, resulting in an increased demand on water resources in the upper and middle Verde River watershed. The watershed contains a thriving riparian zone and is the primary water supply for the county, as well as for large populations further downstream, including the Yavapai-Prescott Indian Tribe and the Fort McDowell Yavapai Nation. The hydrogeologic system in the watershed has not been comprehensively studied and the effects of historic and present development on regional water resources are poorly understood. Beginning in 2001, this study was funded by the Yavapai County Water Advisory Committee to improve hydrologic and geologic information upon which water resource decisions will be based. This effort used geophysical and geologic methods to better define the geometry of and internal structures in the basins and the composition and architecture of the basin fill. This study is augmenting a larger investigation supported by the State of Arizona. As part of both investigations, USGS personnel operate a microgravity network to measure changes in ground-water storage. Precipitation and streamflow data are being collected from new rain gages and a new stream gage on a tributary to Big Chino Wash. USGS scientists are collecting and analyzing ground-water samples to help delineate groundwater flow paths, and they are conducting surface resistivity surveys to delineate the thickness and extent of alluvial sediments in selected reaches of the Verde River. All of these investigations will produce data that can be directly used in a numerical hydrogeologic model of the system, providing critical information to water managers and users. The geology studies were completed in FY 2004. Contact: Victoria Langenheim, 650-329-5313, zulanger@usgs.gov or Kyle Blasch, 520-670-6671, ext. 283, kbalsch@usgs.gov 


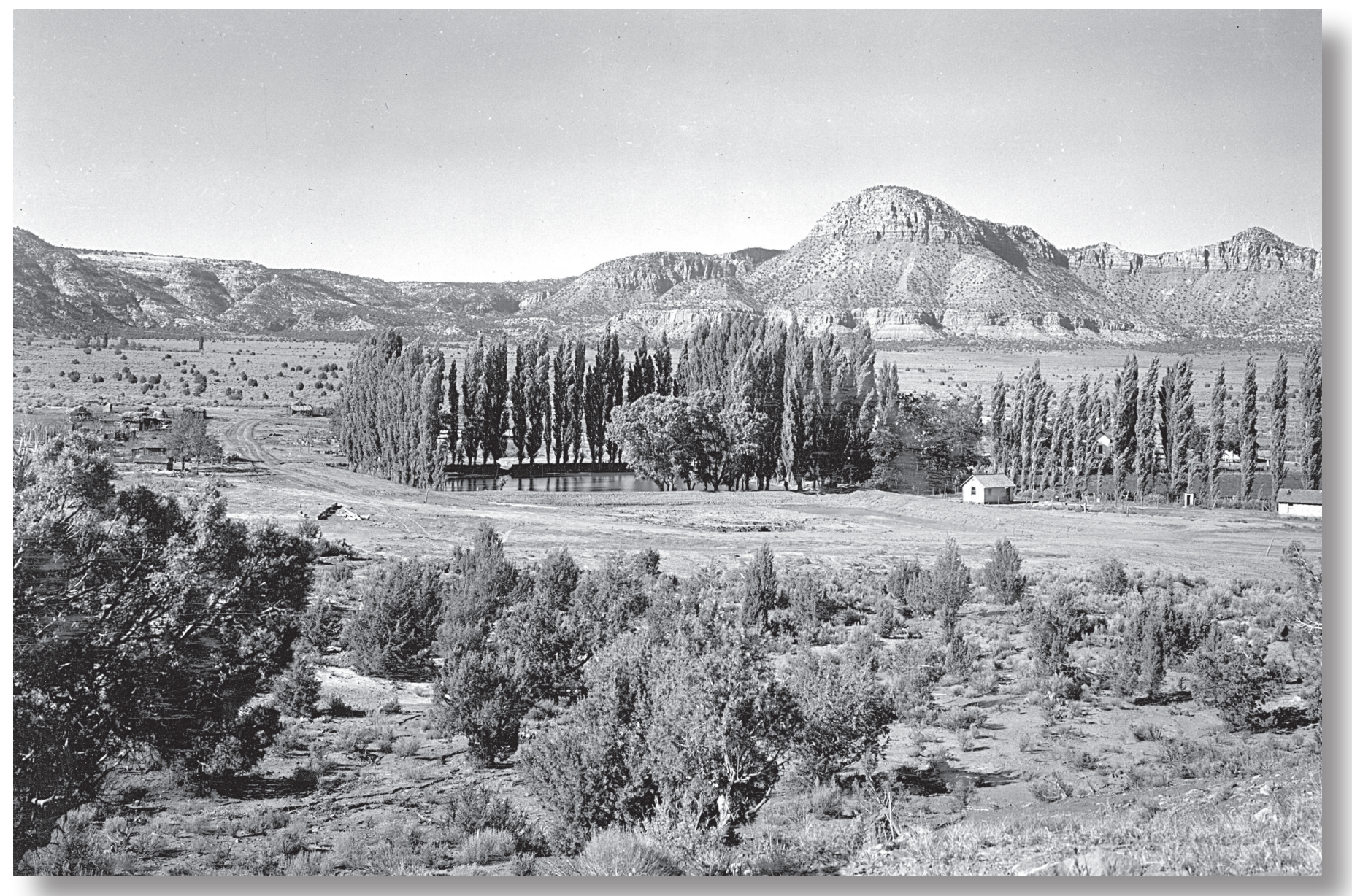

Kaibab Indian school near the town of Moccasin, northern Arizona, 1939. USGS Photographic Library; photograph by H.E. Gregory.

\section{Copper Mines and Ground Water (Arizona)}

Ground-water withdrawals associated with the first major copper mine proposed for Arizona since 1973 have the potential to affect existing water rights and water supplies of the area. At the request of the Secretary of the Interior, USGS hydrologists in Arizona worked with the U.S. Bureau of Land Management, U.S. Bureau of Indian Affairs, and other parties to develop a plan to monitor impacts to the ground-water system caused by mine-related pumping. The results could affect the claims to water by the Gila River Indian Community and the San Carlos Apache Tribe, for whom the Federal government has trust responsibilities. The USGS has begun playing a long-term role in the project by providing quality control on the hydrologic data collected as part of the ground-water monitoring plan. In FY 2004, USGS scientists began inventorying Phelps Dodge's monitoring wells in Safford, Arizona, as part of the USGS oversight of ground-water monitoring in the area. A prototype Web site has been developed and is being prepared to facilitate public access to the data. Contact: James G. Brown, 520-670-6671, ext.280,jgbrown@usgs.govor Bruce Gungle,520-670-6671 ext.233, bgungle@usgs.gov 


\section{Coeur d'Alene Tribe National Map Implementation and Wildfire Mitigation Application (Idaho)}

Coeur d'Alene employees are cooperating with USGS staff to improve the Tribe's wildfire management capabilities and to enhance the data available to all people involved in wildfire mitigation. USGS Western Region specialists in The National Map data integration and viewer implementation provided training to GIS experts at the Coeur d'Alene Tribe to implement The National Map over Tribal lands using data created by the Coeur d'Alene Tribe. Remote sensing experts from Central Region's EROS Data Center trained Tribal personnel in Landfire methodology for fire fuels modeling. The Tribe acquired LiDAR point data and high-resolution imagery for use in the project, and USGS purchased two copies of ERDAS Imagine image processing software for the Tribe to use as the project continues into 2005. Ultimately, Tribal personnel will be fully trained to apply the data in wildfire behavior models to predict and mitigate wildfire hazards. The resultant fire behavior model data will be served from the Tribe's Web site for use by other fire protection organizations in the area. The techniques can be transferred to other Tribes in the region in the future. Contact: Tracy Fuller, 208-387-1351,tfuller@usgs. gov or Eric Wood, 605-594-6068,woodec@ usgs.gov or Frank Roberts (Coeur d'Alene Tribe), 208-686-5307,fmroberts@cdatribe.org

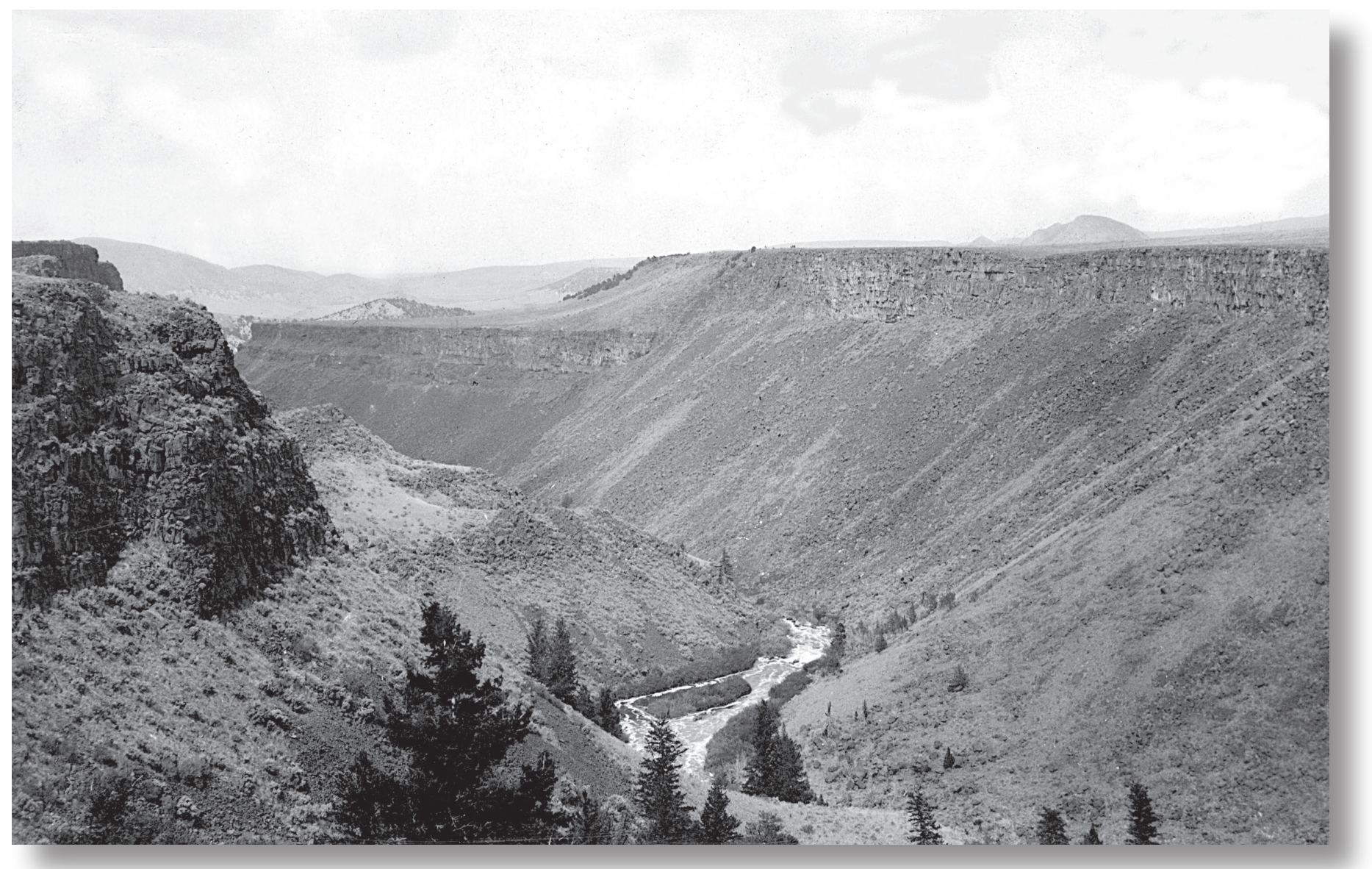

Canyon of the Blackfoot River along the north side of Fort Hall Indian Reservation, Bingham County, Idaho, August 30, 1913. USGS Photographic Library; photograph by G.R. Mansfield. 


\section{White Sturgeon Habitat Simulations to Assess the Feasibility of Enhancing Spawning Substrate in the Kootenai River (Idaho)}

In 1999, the USGS Idaho Water Resources District, in cooperation with the Kootenai Tribe of Idaho, began examining Kootenai River white sturgeon spawning habitat. Ultimately, the results of this project will be used by the Kootenai Tribe and others to evaluate the feasibility of various recovery actions on improving substrate conditions in Kootenai River white sturgeon spawning areas. The Kootenai River Sub-Basin is an international watershed that encompasses parts of British Columbia (Canada), Montana, and Idaho, making the river the second largest tributary to the Columbia River. During the last 80 years, the hydraulic, sediment transport, and substrate characteristics of the Kootenai River have been altered as a result of the construction and operation of Libby Dam, dike construction, and wetlands drainage, resulting in the decline of many resident fish populations including burbot and endangered Kootenai River white sturgeon. One limitation to white sturgeon spawning success may be the change from the natural fluctuations in flow and sedimentation in sturgeon spawning areas resulting from the operation of the dam. White sturgeon spawn at specific locations within the spawning reach. During September 2004, USGS scientists took 55 cores of the river substrate throughout the white sturgeon spawning reach. Cores are being tested by the Kootenai Tribe of Idaho for contaminants. Geologists described, sampled, and archived the core sediments, and the cores were photographed. Understanding the river bottom sediment from the cores in the spawning reach will lead to improved designs for enhancing the substrate of the sturgeon spawning habitat. In the past year, USGS scientists from the Idaho Water Science Center and from the Surface Water Modeling Research Center in Denver, Colorado, developed a detailed multidimensional computer model simulating river depth, streamflow velocity, shear stress, and sediment motion in the lower one-third of the white sturgeon spawning habitat. The model can simulate historic river flows as well as river management scenarios. The model is being used to identify geomorphologic and hydraulic features in the river, such as zones of streamflow velocity acceleration. The model also shows how riverbed elevations change over time, where riverbed sediments are scoured, and where sediments are deposited onto the riverbed under various streamflow conditions including the annual May-June sturgeon spawning season. These are factors that influence white sturgeon spawning patterns. This model will be used to design spawning habitat enhancement scenarios. The upstream boundary of the model is being extended upstream to include the entire white sturgeon spawning reach to allow testing of spawning habitat enhancement scenarios in the upstream part of the spawning reach. Bathymetric data for the model extension were collected by USGS personnel during August 2004. The new data permit detailed mapping of the river bottom topography. In cooperation with the Kootenai Tribe of Idaho, the USGS published Water Resources-Investigations Report 03-4324 and Open-File Report 2004-1045. Both reports are online at http://id.water.usgs.gov/public/reports.html. The studies and results have also been presented at numerous conferences. Sue Ireland of the Kootenai Tribe of Idaho has played a pivotal role in the success of this project. Contact: Gary Barton (USGS), 253-428-3600, ext. 2613, gbarton@usgs.gov or Sue Ireland (Kootenai Tribe of Idaho), 208-267-3620, ireland@kootenai.org

\section{Cui-ui in Pyramid Lake (Nevada)}

The cui-ui is an endangered fish of the sucker family that is found only in Pyramid Lake, Nevada. The Pyramid Lake Paiute Indians and other Northern Paiutes historically relied upon annual spawning runs of cui-ui for food. Cui-ui are also culturally important to the Pyramid Lake Paiutes. Since the Tribe controls use of Pyramid Lake and fully supports efforts to restore the cui-ui population, the Tribal Council has passed resolutions prohibiting harvest of cui-ui by non-Indians and Tribal members. The USGS is continuing studies of the population dynamics and reports results to the Tribal Chairman. Adult cui-ui are netted at the south end of Pyramid Lake in the spring and are marked to determine the mortality rate. Fish are recaptured in the fall at selected stations around the lake to determine juvenile population size and estimate mortality over the summer. Contact: Gary Scoppettone, 775-861-6390, gary_scoppettone@usgs.gov

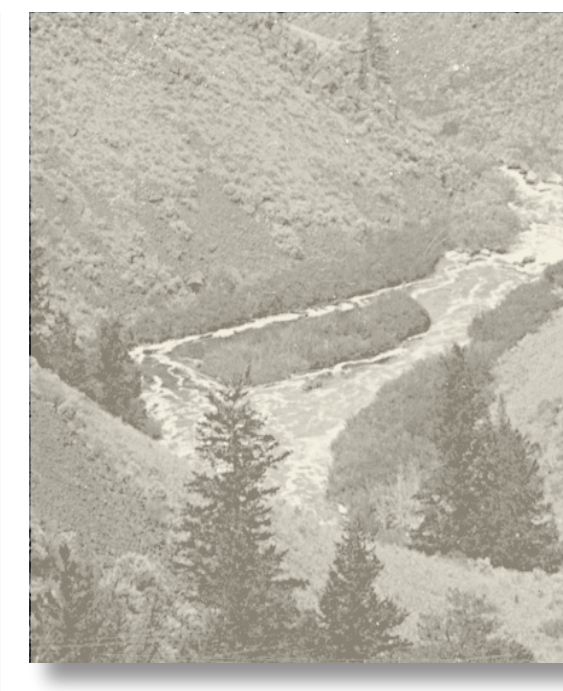




\section{Fallon Basalt Aquifer (Nevada)}

The Fallon Paiute Shoshone Tribe, the U.S. Navy, the U.S. Bureau of Reclamation, and the Nevada Division of Water Resources are cooperating with the USGS Nevada Water Resources District on a study to better define sources of water, controls on its use, and water quality of the Fallon Basalt Aquifer. This aquifer is the sole source of drinking water for the Fallon Paiute Shoshone Tribe, the City of Fallon, and the Fallon Naval Air Station. All parties are concerned about the quality and availability of the water resource. The Fallon Tribe is contributing data and funding to the project and is providing access to Tribal lands for this study. A USGS report summarizing work on potential geochemical reactions from injection of surface water into the basalt aquifer is being prepared. A USGS study to determine the potential for formation of chlorination by-products from injection of treated surface water into the basalt aquifer was completed. A summary of the results of a USGS study of chlorination by-products is also being prepared. In addition, a continuing study is characterizing the basalt aquifer by drilling deep test holes into the aquifer. Four holes have been drilled, with the final, fifth hole to be completed once sufficient funding is obtained from either the U.S. Bureau of Reclamation or the Fallon Naval Air Station. Available data will be compiled in a USGS report summarizing the deep test drilling. Remaining work includes developing a numerical ground-water flow model and a final report. Contact: Douglas Maurer, 775-887-7631,dkmaurer@usgs.gov

\section{Hydrologic Information for the Walker River Paiute Tribe (Nevada)}

A study was begun in FY 2004 to quantify the volume of natural streamflow in the Walker Basin and to determine evapotranspiration losses from natural riparian vegetation and the surface of Walker Lake. Other parts of this project include developing an improved water budget for Walker Lake and developing the capability to predict how changes in irrigation practices in and below Mason Valley will affect flows in the lower Walker River. Although this study is funded by the U.S. Bureau of Reclamation, access to the Walker River Paiute Tribal lands is an important factor in this study. A Memorandum of Understanding was signed between the Tribe and the USGS in August 2004 to allow water-quality and water-level measurements in existing wells and drilling of new wells, establishment of an evapotranspiration monitoring site, and measurement of streamflow at various locations on Tribal lands. These data, in addition to other data collected throughout the basin, will be used to help develop a computer model to predict consequences of management decisions. Contact: Tom Lopes, 775-887-7688, tjlopes@usgs.gov

\section{Bacterial Cold-Water Disease Research (Washington, Oregon)}

During the past year, staff of the Northwest Indian Fisheries Commission have led the formation of a Bacterial Cold Water Disease Research Group, composed of fish-health professionals from Tribal, Federal, State, and academic entities in the Pacific Northwest. The purpose of the group is to improve knowledge of the epidemiology of Bacterial Cold Water Disease (BCWD) and to facilitate development of novel approaches for the prevention and control of this serious disease that affects both wild and hatchery fish stocks. Losses from BCWD at Tribal hatcheries in the Pacific Northwest can be much more severe than from other well-known fish diseases including Bacterial Kidney Disease or Whirling Disease. Current prevention and control strategies are mostly dependent upon timely applications of approved drugs and improving the rearing environment for the fish. However, both strategies have produced inconsistent results. Drugs that are more effective and a better understanding of the rearing strategies that reduce the impacts of this disease are needed. Scientists at the USGS Western Fisheries Research Center have hosted the working group meetings and have begun to develop quantitative diagnostic assays for the causative agent, Flavobacterium psychrophilum. Such work will be useful for determining how BCWD is transferred from adult to fry. Contact: Lyman Thorsteinson, 206-526-6282, lyman_thorsteinson@usgs.gov 


\section{Transport and Fate of Bacteria and Nitrate in Ground Water, Lower Nooksack River Basin (Washington)}

The Nooksack Indian Tribe wants to improve its understanding of the fate and transport of fecal coliform and nitrate contaminants as the contaminants move from agricultural fields to the ground-water system and eventually to surface-water systems in the lower Nooksack River Basin. Additional information about the extent of denitrification is also needed to provide realistic constraints on water-quality models that are used to make water-resource management decisions. In FY 2002, scientists with the USGS Washington Water Science Center began studying the interaction between surface and ground water in the shallow aquifer of the lower Nooksack River Basin. Stream locations where ground- and surface-water exchanges occur were identified. A network of stations was used intermittently during FY 2003 to monitor the hydraulic gradient between ground water and surface water. Ground water and surface water have been sampled and analyzed for concentrations of $E$. coli bacteria, a suite of nutrients, and other constituents related to ground-water denitrification. A laboratory microcosm experiment was conducted to evaluate the attenuation rate of $E$. coli in stream sediments from Fishtrap Creek. Ground- and surface-water samples were collected and analyzed during FY 2004. The data were interpreted and were published in an interpretive report during FY 2005 (USGS Scientific Investigations Report 2005-5255, "Ground water/surface water interactions and quality of discharging ground water in streams of the Lower Nooksack River basin, Whatcom County, Washington," by Stephen E. Cox, F. William Simonds, Llyn Doremus, Raegan L. Huffman, and Rose M. Defawe). Contact: Steve Cox, 253-428-3600 ext.2623, secox@usgs.gov

\section{Shallow and Airborne Trace-Metal Concentrations from Lake Roosevelt (Washington)}

Lake Roosevelt is a 125-mile-long reservoir in eastern Washington State that extends from Grand Coulee Dam to near the Canadian border where the Columbia River is free flowing. The reservoir is also a cultural and economic resource for the Confederated Tribes of the Colville Reservation. Mining waste and other upstream activities have contaminated the lake, leading to concerns about the contamination effects on human health. The Colville Tribes want to know more about the potential threat to human health of the trace metals in exposed nearshore sediment of Lake Roosevelt. During periods when the water level of the reservoir is lowered, large areas of contaminated sediment are exposed. Upon drying, the fine-grained portion of the sediment, including trace metals, becomes airborne due to high winds and can be inhaled by area residents and visitors. USGS Washington Water Science Center scientists have studied two different, though related, aspects of the potential human health issues involving trace metals in fine-grained sediment: the sediment itself, prior to disturbance, and the airborne characteristics of the sediment. Sediment samples were collected to determine the concentrations of trace metals in the fine-grained sediment exposed during the spring 2001 drawdown. The results of the sediment study were published in USGS Water Resources Investigations Report 2003-4170 entitled, "Concentrations and distribution of slag-related trace elements and mercury in finegrained beach and bed sediments of Lake Roosevelt, Washington, April-May, 2001," by Majewski and others. Once airborne, the dust particles can be carried downwind various distances depending on their size and the magnitude and duration of the prevailing winds throughout the Lake Roosevelt airshed. From FY 2002 through FY 2004, USGS scientists monitored air quality at several locations along Lake Roosevelt to determine the occurrence, concentrations, distribution, and seasonal variability of selected trace elements on airborne dust particles and, to the extent possible, the fraction of airborne trace-elements originating from exposed lake-bed sediment. This work is expected to continue through FY 2006. Contact: Sue Kahle, 253-4283600,ext.2616,sckahle@usgs.gov 


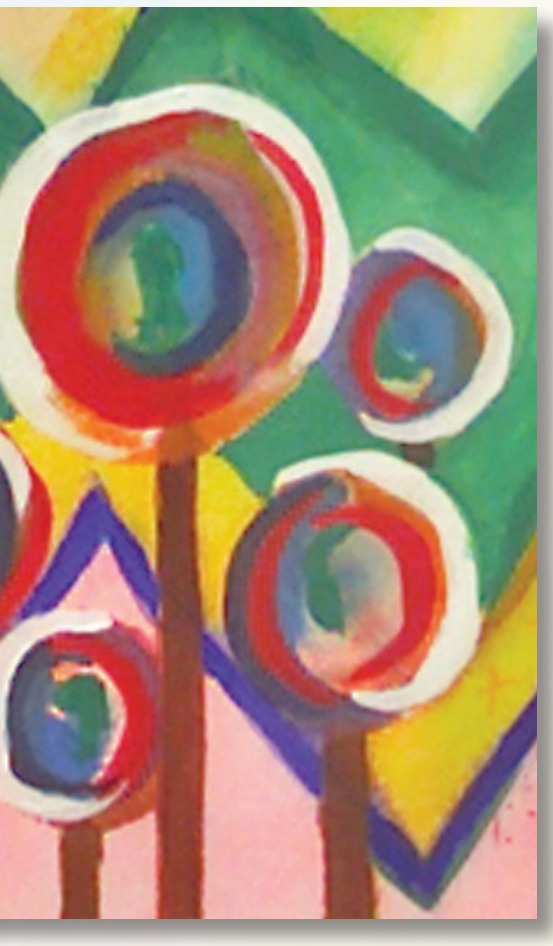

\section{Trace-Elements Effects on Water Quality and Biological Health, Lake Roosevelt National Recreational Area (Washington)}

Mining waste and other upstream activities have introduced large quantities of metals into Lake Roosevelt, causing concerns about the effects of the products of these activities on fisheries resources. This project, started in FY 2003 in coordination with the National Park Service, included sampling and analyzing sediments from eight sites on Lake Roosevelt for concentrations of metals, as well as biological toxicity, bioaccumulation potential, and geochemistry. The results will help characterize the environmental processes resulting in the uptake of metals to the water and biota in the lake. Because Lake Roosevelt is a cultural and economic resource for the Confederated Tribes of the Colville Reservation and Spokane Tribe of Indians, the USGS coordinated the selection of sites with the Tribal Historical Preservation Officers (THPO) of both Tribes and with the National Park Service (NPS) archeologists. Upon request of the Colville Tribe's THPO, the sediment collection at three sites was monitored by a NPS archeologist. Consultation with the Spokane Tribe's THPO resulted in no additional action needed to conduct the sampling. The results of the study are being prepared for publication. Contact: Tony Paulson, 253-428-3600 ext.2681, apaulson@usgs.gov

\section{Trace-Element Concentrations in Sediment Cores and Rates of Sediment Accumulation in Lake Roosevelt (Washington)}

Lake Roosevelt is a cultural and economic resource for the Confederated Tribes of the Colville Reservation. Mining waste and other upstream activities have contaminated the lake, leading to concerns about the contamination effects on human health. Other aspects of the contamination have been studied, but very little is known about trace-element concentrations in the sediment accumulated within the reservoir since it was built. Information is also lacking about the presence and distribution of smelter-produced slag particles in the middle and lower reaches of Lake Roosevelt. In FY 2002, USGS scientists began a study in cooperation with the Colville Tribes to gather and analyze data to better understand the three-dimensional extent of trace-element contamination of the bed sediment of Lake Roosevelt. Six deep sediment cores were collected from the mid-channel of slack-water sections of the reservoir. During FY 2003, selected intervals from the cores were analyzed for concentrations of selected trace elements, including arsenic, cadmium, copper, lead, mercury, and zinc. The samples were also age-dated. Slag particles identified in some of the core samples have been examined with a scanning electron microscope and a dispersive X-ray spectrometer. Sampling results were analyzed in FY 2004 and a report was published in FY 2005 (USGS Scientific Investigations Report 20045090, "Vertical distribution of trace-element concentrations and occurrence of metallurgical slag particles in accumulated bed sediments of Lake Roosevelt, Washington, September 2002," by S.E. Cox, P.B. Bell, J.S. Lowther, and P.C. VanMetre). Contact: Steve Cox, 253-428-3600 ext.2623,secox@usgs.gov

\section{White Sturgeon Restoration in the Columbia River (Washington)}

USGS fishery biologists are participating with the Spokane Tribe of Indians, the Confederated Tribes of the Colville Reservation, and Columbia River Inter-Tribal Fish Commission fishery biologists in an effort to restore declining white sturgeon populations in the Columbia River basin. Restoration of this species is especially important because of the cultural significance of these fish. Federal scientists and Tribal representatives continue working together on the Upper Columbia River White Sturgeon Recovery Team and collaborate on research projects funded by the Bonneville Power Administration. Contact: Mike Parsley, 509-538-2299, ext. 247, michael_parsley@usgs.gov

(Facing Page) "Mountains and circles" artwork by Regina One Star, Sicangu (Rosebud) Lakota. 


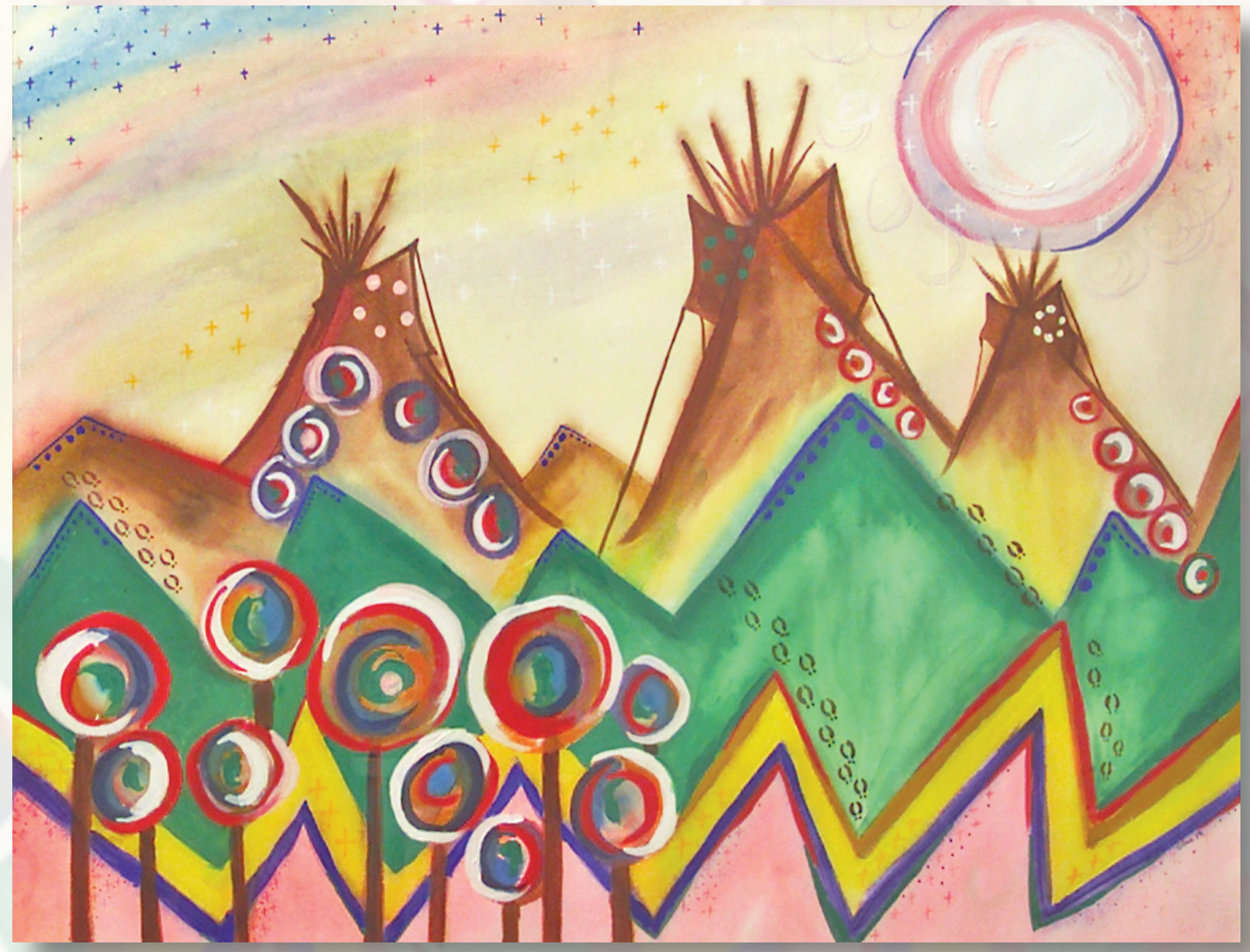




\section{Ground-Water Resources of the Yakima River Basin (Washington)}

Surface water in the Yakima River basin is being adjudicated. The amount of surface water available for appropriation is not known, but there are increasing demands for water for municipal, fisheries, agricultural, industrial, and recreational uses. These demands must be met by either ground-water withdrawals or by changes in the way water resources are allocated and used. Ongoing management of water in the basin also may be affected by rules to protect salmonid fish under the Endangered Species Act. In FY 2000, the USGS began a study of the ground-water system in the basin, in cooperation with the U.S. Bureau of Reclamation and the Washington State Department of Ecology, and working with the Confederated Tribes and Bands of the Yakama Nation. Results of the study will describe the geologic framework and ground-water flow system in the Yakima River basin as well as the interaction between ground water and surface water. A ground-water model will be constructed to improve understanding of the system and to help estimate the effects of selected management strategies. The model will address the effects of potential future ground-water pumping on streamflow because of the importance of streamflow to the life-history stages of salmonids. As part of this project, about 2,000 wells were visited to verify locations and measure water levels. Water levels were measured six times at about 800 of these wells. Information about all inventoried wells was added to the USGS National Water Information System. Lithologic information from each inventoried well is being used to construct maps of the hydrogeologic units. By the end of FY 2004, hydrogeologic units were mapped for four of the six sedimentary basins. The interaction of ground water and surface water along selected reaches was monitored by collecting continuous water-level and temperature data. Analysis of these data is ongoing. Historical municipal ground-water withdrawal data have been collected, compiled, and extrapolated back in time. Agricultural ground-water withdrawal data were collected in FY 2002 and FY 2003 , and the data are being analyzed. Another part of the ground-water withdrawal study involves relating ground-water rights to specific wells. Of about 2,800 water rights, well logs were matched with about 2,600. Ground-water recharge was estimated for the upland, forested areas in the basin using four previously constructed watershed models, and datasets are being compiled to estimate recharge in the low-lying agricultural areas. The model used to estimate recharge in the low-lying areas (called the Deep Percolation Model) was re-coded into a USGS modeling system and a report describing the model was written. New methods were developed to thermally profile long river reaches to locate areas of large ground-water contributions and to identify potential areas of good salmonid habitat. About 120 miles of river have been profiled. Contact: John Vaccaro, 253-428-3600 ext.2620,jvaccaro@usgs.gov

\section{Restoration Monitoring of Satus Creek and the Satus Wildlife Area, Yakama Nation Reservation (Washington)}

Agricultural return flows are known to contribute suspended sediment, nutrients, bacteria, metals, and pesticide loads to creeks and rivers in the Yakima River basin. In particular, Satus Creek, located on lands of the Confederated Tribes and Bands of the Yakama Nation, receives loads from the North Drain return flow, resulting in increases of sediment, nutrients, bacteria, and pesticides, both in the water column and in streambed sediments. In addition, the deposition of sediment from the North Drain return flow has created barriers to the migration of fish protected under the Endangered Species Act (ESA). A large-scale restoration effort by the Yakama Nation and the U.S. Army Corps of Engineers (ACE) is being conducted to improve the aquatic ecosystem associated with Satus Creek and the Satus Wildlife Area. Several salmonids that are listed under the ESA have historically used Satus Creek for parts of their lives. In the Yakima River basin, a large part of the production of one of these species (anadromous steelhead trout) occurs in Satus Creek. The Satus Wildlife Area also is an important component in the restoration of habitat for wildlife and fish in the lower Yakima River basin. The USGS, with funding from the ACE, monitored the hydrologic, water-quality, and past biologic effects on warm-water fish in the area of the North Satus Drain Ecosystem Restoration to identify temporal and spatial changes in the system. The USGS also compiled selected historical data for Satus Creek, North Drain, and the local shallow ground-water system. The USGS began monitoring the current baseline conditions in FY 2002 and continued monitoring conditions until mid-FY 2004. The USGS project and the ACE restoration was suspended due to ACE funding limitations. The ACE plans to start the engineering part of the project in FY 2006. As of FY 2004, data were collected at various surface-water and ground-water sites to identify pre-restoration concentrations of nutrients, metals, and organochlorine compounds. Fish tissue samples from carp in the Satus Wildlife Refuge and bed-sediment samples at two sites were also collected and analyzed for metals and organochlorine compounds. The fish samples had large concentrations of PCBs and DDT compounds. Although the bed-sediment samples showed the presence of certain metals and organochlorine compounds, the concentrations were low enough to allow for the construction and movement of sediment without harm to the local environment.

Contact: John Vaccaro, 253-428-3600 ext. 2620,jvaccaro@usgs.gov 


\section{Yakima River Basin Stream Quality and Biological Communities (Washington)}

The lands of the Confederated Tribes and Bands of the Yakama Nation encompass more than 100,000 acres of intensively irrigated land within the Yakima River basin. Agricultural runoff throughout the Yakima basin, including the Yakama Nation, continues to be assessed as part of a National Water Quality Assessment Program (NAWQA) conducted by the USGS Oregon and Washington Water Science Centers. Trends are being assessed by comparing water-quality data (legacy pesticides, trace elements, fecal indicator bacteria, aquatic communities of insects and algae) to similar data collected more than a decade ago in an earlier NAWQA study. The study of agricultural runoff from small watersheds includes several drainages within the Yakama Nation. NAWQA program personnel worked cooperatively with personnel from the Yakama Nation's Department of Natural Resources. Agricultural runoff was collected from a network of biological sampling sites on several small watersheds to assess the effect of different irrigation methods and agricultural practices on surface-water quality, including algae and aquatic insects and their habitats. The intent of the biological assessment is to determine a threshold of agricultural activity capable of sustaining healthy aquatic communities. In addition, a ground-water sample and a surface-water sample were collected within the basin to measure emerging contaminants, including antibiotics, other prescription and non-prescription drugs, organic-waste-water contaminants, and steroids. These chemicals may be leaching to shallow ground water from combined animal-feeding operations or may be entering surface water from point and non-point sources. During FY 2003 and FY 2004, weekly water samples were taken and analyzed from a series of wells and surface-water sites to provide data upon which to base a three-dimensional understanding of the transport of anthropogenic compounds through an agricultural system. This is one part of a national study by NAWQA (http:// wa.water.usgs.gov/projects/ccyk/). Additional reports from studies of agricultural contaminants in the Yakima basin, as well as chemical data, can be obtained at http://oregon.usgs.gov/projs_ dir/yakima/index.html. Contact: Robert W. Black, 253-428-300, ext.2687, rwblack@usgs.gov or Greg Fuhrer, 503-251-3231,gjfuhrer@usgs.gov

\section{Watershed Restoration for Reintroduction of Salmon and Steelhead (Washington)}

USGS fishery biologists are continuing a partnership with the Confederated Tribes and Bands of the Yakama Indian Nation fishery biologists in an effort to assess and restore the Rattlesnake Creek watershed of the White Salmon River basin. Restoration of this watershed is important because of the possible reintroduction of salmon and steelhead above Condit Dam on the White Salmon River. Federal scientists and Tribal representatives worked together on a Technical Advisory Committee to the White Salmon Watershed Management Council. For more information about this project, see the following Web site: http://wfrc.usgs.gov/research/ fish\%20populations/STPetersen2.htm Contact: Pat Connolly, 509-538-2299, ext. 269, patrick_connolly@usgs.gov

\section{Modeling Historical, Current, and Potential Fish Productivity of the White Salmon River Watershed (Washington)}

USGS fishery biologists from the Western Fisheries Research Center's Columbia River Research Laboratory cooperated with fishery biologists from the Confederated Tribes and Bands of the Yakama Nation to characterize fish production in the White Salmon River in southwest Washington. The Ecosystem Diagnosis and Treatment (EDT) model was used to model historical, current, and potential productivity of important anadromous species of Chinook, coho, and steelhead. The information will serve to help managers prioritize stream restoration efforts. Products of the cooperative work include a report and extensive contributions to a region-wide subbasin planning effort. Contact: Patrick Connolly, 509-538-2299, ext. 269,patrick_connolly@usgs.gov 



\section{Water Management and Steelhead on National Wildlife Refuges (Washington)}

USGS fishery biologists from the Western Fisheries Research Center are continuing to study the effects of water and land management at Toppenish National Wildlife Refuge (managed by the U.S. Fish and Wildlife Service). Fishery biologists of the Confederated Tribes and Bands of the Yakama Nation are cooperating in this study. The study involves estimating the number of steelhead that enter the refuge, their residence times, and their condition and growth rate. The Toppenish National Wildlife Refuge is adjacent to the Yakama Indian Reservation in southern Washington. Information will help refuge managers make decisions about managing water movement, constructing or removing dikes, and altering vegetation types. A USGS Web site for the project is: http://wfrc.usgs.gov/research/aquatic\%20ecology/STPetersen13.htm Contact: Jim Petersen, 509-538-2299, ext. 236, jim_petersen@usgs.gov

\section{Water Resources of the Tulalip Tribes (Washington)}

Future increases in population and development of lands of the Tulalip Tribes and neighboring areas would lead to increased pumping of ground water both on and off the Native lands. Increased pumpage may decrease base flows of streams and could affect fish-rearing operations in the Tulalip and Mission Creek watersheds. In cooperation with the Tulalip Tribes, USGS scientists evaluated Tribal ground-water and surface-water resources. As part of the study, 252 wells were inventoried and 15 wells were sampled. Selected streams and wells were monitored for flows and water levels, respectively. The geohydrologic system was mapped and a water budget and future ground-water use were evaluated. The results of the study were published in FY 2004 in "Water Resources of the Tulalip Indian Reservation and Adjacent Area, Snohomish County, Washington, 2001-03" (U.S. Geological Survey Scientific Investigations Report 20045166, http://water.usgs.gov/pubs/sir/2004/5166/). Contact: Lonna Frans, 253-428-3600 ext. 2694,lmfrans@usgs

\section{Estuaries Role in Maintaining Chinook Salmon Populations (Washington)}

USGS fishery biologists are collaborating with the Skagit River System Tribal Cooperative and with the Nisqually Tribe in a study to evaluate the importance of tidal delta habitat for juvenile Chinook salmon in the Skagit and Nisqually Rivers. Tribal fishery biologists seine and trap juvenile salmon and collect samples of fish for further study. USGS fishery biologists process the otoliths (ear bones) from the samples to determine length of residence and growth of the juvenile salmon in the tidal delta habitat. The study is funded by Seattle City Light, Skagit System Cooperative, and the USGS. Contact: Lyman Thorsteinson, 206-526-6282, lyman_thorsteinson@usgs.gov

(Facing Page) Historical image courtesy of the Blue Cloud Abbey at Marvin, South Dakota.

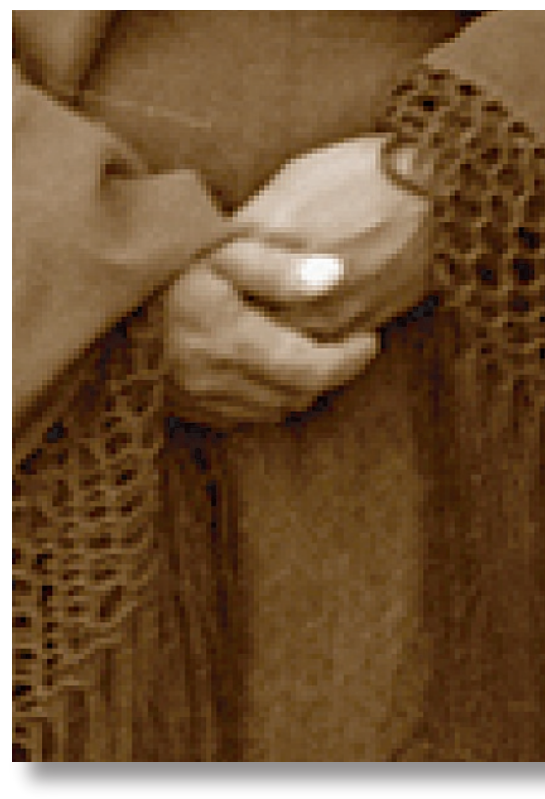




\section{Trends in Streamflow in the Lower Puyallup River Basin (Washington)}

The Puyallup Tribe of Indians is interested in improving their understanding of the water resources of the lower Puyallup River basin to ensure sufficient water to meet Tribal and fish hatchery needs and for future water-resource decisions. The USGS, in cooperation with the Puyallup Tribe, conducted a study to identify trends in streamflow in the lower Puyallup River basin and to compare streamflows in the Puyallup River with regulatory minimum instream flows. Results of the study were published in FY 2004 ("Trends in streamflow and comparisons to instream flows in the lower Puyallup River basin, Washington," U.S. Geological Survey Scientific Investigations Report 2004-5016, http://water.usgs.gov/pubs/sir/2004/5016/). Findings indicate a lack of statistically significant trends in any of the streamflow measures analyzed for the years 1980 through 2001. Two years of data that were analyzed in detail (1991 and 1992) showed that for significant parts of those years, unit (15-minute interval), daily mean, and daily minimum streamflow values were below regulatory instream flows. Furthermore, the fraction of time below the regulatory flows varied depending on the streamflow statistic used. The unitstreamflow hydrograph for the Puyallup River at Puyallup exhibits a distinct, regular pattern. The hydrograph closely mimics the hydrograph at Lake Tapps Diversion, on the White River, a tributary of the Puyallup River, which is the outflow from a power plant, suggesting that the power-plant outflow affects streamflow in the Puyallup River. Streamflow entering Lake Tapps through the White River Canal does not exhibit the same pattern as the Puyallup River or Lake Tapps Diversion. The influence of the White River Canal on streamflow in the Puyallup River appears to be obscured by operation of the Lake Tapps Diversion. Contact: Steve Sumioka, 253-428-3600, ext.2645, ssumioka@usgs.gov

\section{Geomorphic Mapping of the Dosewallips River (Washington)}

The USGS Washington Water Science Center is cooperating with scientists of the Port Gamble S'Klallam Tribe to map areas where habitat restoration activities could provide the greatest improvements for fish that are listed under the Endangered Species Act. The Dosewallips River, to the west of Hood Canal in Washington, is one of the streams least impacted by human activities, although historical logging activities and some development have significantly changed the river's ability to support fisheries. Remote sensing data-LIDAR (high resolution, highly accurate elevation data) and digital color orthophotography_are being used to identify overflow channels, abandoned stream channels, and flood-plain shelves near the river elevation where restoration activities may turn them into high-quality salmon habitat. Elevation maps, slope maps, and digital color imagery are incorporated into a Geographic Information System and then interpreted using multiple lines of supporting evidence, and supported by field reconnaissance. As large woody debris naturally returns to the stream, or is placed as part of a restoration plan, these near-stream channels and shelves will provide salmon spawning and rearing habitat. Contact: Joseph L. Jones, 253-428-3600,ext.2684,jljones@usgs.gov

\section{Elwha Sediment Transport Model of Suspended Sediment and Effect on Aquatic Habitat in Elwha River (Washington)}

The USGS Washington Water Science Center is modeling fluvial sediment transport in the Elwha River to help management agencies understand the potential changes in hydrology and sediment transport in response to dam removal. A sediment-transport model has been constructed to examine the response of suspended-sediment concentrations and the different sizes of streambed material to different streamflow scenarios. The results will provide information about the potential effects of dam removal on resources of Lower Elwha Klallam Tribe, including (1) salmon habitat, (2) flooding of Tribal lands, and (3) the recovery of the river after dam removal. Contact: Chris Konrad, 253-428 3600, ext.2634, cpkonrad@usgs.gov 


\section{Coastal Cutthroat Trout Distribution in Columbia River Gorge (Washington, Oregon)}

USGS fishery biologists from the Western Fisheries Research Center's Columbia River Research laboratory cooperated with fishery biologists from the Confederated Tribes and Bands of the Yakama Nation and the Confederated Tribes of the Warm Springs Reservation to describe current distribution of coastal cutthroat trout in stream systems draining to the Columbia River within the Columbia River Gorge. Other cooperators include the Oregon Department of Fish and Wildlife, Washington Department of Fish and Wildlife, and U.S. Fish and Wildlife Service. Poor hatchery returns, low angling success, and low numbers of fish at counting stations indicate that populations of sea-run cutthroat trout have declined throughout the lower Columbia River basin. Information on the current status of sea-run and resident coastal cutthroat trout populations in the lower Columbia River, especially above Bonneville Dam, is extremely limited. This effort provides a first step toward assessing needs for specific management and recovery goals for coastal cutthroat trout in the Columbia River basin above Bonneville Dam. Products of the cooperative work include a report (http://www.efw.bpa.gov/Publications/ Z00005678-A.pdf) and a Web site (http://ocid.nacse.org/nbii/cutbib/index.php) that provide information and species distribution of the coastal cutthroat trout. Results of this effort were presented at the American Fisheries Society's Western Division conference (Salt Lake City, Utah; February 2004). The project will continue when funds are available. Contact: Patrick Connolly, 509-538-2299, ext.269, Patrick_Connolly@usgs.gov

\section{Umatilla-USGS Cooperative Research on Pacific Lampreys (Oregon)}

The Pacific lamprey (Lampetra tridentata) is an ancient fish, with no jaws, no bones, no true fins, and no scales. The lamprey has declined in abundance and become locally extinct. Recent USGS research describes how stream habitat characteristics influence the distribution and abundance of the larval form of lamprey in the upper John Day River in northeastern Oregon. The findings emphasize the need to consider spatial relations, both in examining larval lamprey habitat relationships and in developing conservation plans for declining lamprey populations. Often streams are managed or studied in sections that have meaning to people, such as pools, riffles, and distances between landmarks, but we need to realize that fish may respond to habitat features at a variety of scales that have meaning to their survival, reproduction, and migration. These spatial scales may be larger or smaller than ones meaningful to people. This research was conducted in partnership with the Confederated Tribes of the Umatilla Indian Reservation, with organizational leadership and science support from a Umatilla research biologist. Indian tribes in the Columbia basin and coastal regions of the Pacific Northwest value Pacific lamprey for their cultural significance and importance as a food source. The research showed that stream habitat characteristics predicted patterns in larval lamprey abundance although the effects of the characteristics varied, depending on the length of stream being considered. The distribution of larvae over an entire 34-mile section of stream was associated with deep-water reaches in low-gradient areas where overhead cover from riparian vegetation was limited. In contrast, patchiness in occurrence of lamprey larvae within a 150 -foot sampling site was associated with low water velocity, the shape of the stream channel, and the availability of sand and silt suitable for burrowing. Other factors, such as distance upstream along the river and sample location within the channel, explained additional variation in larval abundance. Contact: Christian Torgersen, 541-758-7797, ctorgersen@usgs.gov or David Close (Umatilla), 517-432-1141,closedav@msu.edu 


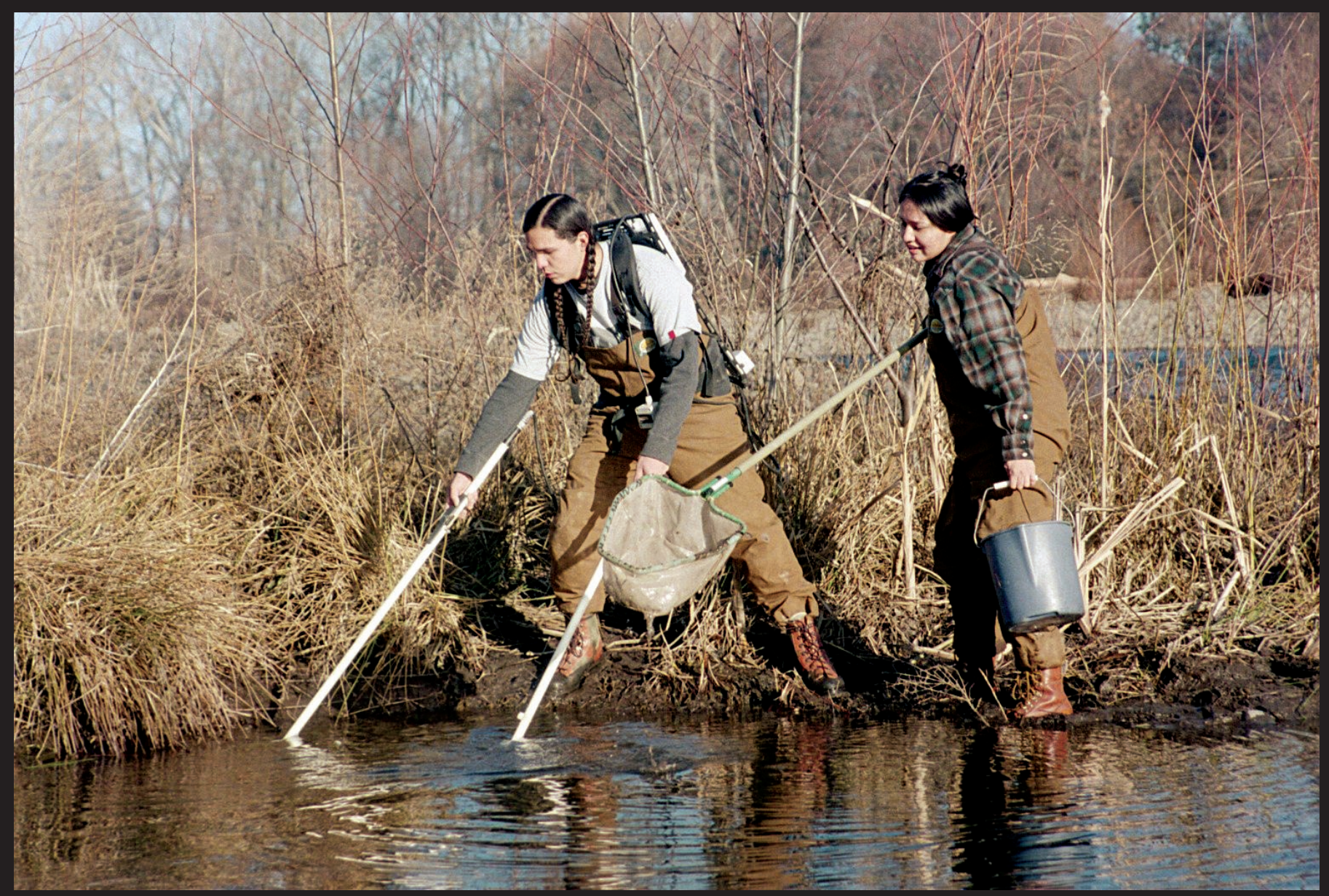

Andrew Wildbill and Donna Nez, members of the Confederated Tribes of the Umatilla Indian Reservation, assisting with larval lamprey sampling. Photograph by Will Phinney, Confederated Tribes of the Umatilla Indian Reservation.

\section{Pacific Lamprey Research on the Willamette River (Oregon)}

The USGS is assisting Columbia River Treaty Tribes in their effort to study the status and needs of Pacific lamprey in the Columbia River basin. USGS biologists from the Western Fisheries Research Center are cooperating with the Columbia River Inter-Tribal Fish Commission (CRITFC) to determine how lampreys migrate past a dam on the Willamette River near Portland, Oregon. Biologists from the USGS and CRITFC will combine resources to implant lampreys with radio transmitters and track them as they move around and past the dam. Knowing how the fish move in relation to the dam can be used to improve the fish passage system on the dam to increase lamprey passage. Contact: Matthew Mesa, 509-538-2299 ext. 246, matt_mesa@usgs.gov 


\section{Umatilla Basin Ground-Water Study Planning (Oregon)}

The Confederated Tribes of the Umatilla Indian Reservation, Oregon Water Resources Department (OWRD), and USGS continued evaluating the ground-water resources in the Umatilla basin with special focus on ground-water/surface-water interaction and the decline in water levels in the Columbia River Basalt aquifer. A large multi-year regional study was proposed. The OWRD and the Tribes provided support for the USGS to collect continuous water levels in selected wells, compile existing well and water-level data, and collect borehole geophysical data in wells open to the basalt aquifer. The geophysical data will help identify the permeable zones and provide information to help manage development of the aquifer. Permeable zones within the basalt aquifer exist at the top and bottom of individual basalt flows that comprise the basalt aquifer. The Columbia River Basalt aquifer can produce large quantities of water; however, the storage capacity of the basalts is limited. As a result, water levels in the aquifer are declining in many parts of the basin and there is concern about the impact of these changes to the hydrologic system on discharge to streams. Recent meetings between the Tribes, OWRD, U.S. Bureau of Reclamation, and USGS continue the process of developing a detailed scope of work for a comprehensive ground-water investigation in the basin. Contact: Terrence Conlon, 503-251-3232, tdconlon@usgs.gov

\section{Spring Chinook Salmon on the Deschutes River (Oregon)}

USGS fishery biologists continue cooperating with the Confederated Tribes of the Warm Springs Reservation in the fourth year of a study on the Deschutes River in Oregon. The study will help to determine the distribution, migration behavior, habitat use, and species interactions of juvenile spring Chinook salmon raised in hatcheries and released in the fall on the Deschutes River. In this part of the study, USGS scientists are helping staff at the Warm Springs National Fish Hatchery evaluate whether or not changes in how they raise juvenile salmon improve the likelihood of the fish migrating to the sea. The USGS will develop non-lethal measurement techniques that will predict the behavior of the fish. Working together, scientists from the Confederated Tribes of the Warm Springs Reservation, U.S. Fish and Wildlife Service, and the USGS are sharing the responsibilities for in-stream sampling during this study. Contact: Jim Petersen, 509-538-2299, ext. 236, jim_petersen@usgs.gov

\section{Quantifying the Ground-Water Resources of the Upper Klamath Basin (Oregon, California)}

Ground water has long been considered a possible source to meet the increasing demands for water in the upper Klamath basin. A quantitative understanding of the regional groundwater system is crucial to managing water resources in the basin. However, the amount of ground water that can be pumped without adversely affecting existing well users and streamflow is not well understood. The USGS is conducting a 7-year investigation that continues through FY 2005 to quantify the ground-water resources of the upper Klamath basin. Information obtained through these studies will help determine how ground water can be used to help solve water-supply problems while maintaining ground-water discharge to streams that are critical for aquatic wildlife. The Klamath Tribes reside in the upper Klamath basin study area. Three additional Tribes (Hoopa Valley, Yurok, and Karuk) reside in the lower basin. All of these Tribes are interested in water resources management in the basin and in the results of the present study. Project personnel have communicated with Tribal representatives and, in the case of The Klamath Tribes, have worked with Tribal members to obtain access to certain properties and wells for data collection. Tribal representatives have attended some project-related meetings. In August 2004, the USGS project chief made a presentation on the preliminary findings of the project to the regular government-to-government meeting held between Federal agency and Tribal representatives. Contact: Marshall Gannett, 503-251-3233, mgannett@usgs.gov

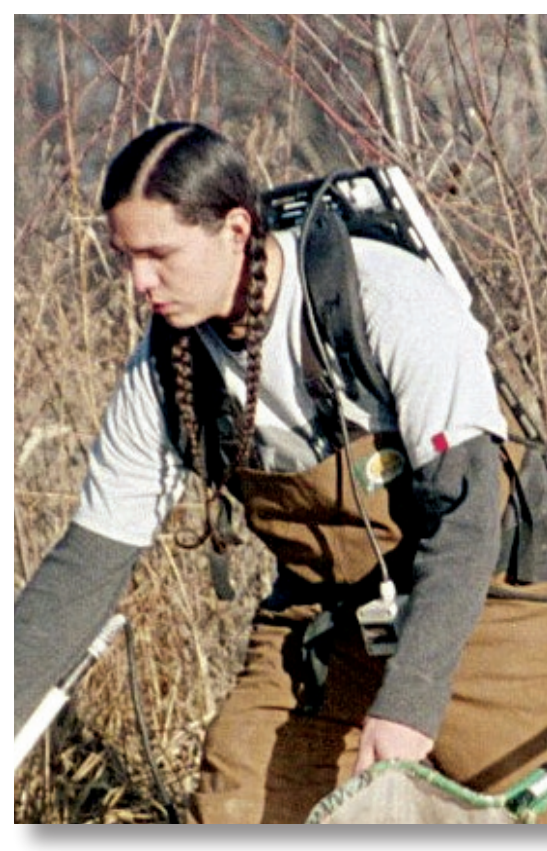




\section{Anadromous Fishery Restoration (Oregon, California)}

In 2004, USGS ecologists continued their participation in the Trinity River Restoration Program (cooperating with the Yurok and Hoopa Valley tribes) and the Klamath River Basin Fisheries Task Force (cooperating with the Yurok and Karuk tribes). The U.S. Fish and Wildlife Service (Arcata, California, office) is the lead Department of the Interior bureau for coordinating on-the-water sampling of adult and young-of-year salmon and their habitat, with the USGS Fort Collins Science Center collaborating with funding, design, and implementation of the sampling. Sampling data from past years is being analyzed to improve the Klamath River System Impact Assessment Model (SIAM) and the Trinity River young-of-year salmon production model (SALMOD). The goal for both models is to provide a better understanding of water quantity and habitat problems that limit salmonid production. SIAM is available through the USGS Fort Collins Science Center Web site, as is the user's guide (http://www.fort.usgs.gov/products/software/ siam/siam.asp). Contact: Dave Hamilton, 970-226-9383, dave_hamilton@usgs.gov

\section{Amphibian Surveys on Tribal Lands (California)}

USGS scientists from the Western Ecological Research Center are conducting surveys on two Federally listed amphibian species as part of a Tribal Habitat Conservation Planning (HCP) program for the Agua Caliente Band of Cahuilla Indians. The Federally endangered mountain yellow-legged frog (Rana muscosa) and the Federally threatened California red-legged frog (Rana aurora) both historically occurred throughout the area. Both species have declined dramatically in the past several decades, and surveys were initiated to determine habitat suitability and current status of the two species within the planning area. To date, neither species has been detected. Contact: Robert N. Fisher, 858-637-3882,rfisher@usgs.gov or Adam R. Backlin, 760-931-1101 ext.235, abacklin@usgs.gov

\section{Walrus Research (Alaska)}

Walrus are important culturally and are a source of subsistence food and traditional materials for Alaska Natives and Russians, who harvest the animals annually. However, the size and trend of the walrus population are unknown, mostly due to problems with survey methods. The USGS and U.S. Fish and Wildlife Service have created a Pacific Walrus Survey Team to develop new survey techniques. The team is developing an aerial thermal imaging technique for counting walruses on ice, a remotely deployed satellite-linked transmitter to allow estimation of the proportion of the population not on the ice, and an overall survey design with associated estimation methods. Project scientists have received advice and help in field work from Alaska Native hunters. Such cooperation was facilitated through meetings with the Eskimo Walrus Commission. The results of these ongoing studies, publications, and other datasets will be available through the following Web site: http://www.absc.usgs.gov/research/walrus/home.html Contact: Chad Jay,907-786-7414, chad_jay@usgs.gov

\section{Water-Quality Sampling of the Taku River (Alaska)}

The Douglas Indian Association (DIA), the Alaska Department of Environmental Conservation, and the USGS Alaska Science Center are documenting a 5-year cooperative water-quality project in a report to be completed next year. The study will establish baseline water-quality data for the Taku River. The water quality in this undeveloped watershed may be affected by a new mine that has been proposed on the Canadian side of the watershed. The Taku River is also subject to glacial outburst floods that affect the river's water quality. USGS scientists collected water samples in the river, and the U.S. Environmental Protection Agency is analyzing the samples. The DIA provided an intern to assist USGS researchers with the sampling for part of the project. Contact: Steve Frenzel, 907-786-7107, sfrenzel@usgs.gov 


\section{Surficial Geologic Mapping near Tanacross (Alaska)}

Surficial geologic mapping is underway along a section of the Alaska Highway near Tanacross, Alaska. A high-pressure natural gas pipeline route is proposed to run parallel to the highway from Fairbanks to the Yukon. The USGS will provide mapping information for land-use decisions along the proposed route. Tanacross Inc. owns about 25 percent of the land being mapped by this project. Results of the mapping will be shared with the Tanacross Tribal Council, and the mapping will be used by the Tribe to identify economic gravel resources and permafrost areas. The project has produced surficial geologic maps of the Tanacross B6 and B5 quadrangles (USGS Scientific Investigations Maps 2850 and 2856, respectively) and will produce a surficial geologic map of the Tanacross B4 quadrangle. Contact: Paul Carrara, 303236-1287, pcarrara@usgs.gov

\section{Aniak Mining District Geologic Map Compilation (Alaska)}

The USGS is cooperating with the U.S. Bureau of Land Management (BLM) on a fiveyear regional study in southwest Alaska that will benefit two Alaska Native Regional Corporations-Calista and Doyon. BLM's Aniak Mining district study encompasses 29.6 million acres of Federal, State, and Native Corporation land in an area of past gold and mercury production. The area may contain additional undiscovered gold and other resources. The USGS brings local expertise to the cooperative project, having previously performed 1:250,000-scale geologic mapping and an assessment of undiscovered resources for about half of the area. The USGS has compiled a geologic map of the mining district as an underlay for the BLM studies. Although the main USGS contributions have been completed, the USGS continued to provide information to the BLM in FY 2004 to assist them with this project. Contact: Marti L. Miller, 907-786-7437,mlmiller@usgs.gov

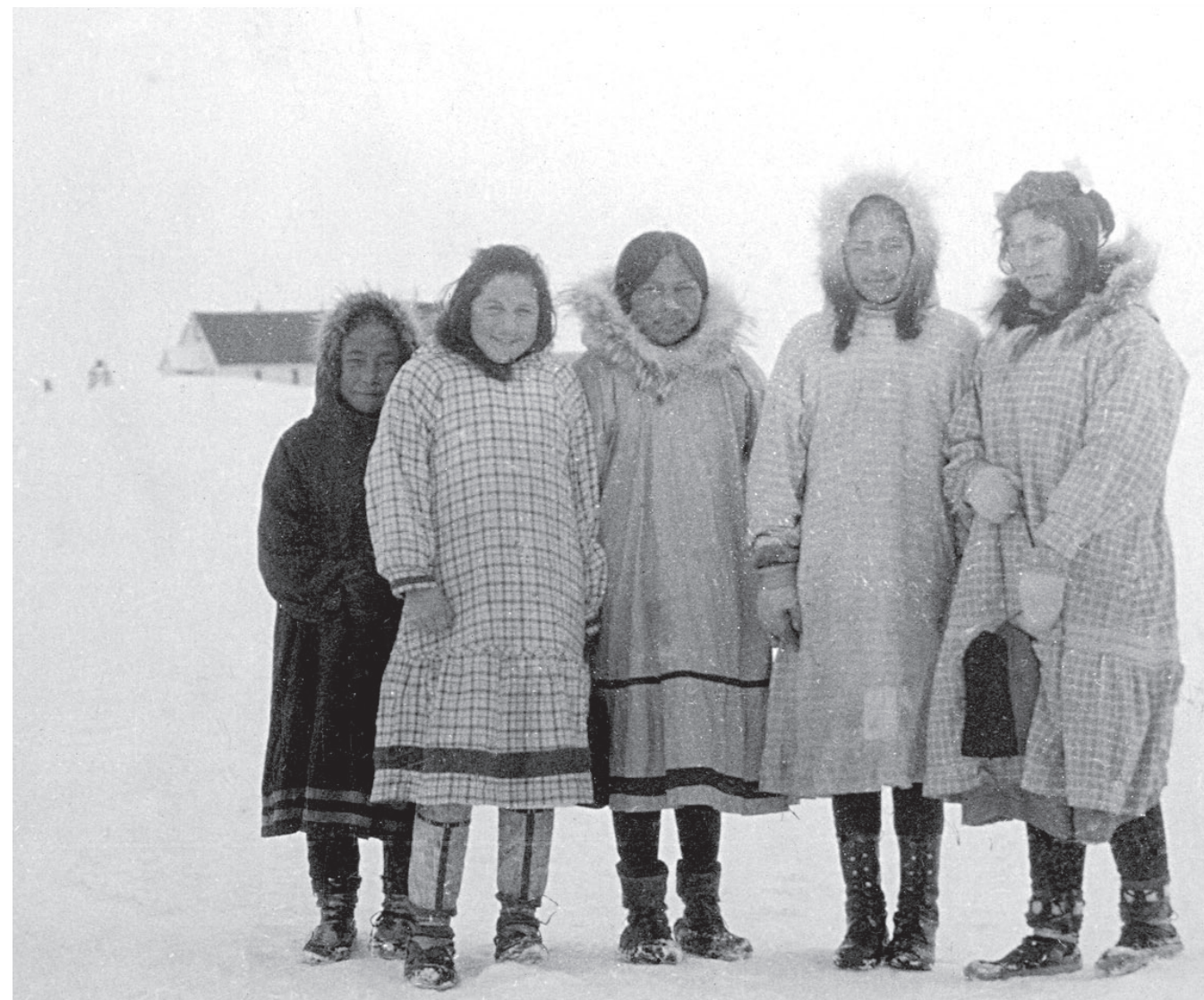

Young Alaska Native girls at Kotzebue, Alaska, April 10, 1925. USGS Photographic Library; photograph by W.R. Smith. 




Alaska Native John Eneyuk collecting pan concentrate samples in southwestern Alaska. The sampling effort is part of a CRADA (Cooperative Research and Development Agreement) between the USGS and the Bristol Bay Native Corporation. Photograph by Elizabeth Bailey.

\section{Mineral Resources Studies in Southwestern Alaska}

The USGS began a new field-based mineral resource study in southwestern Alaska in 2004. This region is geologically interesting for undiscovered metallic resources; however, it is a geologic frontier because what is known primarily comes from expeditions conducted more than 60 years ago. Collection of basic geologic, geochemical, and geophysical data is expected to facilitate mineral exploration, assist in land-use planning, and may encourage economic development. The study area is within the Bristol Bay Native Corporation (BBNC) region. $\mathrm{BBNC}$ is very interested in bringing resource development to their region and has proposed to contribute to the USGS study by assisting in collection of stream-sediment samples. The USGS and BBNC have entered into a Cooperative Research and Development Agreement (CRADA) for this purpose. Under the agreement, new geochemical data will not be held proprietary, but will be published immediately to the benefit of the public at large. Contact: Marti L. Miller, 907-786-7437,mlmiller@usgs.gov 


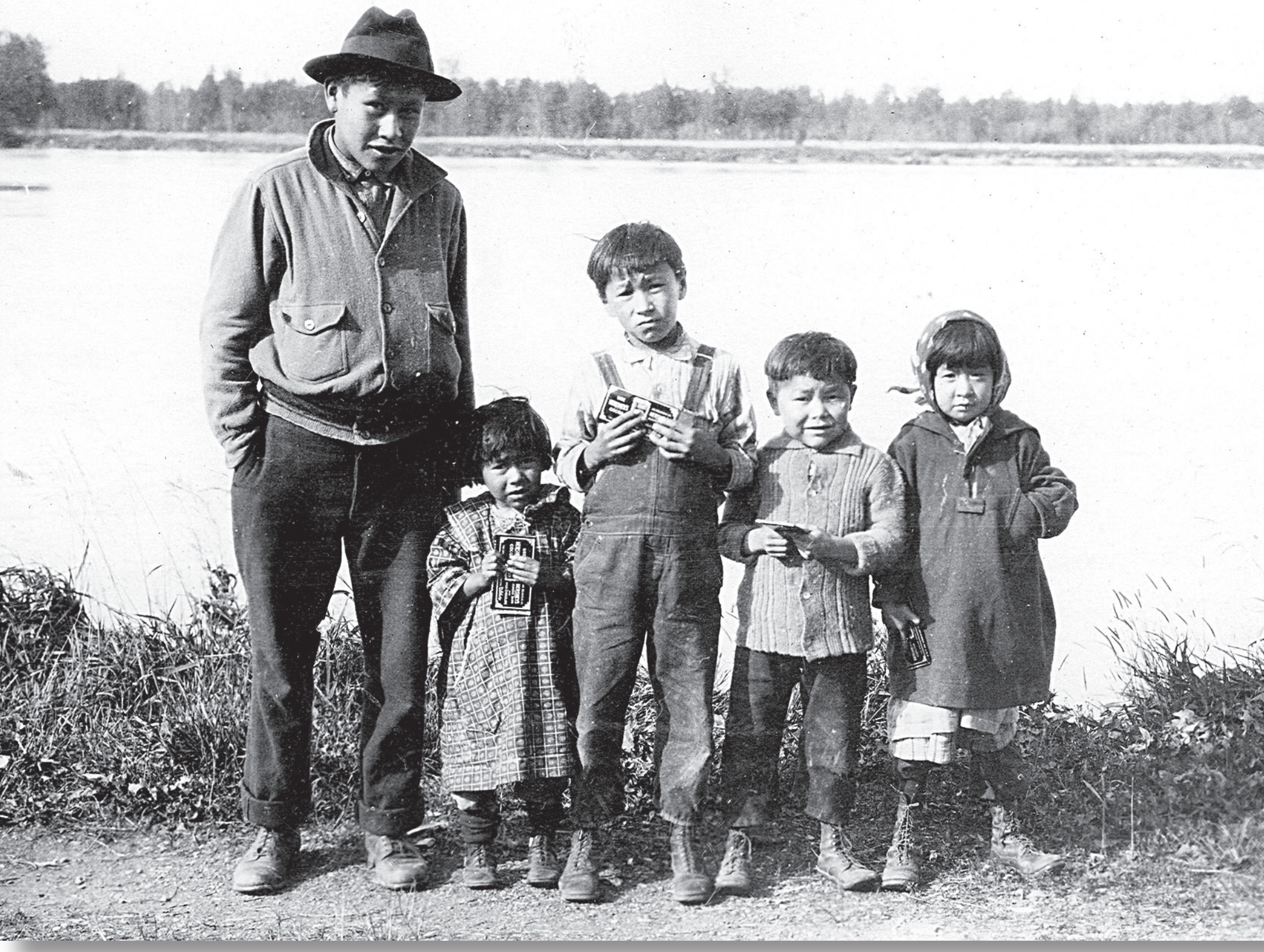

Alaska Native children at Susitna Station, Alaska, about 1925. USGS Photographic Library; photograph by S.R. Capps.

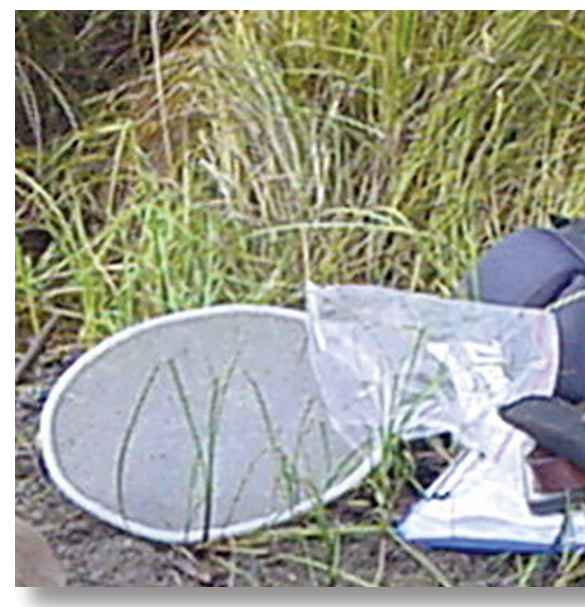




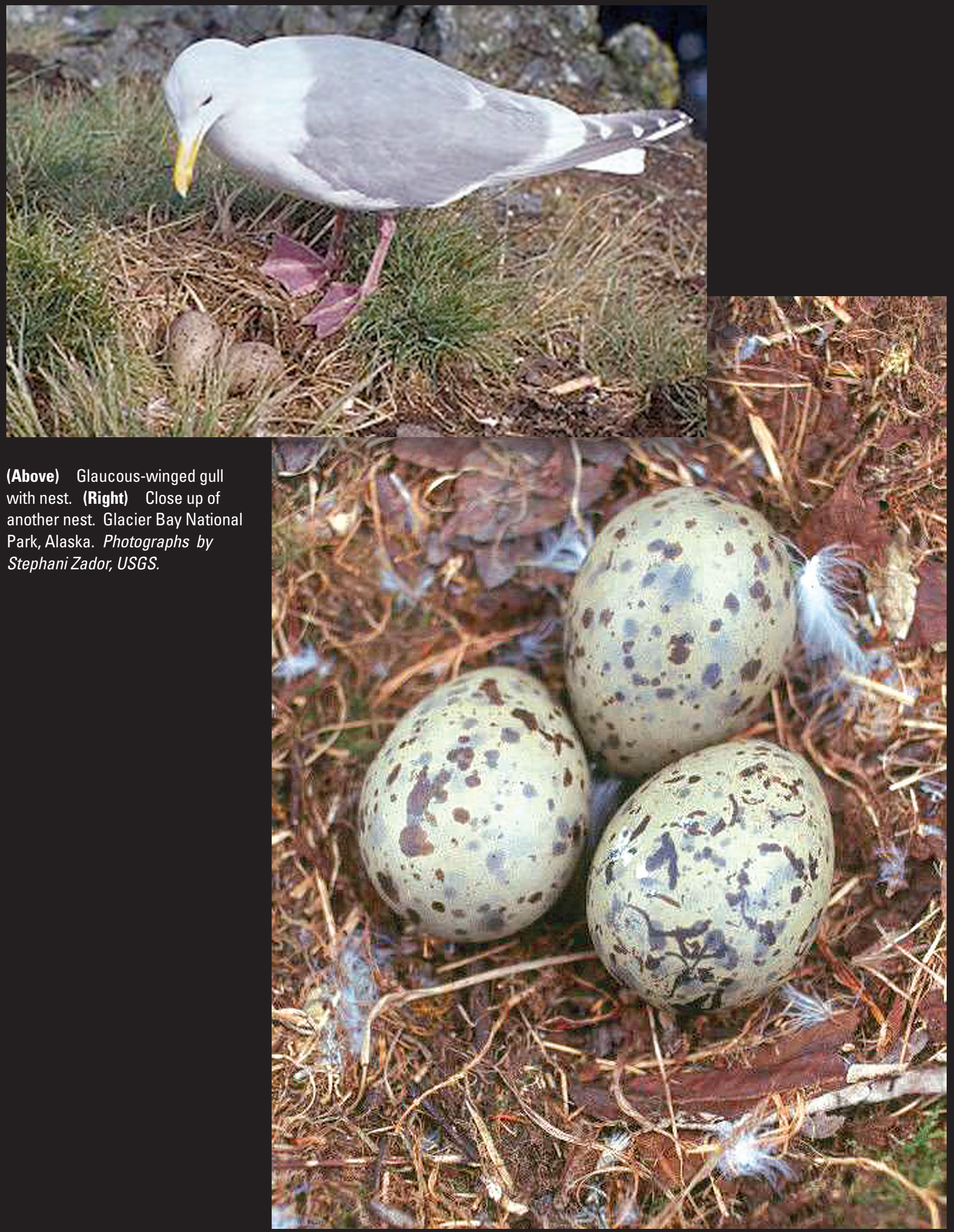




\section{Evaluating Natural Gas from Coal for Electricity Generation at Fort Yukon-Doyon Ltd. (Alaska)}

Remote Alaska villages have high energy costs, typically 3-5 times that of urban Alaska, for electricity and heating. The residential electric rate in Fort Yukon is currently 46 cents/ kilowatt-hour compared to 10 cents/kilowatt-hour in Fairbanks. These costs are driven by the need to import diesel and heating fuels to the villages. Finding and developing locally available energy resources is key to reducing energy costs in rural Alaska. One potential source of energy is natural gas from coal. Coal seams underlie many Alaskan villages but traditional drilling methods are too expensive and are not well suited for exploration in remote Alaska. This project involved a test of a lightweight low-cost drilling technology in Fort Yukon during the summer of 2004. It was conducted by a partnership between the U.S. Department of Energy, U.S. Bureau of Land Management, Alaska Division of Geological \& Geophysical Surveys, University of Alaska Fairbanks, and the USGS. This cooperative effort has the support of Gwitchya Zhee Corporation (Fort Yukon) and Doyon Ltd. The project is intended to demonstrate the use of a lightweight drill rig for exploration and development of natural gas from coal, and to assess the economic feasibility of extracting natural gas from coal in remote Alaskan villages using this technology. Contact: Charles Barker (coal and coal bed methane analysis), 303-236-5797, barker@usgs.gov or Art Clark (geology, well testing and drilling technology), 303-445-4608,aclark@usgs.gov

\section{Alaska Volcanoes and Alaska Natives}

Open communication between Alaska Natives and the USGS Alaska Volcano Observatory (AVO) is crucial in helping to safeguard Alaskan communities from geologic hazards. Numerous Alaska Native villages and corporations communicate with the AVO during periods of volcanic activity. Alaska Native officials transmit on-site observations to AVO, and AVO scientists distribute interpretive and hazards information to the Native communities. Many of these communities are on the AVO automatic weekly update fax and (or) electronic mail lists that provide the activity status of more than 40 active volcanoes in the Aleutian Islands. All Alaska Native villages in the Aleutians, including Nelson Lagoon, Naknek, Unalaska, Akutan, False Pass, Atka, King Cove, and Perryville, are near active volcanoes. AVO scientists also conduct geological field studies, and they service existing seismic-monitoring equipment that provides real-time warnings of volcanic activity and related hazards to aircraft and local communities. The USGS obtained letters of non-objection for proposed volcano hazards work and for accessing lands owned or selected by several Alaska Native corporations, including The Aleut Corporation, Akutan Corporation, Ounalashka Corporation, Ahtna Incorporated, and Cook Inlet Region Incorporated. On April 19, 2004, activity at Mount Veniaminof volcano increased, and AVO announced that the volcano was restless (level of concern = yellow). The volcano is about 22 miles from the Alaska Native village of Perryville. For the next several months, Veniaminof routinely erupted ash to 10,000 feet above sea level. A volcanologist from AVO traveled to Perryville to discuss the hazard posed by the volcano, explaining to Perryville inhabitants that at the existing level of activity, light ash fall was the most likely volcanic hazard. Data received by AVO from its seismic network on the volcano showed no signs of more energetic activity and thus no action needed to be taken by the village. Activity declined and on October 26, 2004, AVO declared the volcano back in its normal dormant state (color code green). Contact: Thomas Murray,907-786-7443, tlmurray@usgs.gov

(Facing Page) Alaska Natives at a fishing village at the foot of Sixmile Lake, Kenai Peninsula, Alaska, about 1925. USGS Photographic Library; photograph by S.R. Capps. 
Whis

ivatio

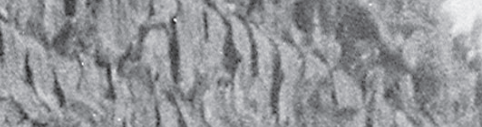

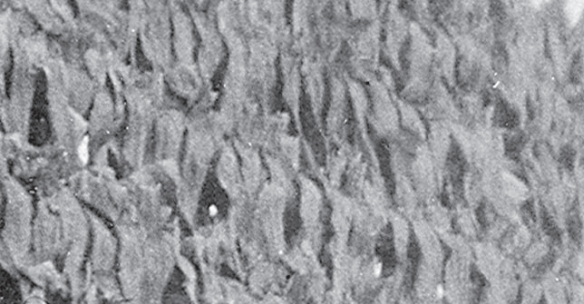

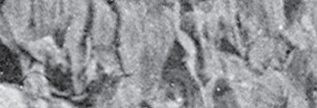

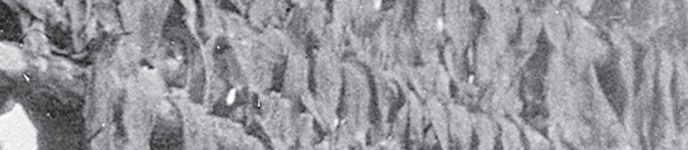

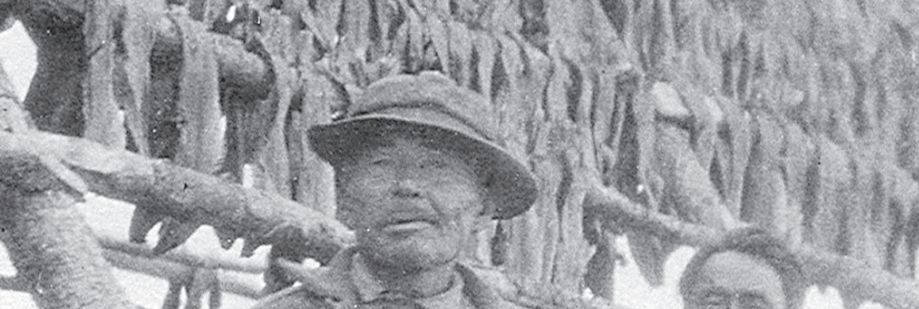

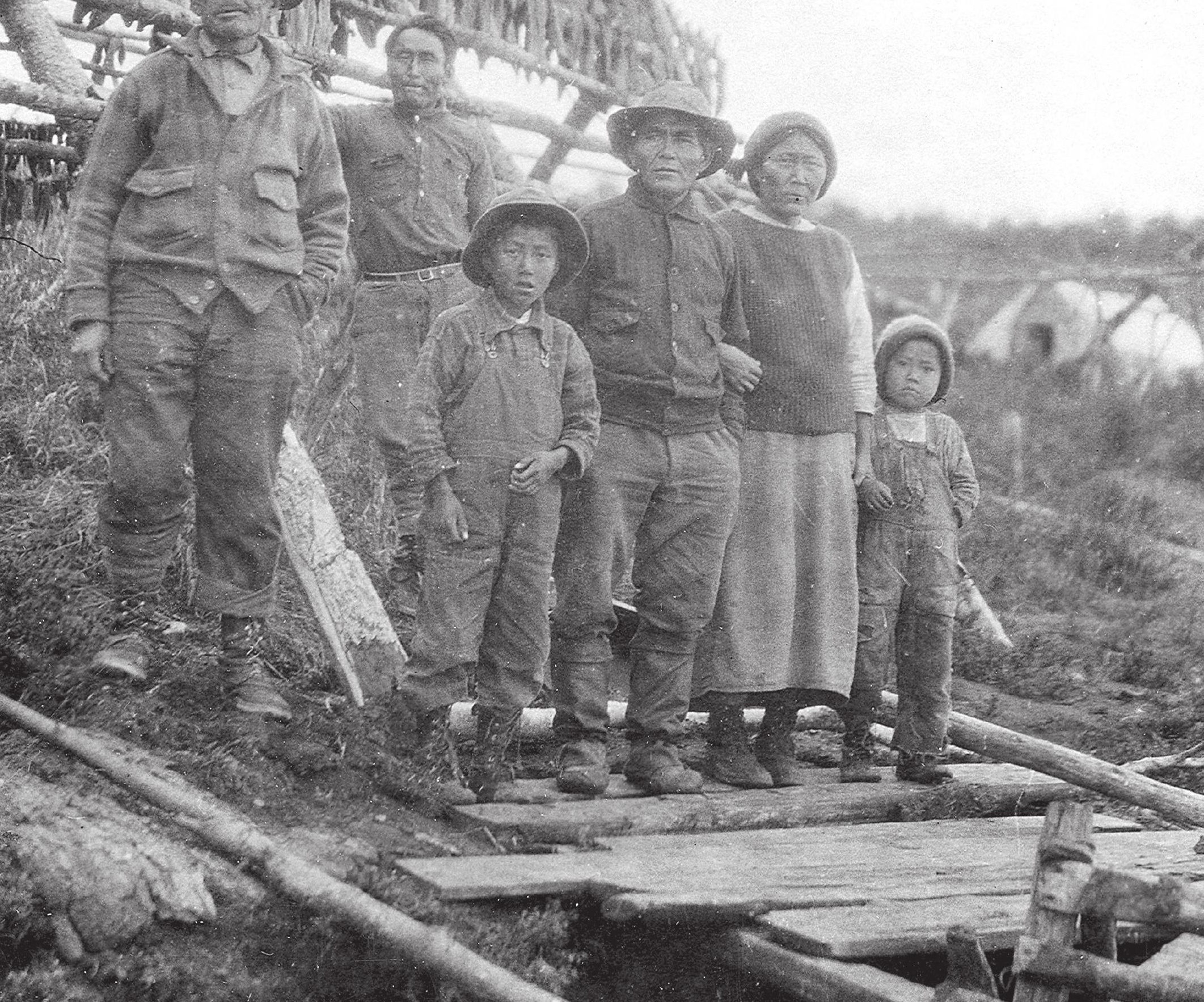




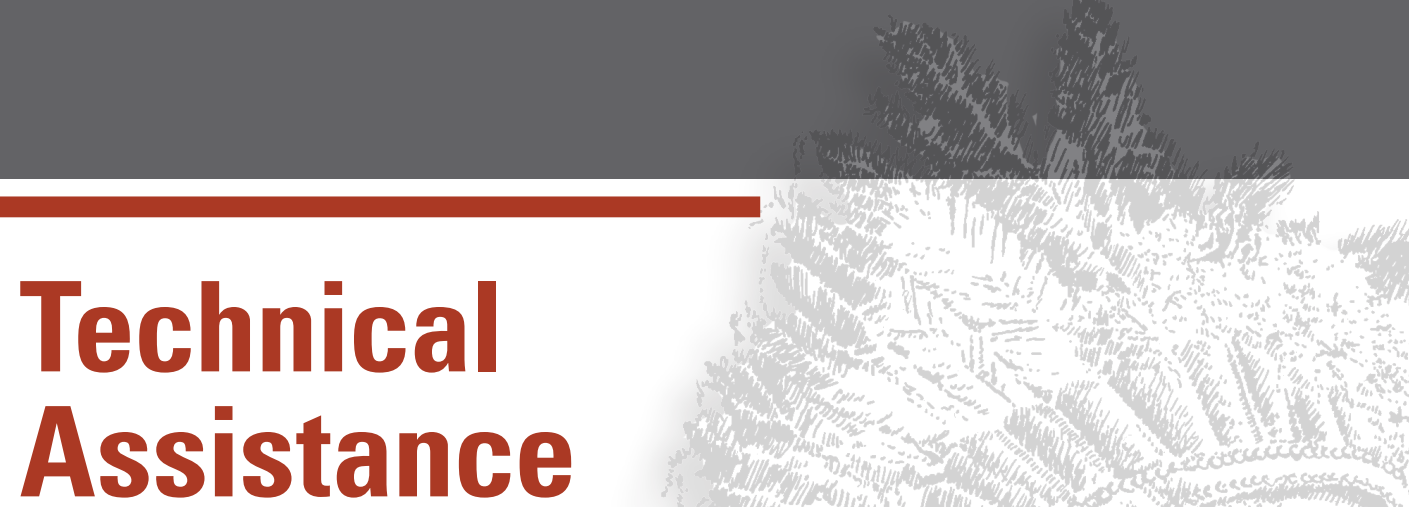

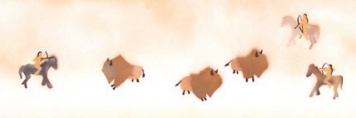
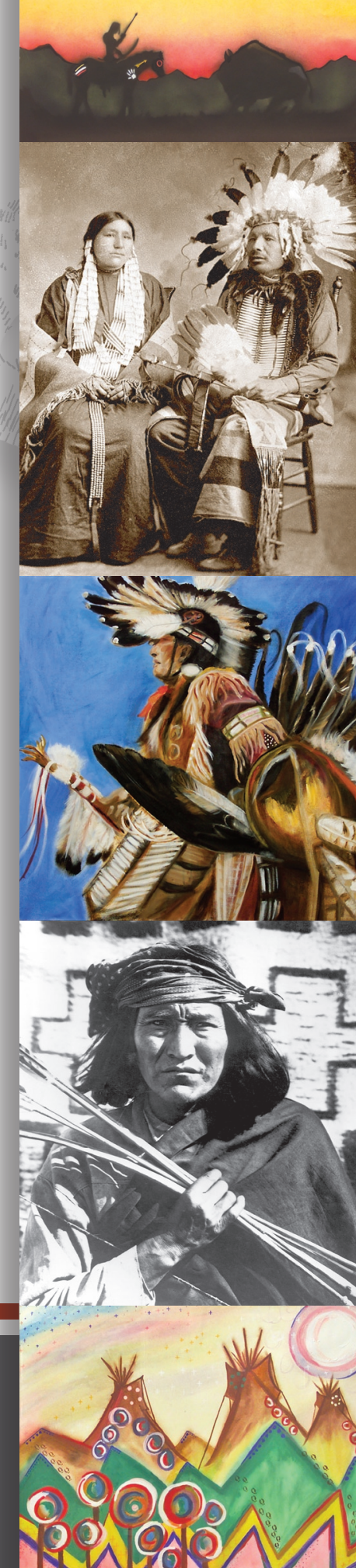
Table 1. Fires mapped by USGS EROS for DOI Emergency Response Burn Severity Mapping Project, FY 2004.

[Acreage is total fire acreage, including Native American and Non-Native American ownership. Includes only large fires in Alaska with generally over 50,000 acres of Alaska Native Corporation ownership. Many smaller fires were also mapped]

\begin{tabular}{llccc}
\multicolumn{1}{c}{ Fire name } & Location & $\begin{array}{c}\text { Native American } \\
\text { entities }\end{array}$ & Fire year & $\begin{array}{c}\text { Total acres } \\
\text { (all ownership) }\end{array}$ \\
\hline Billy Creek & AK & Doyon Limited & 2004 & 465,746 \\
Pingo & AK & Doyon Limited & 2004 & 300,293 \\
Porcupine & AK & Doyon Limited & 2004 & 284,594 \\
Bonanza Creek & AK & Doyon Limited & 2004 & 248,778 \\
Evansville & AK & Doyon Limited & 2004 & 122,155 \\
Deer Creek & AK & Doyon Limited & 2004 & 101,318 \\
Fort Hamlin Hills & AK & Doyon Limited & 2004 & 98,279 \\
Lower Mouth & AK & Doyon Limited & 2004 & 58,679 \\
Encebado & Taos (NM) & Pueblo of Taos & 2003 & 5,400 \\
\hline & & & Total & $\mathbf{1 , 6 8 5 , 2 4 2}$ \\
\hline
\end{tabular}




\section{Technical Assistance}

\section{Diagnostic Services}

The USGS National Wildlife Health Center (NWHC) provided diagnostic services to several Tribal organizations in 2004. Three diagnostic cases involved submissions of specimens that originated from Native Americans. In two of the submissions [(1) king eider and emperor goose from Alaska and (2) tufted puffins, pelagic cormorant, and black-legged kittiwake from Alaska)], the specimens were submitted to U.S. Fish and Wildlife Service (FWS) refuges for shipment, and the FWS did not provide the names of the Alaska Native agency that collected the samples. USGS also received moose tissues for evaluation directly from the Spokane Tribe in Wellpinit, Washington. Contact: Kathy Converse, 608-270-2485, Kathy_Converse@usgs.gov

\section{Technical Assistance}

Scientists at the USGS Western Fisheries Research Center (WFRC) in Seattle, Washington, continue their strong commitment to respond to requests for technical assistance and scientific information from the Department of the Interior bureaus, Tribal and State fisheries agencies, and private sector aquaculture. The assistance provided by WFRC is in the form of technical support, laboratory services, education and training, technology transfer, and rapid response concerning fish disease and other aquatic animal health issues. The Northwest Indian Fisheries Commission and biologists at other northwest Tribes are important clients for these services, which include technical assistance needs related to management of Tribal Fish Hatcheries and tactical research on diseases affecting salmonids and other fishes, including threatened, endangered, and sensitive species. Activities of the WFRC in the past year include consultation with fish-health biologists regarding tumors of unknown etiology affecting Chinook salmon reared by the Nez Perce Tribe and reference laboratory service to identify an unknown virus in samples submitted by the fish-health staff from the Northwest Indian Fisheries Commission. Contact: Lyman Thorsteinson, 206-526-6282, lyman_thorsteinson@usgs.gov

\section{USGS Information Helps Fire Management on Tribal Lands}

The USGS National Center for Earth Resources Observation and Science (EROS) provided imagery and analyses in response to the needs of Federal Burned Area Emergency Response (BAER) teams, local resource managers, and other non-Federal land managers responsible for managing and assessing impacts of wildfires. In FY 2004, EROS responded to requests for wildfire mapping services on nine fires impacting Native American lands, predominantly in Alaska (table 1). EROS staff obtained satellite images of the burned areas before and after the fire. The staff then generated an estimate of burn severity by comparing the pre-fire and post-fire images. The resulting EROS preliminary burn severity maps and associated prefire and post-fire satellite images were provided to the BAER team for immediate use in generating their official and final soil burn severity map. The BAER team and other managers were able to refine USGS preliminary data and maps based upon field assessments and local experts. The final soil burn severity map was the basis used to develop many of the BAER team's subsequent assessments, actions, and recommendations. The local managers were provided with a copy of all maps and images for future resource management applications. Contact: Randy A. McKinley, 605-594-2745, rmckinley@usgs.gov 


\section{Surface-Water Gaging Station and Temperature Probe, Keweenaw Bay Indian Community (Michigan)}

USGS hydrologists are working with the Keweenaw Bay Indian Community (KBIC) Environmental Department to monitor the Silver River, which flows into Lake Superior's L'Anse Bay. Upstream from the gaging station, this river has a watershed of 64 square miles and it drains highlands in part of Baraga County, Michigan. Since 2001, the USGS has installed a continuous-data stream-gaging station and a water temperature gage on the Silver River. Temperature, stage, and streamflow data from the gage are available on a real-time basis. The KBIC and other interested parties are currently investigating installation and operation of another continuousdata stream gaging station on the Falls River, which drains about 45 square miles adjacent to the Silver River basin and which also flows into L'Anse Bay on Lake Superior. L'Anse Bay and Keweenaw Bay provide habitat for a diverse aquatic population supporting sport and commercial fishing activities, and the Bays also provide drinking water for three communities located adjacent to the Bays. The KBIC is also concerned about the environmental impact of future development within the Silver River watershed and is planning a multi-year cooperative study with the USGS of water quality and streamflow of the Silver River and its many tributaries. The multi-year study is expected to begin as soon as a Quality Assurance Program Plan is approved and Tribal funding is available. Contact: Tom Weaver, 906-786-0714, tlweaver@usgs.gov

\section{Surface-Water Studies with the Keweenaw Bay Indian Community (Michigan)}

In October 2004, USGS employees installed continuous-data stream-gaging stations and temperature and specific conductance probes on the Salmon Trout and Yellow Dog Rivers in a cooperative project with the Keweenaw Bay Indian Community (KBIC). The Salmon Trout and Yellow Dog River watersheds upstream of the gages are about 7 square miles and 32 square miles, respectively. Both rivers, which drain into Lake Superior, are noted for their diverse aquatic populations and species abundance. The KBIC and other interested parties are concerned about the environmental impact of future development within the watersheds, which are located west of Big Bay in northern Marquette County, Michigan. Stage, temperature, and specific conductance data from the gages are available on a real-time basis. Additional streamgaging sites are expected to be installed in the future. Contact: Tom Weaver, 906-786-0714, tlweaver@usgs.gov

\section{Water Resources Investigation of Tribal Lands, Nottawaseppi Huron Band of Potawatomi (Michigan)}

Tribal members of the Nottawaseppi Huron Band of Potawatomi living on the Reservation depend upon domestic water from fairly shallow wells completed in unconsolidated glacial and lacustrine deposits. Three small tributaries of the St. Joseph River system pass through agricultural land prior to crossing the Reservation. In FY 2000, the Tribe and the USGS agreed to cooperate in a 4-year study to investigate flow characteristics and water quality of streams near the Reservation, in Calhoun County, Michigan. The study included sampling tribal groundwater wells for agricultural pesticides. USGS and Tribal environmental staff worked cooperatively on several aspects of the data collection and analytical effort. A USGS Open-File Report (OF 2004-1406; "Water resources on and near the Nottawaseppi Huron Band of Potawatomi Indian Tribal Lands, Calhoun County, Michigan, 2000-03," by T.L. Weaver, D. Healy, and T.G. Sabin) summarizes data collection activities and other hydrologic information that will assist the Tribe in future planning efforts. Tribal planners and environmental staff will continue to be challenged by water management issues related to housing development and widespread agricultural activities.Contact: Tom Weaver, 906-786-0714, tlweaver@usgs.gov 


\section{Water-Resources Investigation with the Lac Vieux Desert Band of Lake Superior Chippewa Indians (Michigan)}

A cooperative, 4-year study of surface-water quality and basin characteristics of Lac Vieux Desert was begun in FY 2002. The 6.6-square-mile lake straddles the Michigan-Wisconsin border and is the headwaters of the Wisconsin River. In May and September 2002 and 2003, seven sites on the lake were sampled for a suite of physical parameters and chemical constituents to help USGS and Tribal scientists determine the general water quality of the 34-square-mile lake basin. In May and August 2004, four sites, including three new sites, were sampled in greater detail for additional information. In addition, streamflow measurements of all tributaries of the lake as well as outflow in the Wisconsin River were made during the 3 years of field work. During the final year of the study, in FY 2005, operation of the real-time lake-level-monitoring station on Lac Vieux Desert was continued and a USGS report was prepared (Weaver, T.L., Neff, B.P., and Ellis, J.M., 2005, Water quality and hydrology of the Lac Vieux Desert Watershed, Gogebic County, Michigan, and Vilas County, Wisconsin, 2002-04: U.S. Geological Survey Scientific Investigations Report 2005-5237, 42 p. http://pubs.water.usgs.gov/SIR20055237). The report summarized data collection and other hydrologic information that will assist future planning by the Lac Vieux Desert Band and by non-tribal entities in the future. Contact: Tom Weaver, 906-786-0714, tlweaver@usgs.gov

\section{Hydrologic Investigations with the Oneida Tribe (Wisconsin)}

The objectives of this cooperative project with the Oneida Tribe of Wisconsin are to collect long-term data at two sites and to perform trend analyses for pesticides, nutrients, and suspended sediment. Results of the study will assist Oneida officials with environmental and developmental planning. Contacts: Kevin Richards (USGS), 608-821-3861, krichard@usgs. gov or Jim Snitgen (Oneida Tribe of Wisconsin), 920-869-5812

\section{Hydrogeology and Ground-Water Flow Near the Indian Mission and Sand Pillow Communities, Ho-Chunk Nation (Wisconsin)}

New housing in the Ho-Chunk Nation's Indian Mission and Sand Pillow communities, other community construction, and planned expansion of the Ho-Chunk casino and hotel are projected to increase demand for water in 5 years to 114,000 gallons per day (gpd). In 20 years, projected demand is 216,000 gpd. Understanding the geology and hydrology of the aquifer is necessary for the Ho-Chunk Nation to create an efficient and sustainable water supply to meet anticipated water demands. Wells in this area have been completed in three different aquifers: crystalline bedrock, sandstone bedrock, and unconsolidated sand and clay. A geologic field investigation and evaluation of existing well and geological data were used to provide input to a regional, single-layer, analytic-element model. Model simulations and geologic information were used to identify locations that had favorable characteristics for providing the quantity of water needed by the Tribe. Test wells have been installed and additional model simulations have been run to assist the Tribe in assessing the contributing areas of those test wells, as well as interference of the wells with each other at different pumping rates. A USGS Water Resources Investigation Report is being prepared. Contacts: Charles Dunning (USGS), 608821-3827, cdunning@usgs.gov or James Dunning (Ho-Chunk Nation Office of Environmental Health),715-284-7548, jdunning@ho-chunk.com 


\section{Real-Time Lake Stage Monitoring for the Prairie Island Indian Community (Minnesota)}

The Prairie Island Indian Community and the USGS Minnesota Water District Office cooperatively maintain two real-time lake-stage monitors. The Community is concerned about stage fluctuations and flooding in Sturgeon Lake that may affect the Tribal residences and pleasure boat traffic adjacent to the Community. Contact: Don Hansen, 763-783-3250,dshansen@usgs.gov

\section{Wetlands Ecology on the Spirit Lake Nation (North Dakota)}

USGS biologists are assisting staff of the Spirit Lake Nation's Tribal Environmental Protection Office in developing and implementing a biological assessment system to monitor the status and condition of wetland resources on Tribal lands. Biologists from the USGS Northern Prairie Wildlife Research Center (NPWRC) are providing onsite assistance to the Tribe so they can select wetlands to monitor and implement biological assessments of plant, invertebrate, and amphibian communities in Tribal wetlands. In addition, the NPWRC is providing taxonomic expertise to assist in identifying aquatic invertebrates and wetland plants. This effort has also included classroom and field workshops on biological monitoring techniques for Tribal staff. Contact: Ned H. Euliss,Jr., 701-253-5564,ned_euliss@usgs.gov

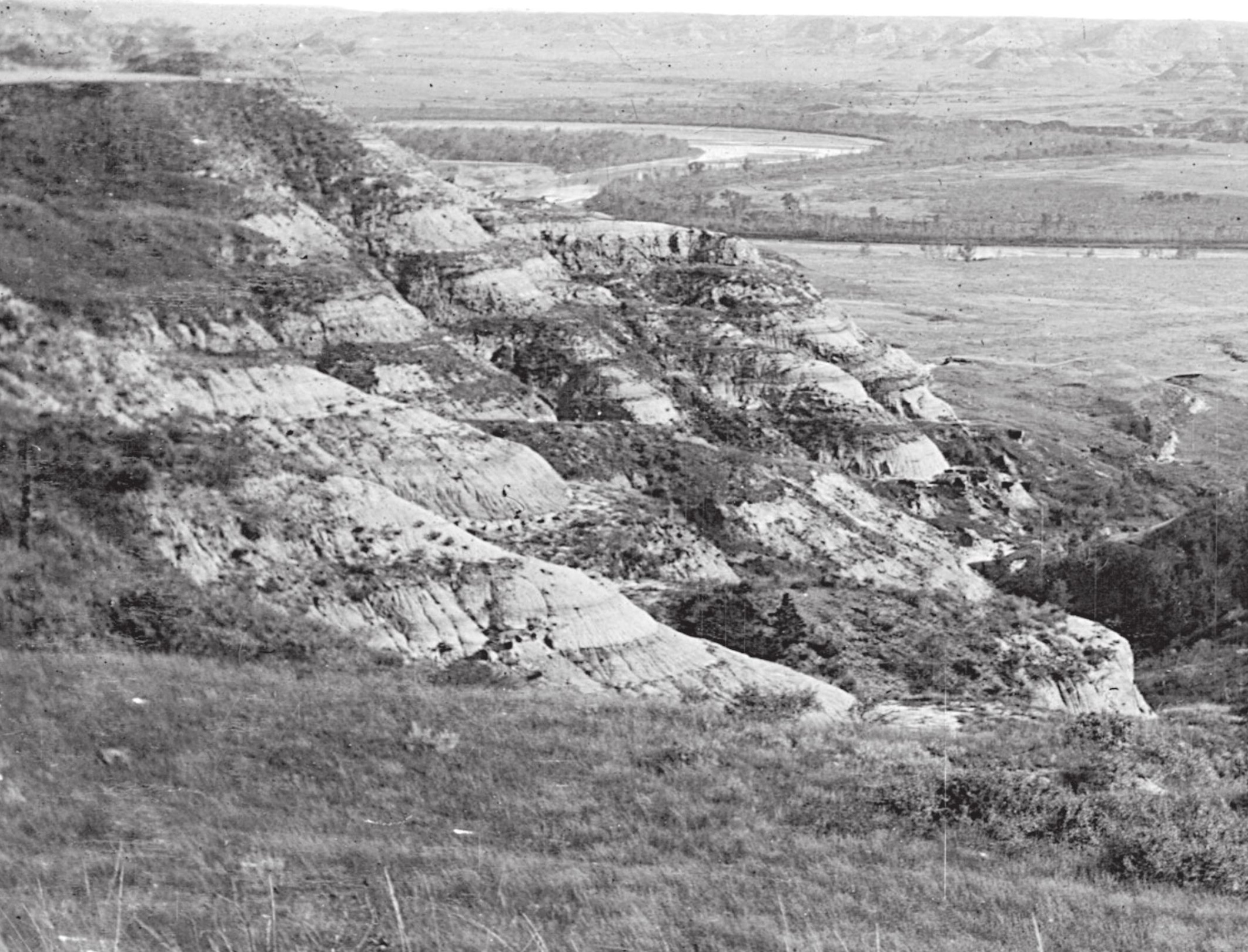




\section{Water-Quality Technical Assistance to Spirit Lake Tribe (North Dakota)}

USGS North Dakota Water Resources personnel provide Spirit Lake Tribal staff technical assistance and quality assurance regarding the collection, processing, and shipping of waterquality samples. The Tribe has their water-quality samples processed by the USGS National Water Quality Laboratory. Contact: Douglas G.Emerson, 701-250-7402, demerson@usgs.gov

\section{Water-Quality Methods, the Kaw Nation (Oklahoma)}

The USGS Oklahoma District conducted a 2-day introductory course on field waterquality methods for surface water for the Kaw Nation Environmental Staff. The course was conducted at the Tulsa Field Office during June 2004. The course included discussions on site selection, proper sampling equipment, equipment cleaning, field forms and checklists, surfacewater sampling theory, and field parameters. The final day of the course included a field trip to a surface water site where the Kaw Tribal members practiced measuring field parameters, collecting water-quality samples, and processing samples. Contact: Kelli DeHay, 918-254-6651, kdehay@usgs.gov
Eroded landscape of the Little Missouri River, looking southeast toward the mouth of Hans Creek, Fort Berthold Indian Reservation, North Dakota, 1913. USGS Photographic Library; photograph by C.M. Bauer.

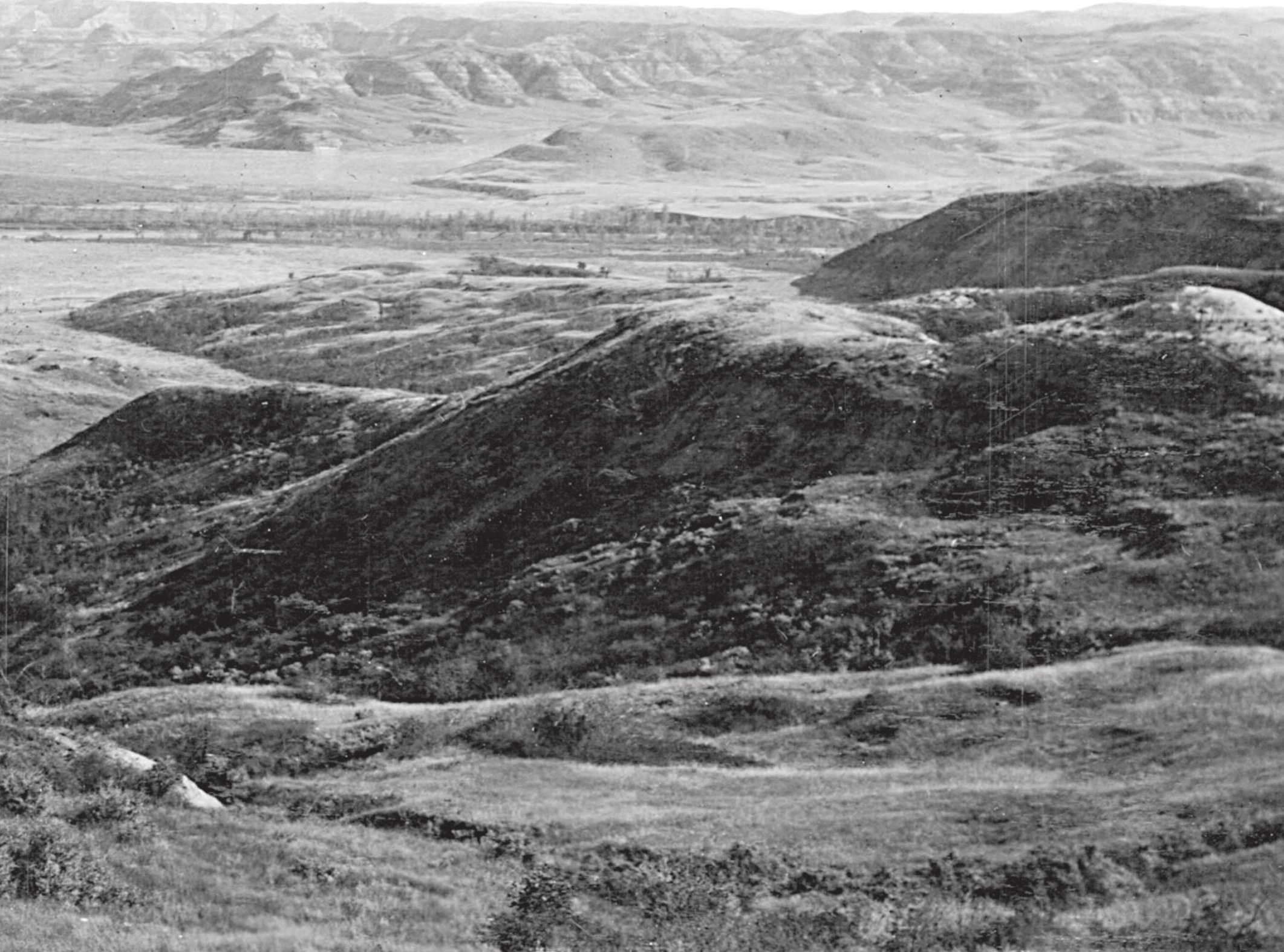




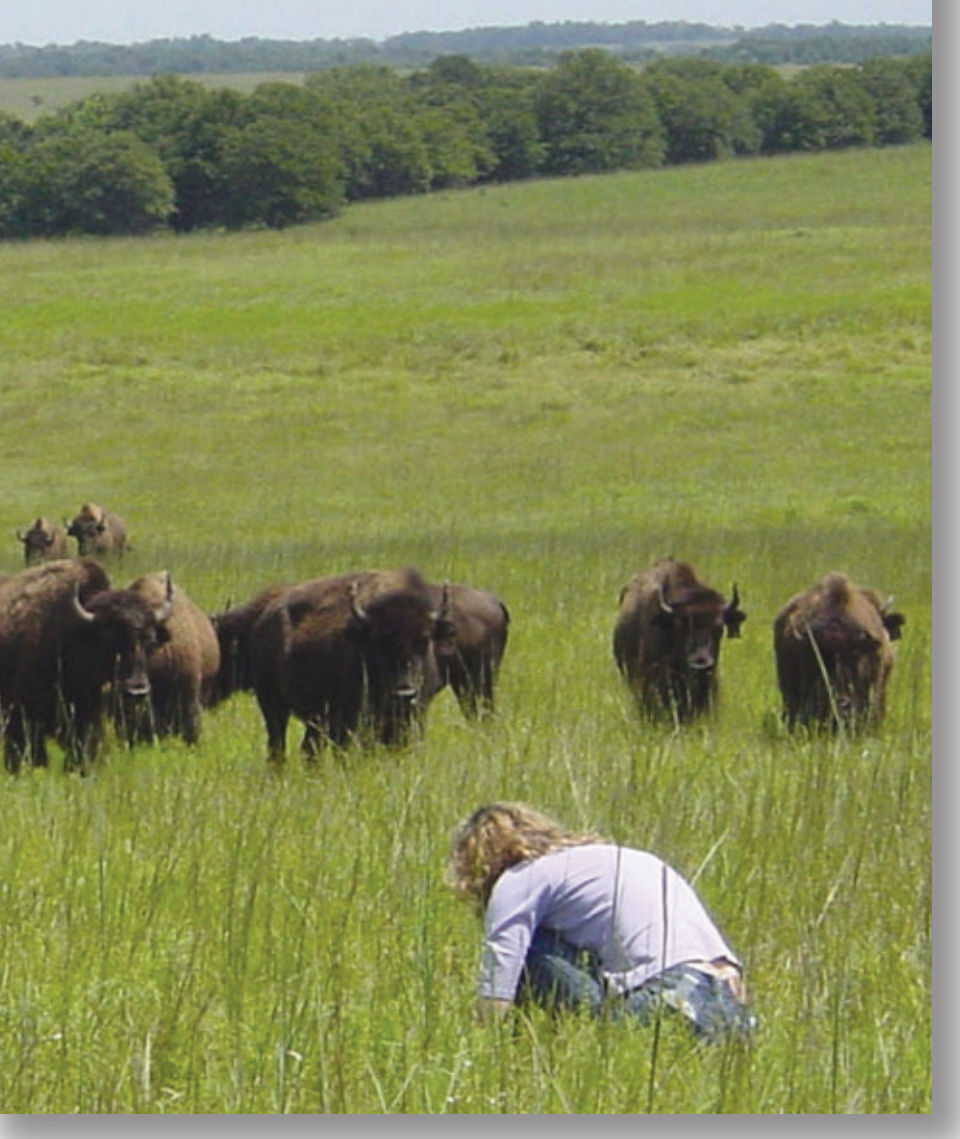

\section{Osage Nation Quality Assurance Training (Oklahoma)}

The USGS Oklahoma District, Tulsa Field Office, conducted a 1-day introductory course on writing quality assurance project plans (QAPPs) for Osage Nation personnel in September 2004. The objectives of the workshop were to help Osage staff understand the value and benefits of an effective quality assurance program and to provide a general understanding of the "data quality objective" concept and have examples and suggestions that work well in approved QAPPs. Another objective of the workshop was to assist Osage staff in identifying and preparing successful QAPPs that will result in U.S. Environmental Protection Agency (EPA) approvals. The training provided participants with the primary elements and concepts of quality assurance, data quality objectives, and associated QAPPs. The USGS provided participants with an example of a QAPP and taught participants how to understand the quality assurance requirements for EPA-funded projects. The session used examples from and suggestions based on approved QAPPs. Contact: Kelli DeHay, 918-254-6651, kdehay@usgs.gov

\section{Biological Habitat Assessment Training, Osage Nation and Sac and Fox Nation (Oklahoma)}

The USGS Oklahoma District, Tulsa Field Office, conducted a three-day course on biological habitat assessment and stream ecology for the Osage Nation and the Sac \& Fox Nation in July 2004. A USGS scientist presented topics relating to algae, macroinvertebrates, fish, National Water-Quality Assessment (NAWQA) protocols, and U.S. Environmental Protection Agency protocols. The first day of the course consisted of classroom lecture and discussions and the last 2 days were spent in the field practicing biological habitat assessment methods. The course also provided training for hydrologists and hydrologic technicians in the USGS Oklahoma District. Contact: Monica Allen, 918254-6651,mlallen@usgs.gov

Carol Becker (USGS) with bison, Turner ranch, Osage County, Oklahoma. Photograph by Diane Daniels, Environmental Coordinator with the Osage Tribe.

\section{Animal Bacterial-Source Tracking Training, Osage Nation (Oklahoma)}

During FY 2004, Osage Nation staff received training on the use of bacterial-source tracking as a tool for determining potential sources of bacteria in surface water. Source samples (feces) were collected from bison, elk, goat, horse, and cattle in the Hominy Creek watershed and sent to the Oklahoma Department of Agriculture, Food, and Forestry (ODAFF) for cultivation and riboprinting of the bacteria isolates. The source samples were used in part to test the accuracy of laboratory techniques used by ODAFF and to help build a riboprint-source library that can be used for future bacterial-source tracking projects in the Hominy Creek watershed. Contact: Carol Becker, 405-810-4436, cjbecker@usgs.gov 

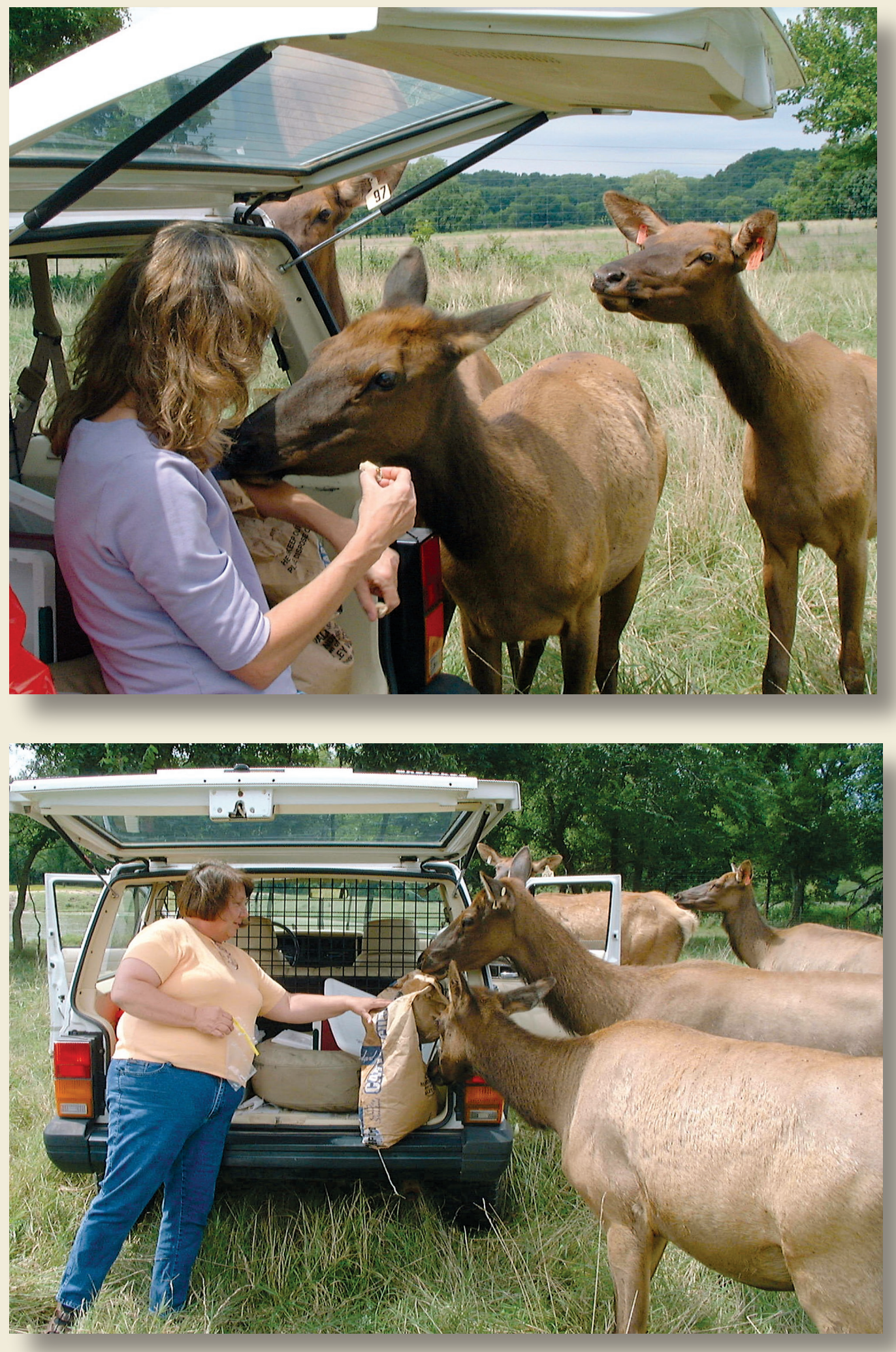

Carol Becker (USGS) at elk refuge, Osage County, Oklahoma. Photograph by Diane Daniels, Environmental Coordinator with the Osage Tribe.

Diane Daniels

(Environmental Coordinator with the Osage Tribe) at elk refuge, Osage County, Oklahoma. Photograph by Carol Becker, USGS. 
(Facing Page) Native American pictograph on sandstone cliff in Apishapa Canyon, Las Animas County, Colorado. The image was made by chipping the "desert varnish" from the weathered surface of the rock. USGS Photographic Library; photograph taken in 1912 by G.W. Stose.

(Below) Bull Lake and distant Wind River Range, Wind River Indian Reservation, Wyoming. USGS Photographic Library; photograph taken July 31, 1923, by W.C. Alden.

\section{Hydrologic Information for the Walker River Paiute Tribe (Nevada)}

During irrigation season, the USGS Nevada Water Science Center continues to collect pH and conductance measurements for the Walker River Paiute Tribe. The information helps the Tribe manage its water quality. Contact: Kerry Garcia, 775-887-7659, ktgarcia@usgs.gov

\section{Boysen Reservior Gage adjacent to the Wind River Reservation (Wyoming)}

The USGS reviewed the records and published data on a stream-flow gage adjacent to the Wind River Reservation of the Northern Arapaho and Eastern Shoshone Tribes. This work was done on behalf of the U.S. Bureau of Reclamation for their use in operating the Boysen Reservoir. Contact: Kirk Miller, 307-778-2931, kmiller@usgs.gov

\section{USGS Assists Southern Ute Tribe with Southwestern Willow Flycatcher Genetic Analysis (Colorado)}

The Southern Ute Tribe asked USGS biologists to catch and genetically sample flycatchers breeding on their land, and to determine the genetic identity of the breeding flycatchers. Since the boundary of the Southwestern Willow Flycatcher's range is near the Tribe's land, the Tribe wanted clarification as to whether flycatchers breeding on their lands are the endangered subspecies or the non-endangered subspecies to the north. In July 2004, a scientist and a USGS volunteer from the USGS Southwest Biological Science Center, Colorado Plateau Research Center, worked with the Southern Ute Tribe to address these Tribal concerns. Analysis of the genetic samples is ongoing. Contact: Eben Paxton, 928-556-7466 ext.229, Eben_Paxton@usgs.gov

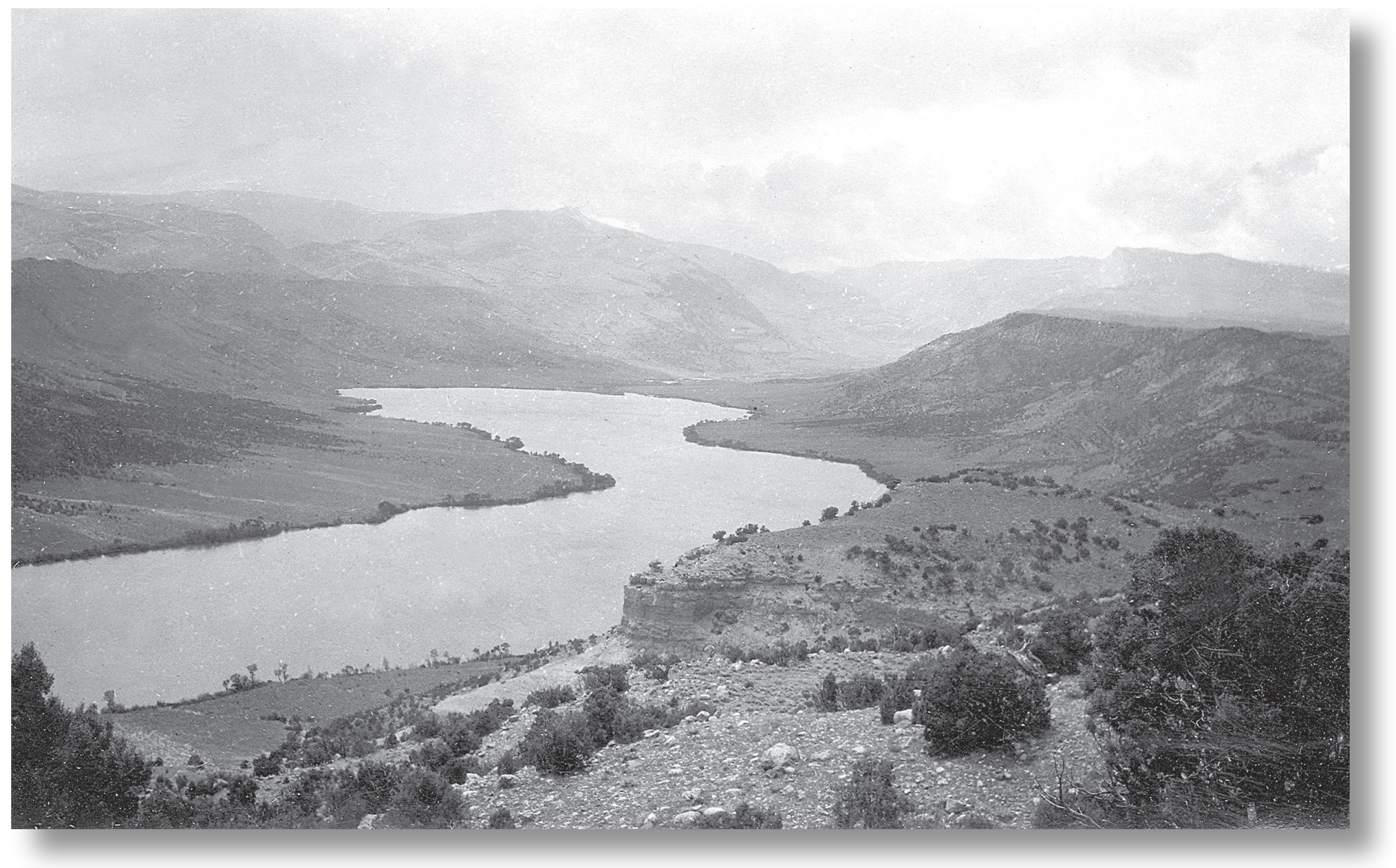




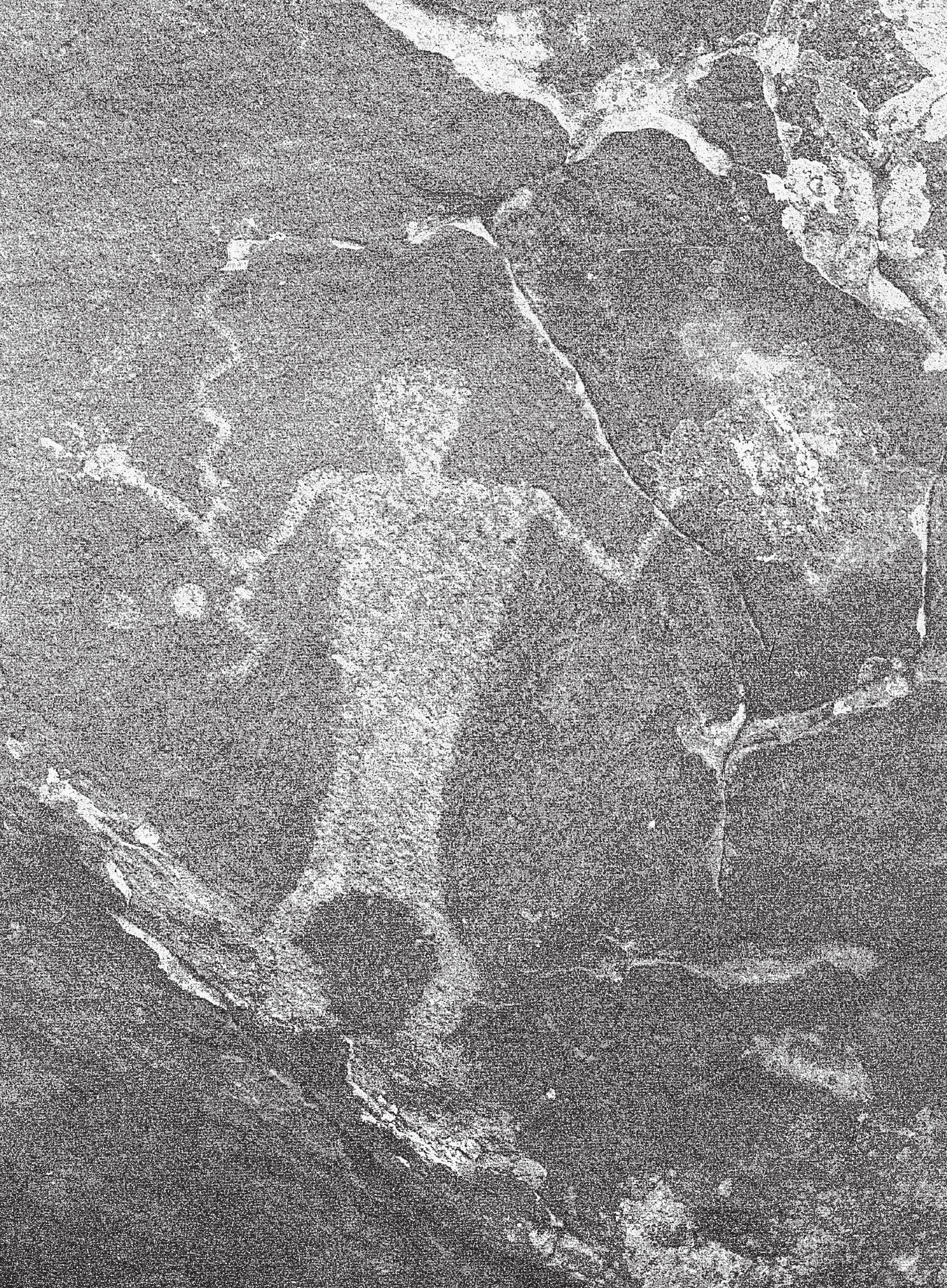






Native American man talking with Major John Wesley Powell during a northern Arizona survey, probably during the 1870s. USGS Photographic Library; photograph by J.K. Hillers.

\section{Navajo Wetlands (Arizona, Colorado, New Mexico)}

USGS wetland scientists from the Fort Collins Science Center continue studying the effectiveness of a constructed wetland built to improve the quality of the wastewater from the community of Piñon on the Navajo Nation for reuse and (or) discharge. In addition to improving water quality, this wetland was designed to provide wildlife habitat that is scarce in the area. This is a cooperative effort of the Navajo Nation, the Indian Health Service, the U.S. Bureau of Reclamation, and the USGS. Besides collecting water-quality data at this site annually since 1999, each year the group has been collecting sediment, vegetation, and macroinvertebrates for bioaccumulation studies of certain chemical elements. Results from this research will provide information on how and when to build additional treatment wetland cells for further development in the Piñon area and in other remote locations within the arid southwest. Sampling was done during July 2003. A report is being prepared. Contact: Joan Thullen, 303-445-2212 or joan_thullen@usgs.govor James Sartoris, 303-445-2230,james_j_sartoris@usgs.gov 


\section{Hualapai Water Monitoring Program (Arizona)}

The USGS Arizona District is cooperating with the Hualapai Tribe by providing technical assistance and on-site training to Hualapai personnel for their water resources monitoring program. USGS personnel trained the Tribal hydrologic technician to collect sediment data and measure streamflow. The Tribal technician also was trained to properly and safely use a cableway located at the Colorado River above the Diamond Creek gage. Contact: Robert J. Hart, 928-556-7137,bhart@usgs.gov; Gregory G. Fisk, 928-556-7225,ggfisk@usgs.gov

\section{Hopi Water Monitoring Program (Arizona)}

The USGS Arizona District continues cooperating with the Hopi Tribe by providing technical assistance and training to Hopi personnel for their surface-water resources monitoring program. Arizona District personnel trained the Tribal hydrologic technician to measure streamflow discharge at Hopi surface-water gages. Contact: Robert J. Hart, 928-556-7137, bhart@usgs.govor Gregory G. Fisk,928-556-7225,ggfisk@usgs.gov

\section{White Mountain Apache Stream-Gaging Cooperation (Arizona)}

The White Mountain Apache Tribe permitted USGS employees to access stream gages on Tribal lands under the terms of an Intergovernmental Agreement. USGS Arizona Water Resources District staff provided training to Tribal staff in water-quality and surface-water data collection techniques. The District staff are providing technical assistance and training on the USGS Automated Data Processing System (ADAPS), which is used to manage hydrologic data. Additional training was provided on Data Collection Platforms. Contact: Christopher Smith, 520-670-6671 ext. 251, cfsmith@usgs.gov

\section{Flood Warning for White Mountain Apache Tribe (Arizona)}

The USGS installed and operated three flood-warning gages to benefit White Mountain Tribal communities. The gages will provide flow information to help the Tribe determine the potential for floods that could harm these communities due to lack of vegetation cover resulting from wildfires. Contact: Christopher Smith, 520-670-6671, ext. 251, cfsmith@usgs.gov

\section{Yavapai-Prescott Water Monitoring Program (Arizona)}

The USGS Arizona Water Resources District continues to cooperate with the YavapaiPrescott Indian Tribe by providing technical assistance and training for the Tribe's waterresources monitoring program. The Tribe began operating and maintaining a crest-stage gage network in FY 2004, and they began their own well-monitoring program in FY 2004 following training with the USGS staff. This activity demonstrates successful collaboration that enhances Tribal capabilities. The USGS also provided technical assistance with well-log interpretations for ground-water wells and with measuring ground-water levels on Yavapai-Prescott lands. This program was designed to assist the Tribe in managing its water resources and to provide water-quality data that the Tribe can use to assess the health of Tribal members and to meet U.S. Environmental Protection Agency water-quality standards. Contact: Robert J. Hart, 928556-7137, bhart@usgs.gov or Gregory G. Fisk, 928-556-7225,ggfisk@usgs.gov 


\section{Hydrologic Information for the Walker River Paiute Tribe (Nevada)}

Each year, during irrigation season, the USGS Nevada Water Resources District collects $\mathrm{pH}$ and conductance measurements for the Walker River Paiute Tribe. The information helps the Tribe in managing its water quality. Contact: Kerry Garcia, 775-887-7659, ktgarcia@usgs.gov

\section{Upper Klamath Lake Water-Quality Conditions (Oregon)}

In 2002, the USGS Oregon Water Resources District Office began a 3-year study to determine the behavioral response of endangered Lost River suckers and shortnose suckers to poor water-quality conditions in Upper Klamath Lake. These fish have cultural significance to the Klamath Tribes and were an historically important food source for Native Americans in the Klamath Basin. As one of the reasonable and prudent alternatives in the 2001 Biological Opinion, the U.S. Fish and Wildlife Service asked the U.S. Bureau of Reclamation to begin a study on the role that "water-quality refuges" in Upper Klamath Lake play in the survival of the endangered suckers during periods when much of the lake is characterized by poor water-quality conditions. The two main parts of the study were (1) to install a network of continuous waterquality monitors to determine the spatial and temporal extent of water-quality refuges in the lake and (2) to track radio-tagged suckers in the lake throughout the summer. The third of three field seasons was completed in 2004. The tracking study was extended for one year while the water quality monitoring studies transition to a long-term monitoring mode. A final report presenting the data collected over all 3 years and what has been learned about water quality in Upper Klamath Lake is in progress. Contact: Tammy Wood,503-251-3255,tmwood@usgs.gov

\section{USGS Technical Assistance to the U.S. Bureau of Indian Affairs (Alaska)}

The USGS continues to provide networking support to the U.S. Bureau of Indian Affairs (BIA). USGS employees provided technical expertise and designs to assist BIA with internal communications after BIA computers were taken off-line. USGS staff began migrating the BIA Alaska network to a new U.S. Department of the Interior system. Contact: Pat Murphy, 650329-4044,pmurphy@noc.usgs.net
Yakutat village near the head of Yakutat Bay, Alaska, 1899. USGS Photographic Library; photograph by G.K. Gilbert.
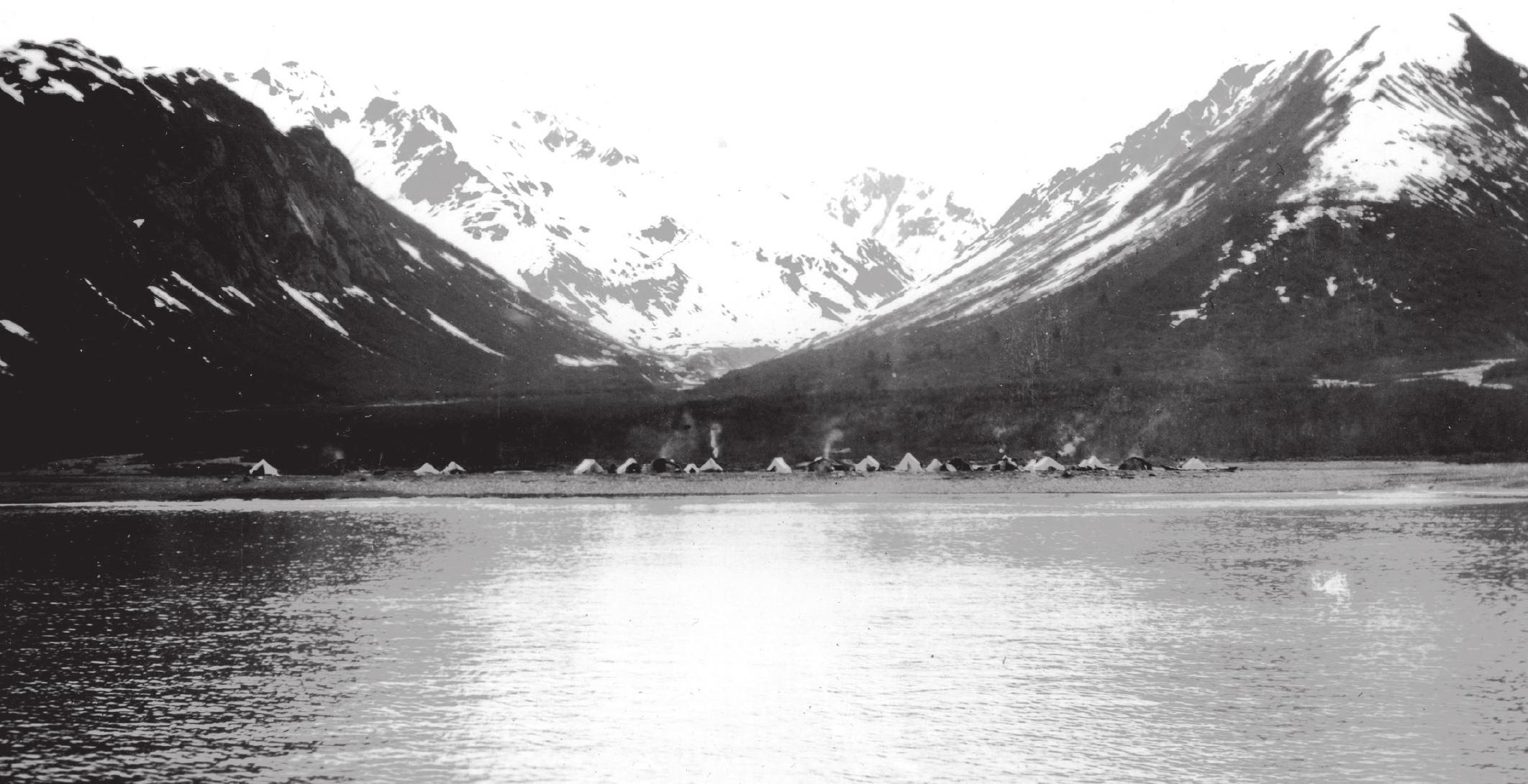


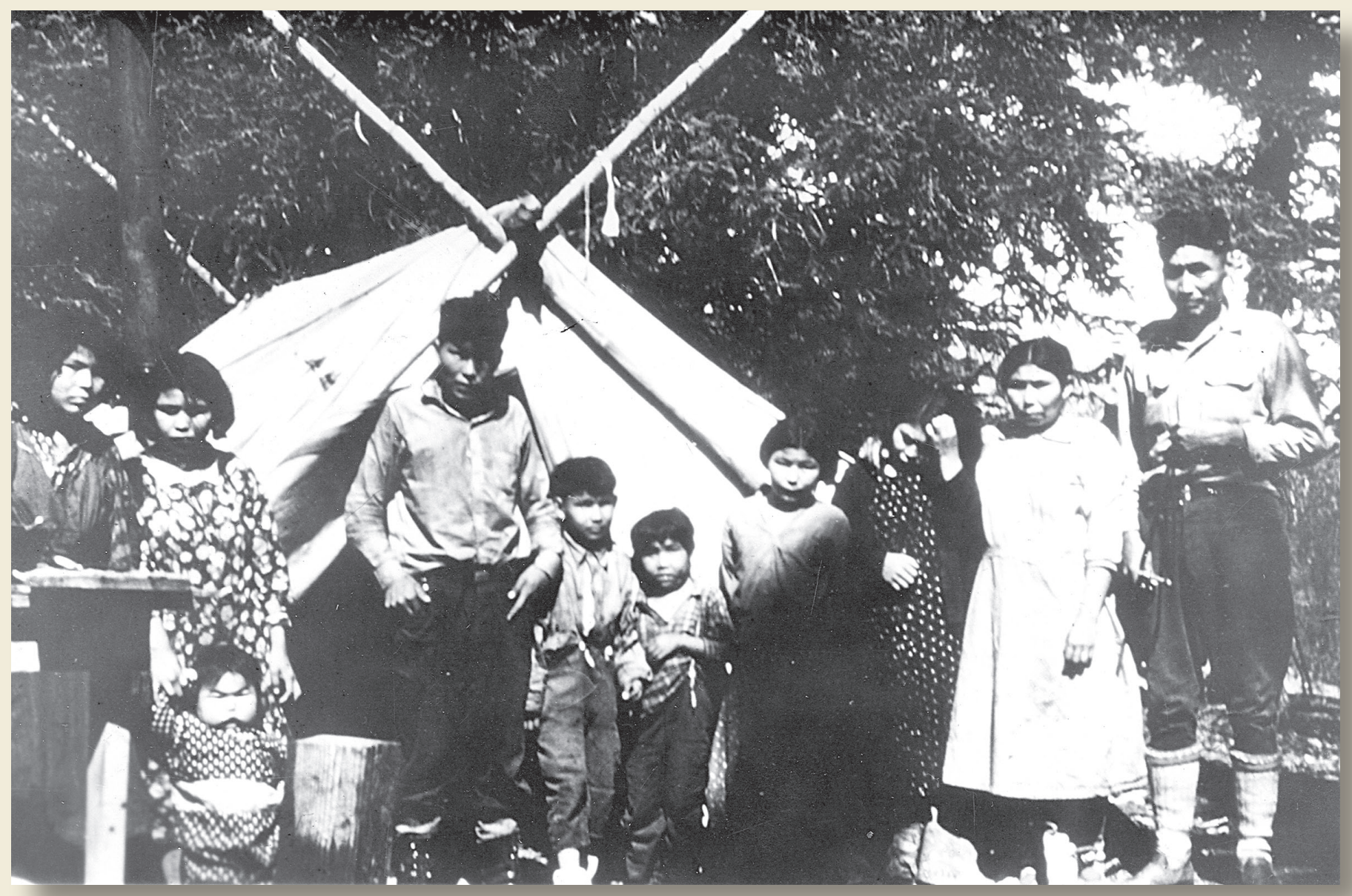

Nabesna Indians, Alaska, August 1944. USGS Photographic Library; photograph by R.F. Black.

\section{Seabird Tissue Archival and Monitoring Project (Alaska)}

In 1998, the Alaska Maritime National Wildlife Refuge (AMNWR), the U.S. Geological Survey Biological Resources Division (USGS), and the National Institute of Standards and Technology (NIST) initiated a joint effort to develop and test protocols for collecting, transporting, processing, and storing seabird eggs collected at AMNWR colonies. Based on this preliminary work, a Seabird Tissue Archival and Monitoring Project (STAMP) was designed to gather information for 100 years. The STAMP was implemented in 1999. To date, this longterm cooperative effort has collected more than 250 common murre, thick-billed murre, and black-legged kittiwake eggs at nine seabird colonies on AMNWR and three seabird colonies on privately owned lands. The processed contents are cryogenically stored at the NIST National Biomonitoring Specimen Bank (NBSB) in Charleston, South Carolina, for current and future studies of pollutants. The project is also analyzing subsamples of the banked tissues to document baseline levels of persistent bioaccumulative contaminants (for example, chlorinated pesticides, PCBs, mercury) at these Alaskan nesting locations. The STAMP routinely collaborates with Alaska Native groups to obtain seabird eggs from subsistence harvests throughout the State. Eggs have been received from the Wildlife and Parks Director, Point Hope IRA (Indian Reorganization Act) Council, Point Hope, Alaska; Maniilaq Association Subsistence Program, Kotzebue, Alaska; Chugach Regional Resources Commission; Seldovia Village Tribe Tribal Environmental Office; Nanwalek Tribal IRA Council, Nanwalek, Alaska; Alaska Sea Otter and Steller Sea Lion Commission; and Tatitlek Village IRA Council, Tatitlek, Alaska. Contact: Geoff York, 907-786-3928, geoff_york@usgs.gov 


\section{Surface-Water Monitoring Stations.}

[USGS Water Resources Districts operated the following surface-water monitoring stations in FY 2004, usually with cooperative funding from each Tribe, the U.S. Bureau of Indian Affairs (BIA), or a third party]

\begin{tabular}{|c|c|}
\hline $\begin{array}{l}\text { Number } \\
\text { of stations }\end{array}$ & Cooperator and contact \\
\hline 2 & $\begin{array}{l}\text { Houlton Band of Maliseet Indians } \\
\text { Contact: Greg Stewart (Maine), 207-622-8205,Ext. 118, gstewart@usgs.gov }\end{array}$ \\
\hline 2 & $\begin{array}{l}\text { Seminole Tribe of Florida \& South Florida Water Management District } \\
\text { (includes two continuous recorders with Tribal nutrient autosamplers) } \\
\text { Contact: Mitch Murray (Florida), 305-717-5827, mmurray@usgs.gov }\end{array}$ \\
\hline 1 & $\begin{array}{l}\text { Keweenaw Bay Indian Community } \\
\text { Contact: Tom Weaver (Michigan), 906-786-0714, tlweaver@usgs.gov }\end{array}$ \\
\hline $\begin{array}{l}2 \\
1 \\
1 \\
1 \\
1 \\
2\end{array}$ & $\begin{array}{l}\text { Sokaogon Chippewa, Mole Lake Band } \\
\text { Bad River Band of Lake Superior Chippewa Indians } \\
\text { Menominee Indian Tribe of Wisconsin } \\
\text { Oneida Tribe of Wisconsin } \\
\text { Stockbridge-Munsee Band of Mohican Indians } \\
\text { Lac du Flambeau Band of Lake Superior Chippewa Indians } \\
\text { Contact: RobWaschbusch (Wisconsin),608-821-3868, rjwaschb@usgs.gov }\end{array}$ \\
\hline $\begin{array}{l}1 \\
3\end{array}$ & $\begin{array}{l}\text { Grand Portage Band of Lake Superior Chippewa } \\
\text { Bois Forte Band of Chippewas, Nett Lake Community } \\
\text { Contact: Kevin Guttormson (Minnesota),218-326-1297, kgguttor@usgs.gov }\end{array}$ \\
\hline
\end{tabular}

Three Affiliated Tribes; Mandan Hidatsa, Arikara

Contact: Steve Robinson (North Dakota), 701-250-7404, smrobins@usgs.gov

Oglala Sioux Tribe

Rosebud Sioux Tribe

Standing Rock Sioux Tribe

Lower Brule Sioux Tribe (crest-stage only)

Oglala Sioux Tribe (crest-stage only)

U.S Bureau of Indian Affairs

Contact: Ralph Teller (South Dakota),605-394-3222,rwteller@usgs.gov

Omaha Tribe of Nebraska and Iowa

Santee Sioux Tribe of Nebraska

Winnebago Tribe of Nebraska

Contact: Phil Soenksen (Nebraska), 402 437-5156,pjsoenks@usgs.gov

Citizen Potawatomi Nation

Contact: Robert Blazs (Oklahoma), 405-810-4419, rblazs@usgs.gov

Blackfeet Nation

Chippewa Cree Tribes of the Rocky Boy's Reservation

Confederated Salish and Kootenai Tribes

Fort Peck Assiniboine and Sioux Tribes

Northern Cheyenne Tribe

U.S. Bureau of Indian Affairs

Contact: Wayne Berkas (Montana), 406-457-5900,wrberkas@usgs.gov 


\begin{tabular}{ll}
\hline $\begin{array}{l}\text { Number } \\
\text { of stations }\end{array}$ & Cooperator and contact \\
\hline 5 & $\begin{array}{l}\text { Joint Business Council of the Northern Arapaho and Eastern Shoshone Tribes } \\
\text { (Wind River Reservation) (annual streamflow-gages) } \\
\text { Joint Business Council of the Northern Arapaho and Eastern Shoshone Tribes } \\
\text { (Wind River Reservation) (seasonal streamflow-gages) }\end{array}$ \\
3 & $\begin{array}{l}\text { Joint Business Council of the Northern Arapaho and Eastern Shoshone Tribes } \\
\text { (Wind River Reservation) (canal rating maintenance) }\end{array}$ \\
4 & $\begin{array}{l}\text { Joint Business Council of the Northern Arapaho and Eastern Shoshone Tribes } \\
\text { (Wind River Reservation) (seasonal canal gaging stations) }\end{array}$ \\
5 & USGS National Streamflow Information Program \\
1 & USGS National Streamflow Information Program (seasonal canal-gaging station) \\
2 & U.S. Bureau of Reclamation \\
1 & U.S. Bureau of Reclamation (seasonal streamflow-gaging station) \\
2 & U.S. Army Corps of Engineers \\
& Contact: Kirk Miller (Wyoming), 307-778-2931, ext. 2716, kmiller@ usgs.gov
\end{tabular}

Southern Ute Indian Tribe

Ute Mountain Ute Tribe

Contact: Bob Boulger (Colorado),970-245-5257, ext.21, rboulger@usgs.gov

Cochiti Pueblo and U.S. Army Corp of Engineers

Isleta Pueblo, New Mexico State Engineer, City of Albuquerque

Navajo Nation, New Mexico State Engineer, U.S. Bureau of Reclamation

San Felipe Pueblo and New Mexico State Engineer

San Ildefonso Pueblo and New Mexico State Engineer

Taos Pueblo, New Mexico State Engineer, and U.S. Bureau of Reclamation

Pueblo of Zuni

Contact: Lynn Miller (New Mexico), 505-830-7908,lkmiller@usgs.gov

Nez Perce Tribe

Shoshone Bannock Tribe and U.S. Bureau of Indian Affairs

Contact: Thomas S. Brennan (Idaho), 208-387-1366, tbrennan@usgs.gov

Pyramid Lake Paiute Tribe

Summit Lake Paiute Tribe

Shoshone-Paiute Tribes

Walker River Paiute Tribe

Contact: Kerry Garcia (Nevada), 775-887-7659, ktgarcia@usgs.gov

\section{Hopi Tribe}

Havasupai Tribe

Pueblo of Zuni

Yavapai-Prescott Indian Tribe (two continuous records and four crest-stage gages)

Tohono O'odham Nation

U.S. Bureau of Indian Affairs \& Peabody Western Coal Co. (Navajo Reservation)

Arizona Department of Water Resources (Navajo Reservation)

U.S. Bureau of Indian Affairs (Navajo Reservation)

U.S. Bureau of Indian Affairs \& Peabody Western Coal Co. (Hopi Reservation)

U.S. Bureau of Indian Affairs (Hualapai Tribe)

U.S. Bureau of Indian Affairs (White Mountain Apache Tribe)

Contact: Christopher Smith (Arizona),520-670-6671, ext.251, cfsmith@usgs.gov 


\begin{tabular}{|c|c|}
\hline $\begin{array}{l}\text { Number } \\
\text { of stations }\end{array}$ & Cooperator and contact \\
\hline 5 & Confederated Tribes of the Umatilla Indian Reservation \\
\hline 4 & Confederated Tribes and Bands of the Yakama Nation \\
\hline 1 & Hoh Indian Tribe \\
\hline 6 & Lummi Nation \\
\hline 1 & Makah Nation \\
\hline 2 & Nisqually Indian Tribe \\
\hline 1 & Puyallup Tribe of Indians \\
\hline 2 & Quileute Tribe \\
\hline 1 & Quinault Indian Nation \\
\hline 1 & Skokomish Tribe of Indians \\
\hline 3 & Spokane Tribe of Indians \\
\hline 1 & Squaxin Island Tribe \\
\hline 4 & The Tulalip Tribes \\
\hline \multirow[t]{2}{*}{2} & U.S. Bureau of Indian Affairs \\
\hline & Contact: Robert Kimbrough (Washington), 253-428-3600, ext. 2608, rakimbro@usgs.gov \\
\hline 12 & Confederated Tribes of the Warm Springs Reservation \\
\hline \multirow[t]{2}{*}{1} & Nez Perce Tribe \\
\hline & Contact: Thomas A. Herrett (Oregon), 503-251-3239, herrett@usgs.gov \\
\hline 1 & Karuk Tribe of California \\
\hline 15 & Pechanga Band and Morongo Band of Mission Indians (wells for monthly depth to water) \\
\hline 3 & Pechanga Band and Morongo Band of Mission Indians (continuous record wells) \\
\hline \multirow[t]{2}{*}{6} & Pechanga Band and Morongo Band of Mission Indians (wells for annual water quality) \\
\hline & Contact: Jim Bowers (California), 760-247-1401, jcbowers@usgs.gov \\
\hline 1 & Cheesh'Na Tribal Council \\
\hline \multirow[t]{2}{*}{1} & Eklutna, Native Village of \\
\hline & Contact: David Meyer(Alaska), 907-786-7141,dfmeyer@usgs.gov \\
\hline
\end{tabular}

\section{Water-Quality Monitoring Stations.}

[USGS Water Resources Districts collected water-quality data at the following sites in FY 2004, usually with cooperative funding from each Tribe]

\begin{tabular}{ll}
\hline $\begin{array}{l}\text { Number } \\
\text { of stations }\end{array}$ & Cooperator and contact \\
\hline 12 & $\begin{array}{l}\text { Northern Cheyenne Tribe; Crow Tribe of Indians (Tongue River) } \\
\text { Fort Peck Assiniboine and Sioux Tribes } \\
\text { Contact: John Lambing (Montana), 406-457-5900, jlambing@ @sgs.gov }\end{array}$ \\
& $\begin{array}{l}\text { Wyoming Department of Environmental Quality (Quarterly water-quality sampling) } \\
\text { Contact: Kirk Miller (Wyoming), 307-778-2931, ext. 2716, kmiller@usgs.gov }\end{array}$ \\
1 & $\begin{array}{l}\text { Pyramid Lake Paiute Tribe } \\
\text { Walker River Paiute Tribe } \\
\text { Contact: Kerry Garcia (Nevada), 775-887-7659, ktgarcia@ usgs.gov }\end{array}$ \\
& $\begin{array}{l}\text { Nooksack Indian Tribe } \\
\text { Contact: Robert Kimbrough (Washington), 253-428-3600, ext. 2608, rakimbro@usgs.gov }\end{array}$ \\
& $\begin{array}{l}\text { Cheesh'Na Tribal Council } \\
\text { Eklutna Native Village } \\
\text { Contact: Dave Meyer (Alaska), 907-876-7141, dfmeyer@usgs.gov }\end{array}$ \\
\hline
\end{tabular}




\section{Ground-Water Monitoring Stations.}

[USGS Water Resources Districts operated the following ground-water monitoring stations in FY 2004, usually with cooperative funding from each Tribe]

\begin{tabular}{|c|c|}
\hline $\begin{array}{l}\text { Number } \\
\text { of stations }\end{array}$ & Cooperator and contact \\
\hline $\begin{array}{l}1 \\
9\end{array}$ & $\begin{array}{l}\text { Collection of Basic Records program (observation well located on Kaibab Band of Paiute Indians Reservation) } \\
\text { Bureau of Indian Affairs (Navajo Nation, Hopi Tribe, White Mountain Apache Tribe) } \\
\text { Contact: Christopher Smith (Arizona), 520-670-6671, ext. 251, cfsmith@ usgs.gov }\end{array}$ \\
\hline 3 & $\begin{array}{l}\text { Confederated Tribes of the Umatilla Indian Reservation (continuous recording in wells) } \\
\text { Contact: Terrence Conlon (Oregon, USGS),503-251-3232, tdconlon@ usgs.govor } \\
\text { Kate Ely(Umatilla), 541-966-2427, kateely@ctuir.com }\end{array}$ \\
\hline $\begin{array}{l}1 \\
4\end{array}$ & $\begin{array}{l}\text { Pyramid Lake Paiute Tribe } \\
\text { Walker River Paiute Tribe } \\
\text { Contact: Kerry Garcia (Nevada), 775-887-7659, ktgarcia@usgs.gov }\end{array}$ \\
\hline
\end{tabular}

\section{Lake-Stage Monitoring Stations.}

[USGS Water Resources Districts operated the following lake-stage monitoring stations to determine lake levels in FY 2004, usually with cooperative funding from each Tribe]

\begin{tabular}{ll}
\hline $\begin{array}{l}\text { Number } \\
\text { of stations }\end{array}$ & Cooperator and contact \\
\hline 1 & $\begin{array}{l}\text { Bois Forte Band of Chippewa, Nett Lake Community } \\
\text { Contact: Kevin Guttormson (Minnesota), 218-326-1297, kgguttor@usgs.gov }\end{array}$ \\
& $\begin{array}{l}\text { Prairie Island Indian Community } \\
\text { Contact: Don Hansen (Minnesota), 763-783-3250, dshansen@usgs.gov }\end{array}$ \\
& $\begin{array}{l}\text { Walker River Paiute Tribe } \\
\text { Pyramid Lake Paiute Tribe } \\
\text { Contact: Kerry Garcia (Nevada), 775-887-7659, ktgarcia@usgs.gov }\end{array}$ \\
& $\begin{array}{l}\text { The Tulalip Tribes } \\
\text { Contact: } \text { Robert Kimbrough (Washington), 253-428-3600, ext. 2608, rakimbro@usgs.gov }\end{array}$
\end{tabular}

\section{Sediment-Monitoring Stations.}

[USGS Water Resources Districts operated the following sediment-monitoring stations in FY 2004, usually with cooperative funding from each Tribe]

\begin{tabular}{ll}
\hline $\begin{array}{l}\text { Number } \\
\text { of stations }\end{array}$ & Cooperator and contact \\
\hline 3 & $\begin{array}{l}\text { Hopi Tribe } \\
\text { Pueblo of Zuni } \\
\text { Contact: } \text { Christopher Smith (Arizona), 520-670-6671, ext. 251, cfsmith@usgs.gov }\end{array}$ \\
\hline
\end{tabular}




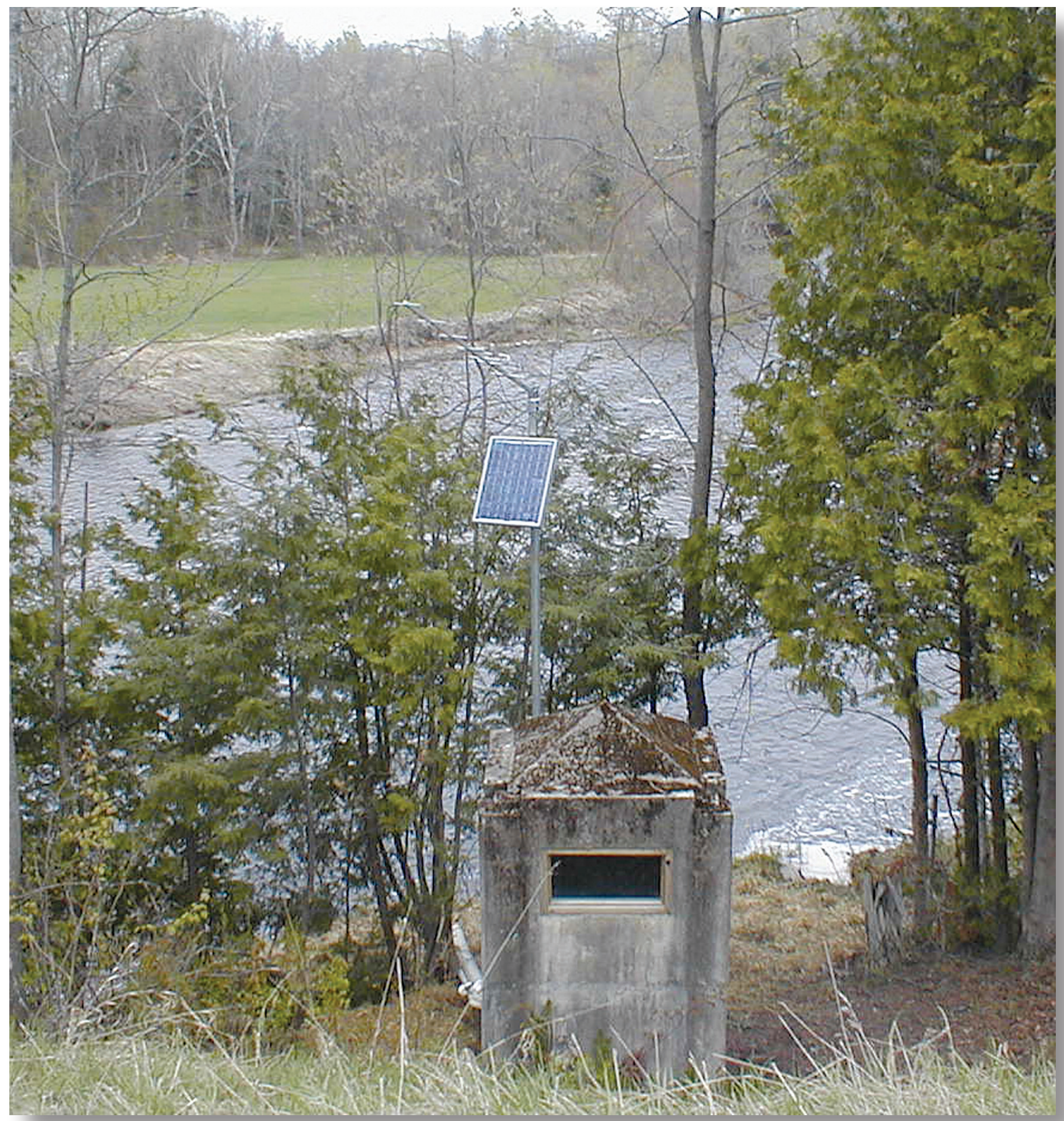

Real-time, continuous water-quality, river-flow gage on the Meduxnekeag River, Houlton, Maine; operated in collaboration with the Houlton Band of Maliseet Indians. Photograph by Andy Cloutier. 


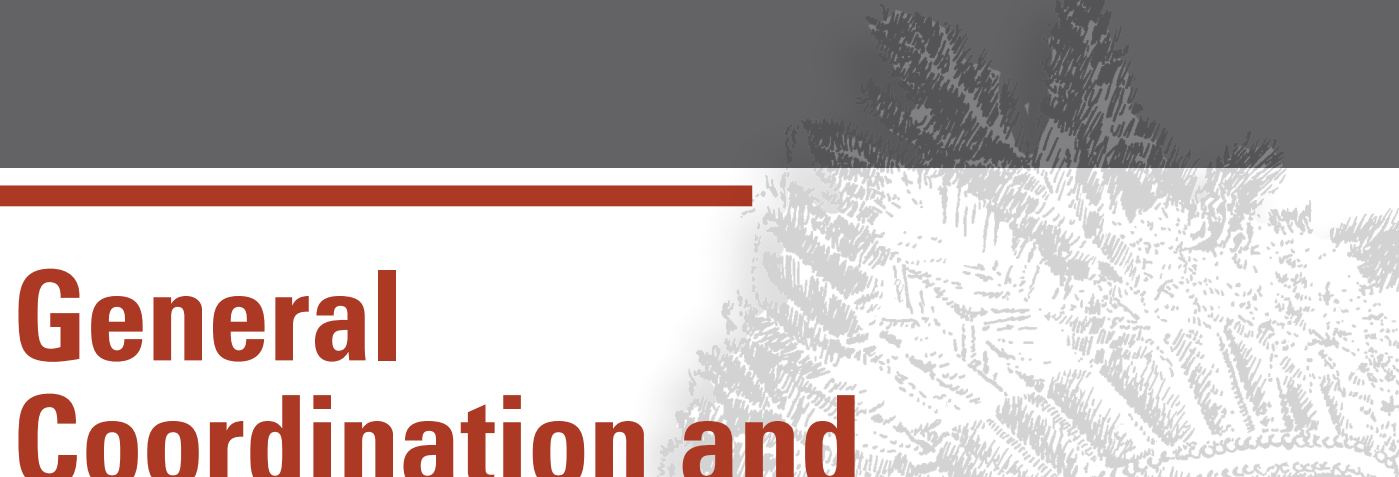
Policy Activities

$$
+\infty
$$
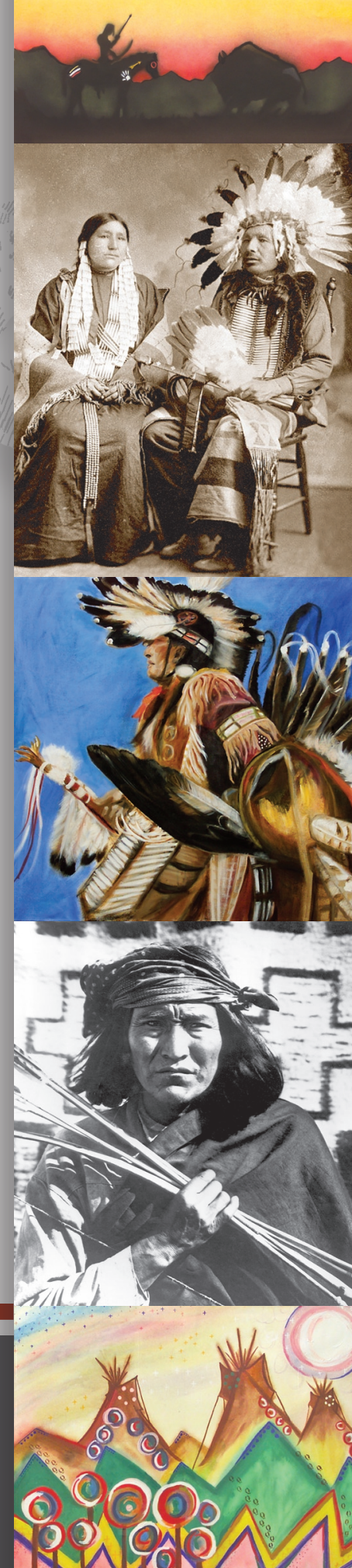




Central part of Cliff Palace, Mesa Verde National Park, Colorado. USGS Photographic Library; photograph taken in 1911 by R.W. Berry. 


\section{General Coordination and Policy Activities}

\section{Geographic Information Systems Training Coordination}

In cooperation with the USGS (EROS Data Center), the Federal Geographic Data Committee and National States GIS Council plan and develop Tribal, Federal, State, and local workshops, including the annual Tribal College Forum. The workshops and the Forum offer the Tribes an overview of the National Spatial Data Infrastructure and information to assist them with their planning processes, development of data sets, and data sharing. Contact: Bonnie Gallahan, 703-648-6084, bgallahan@usgs.gov

\section{Cooperative Training with Department of Homeland Security and Federal Emergency Management Agency}

The Federal Geographic Data Committee (FGDC), through its Memorandum of Understanding (MOU) with the Department of Homeland Security and the Federal Emergency Management Agency, offers several classes for Tribal entities on topics such as Tribal Framework for Emergency Preparedness; Emergency Operations for Tribal Governments; Introduction to Basic HAZUS (Hazards Use)-Multi Hazards; Intermediate Basic HAZUS-Multi Hazards; and Mitigation for Tribal Officials. All courses include overviews of the National Spatial Data Infrastructure, CAP, Geospatial One Stop, and The National Map. Contact: Bonnie Gallahan, 703-648-6084,bgallahan@usgs.gov

\section{Rural Geospatial Innovations in America (RGIS)}

The Federal Geographic Data Committee (FGDC), through its Memorandum of Understanding (MOU) with Rural Geospatial Innovations in America (RGIS), will assist Federal, State, Tribal, and local entities in implementing advanced geospatial information technologies to improve the quality of life, environmental health, and economics of rural communities. Activities covered by the MOU include: technical assistance to Tribal Colleges and Universities in developing and managing geographic information systems, implementing training programs on the National Spatial Data Infrastructure, Geospatial One Stop, The National Map, and short courses and university curricula on advanced spatial analysis for decision-making processes. Contact: Bonnie Gallahan, 703-648-6084,bgallahan@usgs.gov 


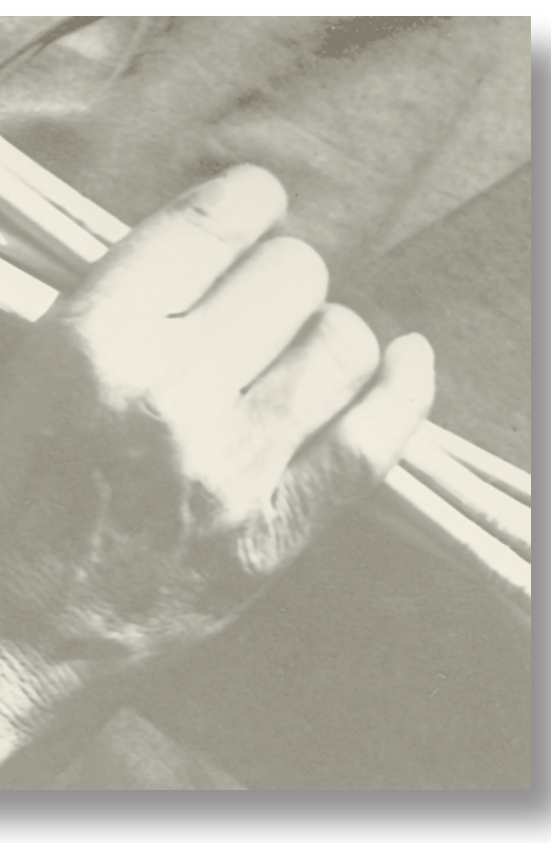

\section{USGS Contributes to Native American Fish and Wildlife Society Conferences}

The USGS participated in the national conference of the Native American Fish and Wildlife Society (NAFWS) as well as several of its regional conferences.

National Conference: At the annual national meeting of the NAFWS in Jackson Hole, Wyoming, May 4-6, 2004, two USGS scientists were invited to present information on USGS studies of transmissible wildlife diseases. Many Tribes were represented at the national meeting where USGS scientists made presentations on chronic wasting disease and West Nile Virus. Both of these diseases have recently become very important to Tribal communities. The national meeting of this organization provides a forum to share information on many important technical subjects. Contact: Emi Saito, 608-270-2456, esaito@usgs.gov

Pacific Region: A Staff Biologist with the USGS National Wildlife Health Center (NWHC) was invited to present information at the NAFWS Pacific Region Conference held in Ocean Shores, Washington, from October 13-15, 2004. The presentations were on chronic wasting disease (CWD) ecology, CWD surveillance, and West Nile Virus epidemiology. Indian Nations in attendance included Quinault, Quileute, Blackfeet, Warm Springs, and Confederated Salish and Kootenai. Contact: Rex Sohn, 608-270-2447, rsohn@usgs.gov

Great Lakes Region: Two USGS scientists attended the Native American Fish and Wildlife Society's conference for the Great Lakes Region on September 15, 2004. The meeting was hosted by the Lac du Flambeau Band of the Ojibwe. Hands-on training was provided by NAFWS and USGS on proper removal and processing techniques for sampling deer for CWD. Contact: Bryan Richards, 608-270-2485, brichards@usgs.gov

Pacific Region: The Pacific Region Conference of the NAFWS was held in Polson, Montana, on November 2, 2004. A USGS biologist presented information on the biology of CWD to attendees. Contact: Bryan Richards, 608-270-2485, brichards@usgs.gov

\section{Haudenosaunee Environmental Task Force}

Representatives of the USGS New York Water Science Center were honored to speak at the Onondaga Nation Longhouse in May 2004. The talk was part of the agenda for the Haudenosaunee Environmental Task Force meeting. The Haudenosaunee Environmental Task Force includes delegates from the Cayuga, Anishinabe (Mohawk), Oneida, Onondaga, Seneca, and Tuscarora Nations. A USGS hydrologist presented past results and plans for continuing work on the hydrogeology of the Onondaga Valley. This project focuses on the movement of brine through the aquifer system in the valley and associated hydrogeologic phenomena, such as the development of mudboils and landslide activity in the valley. Current partners on this project are the U.S. Environmental Protection Agency and the Onondaga County (New York) Soil and Water Conservation District. Contact: Bill Kappel,607-266-0217, ext. 3013, wkappel@usgs.gov

\section{Biological Information for Committees of the Great Lakes Fishery Commission}

The Great Lakes Fishery Commission has established inter-agency committees to coordinate fishery resource management in individual lakes. The USGS Great Lakes Science Center and Native American organizations, such as the Chippewa Ottawa Resource Authority and the Great Lakes Indian Fish \& Wildlife Commission, are represented on the committees for lakes Superior, Michigan, and Huron. To assist Tribal and State fishery management agencies in assessing the success of fish restoration efforts, USGS and Tribal scientists report annually on the status of lake trout rehabilitation and important prey fishes in lakes Superior, Michigan, and Huron. In addition, for the Lake Superior Committee, the USGS provided data and technical assistance. Contact: Sandra Morrison, 734-214-9391, smorrison@usgs.gov

(Facing Page) Historical image from USGS Photographic Library. Date and photographer unknown. 



\section{Coordination with Tribal Organizations in Michigan}

USGS staff attended quarterly Michigan Tribal Environmental Group (MTEG) meetings. The Michigan Tribes, the Inter-Tribal Council of Michigan, the U.S. Environmental Protection Agency (EPA) Region 5, the USGS, the U.S. Department of Agriculture, the State of Michigan, and other groups and agencies are represented in MTEG. MTEG meetings provide a forum for environmental issues pertinent to Michigan Tribes. The USGS also participates in quarterly Multi-Federal Agency Memorandum of Understanding (MOU) meetings sponsored by the Midwest Region of the U.S. Bureau of Indian Affairs (BIA). Federal agencies participating in the MOU workgroup include the BIA, the USGS, the Indian Health Service, the U.S. Army Corps of Engineers, and the EPA, which meet to cooperatively plan and coordinate Federal-Tribal activities in EPA's Region 5. Contact: Tom Weaver, 906-786-0714,tlweaver@usgs.gov

\section{Oceti Sakowin Experience (South Dakota)}

As part of the commemoration of the Lewis and Clark Expedition, a Signature Event was hosted in August 2004 by the Alliance of Tribal Tourism Advocates along the Missouri River in Oacoma and Chamberlain, South Dakota. The Oceti Sakowin (Seven Council Fires) experience was a nationally recognized event that featured activities showcasing the American Indian perspective of the Lewis and Clark Expedition. The National Center for Earth Resources Observation and Science (EROS) staff set up two exhibit booths where they greeted visitors. The exhibits included a USGS Lewis and Clark display and a display of satellite images showing landscape changes of key points along the expedition route from St. Louis, Missouri, to Ft. Clatsop, Oregon. The two booths also featured a log line, sextant, and river sediment examples to illustrate past and present scientific measurements. In addition, EROS staff displayed a series of Blue Cloud Abbey historical Native American photographs. Contact: Mark Barber, 605-594-6176barber@usgs.govor Carrie Jucht, 605-594-6800 cjucht@usgs.gov

\section{Sicangu Lakota Art Benefits the USGS (South Dakota)}

The covers of the USGS Annual Report on Activities Related to Native Americans and Alaska Natives are designed to be meaningful, blending Native American, USGS, and natural resource imagery into an attractive, meaningful visual presentation. In FY 2004, the USGS requested art submissions from Sicangu Lakota (Rosebud Sioux) educational sources including St. Francis High School, Todd County High School, and Sinte Gleska University for artwork to be used on the covers of the USGS report. The submissions ranged from beadwork, drawings, and paintings to airbrushed work. Representatives of the Tribe selected the works to be used in the USGS report. Contact: Gene Napier, 605-594-6088,napier@usgs.gov

\section{Computer Donations to South Dakota Tribes}

The USGS donated more than 200 computers to Rosebud, Crow Creek, and Lower Brule Tribes. Computers were also donated to American Indian Services in Sioux Falls, South Dakota. These excess computers were used in Tribal Schools, Tribal Offices, and other places on the reservations. These donations help assure more Native Americans have access to computers. USGS donations are made several times each year. Contact: Gene Napier, 605-5946088,napier@usgs.govor Terry Pfannenstein 605-594-6146,pfan@usgs.gov 


\section{Sinte Gleska University-USGS Agreement (South Dakota)}

The relationship between Sinte Gleska University (SGU), formalized by a Memorandum of Understanding (MOU), continues to produce results shown elsewhere in this report under separate project descriptions. In 2004, representatives of SGU and the USGS communicated frequently about partnership activities, general partnership coordination, and potential new projects under the MOU. Contact: Gene Napier,605-594-6088,napier@usgs.gov

\section{Ground Water in the Española Basin (New Mexico)}

The Española basin is the primary source of water for several Pueblos and for the cities of Santa Fe and Los Alamos, New Mexico. Scientific knowledge of the geologic controls on ground-water flow, storage, and contamination is needed to inform water management decisions, especially during drought conditions. The USGS hosted a workshop in March 2003 in Santa Fe, New Mexico, for geophysicists, geologists, hydrologists, and water resource managers from various Federal, Pueblo, State, and local government agencies and academia. The workshop provided a forum for the scientists to exchange information, develop mutual goals, report progress to technical communities, and establish a working relationship with decision-makers. Annual workshops hosted in 2002, 2003, and 2004 in Santa Fe, New Mexico, have encouraged communication among scientists working in the Española basin and have communicated results of their studies to the 85-100 attendees, several of whom were members of Pueblo Nations. Workshop information can be found at http://climchange.cr.usgs.gov/ebtag. Contact: Tien Grauch, 303236-1393,tien@usgs.govor MarkHudson,303-236-7446,mhudson@usgs.gov

\section{Sonoran Desert Ecology (Arizona)}

The Sonoran Desert Research Station of the USGS Southwest Biological Science Center is cooperating with the University of Arizona and the National Park Service Natural Resource Information Division in creating an educational module, "Views of the National Parks," about the Sonoran Desert Ecosystem. This module will be available online and on CDs for use by teachers and the public. A member of the Hia-Ced O'odham Tribe provided a valuable perspective on the Native American connection to the Sonoran Desert. This perspective is an important part of the educational experience being presented through this program. Contact: Bill Halvorson, 520-621-1174, bill_halvorson@usgs.gov

\section{FY 2004 U.S. Department of the Interior High Priority Data Program Coordination (Oregon and Washington)}

The USGS Northwest Geographic Science Team hosted the FY 2004 Oregon/Washington Department of the Interior (DOI) High Priority Data Program Coordination Meeting in Portland, Oregon, in December 2003. The regional representatives of DOI agencies in Oregon and Washington met to determine priorities for USGS digital data collection for FY 2004. The U.S. Bureau of Indian Affairs (BIA) was represented by staff from the Portland BIA office. The DOI representatives selected the acquisition of LiDAR elevation data, along both sides of the Lower Columbia River from Bonneville Dam to the mouth of the river, as their top priority for USGS data collection. LiDAR data acquisition will be conducted during the winter of 2004-05, with distribution to the DOI agencies in the summer of 2005. The LiDAR data will also be made available online through The National Map. Contact: NancyTubbs, 503-251-3210,ntubbs@usgs.gov 


\section{U.S. Bureau of Indian Affairs Annual Pacific Northwest GIS Conference (Idaho, Washington, Oregon)}

In August 2004, the USGS State Mapping Liaisons for Idaho, Oregon, and Washington participated in the U.S. Bureau of Indian Affairs Annual Pacific Northwest GIS Conference held in Lincoln City, Oregon. The three liaisons made a joint presentation on specific partnership activities with the Coeur d'Alene Tribe as well as The National Map activities and partnerships in Idaho, Oregon, and Washington. They also had the opportunity to listen to GIS presentations and network with representatives from several Tribes in the Pacific Northwest, including the Quinault Indian Nation, the Confederated Tribes of the Warm Springs Reservation, the Makah Nation, the Suquamish Tribe, and the Confederated Tribes and Bands of the Yakama Nation. Contact: Nancy Tubbs, 503-251-3210,ntubbs@usgs.gov

\section{Collaboration with the Torres Martinez Desert Cahuilla Indians on Restoration of the Salton Sea (California)}

The Salton Sea Science Office of the USGS participates with a consortium of Federal, State, and local agencies and the Torres Martinez Tribe in activities related to restoration of the Salton Sea ecosystem in California. The Tribe is a major landowner around the Sea, and Tribal representatives participate on the Salton Sea Authority and the Science Advisory Committee. They are interested in the economic and recreational future of the region, and specifically with issues such as air quality, watershed contamination, and wetlands and wildlife enhancement. Contact: Doug Barnum, 760-777-1564,Doug_Barnum@usgs.gov

\section{Alaska Native Corporations Join the Alaska Geographic Data Committee}

The Bristol Bay Native Corporation (BBNC) and the NANA Regional Corporation became official members of the Alaska Geographic Data Committee (AGDC). These two Native corporations were created under the Alaska Native Claims Settlement Act of 1971. The AGDC is a consortium of Federal agencies, State and local governments, Native entities, and academia working together to build a solid geospatial data foundation for the people of Alaska. The AGDC is co-chaired by the USGS. The objective of the AGDC is to provide a forum for the coordination of spatial data development projects, development of coordinated methodologies for implementing standards and policies, and review and response to Federal Geographic Data Committee initiatives. These memberships will broaden Native participation in the activities of the AGDC. Contact: AC Brown,907-786-7002, ACBrown2@usgs.gov 


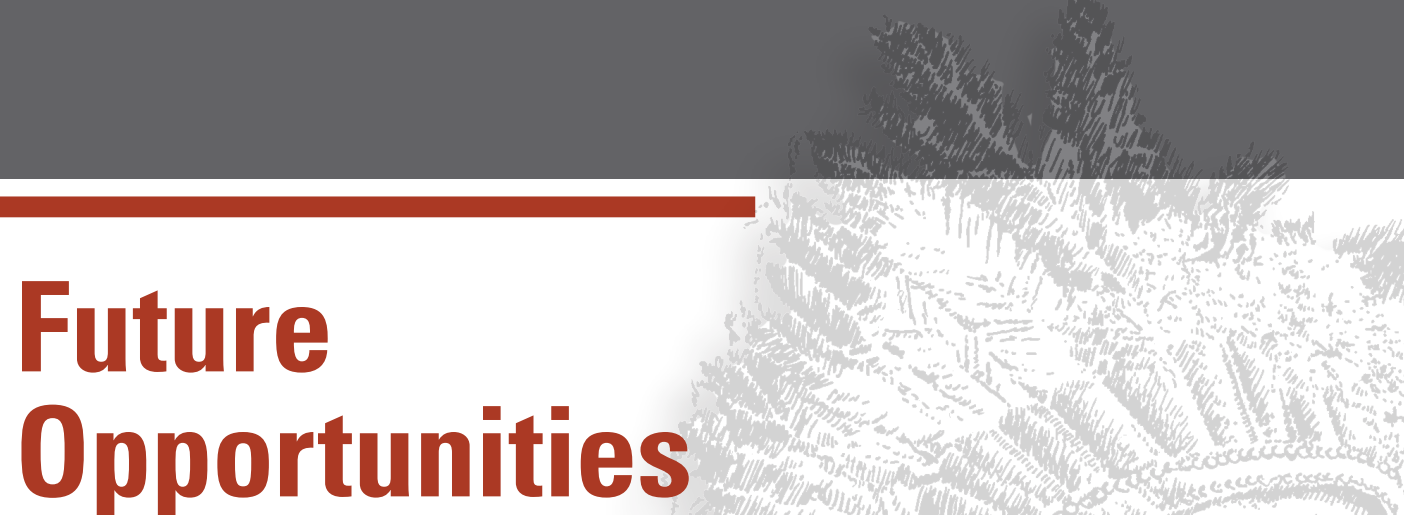

. 


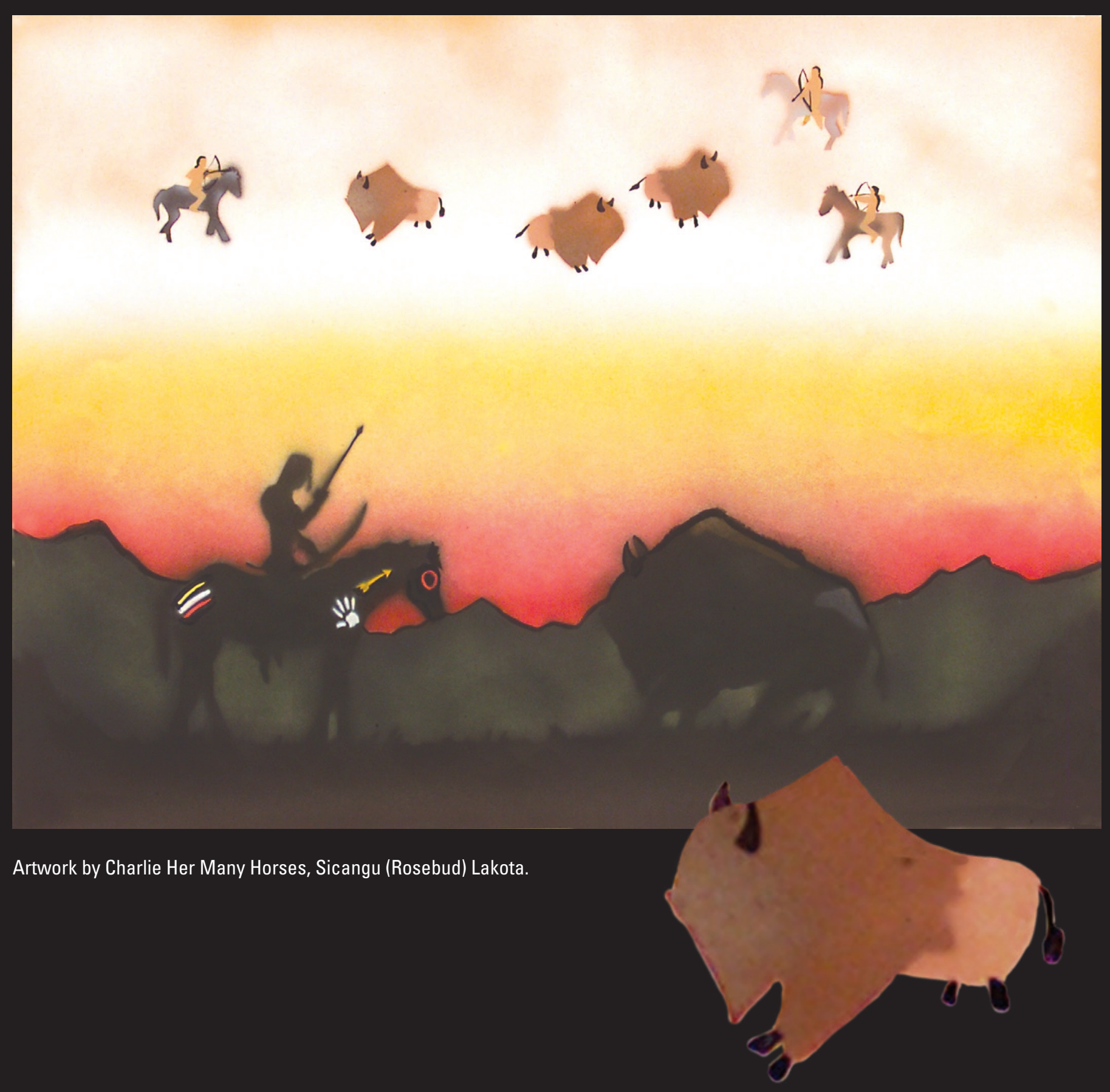




\section{Future Opportunities}

\section{United Sioux Tribes Memorandum of Understanding with the USGS}

The United Sioux Tribes Development Corporation (USTDC) and the USGS wrote a Memorandum of Understanding (MOU) that was signed by both parties in FY 2005. The USTDC represents the 11 Sioux Tribal governments. Each elected Tribal Chairman represents his or her reservation on the USTDC Board. The purpose of the agreement is to establish a working relationship for developing a Geographic Information System, improve information technology, partner on natural science research and training, and share science data and facilities. The agreement is a means of improving Tribal resource management by facilitating Tribal use of USGS data in Tribal management decisions. The agreement is an example of USGS implementation of the government-to-government relations between Tribes and the Federal government. Contact: Gene Napier,605-594-6088, enapier@usgs.gov or Clifton Skye (USTSC), 605-521-9396,CwSkye@aol.com

\section{Geographic Information in the Four Corners Region}

The USGS is interested in working with Tribes in the Four Corners region (Utah, Colorado, New Mexico, and Arizona) to coordinate and mutually support geospatial activities. Geographic Information Systems (GIS) data development and geospatial coordination continues with Utah Native American Tribal organizations, as requested and needed. A Statewide meeting with all the GIS/geospatial representatives is being planned for 2006. Contact: David M. Vincent,801-975-3435,dmvincent@usgs.gov

\section{Landscape Change, Grassland Health, and Bark Beetle Infestation on San Carlos Reservation in East Central Arizona}

The USGS Southwest Geographic Science Team is working closely with officials of the San Carlos Apache Tribe to develop a wide-ranging study of tribal lands. This cooperative study is intended to utilize the resources of the USGS, the San Carlos Tribe, and the U.S. Bureau of Indian Affairs. Easily accessible from the Phoenix, Arizona, metropolitan area, the San Carlos Apache Indian Reservation is characterized by a variety of geological, historical, cultural, and recreational activities. Tribal leaders have expressed their need for remotely sensed data products and technology to assist with ecosystem management plans and wise utilization of their resources. Tribal managers want to (1) evaluate land cover changes using historic and current data, (2) evaluate grassland health and invasive grasses, particularly cheat grass, for better rangeland management, and (3) monitor tree mortality due to bark beetle infestation for better forestry management. The Tribe also wants to improve its capabilities in producing remotely sensed data products that are customized to specific Tribal needs. This study will use remotely sensed satellite data at a variety of spatial and temporal resolutions to develop mapping products and GIS data for the San Carlos Apache to use in managing their lands. In addition to producing the desired products, the methods used will provide training into the best satellite data and methodologies for vegetation mapping and monitoring of grassland health and bark beetle infestation. This project includes a technology transfer component to be developed by the Southwest Geographic Science Team in concert with Tribal personnel. This part of the project will assist the Tribe in acquiring its own hardware and software and provide training by the USGS in remote sensing and in the use of selected image processing software. Contact: Ed Pfeifer (USGS), 520-670-5019, epfiefer@usgs.gov or Dee Randall, (San Carlos Apache Tribe), 928-475-2326

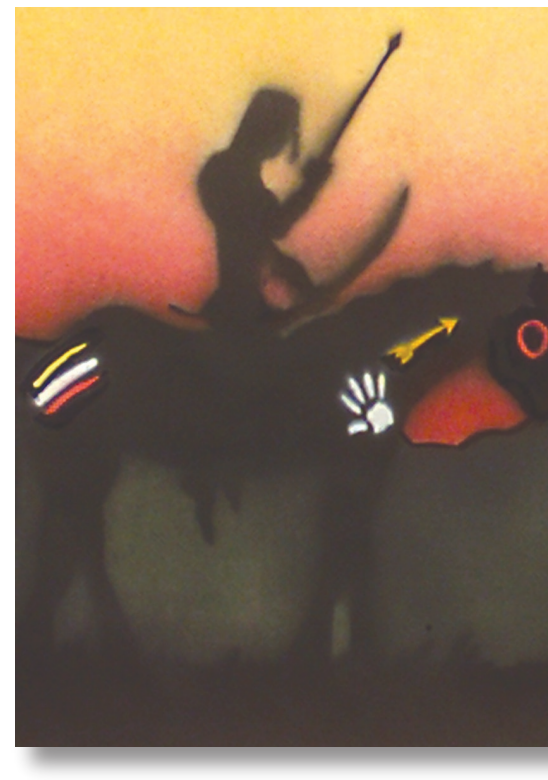




\section{Deschutes River Basin Conservation Planning and The National Map (Oregon)}

In November 2004, the USGS Northwest Geographic Science Team (NGST) staff participated in a Deschutes River basin conservation planning meeting held on the Warm Springs Indian Reservation. Participants included Warm Springs Tribal members; representatives from Warm Springs Geo Visions, a Warm Springs Tribal Geographic Information Systems company; the U.S. Natural Resources Conservation Service; the U.S. Bureau of Land Management; and county-level representatives. The Deschutes River basin includes parts of six central Oregon counties, as well as the Warm Springs Reservation. This group has come together to determine what geospatial data layers are needed for the basin conservation-planning process. Geospatial data will contribute to the conservation planning decision-making process, with the goal being to construct a conservation plan that will make 80 percent of the land area in the basin stable within the next 8 years. During 2005, the NGST will work with other members of the group, including the Warm Springs Tribe, to produce geospatial data layers for the basin. This cooperative effort will build partnerships that benefit this conservation-planning project and help to implement The National Map. Contact: Nancy Tubbs, 503-251-3210,ntubbs@usgs.gov

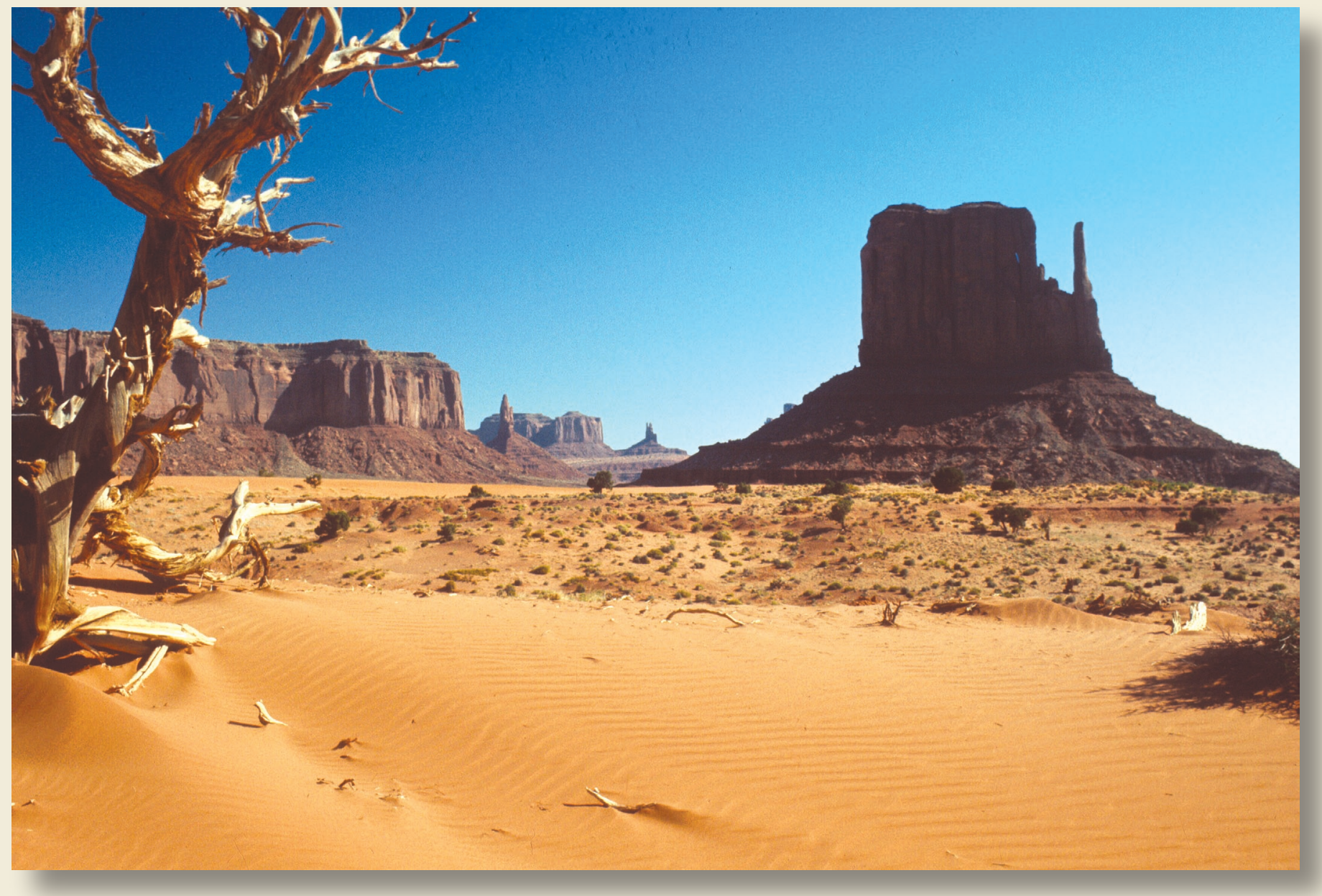

Monument Valley, Navajo Indian Reservation, northern Arizona. USGS Photographic Library; photograph taken in 1972 by E.D. McKee. 


\section{USGS Contacts}

The U.S. Geological Survey has an American Indian/Alaska Native Coordinating Team to establish policy and to coordinate USGS activities. Please contact any of the individuals listed below for more information or to discuss questions or concerns.

\section{Director's Office: Susan Marcus}

MS 104, 12201 Sunrise Valley Dr., Reston, Virginia 20192

703-648-4437; fax 703-648-5470; smarcus@usgs.gov

\section{Eastern Region: Gayle Sisler}

MS 150, 12201 Sunrise Valley Dr., Reston, Virginia 20192

703-648-4412; fax 703-648-4588; gsisler@usgs.gov

\section{Central Region: Gene Napier}

EROS Data Center, Mundt Federal Center, Sioux Falls, South Dakota 57198 605-594-6088; fax 605-594-6154; enapier@usgs.gov

\section{Western Region: Cyndee Matus}

909 First Ave., Suite 700, Seattle, Washington 98104-1055

206-220-4547; fax 206-220-4570; cyndee_matus@usgs.gov

\section{Biological Resources: Kevin Whalen}

MS 301, 12201 Sunrise Valley Dr., Reston, Virginia 20192

703-648-4062; fax 703-648-4238; kwhalen@usgs.gov

\section{Geology: Sharon Swanson}

MS 910, 12201 Sunrise Valley Dr., Reston, Virginia 20192

703-648-6453; fax 703-648-6057; smswanson@usgs.gov

\section{Geography: Gene Napier}

EROS Data Center, Mundt Federal Center, Sioux Falls, South Dakota 57198

605-594-6088; fax 605-594-6154; enapier@usgs.gov

\section{Geographic Information: Bonnie Gallahan}

MS 590, 12201 Sunrise Valley Dr., Reston, Virginia 20192

703-648-6084; fax 703-648-5755; bgallahan@usgs.gov

\section{Water Resources: Glenn Patterson}

MS 409, 12201 Sunrise Valley Dr., Reston, Virginia 20192

703-648-6876; fax 703-648-7031; gpatter@usgs.gov

Office of Equal Opportunity: John Szemraj

MS 602, 12201 Sunrise Valley Dr., Reston, Virginia 20192

703-648-7011; fax 703-648-4445; jszemraj@usgs.gov

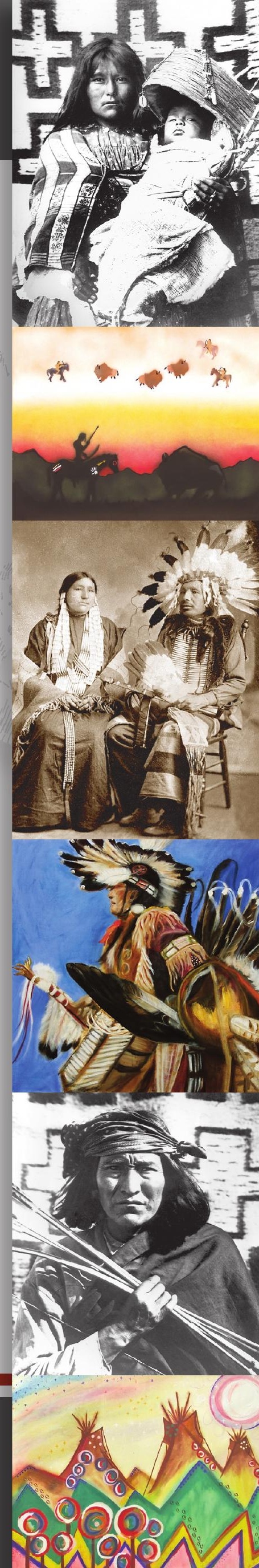


Many of the historical images in this book are from the U.S. Geological Survey Library Earth Science Photographic Library Archive. These images and many others can be downloaded free of charge at :

http://libraryphoto.cr.usgs.gov/

Edited by F. Craig Brunstein, Denver Publishing Service Center

Publication design and digital layout by Carol Quesenberry, Denver Publishing Service Center

Original drawings by Carol Quesenberry, Denver Publishing Service Center

Assistance in publication production provided by Sharon Powers and Joy Monson, Denver Publishing Service Center 


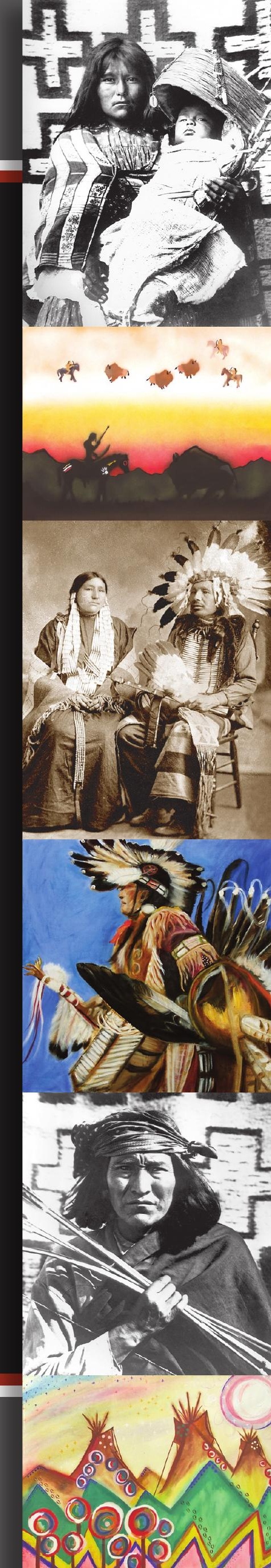




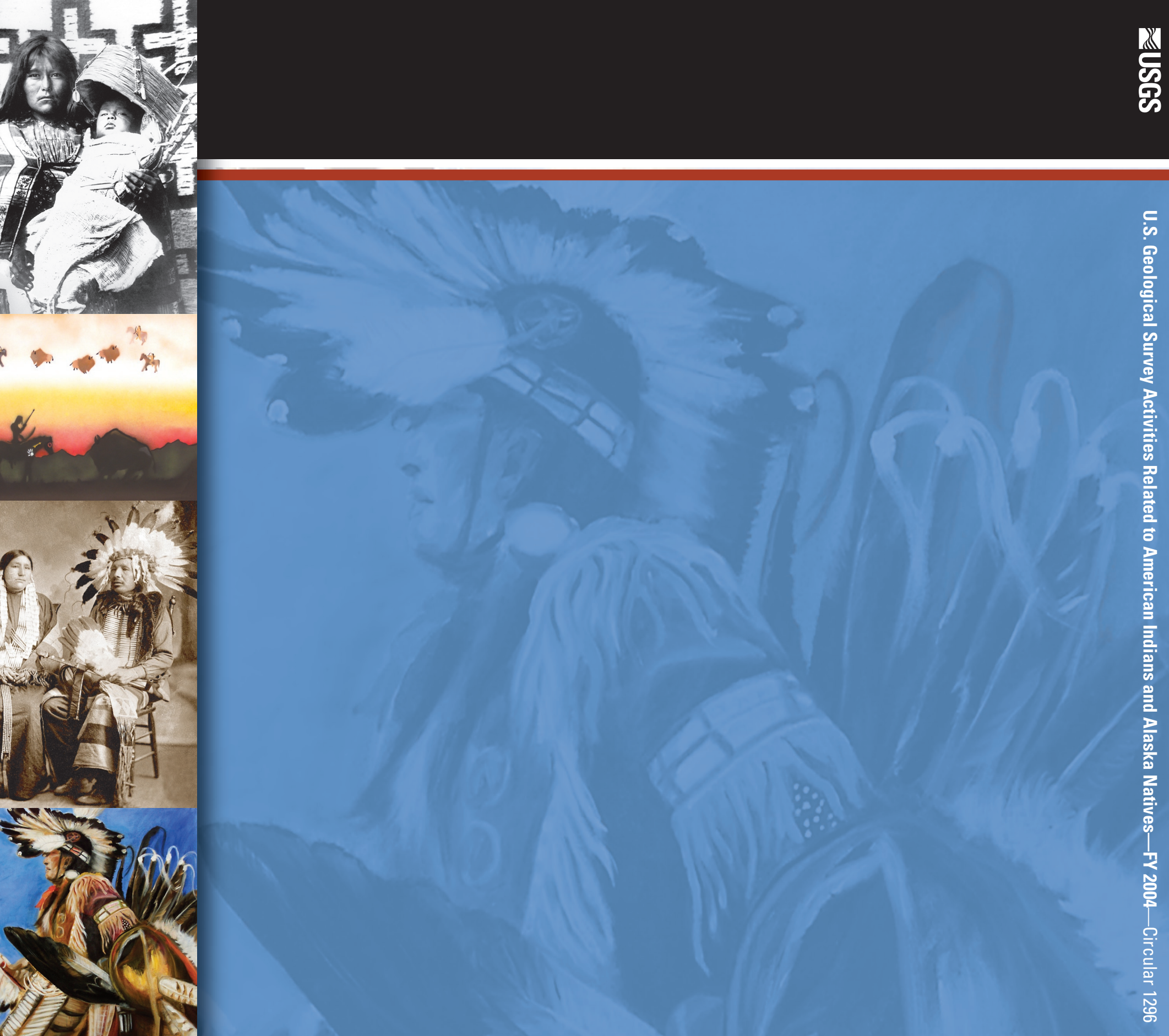

